\title{
A high-resolution diatom-based Middle and Late Holocene environmental history of the Little Belt region, Baltic Sea
}

\section{Warnock, Jonathan}

2020-01

Warnock , J , Andren , E , Juggins , S, Lewis , J , Ryves , D B , Andren , T \& Weckstrom , K 2020 , ' A high-resolution diatom-based Middle and Late Holocene environmental history of the Little Belt region, Baltic Sea ' , Boreas, vol. 49 , no. 1 , pp. 1-16 . https://doi.org/10.1111/bor.12419

http://hdl.handle.net/10138/326978

https://doi.org/10.1111/bor.12419

unspecified

acceptedVersion

Downloaded from Helda, University of Helsinki institutional repository.

This is an electronic reprint of the original article.

This reprint may differ from the original in pagination and typographic detail.

Please cite the original version. 


\section{BOREAS Aninemaional joumal of Quaternary research}

\section{A high-resolution diatom-based Middle and Late Holocene environmental history of the Little Belt region, Baltic Sea}

\begin{tabular}{|r|l|}
\hline Journal: & Boreas \\
\hline Manuscript ID & BOR-028-2019.R1 \\
\hline Manuscript Type: & Original Article \\
\hline Author: & n/a \\
\hline Complete List of Authors: & $\begin{array}{l}\text { Warnock, Jonathan; Indiana University of Pennsylvania, Geoscience } \\
\text { Andrén, Elinor; Södertörn University, School of Natural Science, } \\
\text { Technology and Environmental Studies } \\
\text { Juggins, Steve; Newcastle University, School of Geography, Politics \& } \\
\text { Sociology } \\
\text { Lewis, Jonathan; Loughborough University, Geography } \\
\text { Ryves, David; Loughborough University, Geography and Environment } \\
\text { Andrén, Thomas; Södertörn University, School of Natural Science, } \\
\text { Technology and Environmental Studies } \\
\text { Weckström, Kaarina; University of Helsinki, Ecosystems and } \\
\text { Environment }\end{array}$ \\
\hline Keywords: & $\begin{array}{l}\text { IODP Expedition 347 Site Mo059, palaeoecology, palaeoceanography, } \\
\text { salinity, trophic state, diatoms, quantitative salinity reconstruction }\end{array}$ \\
\hline
\end{tabular}




\section{A high-resolution diatom-based Middle and Late Holocene environmental history of the Little Belt \\ 2 region, Baltic Sea}

\section{Jonathan Warnock, Elinor Andrén, Steve Juggins, Jonathan Lewis, David B. Ryves, Thomas Andrén}

4 Kaarina Weckström,

5 The large-scale shifts in the salinity of the Baltic Sea over the Holocene are well understood and have

6 been comprehensively documented using sedimentary proxy records. More recent work has focused on

7 understanding how past salinity fluctuations have affected other ecological parameters (e.g. primary productivity, nutrient content) of the Baltic basin, and salinity changes over key events and over short

9 timescales are still not well understood. The International Ocean Drilling Program Expedition 347 cored

10 the Baltic basin in order to collect basin-wide environmental records through a glacial-interglacial cycle.

11 Site M0059 is located in the Little Belt between the Baltic Sea and the Atlantic Ocean. A composite splice

12 section from Site M0059 was analysed at a decadal resolution to study changes in salinity, nutrient

13 conditions and other surface water column parameters based on changes in diatom assemblages and on

14 quantitative diatom-based salinity inferences. A mesotrophic slightly brackish assemblage is seen in the

15 lowermost analysed depths, corresponding to 7,800-7,500 cal. a BP. An increase in salinity and nutrient

16 content of the water column leads into a meso-eutrophic brackish phase. The observed salinity increase

17 is rapid, lasting from 7,500 to 7,150 cal. a BP. Subsequently, the Little Belt becomes oligotrophic and is

18 dominated by tychopelagic diatoms from ca. 7,100 to ca. 3,900 cal. a BP. This interval contains some of

19 the highest salinities observed followed by diatom assemblages similar to that of the Northern Atlantic

20 Ocean, composed primarily of cosmopolitan open ocean marine diatoms. A return to tychopelagic

21 productivity is seen from 3,850 to 980 cal. a BP. Anthropogenic eutrophication is detected in the last 300

22 years of the record which intensifies in the uppermost sediments. These results represent the first

23 decadally-resolved record in the region and provide new insight into the transition to a brackish basin

24 and subsequent ecological development. 


\section{Key words}

26 IODP Expedition 347 Site M0059; palaeoecology; palaeoceanography; salinity; trophic state; diatoms;

27 quantitative salinity reconstruction

28

29 Jonathan Warnock, jwarnock@iup.edu, Department of Geoscience, Indiana University of Pennsylvania, 30 Indiana, PA 15705 USA

31 Elinor Andrén, elinor.andren@sh.se, School of Natural Science, Technology and Environmental Studies,

32 Södertörn University, SE-14189 Huddinge, Sweden

33 Steve Juggins, stephen.juggins@newcastle.ac.uk, The School of Geography, Politics and Sociology,

34 Newcastle University, NE1 7RU, United Kingdom

35 Jonathan Lewis, j.p.lewis@Iboro.ac.uk, Geography and Environment, Loughborough University,

36 Leicestershire, LE11 3TU, United Kingdom

37 David B. Ryves, d.b.ryves@lboro.ac.uk, Geography and Environment, Loughborough University,

38 Leicestershire, LE11 3TU, United Kingdom

39 Thomas Andrén, thomas.andren@sh.se, School of Natural Science, Technology and Environmental

40 Studies, Södertörn University, SE-14189 Huddinge, Sweden

41 Kaarina Weckström, kaarina.weckstrom@helsinki.fi, Ecosystems and Environment Research Programme

42 (ECRU), and Helsinki Institute of Sustainability Science, P.O. Box 65 (Viikinkaari 1), 00014 University of

43 Helsinki, Finland, and Department of Marine Geology and Glaciology, Geological Survey of Denmark and

44 Greenland (GEUS), $\varnothing$. Voldgade 10, DK-1350 Cph. K, Denmark

\section{Introduction}


46 The Baltic Sea is an important resource for the nine nations sharing its coastline. Recently, the Baltic has

47 experienced intense eutrophication, leading to harmful algal blooms (Karlson et al., 2017) and increased

48 deep-water hypoxia (Gustafsson et al., 2012; Carstensen et al., 2014; Andersen et al., 2017; van

49 Helmond et al., 2017), which have negative impacts on the ecology, recreational and economic utility of

50 the sea. In order to fully understand recent eutrophication in the Baltic Sea, past nutrient regimes must

51 be scrutinized. Furthermore, reconstructing past changes in Baltic nutrient conditions provides insight

52 into the long-term drivers of Baltic Sea ecosystems. Many previous studies have focused on

53 reconstructing the salinity history of the Baltic Sea during well-known alternating freshwater and

54 brackish water stages, which are primarily driven by glacioisostatic rebound (full reviews of the Baltic

55 Sea history can be found in; Andrén et al. 2000a; Björck, 2008; Andrén et al. 2011; Weckström et al.

56 2017). Briefly, deglaciation of the Baltic basin began c. 16,000 cal. a BP, initiating the freshwater Baltic

57 Ice Lake stage (Björck 2008; Andrén et al., 2011). Continued ice retreat opened a connection over south

58 central Sweden between the Baltic basin and the Atlantic, allowing for draining of the ice-dammed lake

59 and influx of saline water from the North Atlantic. Consequently, the partly brackish Yoldia Sea stage

60 began at c. 11,700 cal. a BP. Isostatic rebound caused a renewed separation of the Baltic basin and

61 Atlantic leading to the dammed freshwater Ancylus Lake stage, c. 10,700 cal. a BP. The Baltic's

62 connection to the Atlantic resumed at c. 9,800 cal. a BP, now in the southern part of the basin. This

63 ultimately resulted in renewed influx of saline water to the Baltic, causing a transition to the brackish

64 Littorina Sea stage, c. 8,000 cal. a BP (Andrén et al., 2000a; Berglund et al., 2005). The Littorina Sea stage

65 is further subdivided, with the Post-Littorina Sea stage beginning at c. 3,000 cal. a BP and the Recent

66 Baltic Sea state covering the last 1,000 years (Andrén et al., 2000a).

67 While the complex salinity history of the Baltic Sea has been qualitatively reconstructed

68 throughout most of the basin, there remain discussions about where and when the first marine inflows

69 occurred over the Danish Straits (Little Belt, Great Belt, Øresund), the transition areas which connect the 
70 present Baltic Sea to the North Sea. Weakly brackish conditions in the southern Baltic Sea and in

71 Swedish coastal waters have been recorded at 9,800 cal. a BP (Andrén et al., 2000a; Berglund et al.,

72 2005) and are interpreted as minor sporadic inflows via the Great Belt, which at that time functioned as

73 a calm fluvial environment (Björck 2008). In the Danish Straits no evidence for these early inflows are

74 found. The oldest marine shells in the Great Belt are dated at 8,100 cal. a BP (Bennike et al., 2004).

75 Øresund developed into a strait between 9,000-8,000 cal. a BP (Bennike et al., 2012) and in the Little

76 Belt area brackish conditions were established by ca. 8,500 cal. a BP, although the oldest marine shell

77 from the Little Belt dates to 7,700 cal. a BP (Bennike and Jensen 2011).

Diatoms, unicellular algae with opaline $\left(\mathrm{SiO}_{2}{ }^{*} \mathrm{H}_{2} \mathrm{O}\right)$ cell walls, are an ideal source of proxy data

79 for inferring ecological conditions in the Baltic Sea. Diatoms recovered from sediment cores have been

80 used to reconstruct, for example, surface water salinity (Lewis et al., 2016), water depth (Warnock et al.,

81 2017), micro- and macronutrient conditions (Cortese and Gersonde 2007; Weckström et al., 2007;

82 Andrén et al., 2017;), sea ice conditions (Armand et al., 2017) and upper water column nutrient recycling

83 (Warnock et al., 2015). Both studies evaluating the relationship between ecological and chemical

84 parameters and diatom species' distributions (e.g. Snoeijs et al. 1993-1998; Clarke et al., 2006;

85 Weckström et al., 2007; Andrén et al., 2017) and diatom-based palaeoecological investigations have

86 been published within the Baltic Sea area and associated basins (e.g. Andrén et al., 2000a,b; Witak and

87 Dunder 2007; Witkowski et al., 2009; Lewis et al., 2013; Lewis et al. 2016; Warnock et al., 2017).

In September 2013, the Integrated Ocean Drilling Program Expedition 347 cored a series of sites

89 across the Baltic basin with the goal of generating correlated, basin-wide records of Baltic Sea history.

90 Core site M0059 in the Little Belt region captured an extraordinarily high-resolution Holocene sediment

91 record (Fig. 1). A multiproxy study from this site detailed changes in salinity, precipitation and

92 temperature in the Little Belt region at centennial resolution (Kotthoff et al., 2017), and another inferred 93 seasonal hypoxia during the past 8000 years (van Helmond et al., 2017). The present study provides a 
94 decadal-resolution diatom-based assessment of ecological conditions at Site M0059 covering the past

$95 \sim 7,800$ cal. a BP with the aim to examine the fresh-brackish water transition in detail and develop

96 greater understanding of trends in surface water salinity and primary production from the Littorina Sea

97 to the present day. The rate and timing of important events can be understood in detail by generating a

98 decadally-resolved data set. Our results will be discussed in the context of the overall development of

99 the Baltic Sea basin. Specific research questions which will be addressed are; when and how did the

100 transition into the brackish-marine stage (cf. Littorina Sea) occur, when did maximum salinity occur, how

101 did the Little Belt system change during the Holocene Thermal Maximum, Neoglacial cooling and the

102 Medieval Climate Anomaly, and when are the first traces of recent eutrophication recorded in the Little

103 Belt area?

104

105 Material and Methods

\section{Regional setting}

107 The Baltic Sea Area as defined by HELCOM (1993) includes the Baltic Sea and the shallow transition zone 108 to the North Sea, the Kattegat and the Belt Sea (including Great Belt and Little Belt), which is markedly 109 influenced by the brackish water outflow from the Baltic Sea. The Baltic Sea sensu stricto is confined by 110 the shallow sill between Sweden and Denmark, the Drogden sill (8 $\mathrm{m}$ water depth) and the sill between 111 Denmark and Germany, the Darss sill (18 m water depth) (Snoeijs-Leijonmalm and Andrén, 2017). These 112 sills mark the natural biological boundary of species distribution between the more marine-influenced 113 Belt Sea and the low-salinity brackish water of the Baltic Sea. At present, the Baltic Sea consists of a 114 mixture of marine North Sea water and freshwater runoff from the drainage area four times the size of 115 the sea surface area itself (Snoeijs-Leijonmalm and Andrén, 2017). This results in a spatially extensive 116 surface water salinity gradient (in $\mathrm{g}^{-1}$ ) ranging from $\sim 12-30$ in Kattegat, $\sim 10-23$ in Belt Sea, $\sim 5-11$ in the 
117 Baltic Sea proper, 4-7 in the Bothnian Sea and 2-4 in Bothnian Bay (Snoeijs-Leijonmalm and Andrén, 118 2017).

Five cores were obtained in the Little Belt from the geotechnical research vessel Greatship Manisha at site M0059 $\left(55^{\circ} 0.29^{\prime} \mathrm{N}, 10^{\circ} 6.19^{\prime} \mathrm{E}\right)$, water depth $37.1 \mathrm{~m}$, using an advanced piston corer as 121 part of IODP Expedition 347 in September 2013 (Andrén et al., 2015a). The composite splice section, 122 sampled for this study, was generated via the Correlator software package and a composite depth scale 123 (meters composite depth; mcd) was established (Andrén et al., 2015a). Samples were collected and 124 subsampled by the on-shore science party at Marum, University of Bremen, Germany in January and 125 February 2014 with a sampling interval of $\sim 20 \mathrm{~cm}$.

The lithology at site M0059 is divided into seven lithostratigraphic units. The lowermost Unit VII 127 encountered Cretaceous limestone bedrock at $169 \mathrm{~m}$ composite depth (mcd below sea floor), Units VI128 IV (169-83 mcd) consisted of diamicton interlayered with sand and silt indicative of a succession of 129 repeated glaciations, followed by Unit III ( 83 to $53 \mathrm{mcd}$ ), interpreted as glaciolacustrine deglaciation 130 sediment deposited as varved glacial clay of unknown age (Andrén et al., 2015a;b). Unit III is erosionally 131 cut off by Unit II, a c. 2 cm upwards coarsening sandy-silty layer indicative of a rapid regression and sea132 level low stand (Andrén et al., 2015b). The uppermost unit, Unit I, consists of c. 52 m of Holocene 133 sediments and is divided into subunit Ib and la. Subunit Ib (53.57-49.37 mcd) consists of greenish gray 134 well-sorted silty clay with prominent $\mathrm{cm}$-scale laminae while subunit la $(49.37-0 \mathrm{mcd})$ is mostly 135 homogeneous black to greenish black well-sorted organic rich clay with faint millimeter-scale laminae 136 showing minor bioturbation (Andrén et al., 2015a). Sub-units la and lb are utilized for this study.

138 Dating

139 A robust radiocarbon-based age model was created using 16 fragmentary or intact bivalves which 140 resulted in a mean sedimentation rate of $6.6 \mathrm{mmyr}^{-1}$ in Sub-unit la (van Helmond et al., 2017). The age 
141 model was generated with Clam version 2.2 (Blaauw 2010) with 2000 iterations and using the Marine13

142 calibration data set (Reimer et al., 2013). A deviation $(\Delta R)$ of $-90 \pm 53$ years from the Marine13 reservoir

143 age was used, based on the mean value for $\Delta R$ for suspension and deposit feeders in three study sites

144 relatively close to Site M0059, as reported in the Marine Reservoir Correction Database

145 (http://calib.org/marine/), Map-No 1692, 1693 (Lougheed et al., 2013) and Map-No 93 (Heier-Nielsen et

146 al., 1995). The sediment surface is not assumed to be modern because of piston coring techniques. Due

147 to lack of suitable material to date, the age model is linearly extrapolated below 48.64 mcd $(\sim 7,400$ cal.

148 a BP) down to the lowermost analyzed sample at $53.12 \mathrm{mcd}$, which corresponds to an age of 7,800 cal. a 149 BP.

151 Diatoms

152 Sediment preparation and slide creation followed Warnock \& Scherer (2014). Sediment

153 subsamples were freeze-dried prior to weighing, with $\sim 0.05 \mathrm{~g}$ of sediment used per sample. Weighed

154 samples were gently crushed, using only vertical motion in a mortar and pestle, to disaggregate the

155 sediment and treated with a few $\mathrm{mL}$ each of $10 \% \mathrm{H}_{2} \mathrm{O}_{2}$ to remove organics and $10 \% \mathrm{HCl}$ to remove

156 carbonates. The treated sediment slurry, a $10 \mathrm{~mL}$ volume, was then settled through a water column in

157 a beaker with a known cross section containing a coverslip. This technique allows for the calculation of

158 absolute diatom abundance (ADA) in valves/gram dry weight of sediment $\left(\mathrm{vgdw}^{-1}\right)$. After the beaker was

159 drained, coverslips were allowed to air dry and slides were permanently fixed with Naphrax (refractive

160 index $=1.65)$. Diatoms were identified to the species level primarily following Snoeijs et al. (1993-1998),

161 with additional identifications from Witkowski et al. (2000), Cleve-Euler (1951), Fryxell \& Hasle (1972,

162 1980), Hasle (1978a, b), Hasle \& Lange (1992), Hustedt (1930), Krammer \& Lange-Bertalot (1988, 1991a,

163 199b), Muylaert \& Sabbe (1996), Mölder \& Tynni (1967-1973), Sabbe \& Vyverman (1995), Snoeijs 
164 (1992), and Tynni $(1975,1976,1978,1980)$. At least 300 valves were counted per sample at 1000x

165 magnification using Nomarski differential interference contrast and oil immersion on an Olympus BX53

166 microscope. Chaetoceros resting spores (CRS) were also counted, but not included in the 300 valve

167 count, as many spores are notoriously difficult to identify to species level and this genus covers a large

168 range of ecological conditions. The salinity-based affinities of Snoeijs et al. (1993-1998) were used to

169 categorize diatoms as freshwater (F), brackish-fresh (BF), brackish (B), brackish-marine (BM) and marine

170 (M). Snoeijs et al. (1993-1998) did not use quantitative salinity measurements in defining these five

171 categories, instead the categories are based on observations of present-day distributions of diatom

172 species in the Baltic Sea. Three exceptions are Stauroneis radissonii, which is classified by Snoeijs et al.

173 (1993-1998) as brackish-marine, Pauliella taeniata, which is classified as brackish and Fragilariopsis

174 cylindrus, which is classified as brackish-fresh. Ecological studies reveal that these diatoms are

175 associated with stratified water columns resultant from sea-ice melt and formation (Poulin \& Cardinal

176 1982; Okolodkov 1993; Armand et al. 2005; Zheng et al. 2011; Mundy et al. 2011). As such, S. radissonii,

177 P. taeniata, and F. cylindrus are placed into a sea-ice category and are not counted with the salinity

178 groups.

The diatom record was subdivided into six local diatom abundance zones (DAZ) using CONISS

180 sum of squares cluster analysis in the Tilia software package. Only diatom species with a $3 \%$ relative

181 abundance in at least one sample were used for cluster analysis. Analysis of variance (ANOVA) was used

182 to evaluate the differences between the mean values for diatom salinity affinities, absolute diatom

183 abundance (ADA), species richness, benthic to pelagic ( $\mathrm{B}: \mathrm{P})$ ratio, and CRS absolute abundance between

184 the six zones. A Tukey-Kramer pair-wise test was utilized to evaluate relationships between individual

185 DAZ. For all statistical tests performed, an $\alpha$ value of 0.05 was used. All statistical relationships were

186 evaluated using PAST v. 3.10 (Hammer et al., 2001). 
Diatom preservation was assessed using a modification of the method of Ryves et al. (2009). In

188 each sample, fifty valves of two common diatom species were classified into one of two preservation

189 stages: pristine valves (showing no sign of dissolution) and valves with signs of dissolution. This included

190 expansion of areolae, etching of the valve surface, and loss of the valve margins to dissolution. Ryves et

191 al. (2009) utilized between two and four preservation stages, representing progressive dissolution of the

192 valve face, to quantify diatom dissolution. A preservation index (F) was then calculated as a simple

193 percent of valves showing no evidence of dissolution (Ryves et al. 2001). Two robust diatom species,

194 Paralia sulcata and Cocconeis scutellum, were selected for this analysis because they were the only two

195 species present in every sample analysed. Cocconeis scutellum is an obligate benthic diatom, whereas

196 Paralia sulcata is facultatively pelagic (McQuoid and Nordberg, 2003). We argue that differences in

197 dissolution behaviour between the taxa can be interpreted in terms of taphonomic conditions

198 representative of their respective habitats, rather than intrinsic differences in robustness, as $F$ values

199 show no systematic differences until the more recent part of the record (see Results and Discussion).

200 Quantitative palaeo-salinity estimates were made using a weighted averaging partial least

201 squares (WAPLS, ter Braak and Juggins, 1993) transfer function based on a modern pan-Baltic training

202 set (210 sites) sampled during the Molten/Define projects (Andrén et al. 2007). The training set is

203 described in more detail in Lewis et al. (2013, 2016 plus supplements) where it was applied to infer

204 salinity changes at Danish coastal/marine sites. The prediction error of each WAPLS component was

205 estimated by h-block cross-validation (Burman et al. 1994) in which samples closer than a cut-off

206 distance $(h)$ from a target sample were excluded from contributing to the prediction of that sample. $h$ -

207 block cross-validation (CV) was used to allow for spatial dependency in the calibration data, which can

208 lead to underestimation of the prediction error because of pseudoreplication. The cut-off distance (h)

209 was estimated by assessing the spatial structure of the residuals of the surface sample predictions.

210 Specifically, $\mathrm{h}$ was estimated as $37 \mathrm{~km}$ using the range of a circular variogram fitted to the detrended 
211 residuals using the method described in Trachsel and Telford (2015). A randomization t-test applied to

212 h-block prediction errors (van der Voet, 1994) indicated that only the first WAPLS component was

213 significant (h-block cross-validation $\mathrm{r}^{2}=0.85, \mathrm{RMSEP}=0.46$ square-root salinity units).

214

215 Results

216 A total of 301 samples were counted at a resolution of $\sim 20 \mathrm{~cm}$ ( $\sim 30$ years, on average with a standard

217 deviation of 14; Fig. 2). Due to intense sampling of some intervals, a $20 \mathrm{~cm}$ resolution could not be used

218 throughout the entire studied section. Table 1 provides ranges and averages for diatom environmental

219 metrics, i.e. ADA, CRS abundance, the ratio of benthic to pelagic life forms (B:P) and species richness (R),

220 as well as salinity affinities for each DAZ. A total of 210 diatom species and varieties, from within 83

221 genera, were identified within the core (species with $>3 \%$ relative abundance are given in Table 2 ).

222 Branching points in the CONISS tree were used to separate six adjacent diatom assemblage zones, DAZ 1

223 - DAZ 6. ANOVA revealed significant differences between each DAZ. Results of Tukey-Kramer pairwise

224 tests of the differences between specific variables for adjacent DAZ are presented in Table 3.

225 DAZ 1 covers the period between $\sim 7,800$ to $~ 7,500$ cal a BP and is dominated by diatoms from 226 within the genera Aulacoseira (mean 38\%), Stephanodiscus (mean 17\%) and Cyclotella (mean 11\%) (Fig.

227 3) that are predominantly freshwater-affiliated and planktic (Fig. 4). Based on the diatom assemblage 228 and presence of CRS, the assemblage is not purely freshwater. Diatom preservation is poor (Fig. 6), with 229 both species used to assess preservation having the lowest recorded average percent of undissolved 230 valves (Paralia sulcata-45\%, C. scutellum - 37\%).

231 DAZ 2 covers the timespan from $\sim 7,500$ to $\sim 7,150$ cal a BP. It is comprised of a mixed 232 assemblage of all salinity preferences, dominated by brackish diatoms. Diatom salinity preferences shift 233 rapidly through this interval, estimated at $\sim 0.85 \mathrm{~g} \mathrm{~L}^{-1} /$ decade. Brackish taxa Paralia sulcata (mean 19\%), 
Cyclotella choctawhatcheeana (mean 6\%), the brackish-marine Thalassionema nitzschioides (mean 8\%)

235 and marine Hyalodiscus scoticus (mean 9\%) are the most common diatoms in this zone. Statistically

236 significant changes compared to DAZ 1 were identified with respect to $R, B: P, C R S$ and the percent of

237 freshwater, brackish, brackish-marine and marine species. Diatom preservation increases greatly in this

238 interval, with Paralia sulcata having an F value of $72 \%$ and Cocconeis scutellum having an F value of $77 \%$.

239 DAZ 3 occurs between $\sim 7,150$ and $\sim 5,500$ cal a BP. DAZ 3 is similar to DAZ 2 in that Paralia

240 sulcata (mean 41\%) and Thalassionema nitzschioides (mean 9\%) dominate. It is distinguished by a

241 decline in the marine-affiliated diatom Hyalodiscus scoticus (mean 4\%), while the other dominant

242 marine-affiliated taxa Dimeregramma minor (mean 8\%) and Shionodiscus oestrupii (nominate variety,

243 mean 6\%) display their highest abundances in the whole stratigraphy. The assemblage is primarily

244 composed of brackish and marine species. Richness (mean $=46.81)$ and $\mathrm{B}: \mathrm{P}(\mathrm{mean}=0.50)$ decline

245 significantly with respect to DAZ 2 , while ADA (mean $=6.02 * 10^{7}$ ) significantly increases. In addition,

246 statistically significant decreases in freshwater and brackish-fresh diatoms as well as increases in

247 brackish and marine diatoms are detected relative to DAZ 2. Diatom preservation decreases in this

248 interval, with F values of 66\% (Paralia sulcata) and 65\% (Cocconeis scutellum).

249 DAZ 4 extends from $\sim 5,500$ to $\sim 3,850$ cal a BP. This assemblage is mainly brackish-affiliated. The 250 highest recorded average (48\%) and absolute (72\%) abundance of Paralia sulcata is found within DAZ 4.

251 There is a statistically significant decrease in ADA (mean $=4.16^{*} 10^{7} \mathrm{vgdw}^{-1}$ ). A statistically significant

252 increase in the mean percent of brackish-affiliated diatoms and decrease in marine diatoms is also

253 detected between DAZ 3 and DAZ 4.

DAZ 5 covers the interval from $\sim 3,850$ to 1000 cal a BP. Skeletonema marinoi (mean 5\%) is

255 abundant relative to the rest of the core. Thalassionema nitzschioides (mean 14\%) increases in

256 abundance in this interval as well. Paralia sulcata (17\%), previously dominant in DAZ 3 and 4, declines in 
257 abundance within the first half of DAZ 5, and remains at lower abundance, typically $<20 \%$, throughout 258 the rest of the zone. The abundance of sea ice species, which during all the previous DAZ has been very 259 low ( 1\%), increases around 3,000 cal a BP to 3-5\% and staying at similar levels throughout the rest of 260 the core. Species richness (mean $=59.66), \mathrm{B}: \mathrm{P}($ mean $=1.05)$ and CRS abundance $\left(\right.$ mean $=1.41 * 10^{7} \mathrm{~V}$ $261 \mathrm{gdw}^{-1}$ ) reveal statistically significant increases relative to DAZ 4. Statistically significant increases in 262 freshwater, brackish-marine and marine diatoms are detected, while brackish diatoms significantly 263 decrease in abundance.

Finally, DAZ 6 spans from $\sim 1000$ cal a BP to the core top (i.e. present day). It is defined by a 265 return to abundant Paralia sulcata (mean 20\%) and decline of Skeletonema marinoi (mean 0.1\%). In 266 addition, Cyclotella choctawhatcheeana (mean 3\%) and Thalassiosira levanderi (mean 1\%) become more 267 abundant in this zone, especially within the upper meter of the core (last 200 years). Furthermore, a 268 distinct peak in Thalassiosira proschkinae (mean 20\%) is seen in the upper $0.4 \mathrm{~m}$. The only statistically 269 significant change detected among the environmental metrics relative to DAZ 5 is a decrease in the 270 percent of marine diatoms.

271 Quantitative salinity inferences

272 In terms of salinity change, there is an overall agreement between the salinity reconstruction based on 273 Snoeijs et al. (1993-1998) diatom affinities and the DI-salinities (WAPLS), despite some concern over 274 WA-based optima of individual taxa and the accuracy of salinity categorisation based on their present275 day distribution in the Baltic Sea. Both records show a clear freshwater to weakly brackish phase before $276 \sim 7,500$ cal. a BP prior to a sharp salinity increase at 7,500 cal. a BP. In the DI-record, highest salinities 277 occur between $~ 7,000-3,900$ cal. a BP, followed by a gradual decline after this date (over 1000 years). 278 Lower, but relatively stable salinities are inferred between $\sim 3000-1,000$ cal. a BP, though over this phase 279 (i.e. DAZ 5), there is some disagreement with the qualitative interpretation based on the diatom 
280 affinities. The last 1,000 years is characterised by greater fluctuation in salinity before approximately

281300 years ago, after which salinity begins to decline towards its present-day value. It is noteworthy that

282 the reconstructed value for the core surface (present day) agrees very well with the average measured 283 values in the Little Belt (15.9 \pm 0.4 for a 10-year period (2004-2014; ICES, 2017), suggesting the diatom284 based inference model for salinity used here is robust.

286 Discussion

In general, the salinity shifts identified here correspond well to those identified in Kotthoff et al. 288 (2017). The most notable exception is the lowermost analyzed portion of the core, DAZ $1(7,800-7,500$ 289 cal. a BP). This interval is interpreted as freshwater in Kotthoff et al. (2017) and van Helmond et al. 290 (2017) but is interpreted as slightly brackish here based on diatom species analysis (Fig. 3, 4). It 291 corresponds to the slightly brackish transitional stage of the Initial Littorina Sea (cf. Andrén et al., 2000a) 292 and indicates that a freshwater phase similar to the Ancylus Lake stage was not captured in this record. 293 The weakly brackish conditions are followed by a rapid increase in salinity in DAZ 2, which lasts 294 approximately 340 years. High resolution sampling allows for the timing of this transition to be captured 295 in greater detail than has been previously reported. DAZ 3 and DAZ 4 correspond to the brackish 296 Littorina Sea stage within the Baltic basin, while DAZ 5 is associated with the post-Littorina stage in the 297 Baltic Sea. DAZ 6 contains sediments representing the modern Little Belt, corresponding to the modern 298 Baltic Sea stage within the Baltic Basin.

$299 \quad$ Initial Littorina Sea

300 Based on diatom assemblage composition, DAZ 1, ( 7,800 to 7,500 cal. a BP), represents a mesotrophic, 301 slightly brackish system. The two most dominant diatom taxa, Aulacoseira islandica and Stephanodiscus 302 neoastraea, are typically found in large freshwater lakes, e.g. the Ancylus Lake (Andrén et al., 2000a; 
303 McCabe and Cyr 2006). The presence of brackish-fresh and brackish diatoms (average DI-salinity inferred

304 for DAZ-1 = $5 \mathrm{~g} \mathrm{~L}^{-1} ;$ Fig. 3) indicate that this is not a true freshwater system which post-dates the Ancylus

305 Lake stage. Poor planktonic diatom preservation implies rapid recycling of nutrients within the water

306 column in this lightly brackish environment (Fig. 6). However, the benthic diatom community is likely

307 sourced from nearby littoral regions and transported to deeper water, which will cause increased

308 dissolution of the benthic taxa. Based on ADA, diatom primary production is lower in DAZ 1 (and DAZ 2)

309 compared to the rest of the diatom record, and largely restricted to the upper water column based on

310 the low B:P ratio, as observed in other studies (e.g. Andrén et al., 2000a). However, the sedimentation

311 rate is high compared to the other DAZ (van Helmond et al., 2017) which can significantly reduce ADA.

312 Additionally, benthic diatom preservation, (assessed via Cocconeis scutellum) is worse than pelagic

313 diatom preservation. This evidence, in addition to laminated sediments (Andrén et al., 2015b), indicates

314 a strong halocline is present throughout this interval, with a freshwater pelagic lens overlying a more

315 saline lower part of the water column.

316 van Helmond et al. (2017) describe this interval as a freshwater lake, corresponding to the

317 Ancylus Lake, with well oxygenated bottom water. Conversely, Bennike and Jensen (2011) report fully

318 marine conditions in the Little Belt region at 8,000 cal. a BP. However, both of these hypotheses are

319 contradicted by a brackish water benthic diatom community (and brackish water DI-inference; Fig. 7)

320 observed here. Furthermore, the presence of laminated sediments and low rates of benthic primary

321 productivity indicate poorly oxygenated bottom water conditions. The unconformity seen from 51.68 -

32251.73 mcd (Andrén et al., 2015b), therefore, represents a sea-level low stand, with lack of deposition

323 and likely erosion, separating a glacial lake from a slightly brackish, well stratified environment rather

324 than a large freshwater lake system. The marine inflows required to create this halocline, as well as the

325 stratification itself, must contribute to the widespread hypoxia seen in the Baltic basin at this time (Zillén

326 et al., 2008). The long and narrow northern entrance into the Little Belt was probably too shallow to 
327 allow for any significant inflows of marine water at this time and it's therefore reasonable to assume

328 that marine water entered from south via Great Belt and the Kiel Bay.

Transition to a brackish system

DAZ 2, ( 7,500 to 7,150 cal. a BP), records a jump in salinity that corresponds to a previously

331 identified transgression at the southeastern Swedish Baltic coast (e.g. Yu et al., 2007). Yu et al. (2007)

332 infer a c. $4.5 \mathrm{~m}$ rapid sea level rise at 7,600 cal. a BP. This sea level rise probably resulted in a flooding of

333 the northern threshold and opened this entrance into Little Belt for the first time since the deglaciation

334 of the area. Furthermore, this transgression is observed in Mecklenburg Bay from 7,700 to 7,500 cal. a

335 BP (Kostecki et al., 2015). Decadally-resolved diatom assemblages imply a >25 $\mathrm{g} \mathrm{L}^{-1}$ rise in salinity (Fig.

336 7) over $\sim 350$ years ( 7,500 to $\sim 7,150$ cal. a BP). Changes in the diatom assemblages seen in the upper

337 samples of DAZ 1, continuing through DAZ2, also indicate an increase in nutrient concentrations.

338 Improved diatom preservation (i.e. less dissolution of valves) could imply higher (pelagic) production

339 and slower breakdown of valves (hence slower nutrient recycling), both of which would follow from an

340 increase in nutrient content of the water column. Diatom preservation remains good throughout the

341 remainder of the core, implying better conditions for preservation in the brackish system than the

342 fresher environment represented by DAZ 1. DAZ 2 is also the first zone with abundant CRS (Fig. 5).

343 Elevated abundances of Chaetoceros resting spores are typically used as indicators of high levels of

344 primary productivity, as they are formed at the termination of large seasonal blooms (Leventer et al.,

345 1996; Denis et al., 2009). However, they are also restricted to brackish/marine conditions (Snoeijs et al.,

346 1993-1998). As such, their increased abundance in DAZ 2 is not associated solely with increased primary

347 productivity, but increased salinity over the core site. Benthic primary productivity increases with

348 salinity, as shown by an increase in B:P. Furthermore, the benthic species which increase in abundance

349 are not freshwater associated. Therefore, this increase in B:P ratio is interpreted as a consequence of

350 increased salinity and an increase in suitable benthic habitats. Most of the benthic taxa increasing in DAZ 
3512 are epiphytes (e.g. Cocconeis pediculus, C.scutellum, Epithemia turgida var. westermannii), i.e. growing

352 on submerged plants, or tychoplanktonic species (e.g. Hyalodiscus scoticus and Melosira moniliformis),

353 which are often found as epiphytes leading to an interpretation that the flood resulted in large shallow

354 habitat areas available for macrophyte growth. Changing basin morphometry with water level rise is key

355 for explaining changes in habitat availability that drive diatom assemblage composition, as seen in some

356 lake studies (e.g. Stone and Fritz 2004).

\section{$357 \quad$ Littorina Sea stage}

358 The most marine phase of the Littorina Sea stage begins in DAZ 3, ( 7,150 to 5,500 cal. a BP), 359 represented by a cosmopolitan marine diatom assemblage and salinities consistently around $25 \mathrm{~g} \mathrm{~L}^{-1}$. At 360 c. 7,100 cal. a BP, sea level was still rising; e.g. Yu et al. (2007) document sea level rise culminating at 3616,500 cal. a BP. This interval, which occurs contemporary to the Holocene Thermal Maximum, contains 362 the highest salinity found in our record, therefore, sea level rise and associated flooding of the Little Belt 363 with Atlantic water drove salinity increase. Diatom assemblage data implies a return to oligotrophic 364 conditions and an increase in hydrodynamic regime, also likely driven by the influence of Atlantic water 365 at the core site. This increased mixing of the upper water column likely leads to the observed decrease 366 in diatom preservation and associated increase in nutrient recycling rates as has been observed in other 367 Holocene records (Warnock and Scherer, 2016). During DAZ 4, ( 5,500 to 3,850 cal. a BP), which is ecologically similar to DAZ 3, we infer a slight 369 decrease in primary productivity compared to the average ADA in DAZ 3 (there is no concurrent change 370 in sedimentation rates, van Helmond et al., 2017). Taken together with further declines in abundance of 371 eutrophic diatoms seen in earlier DAZ, this implies a decrease in nutrient concentrations. Brackish 372 diatoms increase clearly in DAZ 4, though the DI-salinity suggests little change until after 3,900 cal. a BP 373 (Fig. 3, 4). In Snoejs et al. (1993-1998) the brackish category consists of diatoms occurring everywhere in 
374 the Baltic, with no marked changes along the extensive salinity gradient, hence their increase does not

375 necessarily translate into a freshening of the water column. Despite the increase in brackish-tolerant

376 diatoms, DAZ 4, like DAZ 3, is still dominated by cosmopolitan marine diatoms Paralia sulcata,

377 Thalassionema nitzschioides and Shionodiscus oestrupii. A high wave energy water column is potentially

378 even more significant in the Little Belt at this time.

While the diol-index used in Kotthoff et al. (2017) (Fig. 7G) shows an overall agreement with the 380 DI-salinity, there is a clear deviation during this zone (beginning already in DAZ 3), as the diol-index 381 suggests lower salinities compared to the diatom-based quantitative inference. As the source organisms 382 behind the diol index are still uncertain, and as this index is not yet an established salinity proxy 383 (Rampen et al. 2012, 2014), it is difficult to assess what causes the inferred difference in these proxy 384 records. Given the uncertainties associated with the diol index, the diatom-inferred salinity presented 385 here likely provides a more reliable record of changes in the Baltic system relative to that of Kotthoff et 386 al. (2017).

The tychopelagic-dominated system seen in DAZ 3 and 4 is replaced with calmer water and

388 higher benthic and pelagic primary production in DAZ 5, ( 3,850 to $1000 \mathrm{cal}$. a BP). Paralia sulcata 389 declines rapidly in abundance, as has been recorded previously in the Bornholm Basin (Andrén et al., 390 2000a). It is replaced by increases in Thalassionema nitzschiodes and Skeletonema marinoi. Skeletonema 391 marinoi has been described as part of an open sea planktonic diatom assemblage in Baltic Sea cores 392 previously (Witak, 2013). The increase in abundance of Thalassionema nitzschiodes, a cosmopolitan 393 marine diatom, also indicates increased influence of North Sea waters on the Little Belt region.

394 Furthermore, CRS peaks frequently during this timeframe. Chaetoceros is also a common open ocean 395 planktonic genus. Furthermore, all of these diatoms are known to increase in populations with increased 396 nutrients. 
397

398

399

400

401

402

403

404

405

406

407

408

409

410

411

412

413

414

415

416

417

418

420 419 Holocene Thermal Maximum, and is seen as colder and wetter conditions in several proxy records (Fig.

The DI-salinity suggests a decline in salinity after $\sim 3,900$ cal. a BP and lower, relatively stable conditions up until 1,000 years BP. This decline is likely driven by an increase in freshwater input as suggested by the pollen-inferred annual precipitation reconstruction at the study site and the $\delta^{18} \mathrm{O}$ record of lacustrine carbonates from Lake Igelsjön in southern Sweden (Gustafsson and Westman, 2002;

Seppä et al., 2005; Kotthoff et al., 2017; Fig. 7). However, it is possible that both an increased input of marine water from the North Sea is occurring simultaneously with increased freshwater input due to wetter conditions(Seppä et al. 2005; Kotthoff et al. 2017; Fig. 7).

In addition, a number of benthic diatom species increase in abundance within DAZ 5, possibly in response to the inferred decrease in wave action or an increase in nutrient input due to rainier conditions. Benthic diatoms from within the genera Fragilaria, Staurosirella and Pseudostaurosira fill the available benthic niches. These diatoms have been identified as opportunistic colonizers in shallow Baltic coastal areas previously (Witkowski et al., 2009). A transition to calmer water and increased benthic primary production is further evidenced by the significant increase in the B:P ratio and species richness between zones 4 and 5. Both B:P and richness are high throughout DAZ 5, 3,850 to 980 cal. a BP. Interestingly, pelagic and benthic diatom preservation diverge in DAZ 5, which given their similarity prior to $\sim 4,000$ cal. a BP, suggests distinct differences in the taphonomy of benthic and pelagic habitats at this time. After DAZ 5, pelagic preservation increases slightly, whereas benthic preservation declines. As well as differences in nutrient utilization and recycling, this might reflect greater littoral turbulence relative to calmer open water conditions found at the cores site.,. As discussed earlier, transport of benthic species from the littoral zone also contributes to dissolution of benthic diatoms.

17 Finally, DAZ 5 marks the beginning of an increased relative abundance of sea ice diatoms (Fig 6),

18 implying a longer ice cover duration, which is consistent with the onset of Neoglacial cooling after the 
The lower portion of the DAZ 6, $5.7 \mathrm{mcd}$ to $2.1 \mathrm{mcd}$ (c. 980 to c. 300 cal. a BP), shows a return to

422 tychopelagic productivity seen in DAZ 3 and 4, implying increased wave action and mixing. This period

423 corresponds to the brackish Recent Baltic Sea stage in the Baltic Basin (e.g. Andrén et al. 2000a). The

424 quantitative DI-salinity suggests a continuation of brackish-marine conditions, punctuated by occasional

425 higher salinity events, particularly associated with high Paralia sulcata abundance.

426 Medieval Climate Anomaly

427 Contrary to some proxy-based studies from the western Baltic Sea, the Medieval Climate 428 Anomaly (MCA ca. 1000-700 cal a BP; Mann et al., 2009) does not clearly stand out as a period of 429 increased primary production in our data. Andrén et al. (2000a) identified a high primary productivity 430 event in the Bornholm basin during the MCA, while others have associated it with increased organic 431 carbon burial, warmer temperatures and reducing conditions in the Belt Sea (Kotthoff et al., 2017; van

432 Helmond et al., 2017). While we do observe a sharp spike in CRS abundance at c. 950 cal. a BP implying a 433 high primary productivity event, such events were also relatively frequent during DAZ 5.

434 Instead, our diatom data shows some signs of freshening before, during and after the MCA, 435 indicated by the moderate increase of freshwater species such as Staurosirella pinnata and S. lapponica.

436 This is in line with modelling studies from the Baltic Sea region (e.g. Schimanke et al., 2012), which

437 suggest increased precipitation and runoff in the Baltic Sea region during the time. Southern

438 Scandinavian proxy-based precipitation records vary over this timeframe, with pollen-inferred

439 precipitation from core M0059 indicating a decrease, whereas $\delta^{18} \mathrm{O}$ values from Lake Igelsjön in

440 southern Sweden indicate increased precipitation, agreeing with modelling results and our

441 reconstruction (Fig. 7).

442 Anthropogenic influence 
Upcore of this assemblage, $2.1 \mathrm{mcd}$ to the coretop (c. $300 \mathrm{cal}$. a BP to present), eutrophy-related

444 diatoms increase in abundance. Cyclotella atomus, C. choctawhacheeana, Thalassiosira proschkinae and

445 T. levanderi become more abundant in this zone and have all been associated with anthropogenic

446 disturbance in the Baltic (Andrén et al., 1999; Weckström 2006). Furthermore, a similar assemblage has

447 been identified by Andrén et al. (2000b) in the Gotland region and was associated with anthropogenic

448 eutrophication. In addition, an increase in cereal pollen is seen after 800 cal. a BP (Kotthoff et al., 2017),

449 representing the large-scale development of agriculture across the region. Therefore, we interpret this

450 assemblage to reflect substantial anthropogenic input of nutrients to the Little Belt region, primarily

451 from land use changes (e.g. conversion of land for agriculture). Nitrogen load to the Baltic Sea has

452 increased by four times since the turn of the $20^{\text {th }}$ century and phosphorus has increased by eight times

453 (Elmgren 1989), with the majority of input increasing since 1950 (Rosenberg et al., 1990; Clarke et al.,

454 2003; Clarke et al., 2006; Gustafsson et al., 2012). These conditions favour small centric diatoms, such as

455 seen here. The DI-salinity suggests that salinity declines over the last 300 years, though due to intense

456 nutrient changes and other human impact, isolating a salinity signal is difficult in the uppermost part of

457 the record. However, the true sediment water interface was not likely captured, hampering the

458 assessment of the modern diatom assemblages..

Conclusions

461 The Little Belt region has experienced salinity shifts similar to those previously observed in the

462 Baltic Sea. While the studied record does not include a freshwater phase, corresponding to the Ancylus

463 Lake stage in the Baltic proper, due to a hiatus in sedimentation, a slightly brackish interval

464 corresponding to the Initial Littorina Sea phase is detected, from 7,800 to 7,500 cal. a BP. An elevated

465 nutrient content is also detected through this interval, which continues during the rapid salinity increase 
466 from 7,500 to 7,150 cal. a BP, after which brackish conditions prevail. The maximum observed salinity, $46735 \mathrm{~g} \mathrm{~L}^{-1}$, occurs within the tychopelagic phase, from 7,100 to ca. 3,900 cal. a BP, during the Holocene 468 Climate Optimum, after which, with the onset of Neoglacial cooling a calmer hydrodynamic regime and 469 higher primary production prevail The diatom assemblages indicate a return to tychopelagic productivity 470 from 1000 cal. a BP to the coretop, corresponding to the Modern Baltic Sea phase within the Baltic basin 471 proper. This interval contains the Medieval Climate Anomaly, which does not clearly stand out in our 472 data set. The last $\sim 300$ years reveal anthropogenic eutrophication of the Little Belt region.

474 Acknowledgements

475 We would like to thank the Captain and crew of the Greatship Manisha and the British 476 Geological Survey for logistic support and providing the coring equipment; we would not be able to do 477 this work without them. A further thanks goes to the other expedition scientists. Martin Jakobsson is 478 kindly acknowledged for making the GIS map used in Fig. 1. We are grateful to our reviewers for their 479 helpful comments. TA and EA were financially supported by grant $2207 / 3.1 .1 / 2014$ provided by The 480 Foundation for Baltic and East European Studies. The data that support the findings of this study are 481 available from the corresponding author upon reasonable request.

\section{References}

483 Andersen, J. H., Carstensen, J., Conley, D. J., Dromph, K., Fleming-Lehtinen, V., Gustafsson, B. G., 484 Josefson, A. B., Norkko, A., Villnäs, A. \& Murray, C. 2017: Long-term temporal and spatial trends in 485 eutrophication status of the Baltic Sea. Biological Reviews 92, 135-149. doi: 10.1111/brv.12221

486 Andrén E., Shimmield, G. \& Brand, T. 1999: Environmental changes of the last three centuries indicated 487 by siliceous microfossil records from the southwestern Baltic Sea. The Holocene 9, 25-38. 
488 Andrén E., Andrén T. \& Sohlenius G. 2000a: The Holocene history of the southwestern Baltic Sea as

489 reflected in a sediment core from the Bornholm Basin. Boreas 29, 233-250.

490 Andrén, E., Andrén, T., \& Kunzendorf, H. 2000b: Holocene history of the Baltic Sea as a background for 491 assessing records of human impact in the sediments of the Gotland Basin. The Holocene 10, 687-702.

492 Andrén, T., Andrén, E., Berglund, B.E., \& Yu, S-Y. 2007: New insights on the Yoldia Sea low stand in the 493 Blekinge archipelago, southern Baltic Sea. GFF 129 (4), 277-285.

494 Andrén, T., Björck, S., Andrén, E., Conley, D. J., Zillén, L. \& Anjar, J. 2011: The development of the Baltic 495 Sea basin during the last 130 ka. In: The Baltic Sea Basin. Harff, J., Björck, S. \& Hoth., P. (eds) 75-98. 496 Springer.

497 Andrén, T., Jørgensen, B. B., Cotterill, C., Green, S., Andrén, E., Ash, J., Bauersachs, T., Cragg, B., Fanget, 498 A.-S., Fehr, A., Granoszewski, W., Groeneveld, J., Hardisty, D., Herrero-Bervera, E., Hyttinen, O., Jensen, 499 J. B., Johnson, S., Kenzler, M., Kotilainen, A., Kotthoff, U., Marshall, I. P. G., Martin, E., Obrochta, S., 500 Passchier, S., Quintana Krupinski, N., Riedinger, N., Slomp, C., Snowball, I., Stepanova, A., Strano, S., 501 Torti, A., Warnock, J., Xiao, N. \& Zhang, R. 2015a: Site M0059. In Andrén, T., Jørgensen, B. B., Cotterill, 502 C., Green, S. \& the Expedition 347 Scientists, Proceedings of the IODP 347: College Station, TX 503 (Integrated Ocean Drilling Program). doi:10.2204/iodp.proc.347.105.2015

504 Andrén, T., Jørgensen, B.B., Cotterill, C., Green, S. \& the IODP expedition 347 scientific party. $2015 b$.

505 IODP expedition 347: Baltic Sea basin paleoenvironment and biosphere. Scientific Drilling 20, 1-12. 506 doi:10.5194/sd-20-1-2015

507 Andrén, E., Telford, R J., \& Jonsson, P. 2017: Reconstructing the history of eutrophication and 508 quantifying total nitrogen reference conditions in Bothnian Sea coastal waters. Estuarine, Coastal and 509 Shelf Science 198, 320-328. 
510 Antonsson, K., \& Seppä, H. 2007: Holocene temperatures in Bohuslän, southwest Sweden: a quantitative 511 reconstruction from fossil pollen data. Boreas 36, 400-410.

512 Armand, L. K., Crosta, X., Romero, O. \& Pichon, J.-J. 2005: The biogeography of major diatom taxa in 513 Southern Ocean sediments: 1. Sea ice related species. Palaeogeography, Palaeoclimatology, 514 Palaeoecology 223, 93-126.

515 Armand, L., Ferry, A., \& Leventer, A. 2017: Advances in palaeo sea ice estimation. In: Sea ice Third 516 Edition. D.N. Thomas, ed. John Wiley \& Sons, Ltd.

517 Bennike, O., Andreasen, M.S., Jenson, J.B., Moros, M., \& Noe-Nygaard, N. 2012: Early Holocene sea-level 518 changes in Øresund, southern Scandinavia. Geological Survey of Denmark and Greenland Bulletin 26, 2951932.

520 Bennike, O., \& Jensen, J.B. 2011: Postglacial, relative shore-level changes in the Lillebælt, Denmark.

521 Geological Survey of Denmark and Greenland Bulletin 23, 37-40.

522 Bennike, O., Jensen, J.B., Lemke, W., Kuijpers, A., \& Lomholt, S. 2004: Late- and postglacial history of the 523 Great Belt, Denmark. Boreas 33, 18-33.

524 Berglund, B. E., Sandgren, P., Barnekow, L., Hannon, G., Jiang, H., Skog, G. \& Yu, S. 2005: Early Holocene 525 history of the Baltic Sea, as reflected in coastal sediments in Blekinge, southeastern Sweden. Quaternary 526 International 130, 111-139.

527 Björck, S. 2008: The late Quaternary development of the Baltic Sea basin. In: The BACC Author Team 528 (eds) Assessment of climate change for the Baltic Sea Basin. 377 pp. Springer, Berlin, Heidelberg.

529 Blaauw, M. 2010: Methods and code for "classical" age-modelling of radiocarbon sequences. Quaternary 530 Geochronology 5, 5512-5518. 
531 Brown, K.J., Seppä, H., Schoups, G., Fausto, R., Rasmussen, P., \& Birks, H.J.B. 2012: A spatio-temporal

532 reconstruction of Holocene temperature change in southern Scandinavia. The Holocene 22, 165-177.

533 Burman, P., Chow, E. \& Nolan, D. 1994. A cross-validatory method for dependent data. Biometrika, 81, $534 \quad 351-358$.

535 Carstensen, J., Andersen, J. H., Gustafsson, B. G. \& Conley, D. J. 2014: Deoxygenation of the Baltic Sea 536 during the last century. Proceedings of the National Academy of Sciences 111, 5628-5633.

537 Christensen, C., 2001: Coastal settlement and sea level change in the Stone Age., In: Jensen, O.L., 538 Sørensen, S.A., Hansen, K.M. (Eds.), Denmarks Hunting Stone Age - status and perspectives, Hoersholm 539 Egns Museum, pp. 183-193.

540 Clarke A., Juggins S. \& Conley D. 2003: A 150-year reconstruction of the history of coastal eutrophication 541 in Roskilde Fjord, Denmark. Marine Pollution Bulletin 46, 1615-1618.

542 Clarke, A.L., Weckström, K., Conley, D.J., Anderson, N.J., Adser, F., Andrén, E., de Jonge, V.N., Ellegaard, 543 M., Juggins, S., Kauppila, P., Korhola, A., Reuss, N., Telford, R.J., \& Vaalgamaa, S. 2006: Long-term trends 544 in eutrophication and nutrients in the coastal zone. Limnology \& Oceanography 51, 385-397.

545 Clemmensen, L.B., Murray, A.S., \& Nielsen, L. 2012: Quantitative constraints on the sea-level fall that 546 terminated the Littorina Sea Stage, southern Scandinavia. Quaternary Science Reviews 40, 54-63.

547 Cleve-Euler, A. 1951: Die Diatomeen von Schweden und Finland. 163 pp. Kungliga Svenska 548 Vetenskapsakademiens Handlingar Fjärde Serien, 2.

549 Cortese, G., \& Gersonde, R. 2007: Morphometric variability in the diatom Fragilariopsis kerguelensis: 550 Implications for Southern Ocean paleoceanography. Earth and Planetary Science Letters 257, 526-544. 
551 Denis, D., Crosta, X., Schmidt, S., Carson, D.S., Ganeshram, R.S., Renssen, H., Crespin, J., Ther, O., Billy, I.,

552 \& Gireadeau, J. 2009: Holocene productivity changes of Adélie Land (East Antarctica). Paleoceanography

553 24. doi: 10.1029/2008PA001689.

554 Elmgren, R., 1989: Man's impact on the ecosystem of the Baltic Sea: energy flows today and at the turn 555 of the century. Ambio 18, 326-332.

556 Fryxell, G. A., \& Hasle, G. R. 1972: Thalassiosira eccentrica (Ehrenb.) Cleve, T. symmetrica sp. nov., and 557 some related centric diatoms. Journal of Phycology 8, 297-317.

558 Fryxell, G. A. \& Hasle, G. R. 1980: The marine diatom Thalassiosira oestrupii: structure, taxonomy and 559 distribution. American Journal of Botany 67, 804-814.

560 Gustafsson, B.G., Schenk, F., Blenckner, T., Eilola, K., Meier, H.E.M., Müller-Karulis, B., Neumann, T., 561 Ruoho-Airola, T., Savchuk, O.P., \& Zorita, E. 2012: Reconstructing the Development of Baltic Sea 562 Eutrophication 1850-2006. Ambio 41, 534-548.

563 Gustafsson, B. G. \& Westman, P. 2002: On the causes of salinity variations in the Baltic Sea during the 564 last 8500 years. Paleocenography 17, 1-14.

565 Hammer, ̌̌., Harper, D. A. T. \& Ryan, P. D. 2001: PAST: Paleontological statistics software package for 566 education and data analysis. Palaeontologia Electronica 4, 9pp.

567 Hasle, G.R. \& Lange, C.B. 1992: Morphology and distribution of Coscinodiscus species from the Oslofjord, 568 Norway, and the Skagerrak, North Atlantic. Diatom Research 7 (1), 37-68.

569 Hasle, G. R. 1978a: Some freshwater and brackish water species of the diatom genus Thalassiosira Cleve. $570 \quad$ Phycologia 17, 263-292. 
571 Hasle, G. R. 1978b: Some Thalassiosira species with one central process (Bacillariophyceae). Norwegian

572 Journal of Botany 25, 77-110.

573 Heier-Nielsen, S., Heinemeir, J., Nielsen, H.L., Rud, N., 1995. Recent reservoir ages for Danish fjords and 574 marine waters. Radiocarbon 37, 875-882.

575 Hustedt, F. 1930: Die Kieselalgen Deutschlands, Österreichs und der Schweiz: unter Berücksichtigung der 576 übrigen Länder Europas sowie der angrenzenden Meeresgebiete (Vol. 1 and 2). 920 pp. In Rabenhorst, L. 577 (Ed.), Kryptogamen-Flora von Deutschland, Österreich und der Schweiz: Leipzig (Akad. Verlag).

578 ICES: Hydrochemistry, CTD and Bottle data portal, ICES, Copenhagen, 2017.

579 Karlson, B., Eilola, K., Johansson, J., Linders, J., Mohlin, M., Wranne, A.W., \& Wåhlström, I. 2017:

580 Distribution of cyanobacterial blooms in the Baltic Sea. In: Proença, L.A.O and Hallengraeff, G.M. (eds).

581 Marine and Fresh-Water Harmful Algae. Proceedings of the $17^{\text {th }}$ International Conference on Harmful

582 Algae. International Society for the Study of Harmful Algae.

583 Kostecki, R., Janczak-Kostecka, B., Endler, M., \& Moros, M. 2015: The evolution of the Mecklenburg Bay 584 environment in the Holocene in light of multidisciplinary investigations of the sediment cores.

585 Quaternary International 386, 226-238.

586 Kotthoff, U., Groeneveld, J., Ash, J.L., Fanget, A.-S., Krupinski, N.Q., Peyron, O., Stepanova, A., Warnock, 587 J., van Helmond, N.A.G.M., Passey, B.H., Clausen, O.R., Bennike, O., Andrén, E., Granoszewski, W., 588 Andrén, T., Filipsson, H.L., Seidenkrantz, M.-S., Slomp, C.P., \& Bauersachs, T. 2017: Reconstructing 589 Holocene temperature and salinity variations in the western Baltic Sea region: a multi-proxy comparison 590 from the Little Belt (IODP Expedition 347, Site M0059). Biogeosciences 14 (23), 5607-5632. doi:

$591 \quad 10.5194 /$ bg-14-5607-2017 
592 Krammer, K., \& Lange-Bertalot, H. 1988: Bacillariophyceae, Part 2. Bacillariaceae, Epithemiaceae,

593 Surirellaceae. 611 pp. In Ettl, H., Gerloff, J., Heynig, H., \& Mollenhauer, D. (Eds.), Süßwaserflora von

594 Mitteleuropa (Vol. 2/2): Stuttgart, Germany (Gustav Fischer Verlag).

595 Krammer, K., \& Lange-Bertalot, H. 1991a: Bacillariophyceae, Part 3. Centrales, Fragilariaceae,

596 Eunotiaceae. 598 pp. In Ettl, H., Gerloff, J., Heynig, H., \& Mollenhauer, D. (Eds.), Süßwaserflora von

597 Mitteleuropa (Vol. 2/3): Stuttgart, Germany (Gustav Fischer Verlag).

598 Krammer, K., \& Lange-Bertalot, H. 1991b: Bacillariophyceae, Part 4. Achnantaceae. 468 pp. In Ettl, H.,

599 Gärtner, J.G., Gerloff, J., Heynig, H., \& Mollenhauer, D. (Eds.), Süßwaserflora von Mitteleuropa (Vol. 2/4):

600 Stuttgart, Germany (Gustav Fischer Verlag).

601 Leventer, A. and Dunbar, R.B. 1996. Factors influencing the distribution of diatoms and other algae in 602 the Ross Sea. Journal of Geophysical Research 101 (8), 18489-18500.

603 Lewis, J.P., Ryves, D.B., Rasmussen, P., Knudsen, K.L., Petersen, K.S., Olsen, J., Leng, M.J., Kristensen, P., 604 McGowan, S., Phillipsen, B., 2013: Environmental change in the Limfjord, Denmark (ca. 7,500e1500 cal 605 yrs BP): a multiproxy study. Quaternary Science Reviews 78, 126-140.

606 Lewis, J.P., Ryves, D.B., Rasmussen, P., Olsen, J., Knudsen, K.-L., Andersen S.H., Weckström, K., Clarke, 607 A.L., Andrén, E., \& Juggins, S. 2016: The shellfish enigma across the Mesolithic-Neolithic transition in 608 southern Scandinavia. Quaternary Science Reviews 151, 315-320.

609 Lougheed, B.C., Filipsson, H.L., Snowball, I., 2013. Large spatial variations in coastal ${ }^{14} \mathrm{C}$ reservoir age - a 610 case study from the Baltic Sea. Clim. Past 9, 1015-1028.

611 Mann, M.E., Zhang, Z., Rutherford, S., Bradley, R.S., Hughes, M.K., Shindell, D., Ammann, C., Faluvegi, G., 612 \& Ni, Fenbiao. 2009: Global signatures and dynamical origins of the Little Ice Age and Medieval Climate 613 Anomaly. Science 326 (5957), 1256-1260. 
614 McCabe, S. \& Cyr, H. 2006: Environmental variability influences the structure of benthic algal

615 communities in an oligotrophic lake. Oikos 115, 197-206.

616 McQuoid, M.R. \& Nordberg, K. 2003: The diatom Paralia sulcata as an environmental indicator species in 617 coastal sediments. Estuarine, Coastal and Shelf Science 56 (2), 339-354.

618 Mölder, K. \& Tynni, R. 1967: Über Finnlands rezente und subfossile Diatomeen, Bulletin of the Geological 619 Society of Finland 39, 199-217.

620 Mölder, K. \& Tynni, R. 1968: Über Finnlands rezente und subfossile Diatomeen, II. Bulletin of the 621 Geological Society of Finland 40, 151-170.

622 Mölder, K. \& Tynni, R. 1969: Über Finnlands rezente und subfossile Diatomeen, III. Bulletin of the 623 Geological Society of Finland 41, 235-251.

624 Mölder, K. \& Tynni, R. 1970: Über Finnlands rezente und subfossile Diatomeen, IV. Bulletin of the 625 Geological Society of Finland 42, 129-144.

626 Mölder, K. \& Tynni, R. 1971: Über Finnlands rezente und subfossile Diatomeen, V. Bulletin of the 627 Geological Society of Finland 43, 203-220.

628 Mölder, K. \& Tynni, R. 1972: Über Finnlands rezente und subfossile Diatomeen, VI. Bulletin of the 629 Geological Society of Finland 44, 141-149.

630 Mölder, K. \& Tynni, R. 1973: Über Finnlands rezente und subfossile Diatomeen, VII. Bulletin of the 631 Geological Society of Finland 45, 159-179.

632 Mundy, C. J., Gosselin, M., Ehn, J. K., Belzile, C., Poulin, M., Alou, E., Roy, S., Hop, H., Lessard, S., 633 Papakyriakou, T. N., Barber, D. G. \& Stewart, J. 2011: Characteristics of two distinct high-light acclimated 634 algal communities during advanced stages of sea ice melt. Polar Biology 34, 1869-1886. 
635 Muylaert, K. \& Sabbe, K. 1996: The diatom genus Thalassiosira (Bacillariophyta) in the estuaries of the

636 Schelde (Belgium/The Netherlands) and the Elbe (Germany). Botanica Marina 39, 103-115.

637 Okolodkov, Y. B. 1993: A checklist of algal species found in the East Siberian Sea in May 1987. Polar 638 Biology 13, 7-11.

639 Poulin, M. \& Cardinal, A. 1982: Sea ice diatoms from Manitounuk Sound, southeastern Hudson Bay 640 (Quebec, Canada). I. Family Naviculaceae. Canadian Journal of Botany 60, 1263-1278.

641 Rampen, S.W., Willmott, V., Kim, J.-H., Uliana, E., Mollenhauer, G., Schefuß, E., Sinninghe Damsté, J.S. \&

642 Schouten, S., 2012. Long chain 1,13- and 1,15-diols as a potential proxy for palaeotemperature 643 reconstruction. Geochimica et Cosmochimica Acta 84, 204-216.

644 Rampen, S.W., Willmott, V., Kim, J.-H., Rodrigo-Gámiz, M., Uliana, E., Mollenhauer, G., Schefuß, E., 645 Sinninghe Damsté, J.S. \& Schouten, S. 2014: Evaluation of long chain 1,14-alkyl diols in marine sediments 646 as indicators for upwelling and temperature. Organic Geochemistry 76, 39-47.

647 Reimer, P.J., Bard, E., Bayliss, A., Beck, J.W., Blackwell, P.G., Bronk Ramsey, C., Buck, C.E., Cheng, H., 648 Edwards, R.L., Friedrich, M., Grootes, P.M., Guilderson, T.P., Haflidason, H., Hajdas, I., Hatté, C., Heaton, 649 T.J., Hoffmann, D.L., Hogg, A.G., Hughen, K.A., Kaiser, K.F., Kromer, B., Manning, S.W., Niu, M., Reimer, 650 R.W., Richards, D.A., Scott, E.M., Southon, J.R., Staff, R.A., Turney, C.S.M., \& van der Plicht, J. 2013: 651 IntCal13 and Marine13 radiocarbon age calibration curves 0-50,000 years cal BP. Radiocarbon 55, 18696521887.

653 Rosenberg, R., Elmgren, R., Fleisher, S., Jonsson, P., Persson, G. \& Dahlin, H. 1990: Marine eutrophication 654 case studies in Sweden. Ambio 19 (3), 102-108. 
655 Ryves, D.B., Battarbee, R.W., \& Fritz, S.C. 2009: The dilemma of disappearing diatoms: Incorporating

656 diatom dissolution data into palaeoenvironmental modelling and reconstruction. Quaternary Science

657 Reviews 28, 120-135.

658 Ryves, D.B., Juggins, J., Fritz, S.C. \& Battarbee, R.W. 2001: Experimental diatom dissolution and the

659 quantification of microfossil preservation in sediments. Palaeogeography, Palaeoclimatology,

660 Palaeoecology 172: 99-113.

661 Sabbe, K. \& Vyverman, W. 1995: Taxonomy, morphology and ecology of some widespread

662 representatives of the diatom genus Opephora. European Journal of Phycology 30, 235-249.

663 Schimanke, S., Meier, H.E.M., Kjellström, E., Strandberg, G., \& Hordoir, R. 2012. The climate in the Baltic

664 Sea region during the last millennium simulated with a regional climate model. Climates of the Past 8,

$665 \quad 1419-1433$.

666 Seppä, H., Hammarlund, D., \& Antonsson, K., 2005. Low-frequency and high-frequency changes in

667 temperature and effective humidity during the Holocene in south-central Sweden: implicatons for

668 atmospheric and oceanic forcings of climate. Climate Dynamics 25, 285-297.

669 Snoeijs, P. 1992: Studies in the Tabularia fasciculata complex. Diatom Research 7, 313-344.

670 Snoeijs, P., Vilbaste, S., Potapova, M., Kasperoviciene, J. \& Balashova, J. (Eds.), 1993-1998.

671 Intercalibration and Distribution of Diatom Species in the Baltic Sea (Vol. 1-5): Uppsala, Sweden (Opulus

672 Press).

673 Snoeijs-Leijonmalm, P. \& Andrén, E. 2017. Why is the Baltic Sea so special for organisms to live in?

674 Biological Oceanography of the Baltic Sea. In: Snoeijs-Leijonmalm, P., Schubert, H. \& Radziejewska, T.

675 (eds). Springer, Dordrecht, 23- $84 \mathrm{pp}$. 
676

677 paleolimnological interpretation of planktic : benthic ratios. Limnology \& Oceanography 49, 1540-1548.

678 ter Braak, C.J.F. \& Juggins, S. 1993. Weighted Averaging Partial Least-Squares Regression (WA-PLS) - an

679 Improved Method for Reconstructing Environmental Variables from Species Assemblages.

680 Hydrobiologia, 269, 485-502.

681 Trachsel, M. \& Telford, R.J. 2016. Technical Note: Estimating unbiased transfer-function performances in 682 spatially structured environments. Climate of the Past 12, 1215-1223.

683 Tynni, R. 1975: Über Finnlands rezente und subfossile Diatomeen, VIII. 274 pp. Bulletin of the Geological 684 Society of Finland.

685 Tynni, R. 1976: Über Finnlands rezente und subfossile Diatomeen, IX. 284 pp. Bulletin of the Geological 686 Society of Finland.

687 Tynni, R. 1978: Über Finnlands rezente und subfossile Diatomeen, X. 296 pp. Bulletin of the Geological 688 Society of Finland.

689 Tynni, R. 1980: Über Finnlands rezente und subfossile Diatomeen, XI. 312 pp. Bulletin of the Geological 690 Society of Finland.Van Helmond, N.A.G.M, Krupinski, N.A., Lougheed, B.C., Obrochta, S.P., Andrén, T., 691 and Slomp, C.P. 2017. Seasonal hypoxia was a natural feature of the coastal zone in the Little Belt, 692 Denmark, during the past 8 ka. Marine Geology, 387, 45-57.

693 van der Voet, H. 1994. Comparing the predictive accuracy of models using a simple randomization test. 694 Chemometrics and Intelligent Laboratory Systems 25, 313-323.

695 van Helmond, N.A.G.M., Quintana Krupinski, N.B., Lougheed, B.C., Obrochta, S.P., Andrén, T., \& Slomp, 696 C.P. 2017: Seasonal hypoxia was a natural feature of the coastal zone in the Little Belt, Denmark, during 697 the past 8 ka. Marine Geology 387; 45-57. http://dx.doi.org/10.1016/j.margeo.2017.03.008 
698 Warnock, J. P., \& Scherer, R. P. 2014: A revised method for determining the absolute abundance of

699 diatoms. Journal of Paleolimnology. DOI 10.1007/s10933-014-9808-0

700 Warnock, J.P., \& Scherer, R.P. 2016: Increased diatom dissolution in Prydz Bay, East Antarctica linked to 701 inception of the Prydz Bay gyre. Diatom Research doi: 10.1080/0269249X.2016.1182075

702 Warnock, J.P., Scherer, R.P. \& Konfirst, M.A. 2015: A record of Pleistocene diatom preservation in the 703 Amundsen Sea, West Antarctica with possible implications on silica leakage. Marine Micropaleontology $704117,40-45$.

705 Warnock, J.P., Bauersachs, T., Kotthoff, U., Brandt, H.-T. \& Andrén, E. 2017: Holocene environmental 706 history of the Ångermanälven Estuary, northern Baltic Sea. Boreas. doi: 10.1111/bor.12281

707 Weckström, K., Lewis, J.P., Andrén, E., Ellegaard, M., Rasmussen, P., Ryves, D.B. and Telford, R. (2017)

708 The Baltic Sea - one of the largest brackish water systems in the world. In Applications of

709 paleoenvironmental techniques in estuarine studies (Eds. K. Weckström, K. Saunders, P. Gell and G.

710 Skilbeck) Developments in Palaeoenvironmental Research Series. Springer, pp. 615-662.

711 Weckström, K., Korhola, A. \& Weckström, J. 2007: Impacts of eutrophication on diatom life forms and 712 species richness in the coastal waters of the Baltic Sea. AMBIO: A Journal of the Human Environment 36, $713 \quad 155-160$.

714 Weckström, K. 2006: Assessing recent eutrophication in coastal waters of the Gulf of Finland (Baltic Sea) 715 using subfossil diatoms. Journal of Paleolimnology 35, 571-592.

716 Witak, M. 2013: Diatom biofacies in the SW Gulf of Gdańsk and the Vistula Lagoon (the southern Baltic 717 Sea) as indicators of the basin evolution in the Middle and Late Holocene. International Journal of 718 Oceanography and Hydrobiology 42 (1), 70-88. 
719 Witak, M. \& Dunder, J. 2007: Holocene diatom biostratigraphy of the SW Gulf of Gdańsk, Southern Baltic 720 Sea (part II). Oceanological and Hydrobiological Studies 36, 3-20.

721 Witkowski, A., Cedro, B., Kierzek, A. \& Baranowski, D. 2009: Diatoms as a proxy in reconstructing 722 Holocene environmental changes in the south-western Baltic Sea: the lower Rega River Valley 723 sedimentary record. Hydrobiologia 631, 115-172.

724 Witkowski, A., Lange-Bertalot, H. \& Metzeltin, D. 2000: Diatom flora of marine coasts (Vol. 1). 925

725 pp. In Lange-Bertalot, H. (Ed.), Iconographia Diatomologica (Vol. 7): Annotated Diatom Micrographs726 Diversity-Taxonomy-Identification: Königstein, Germany (Koeltz Scientific Books).

727 Yu, S-Y., Berglund, B., Sandgren, P., \& Lambeck, K. 2007: Evidence for a rapid sea-level rise 7600 yr ago. 728 Geology $35(10), 891-894$.

729 Zheng, S., Wang, G., Zhang, F., Cai, M. \& He, J. 2011: Dominant diatom species in the Canadian Basin in 730 summer 2003, a reported serious melting season. Polar Record 47, 244-261.

731 Zillén, L., D. J. Conley, T. Andrén, E. Andrén, and S. Björck. 2008. Past occurrences of hypoxia in 732 the Baltic Sea and role of climate variability, environmental change and human impact. Earth733 Science Reviews 91: 77-92.

734

735 The data that support the findings of this study are available from the corresponding author 736 upon reasonable request. 
740

741

742

743

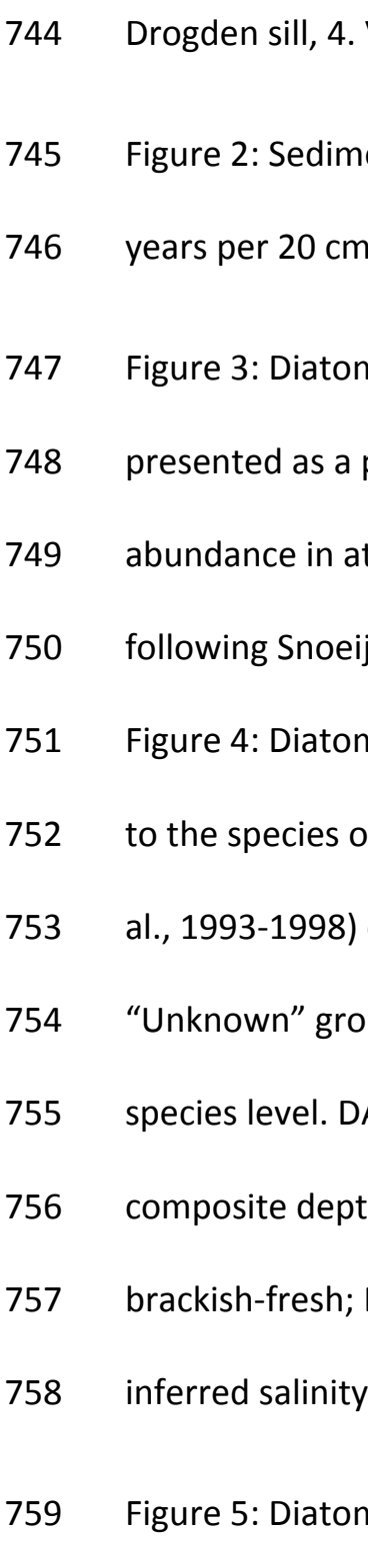

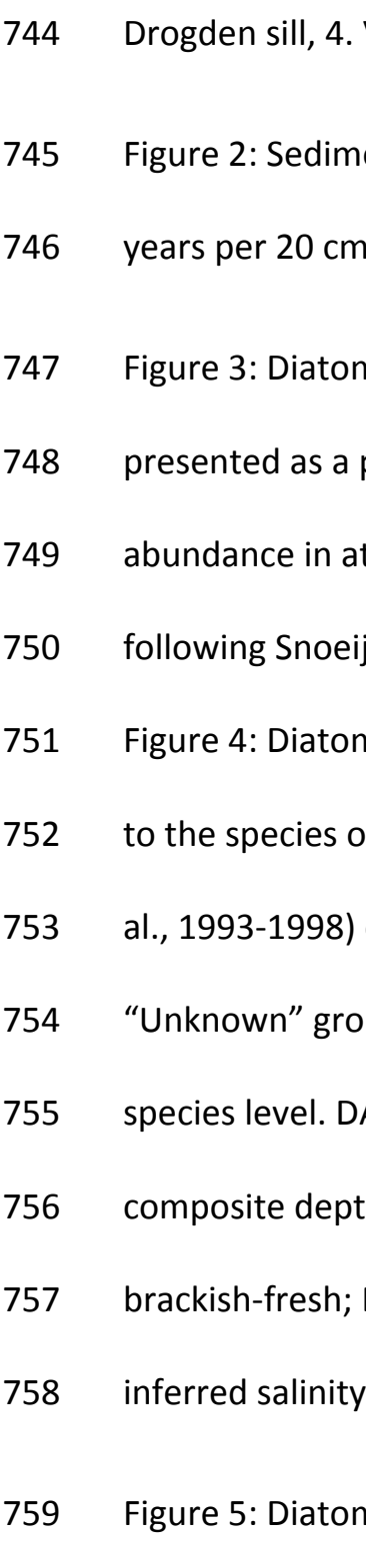

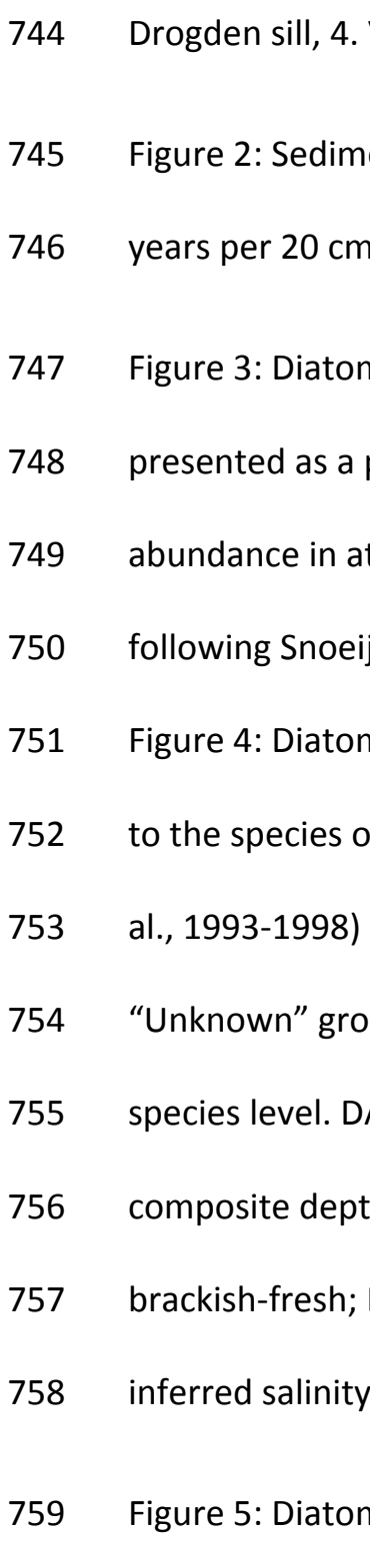

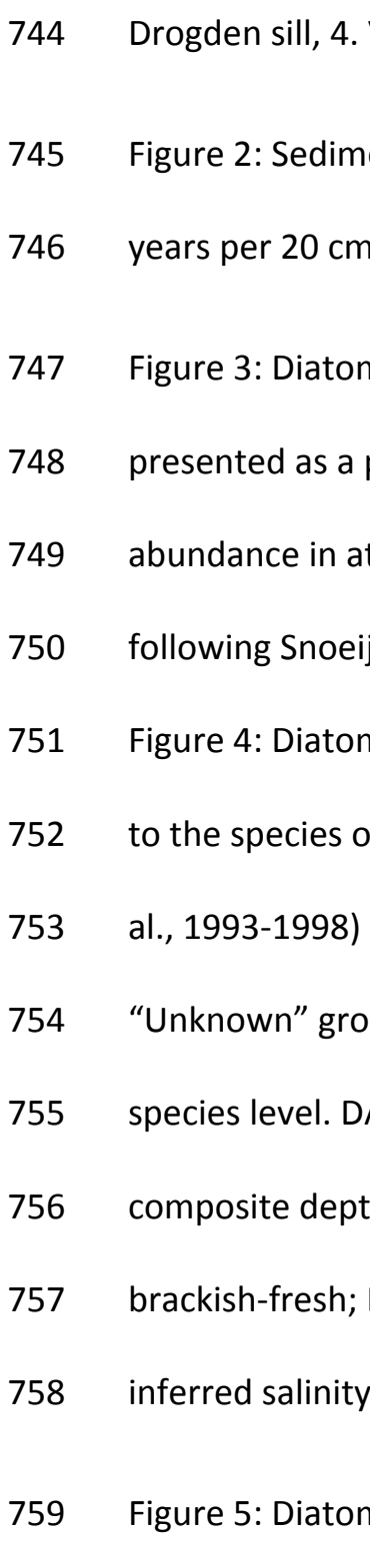

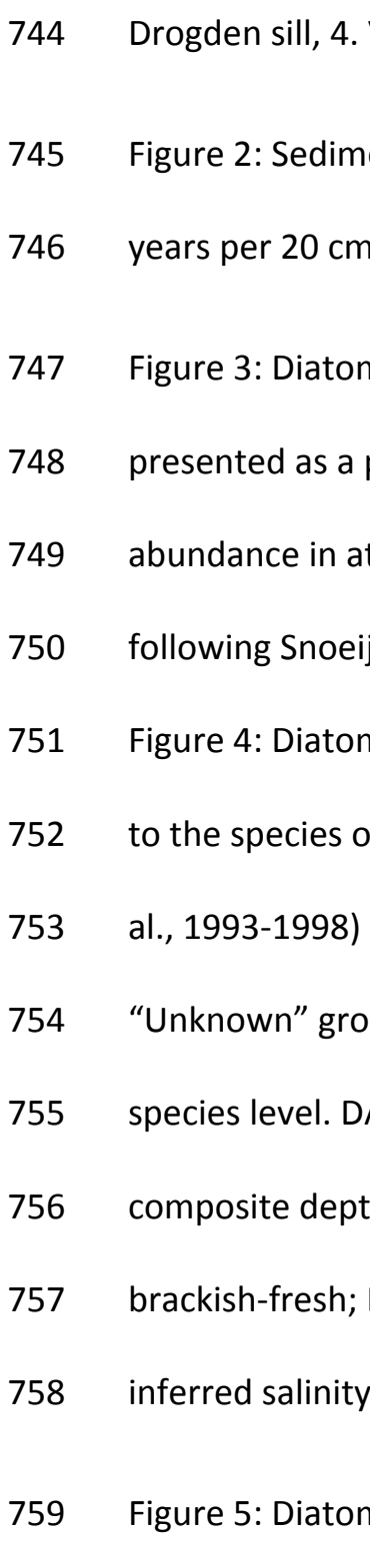

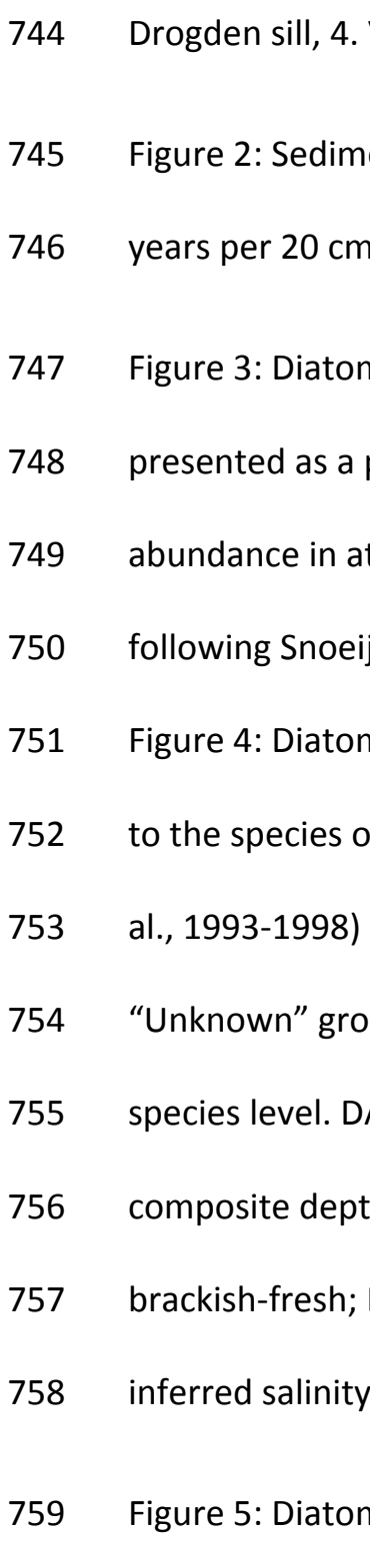

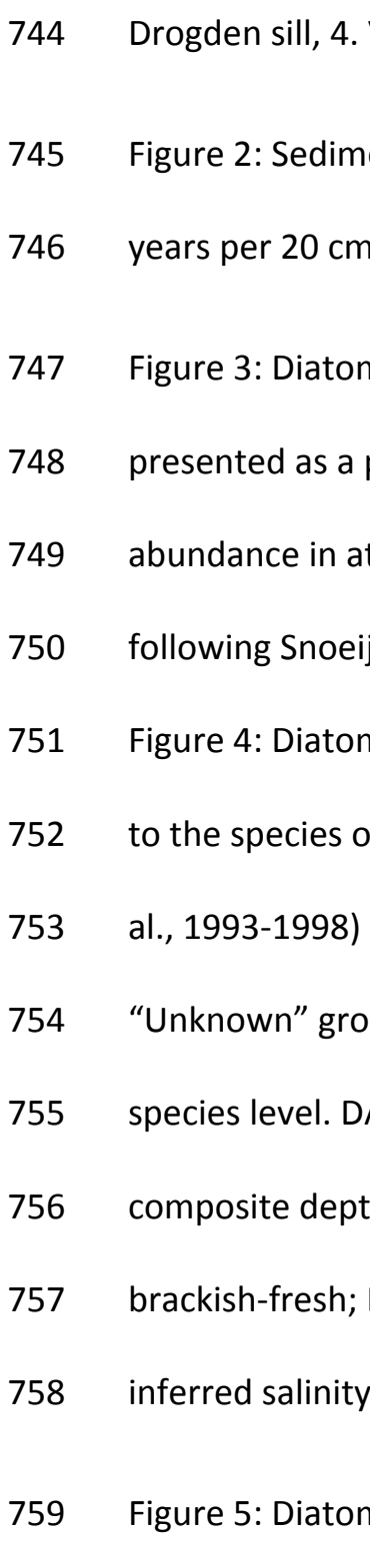

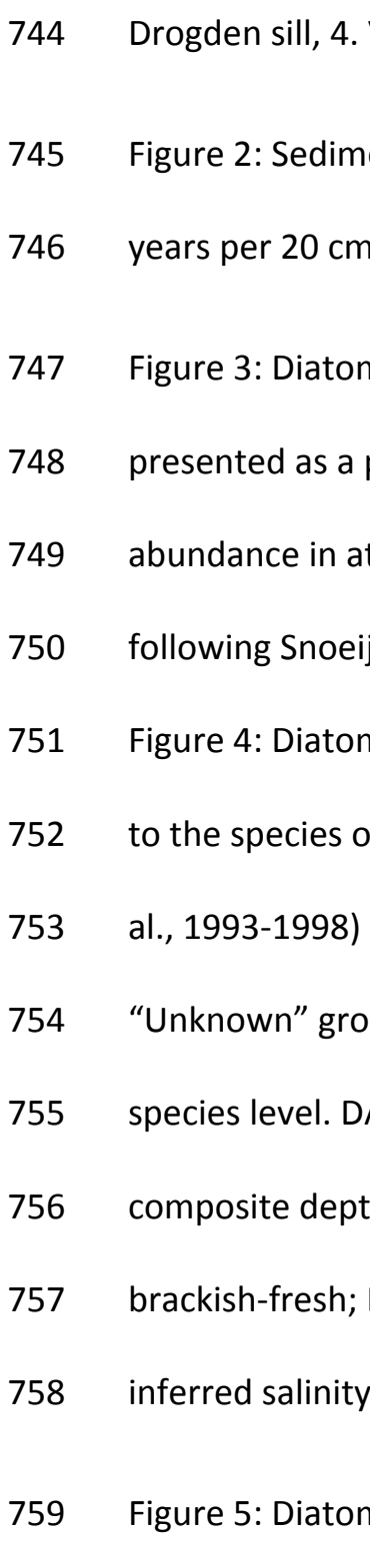

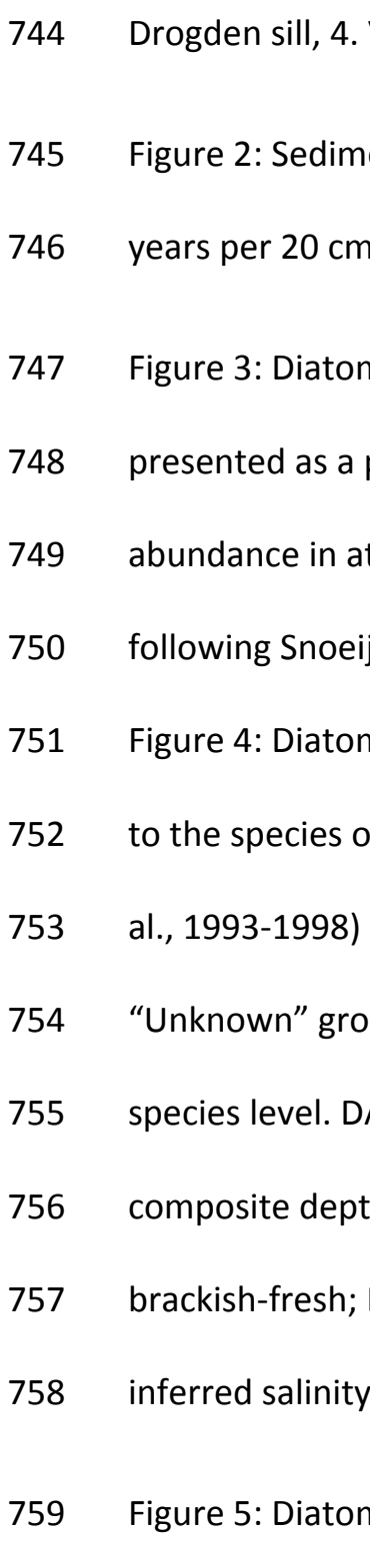

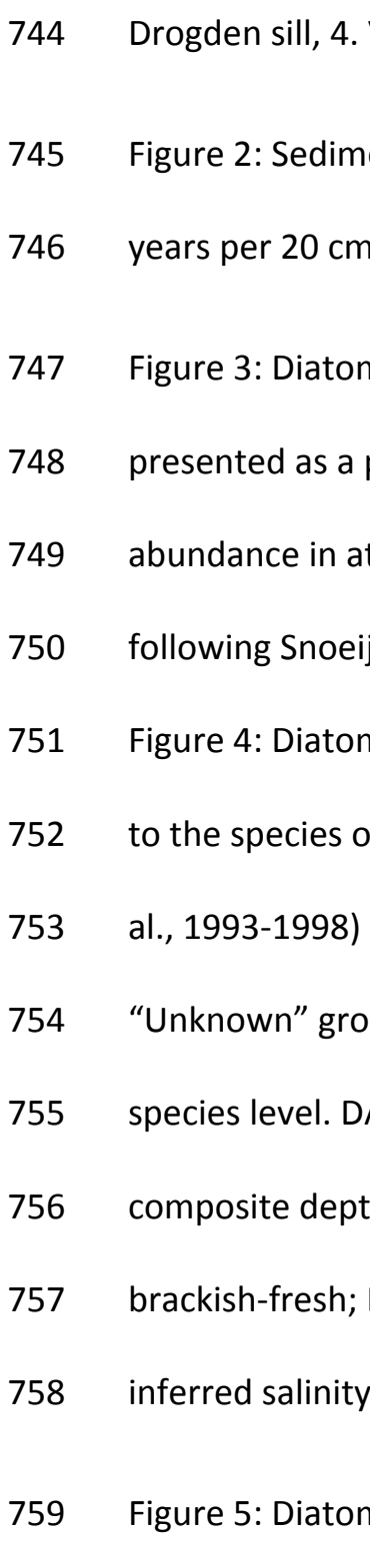

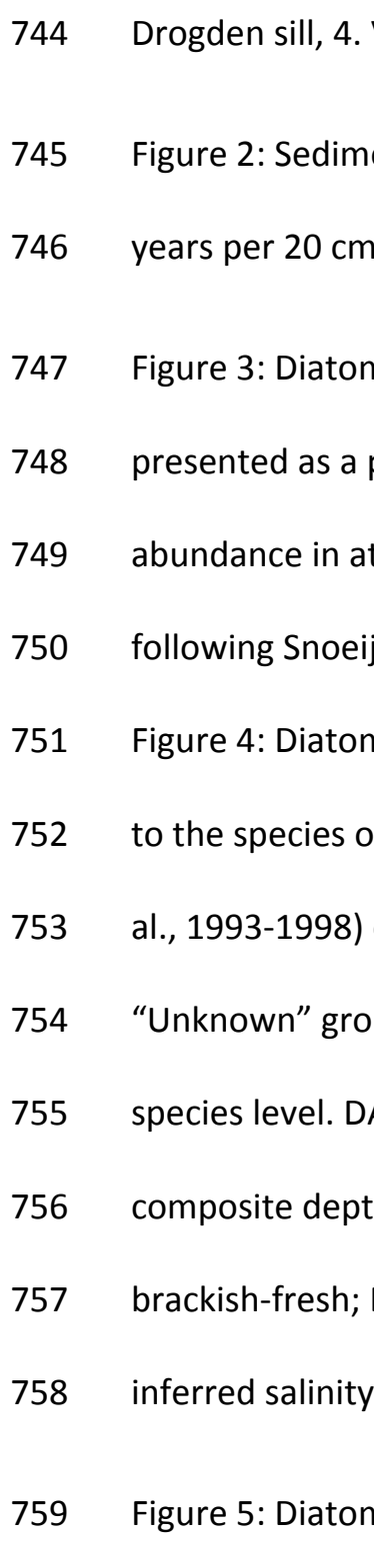

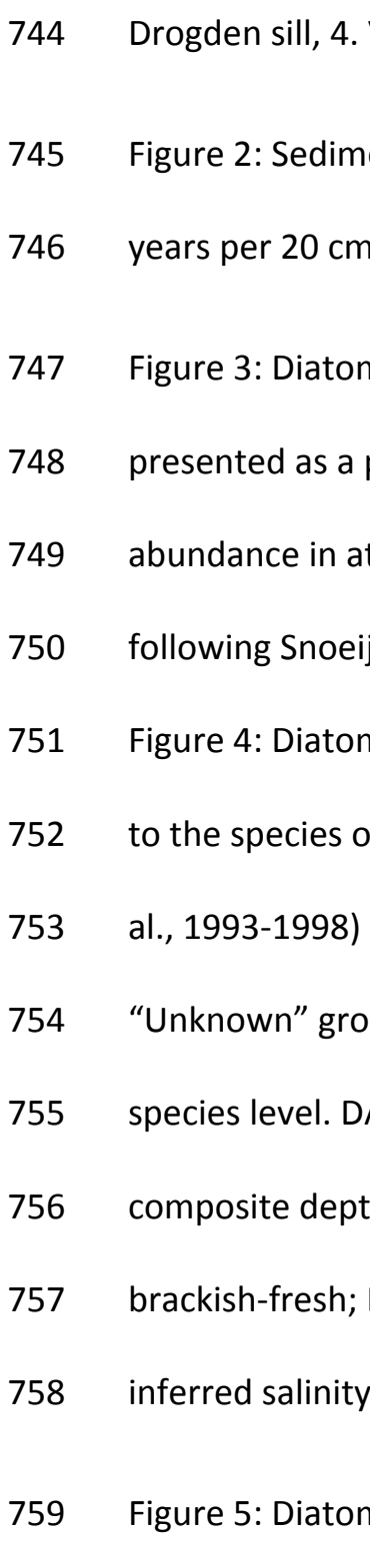

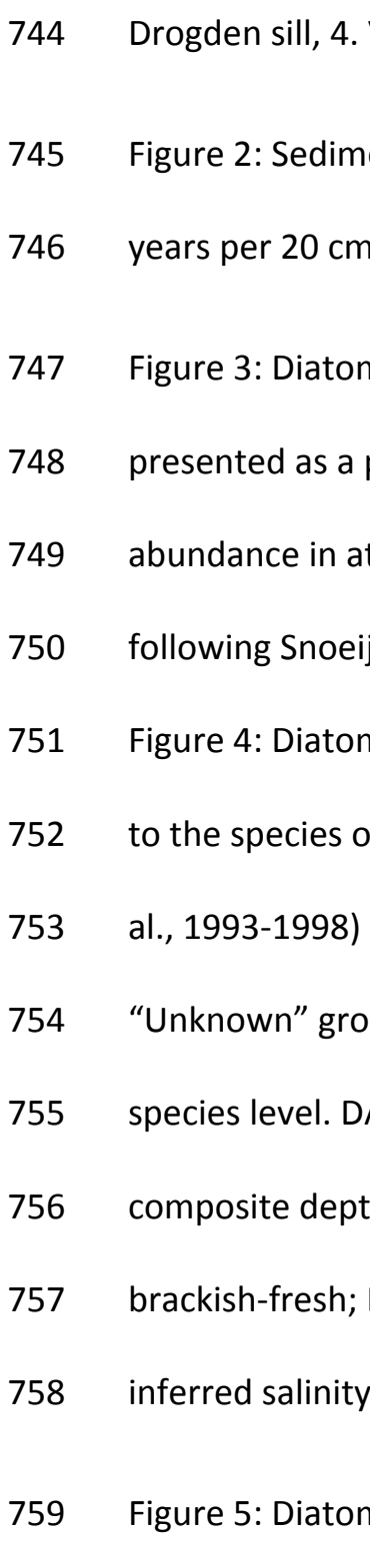

757

758 inferred salinity in $\mathrm{g} \mathrm{L}^{-1}$ includes the $\mathrm{p}=0.95$ confidence interval.

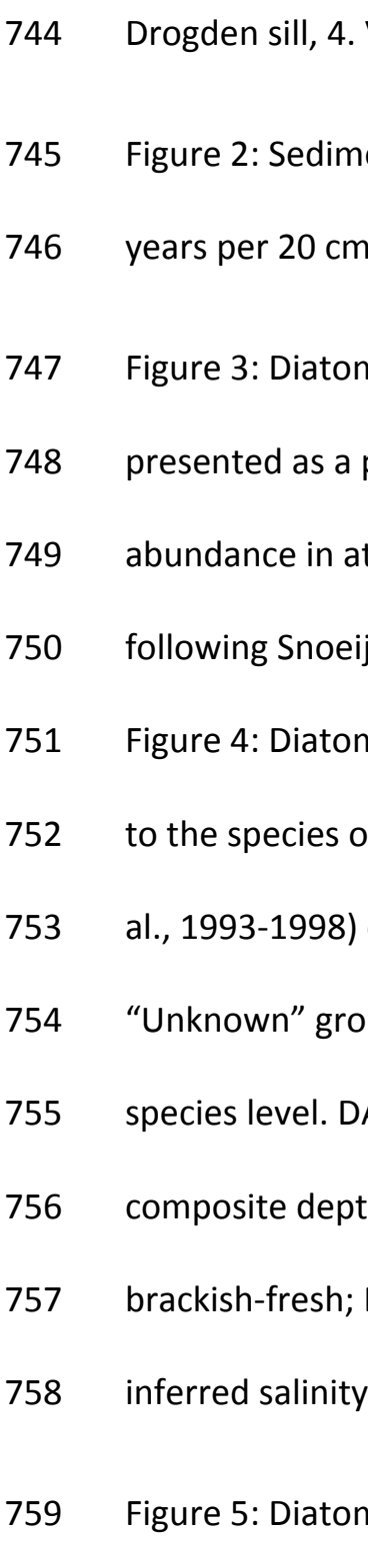

7


Figure 6: Diatom preservation indices within core M0059 Units 1a and 1b. Diatom preservation (as valve

764 dissolution) was quantitatively assessed using two species, Cocconeis scutellum and Paralia sulcata (see

765 Methods). Higher values (\%) represent better diatom preservation.

766 Figure 7: Comparison of the core M0059 data presented here with other site data (from Kotthoff et al., 767 2017) and regional parameters. A. Mean pollen-inferred annual temperature from M0059 (Kotthoff et 768 al., 2017) and Lake Trehörningen, SE Sweden (Antonsson and Seppä, 2007). B. Mean January and July 769 temperature from Denmark (Brown et al., 2012). HTM = Holocene Thermal Maximum, MCA = Medieval 770 Climate Anomaly. C. Mean coldest and warmest month temperatures inferred from pollen and D.

771 summer surface water temperatures reconstructed from LDI and TEX 86 (L) biomarkers from site M0059

772 (Kotthoff et al., 2017). E. Proxies for precipitation/wetness including pollen-inferred precipitation from 773 M0059 and oxygen isotope analysis $\left(\delta^{18} \mathrm{O}\right)$ of lacustrine carbonates from Lake Igelsjön (Seppä et al., 774 2005). F. Sea-level change from three nearby sites; Vedbæk, Sealand, Denmark (Øresund; Christensen, 775 2001), Anholt in the Central Kattegat (Clemmensen et al., 2012) and Blekinge, SE Sweden (Berglund et 776 al., 2005). G-H. Salinity proxies for M0059. G. diatom-inferred salinity presented here and Diol index 777 from Kotthoff et al. (2017). H. Diatom salinity affinities based on the Baltic Marine Biologists 778 classification system (Snoeijs et al., 1993-1998). DAZ = Diatom assemblage zone.

\section{Table Captions}

780 Table 1: This table provides the means (A) and ranges (B) of all computed diatom ecological metrics.

781 Abbreviations are as follows: ADA - absolute diatom abundance; CRS - Chaetoceros resting spore 782 absolute abundance; $v$ gdw ${ }^{-1}$ - valves per gram dry weight; $\mathrm{R}$ - richness; $\mathrm{B}: \mathrm{P}$ - Benthic to pelagic ratio; $\mathrm{F}$ 783 - freshwater; BF - brackish-fresh; B - brackish, BM - brackish-marine; M - marine; SI - sea ice. 
784 Table 2: Relative abundances of diatom species. The relative abundances (\%) for all species which have 785 an abundance of at least $3 \%$ in at least one sample are provided. Abbreviations follow table 1. In 786 addition, $\mathrm{P}$ - pelagic and B - benthic in the Lifeform column.

787 Table 3: This table provides the results of Tukey-Kramer pairwise statistical tests. "+" represents a 788 statistically significant change $(\mathrm{p} \leq 0.05)$ comparing adjacent diatom abundance zones, whereas “_“ 789 represents no significant change. Abbreviations follow Table 1. 


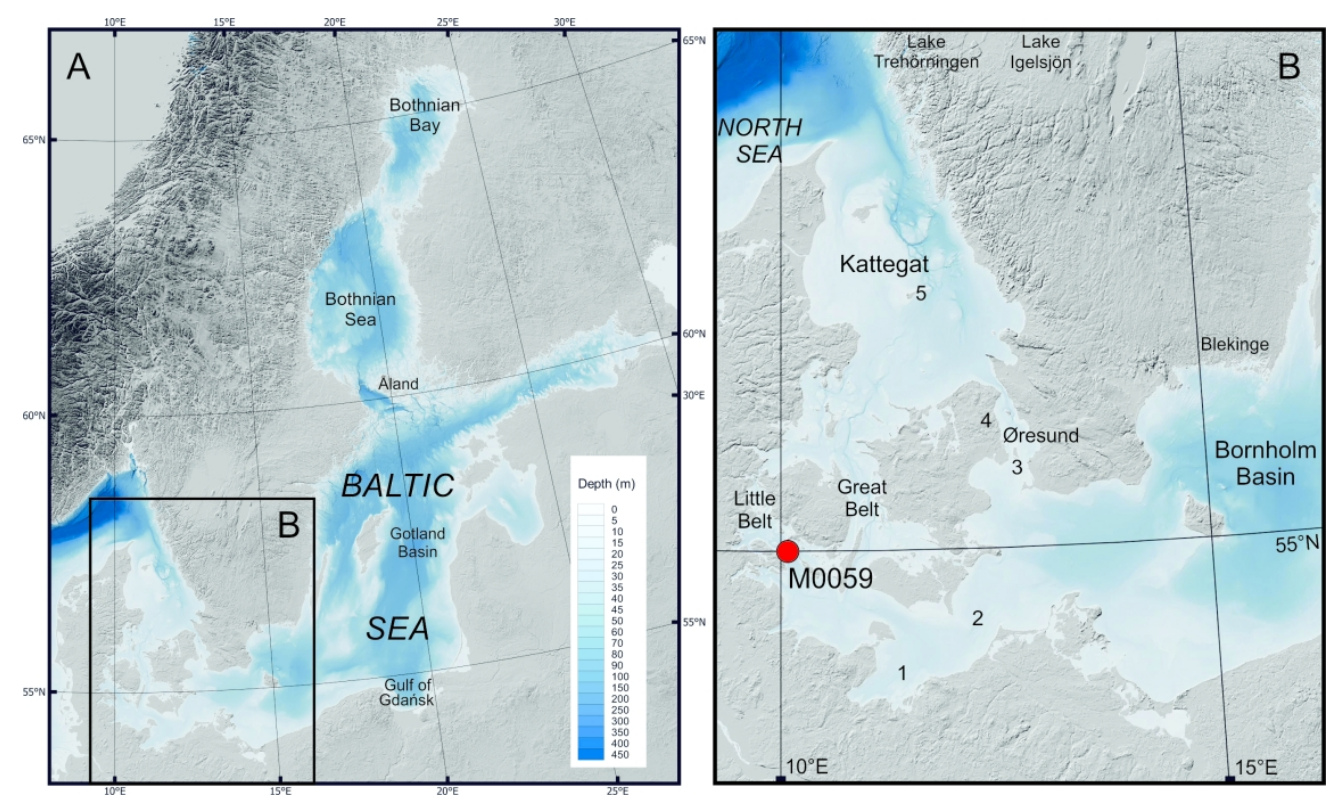

$231 \times 138 \mathrm{~mm}(300 \times 300 \mathrm{DPI})$ 


\section{M0059 sedimentationrates}

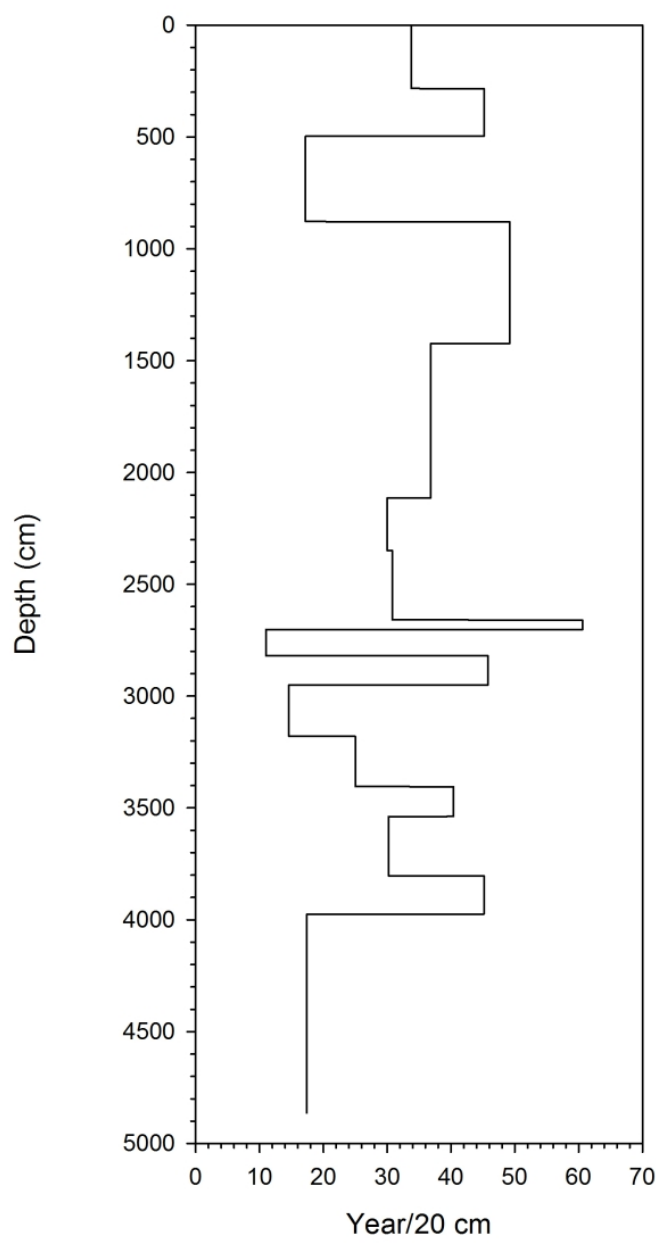

$214 \times 279 m m(300 \times 300$ DPI $)$ 


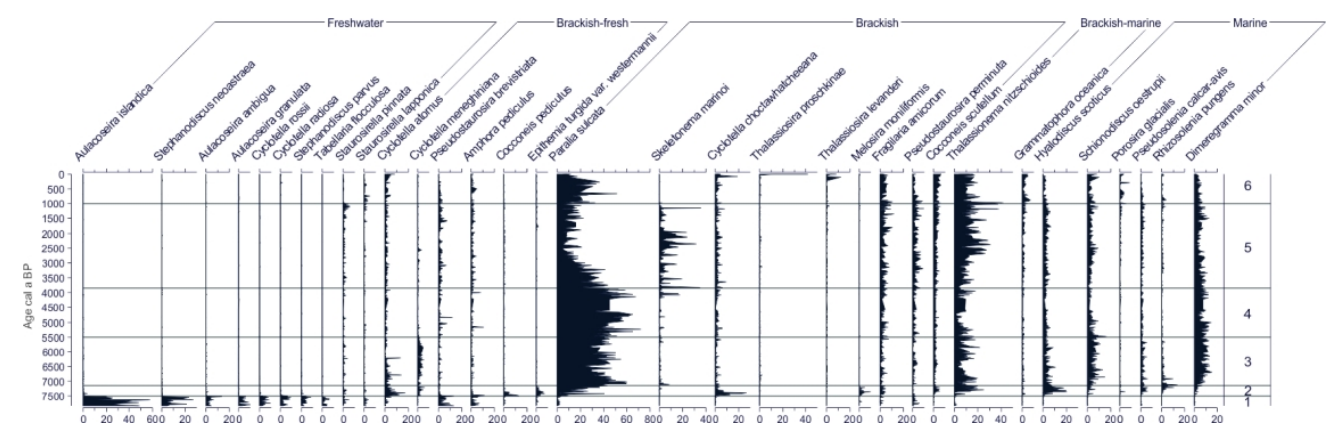

1

2

3

5

6

7

8

10

11

12

13

14

15

16

17

18

19

20

21

23

24

25

26

27

28

29

30

31

32

33

34

35

36

37

38

39

40

41

42

43

44

45

46

47

48

49

50

51

52

53

54

55

56

57

58

59

60

14
15
16
17
18
19
20
21

22

Boreas \\ Page 39 of 117}




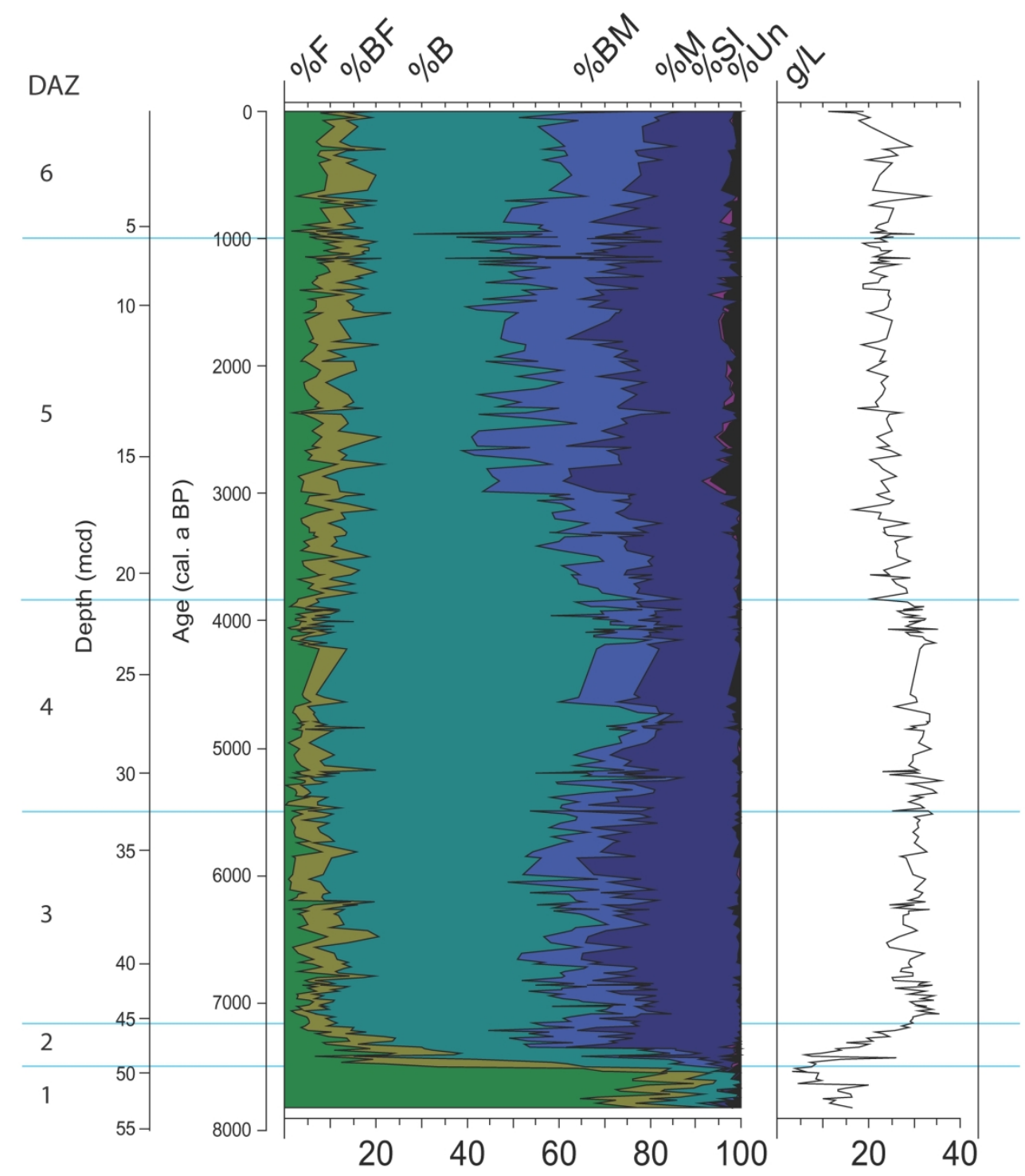

$254 \times 304 \mathrm{~mm}(300 \times 300 \mathrm{DPI})$ 


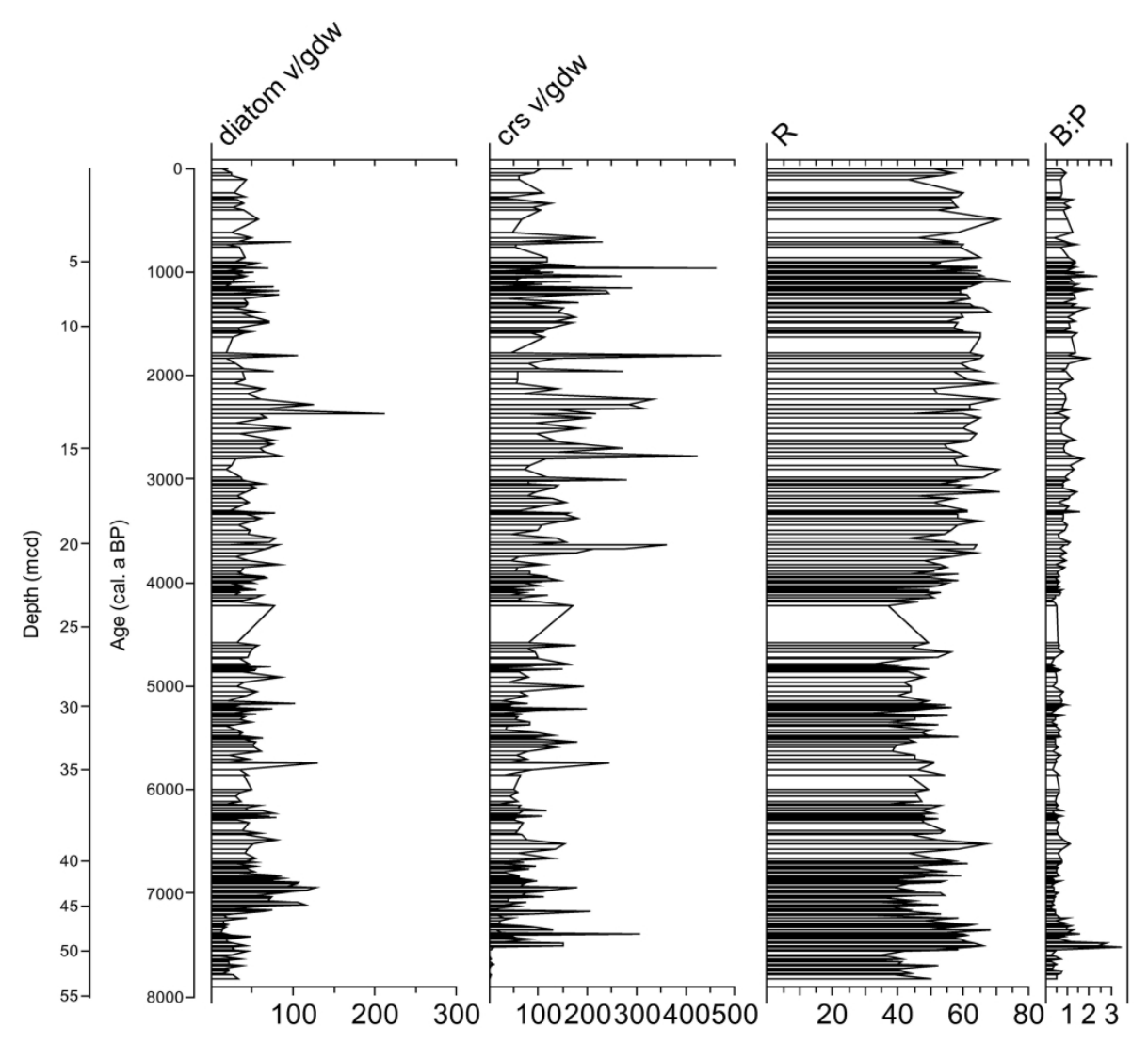

$215 \times 279 \mathrm{~mm}(300 \times 300 \mathrm{DPI})$ 


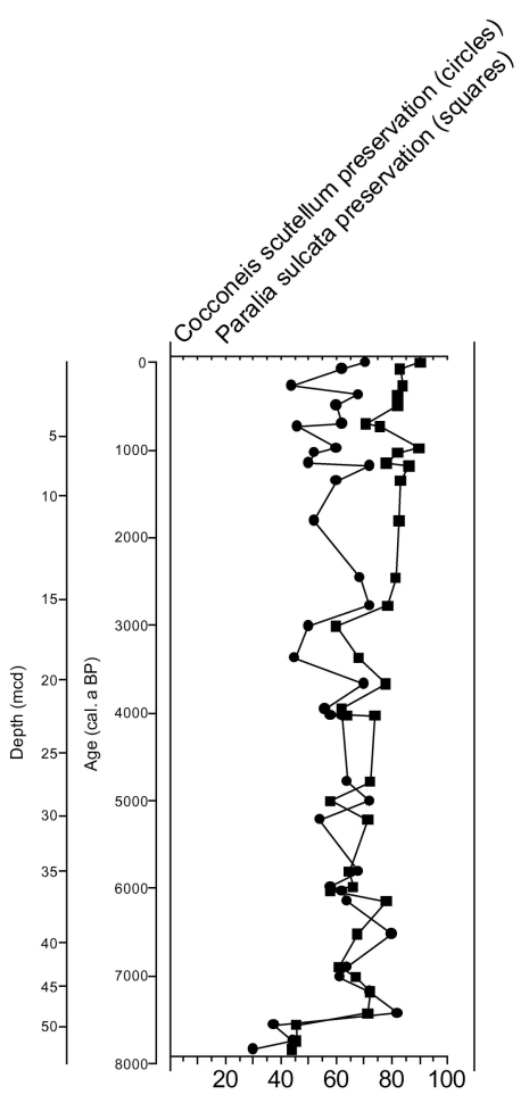

$215 \times 279 \mathrm{~mm}(300 \times 300 \mathrm{DPI})$ 


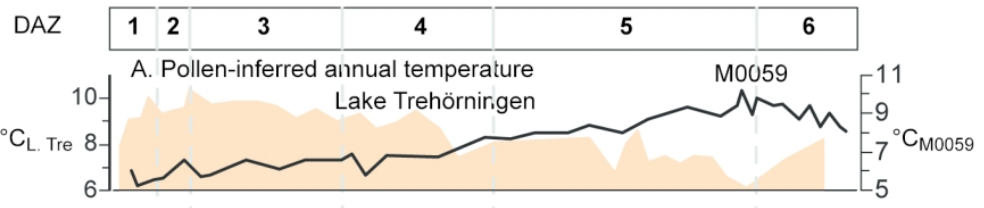

B. Mean January (blue) and July (red) Temperature: Denmark

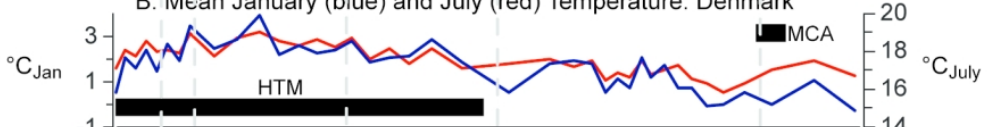

C. Me!an coldest (bl te) and warmest (red) month temperat ure

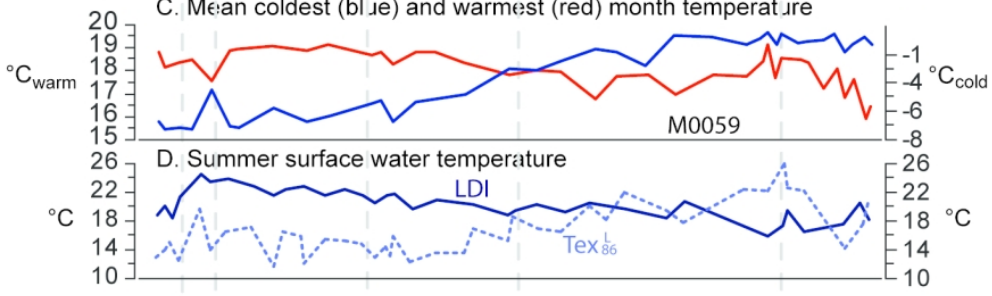

E. Precipitation prosies Pollen-inferred precipitation (M0059)
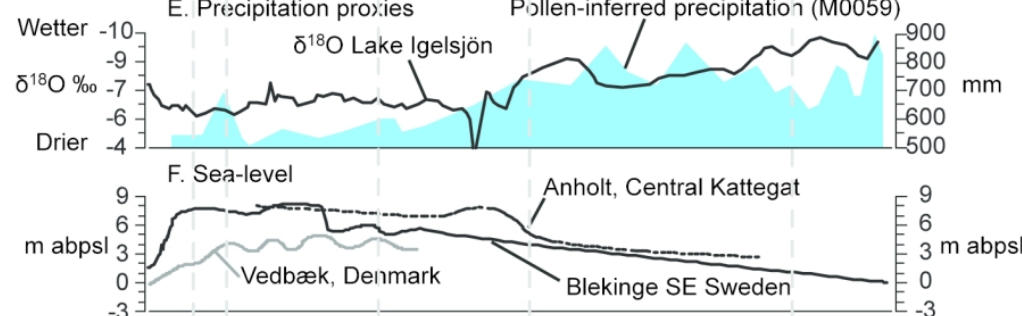

$\mathrm{g} \mathrm{L}^{-1}$ diat 20

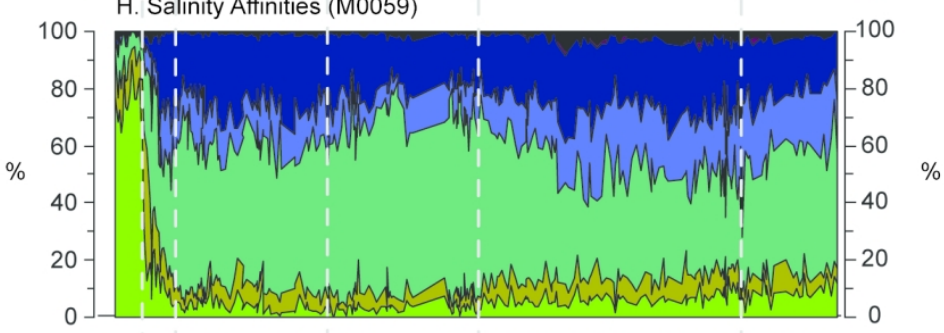

Age (BP) 


\begin{tabular}{rr|rrrrrrrr} 
Zone & \multicolumn{2}{c}{ Richness } & B:P & \multicolumn{3}{c}{ crs v/gdw ADA v/gdw \%F } & \multicolumn{2}{c}{$\%$ BF } & \multicolumn{3}{c}{$\% \mathrm{BM}$} \\
\hline & 6 & 55.97 & 0.90 & $1.08 \mathrm{E}+07$ & $3.58 \mathrm{E}+07$ & 8.7 & 5.9 & 41.9 & 20.7 \\
& 5 & 59.66 & 1.05 & $1.41 \mathrm{E}+07$ & $5.01 \mathrm{E}+07$ & 6.6 & 7.3 & 39.8 & 19.3 \\
& 4 & 46.37 & 0.54 & $7.68 \mathrm{E}+06$ & $4.16 \mathrm{E}+07$ & 3.3 & 4.9 & 61.4 & 9.8 \\
& 46.81 & 0.50 & $7.31 \mathrm{E}+06$ & $6.02 \mathrm{E}+07$ & 4.3 & 6.1 & 50.9 & 13.0 \\
& 3 & 55.13 & 1.00 & $7.20 \mathrm{E}+06$ & $2.71 \mathrm{E}+07$ & 12.8 & 14.8 & 39.1 & 12.7 \\
& 2 & 43.76 & 0.46 & $2.22 \mathrm{E}+05$ & $2.52 \mathrm{E}+07$ & 74.7 & 12.8 & 9.5 & 0.8
\end{tabular}

means 


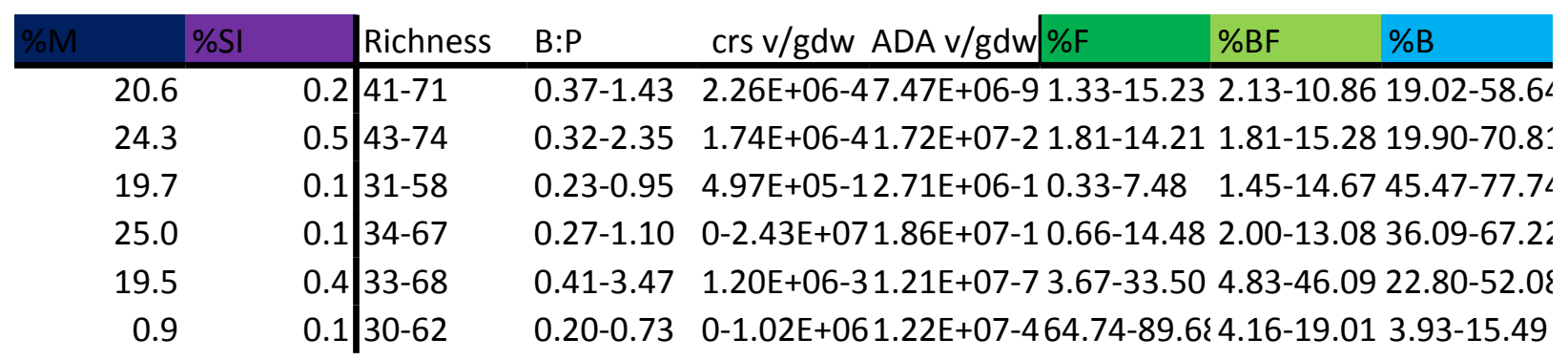

ranges 
\%BM \%M \%SI

7.72-41.53 13.27-40.6(0.00-3.31

2.48-21.96 11.00-32.9! 0.00-1.97

4.19-24.17 14.74-36.5:0.00-0.66

4.39-26.79 1.63-36.83 0.00-2.64

0.00-3.13 $\quad 0.00-3.00 \quad 0.00-1.33$ 


\begin{tabular}{c|cccccc} 
Zone & Richness & B:P & crs v/gdw & ADA v/gdw & $\% \mathrm{~F}$ & $\% \mathrm{BF}$ \\
\hline 6 & 55.97 & 0.90 & $1.08 \mathrm{E}+07$ & $3.58 \mathrm{E}+07$ & 8.7 & 5.9 \\
5 & 59.66 & 1.05 & $1.41 \mathrm{E}+07$ & $5.01 \mathrm{E}+07$ & 6.6 & 7.3 \\
4 & 46.37 & 0.54 & $7.68 \mathrm{E}+06$ & $4.16 \mathrm{E}+07$ & 3.3 & 4.9 \\
3 & 46.81 & 0.50 & $7.31 \mathrm{E}+06$ & $6.02 \mathrm{E}+07$ & 4.3 & 6.1 \\
2 & 55.13 & 1.00 & $7.20 \mathrm{E}+06$ & $2.71 \mathrm{E}+07$ & 12.8 & 14.8 \\
1 & 43.76 & 0.46 & $2.22 \mathrm{E}+05$ & $2.52 \mathrm{E}+07$ & 74.7 & 12.8 \\
\hline Zone & Richness & $\mathrm{B}: \mathrm{P}$ & crs $/ \mathrm{gdw}$ & ADA v/gdw & $\% \mathrm{~F}$ & $\% \mathrm{BF}$ \\
\hline 6 & $41-71$ & $0.37-1.43$ & $2.26 \mathrm{E}+06-4.61 \mathrm{E}+07$ & $7.47 \mathrm{E}+06-9.71 \mathrm{E}+07$ & $1.33-15.23$ & $2.13-10.86$ \\
5 & $43-74$ & $0.32-2.35$ & $1.74 \mathrm{E}+06-4.71 \mathrm{E}+07$ & $1.72 \mathrm{E}+07-2.11 \mathrm{E}+08$ & $1.81-14.21$ & $1.81-15.28$ \\
4 & $31-58$ & $0.23-0.95$ & $4.97 \mathrm{E}+05-1.97 \mathrm{E}+07$ & $2.71 \mathrm{E}+06-1.02 \mathrm{E}+08$ & $0.33-7.48$ & $1.45-14.67$ \\
3 & $34-67$ & $0.27-1.10$ & $0-2.43 \mathrm{E}+07$ & $1.86 \mathrm{E}+07-1.30 \mathrm{E}+08$ & $0.66-14.48$ & $2.00-13.08$ \\
2 & $33-68$ & $0.41-3.47$ & $1.20 \mathrm{E}+06-3.05 \mathrm{E}+07$ & $1.21 \mathrm{E}+07-7.36 \mathrm{E}+07$ & $3.67-33.50$ & $4.83-46.09$ \\
1 & $30-62$ & $0.20-0.73$ & $0-1.02 \mathrm{E}+06$ & $1.22 \mathrm{E}+07-4.49 \mathrm{E}+07$ & $64.74-89.68$ & $4.16-19.01$
\end{tabular}




\begin{tabular}{cccc} 
\%B & \%BM & $\% \mathrm{M}$ & $\% \mathrm{SI}$ \\
\hline 41.9 & 20.7 & 20.6 & 0.2 \\
39.8 & 19.3 & 24.3 & 0.5 \\
61.4 & 9.8 & 19.7 & 0.1 \\
50.9 & 13.0 & 25.0 & 0.1 \\
39.1 & 12.7 & 19.5 & 0.4 \\
9.5 & 0.8 & 0.9 & 0.1 \\
\hline$\% \mathrm{~B}$ & $\% \mathrm{BM}$ & $\% \mathrm{M}$ & $\% \mathrm{SI}$ \\
\hline $19.02-58.64$ & $10.78-47.54$ & $12.94-28.19$ & $0.00-2.65$ \\
$19.90-70.81$ & $7.72-41.53$ & $13.27-40.60$ & $0.00-3.31$ \\
$45.47-77.74$ & $2.48-21.96$ & $11.00-32.95$ & $0.00-1.97$ \\
$36.09-67.22$ & $4.19-24.17$ & $14.74-36.57$ & $0.00-0.66$ \\
$22.80-52.08$ & $4.39-26.79$ & $1.63-36.83$ & $0.00-2.64$ \\
$3.93-15.49$ & $0.00-3.13$ & $0.00-3.00$ & $0.00-1.33$
\end{tabular}




\begin{tabular}{|c|c|c|c|c|c|c|}
\hline Depth (mcd) & & & 0.02 & 0.2 & 0.4 & 0.62 \\
\hline Age (cal. a BP) & Salinity & Lifeform & -60 & -29 & 5 & 42 \\
\hline Achnanthes subatomoides & $\mathrm{F}$ & $B$ & 0.67 & 1.33 & 0.00 & 1.66 \\
\hline Cocconeis disculus & $\mathrm{F}$ & B & 2.00 & 1.49 & 0.33 & 3.15 \\
\hline Martyana martyii & $\mathrm{F}$ & B & 1.66 & 2.32 & 1.33 & 2.32 \\
\hline Staurosirella lapponica & $\mathrm{F}$ & B & 0.17 & 0.00 & 0.50 & 0.00 \\
\hline Staurosirella pinnata & $\mathrm{F}$ & B & 0.00 & 0.00 & 0.00 & 0.00 \\
\hline Tabelaria flocculosa & $\mathrm{F}$ & B & 0.00 & 0.00 & 0.00 & 0.00 \\
\hline Amphora pediculus & $\mathrm{BF}$ & B & 0.67 & 1.66 & 0.00 & 1.00 \\
\hline Cocconeis pediculus & $\mathrm{BF}$ & B & 0.00 & 0.00 & 0.00 & 0.00 \\
\hline Ctenophora pulchella & $\mathrm{BF}$ & B & 0.00 & 0.00 & 0.00 & 0.00 \\
\hline Diploneis smithii & $\mathrm{BF}$ & B & 2.00 & 1.49 & 1.67 & 0.33 \\
\hline Epithemia turgida var. westermannii & $\mathrm{BF}$ & B & 0.00 & 0.00 & 0.00 & 0.00 \\
\hline Navicula cincta & $\mathrm{BF}$ & B & 0.67 & 0.00 & 0.67 & 0.00 \\
\hline Nitzschia frustulum & $\mathrm{BF}$ & B & 0.00 & 0.00 & 0.00 & 0.00 \\
\hline Planothidium delicatum & $\mathrm{BF}$ & B & 0.00 & 0.00 & 0.00 & 0.00 \\
\hline Psuedostaurosira brevistriata & $\mathrm{BF}$ & B & 0.67 & 0.00 & 0.67 & 0.00 \\
\hline Achnanthes lemmermannii & B & B & 0.67 & 1.33 & 1.67 & 1.66 \\
\hline Cocconeis neothumensis & B & B & 0.33 & 0.00 & 0.67 & 0.00 \\
\hline Cocconeis scutellum & B & B & 1.50 & 2.82 & 6.17 & 5.64 \\
\hline Fragilaria amicorum & B & B & 2.33 & 0.00 & 2.00 & 6.30 \\
\hline Fragilaria gedanensis & B & B & 0.00 & 0.00 & 0.00 & 0.00 \\
\hline Opephora mutabilis & B & B & 1.66 & 0.00 & 0.33 & 0.33 \\
\hline Placoneis gastrum & B & B & 0.00 & 0.00 & 0.00 & 0.00 \\
\hline Psuedostaurosira perminuta & B & B & 0.67 & 0.00 & 2.33 & 0.00 \\
\hline Rhoicosphenia curvata & B & B & 0.00 & 0.00 & 2.33 & 0.00 \\
\hline Grammatophora macilenta & BM & $B$ & 1.66 & 0.83 & 0.67 & 1.99 \\
\hline Grammatophora oceanica & BM & B & 2.66 & 4.48 & 3.67 & 4.81 \\
\hline Navicula perminuta & BM & B & 0.00 & 0.00 & 0.00 & 0.00 \\
\hline Rhopalodia acuminata & BM & B & 0.17 & 0.33 & 0.67 & 1.99 \\
\hline Dimeregramma minor & $M$ & B & 1.50 & 1.00 & 1.50 & 3.32 \\
\hline Hyalodiscus scoticus & $M$ & B & 0.00 & 0.00 & 0.00 & 0.00 \\
\hline Nitzschia grossestriata & $M$ & B & 0.00 & 0.00 & 0.00 & 0.00 \\
\hline Opephora marina & $M$ & B & 0.33 & 0.00 & 0.33 & 0.66 \\
\hline Opephora minuta & $M$ & B & 1.00 & 1.00 & 0.00 & 0.66 \\
\hline Plagiogramma staurophorum & $M$ & B & 0.67 & 0.00 & 0.17 & 0.33 \\
\hline Tryblionella debilis & $M$ & B & 0.00 & 0.00 & 0.00 & 0.00 \\
\hline Aulacoseira ambigua & $\mathrm{F}$ & $P$ & 0.00 & 0.00 & 0.00 & 0.00 \\
\hline Aulacoseira granulata & $\mathrm{F}$ & $P$ & 0.33 & 0.00 & 0.00 & 0.00 \\
\hline Auloacoseira islandica & $\mathrm{F}$ & $P$ & 0.00 & 0.00 & 0.00 & 0.00 \\
\hline Cyclotella atomus & $\mathrm{F}$ & $P$ & 3.00 & 7.96 & 2.00 & 5.31 \\
\hline Cyclotella ocellata & $\mathrm{F}$ & $P$ & 0.00 & 0.00 & 0.00 & 0.00 \\
\hline Cyclotella radiosa & $\mathrm{F}$ & $P$ & 0.00 & 0.00 & 0.33 & 0.33 \\
\hline Cyclotella rossii & $\mathrm{F}$ & $P$ & 0.00 & 0.00 & 0.00 & 0.00 \\
\hline Stephanodiscus minutulus & $\mathrm{F}$ & $P$ & 0.00 & 0.00 & 0.00 & 0.00 \\
\hline Stephanodiscus neoastraea & $\mathrm{F}$ & $P$ & 0.00 & 0.00 & 0.00 & 0.00 \\
\hline Stephanodiscus parvus & $\mathrm{F}$ & $P$ & 0.00 & 0.00 & 0.00 & 0.00 \\
\hline Cyclotella menegheniana & $\mathrm{BF}$ & $P$ & 0.00 & 0.00 & 0.33 & 0.00 \\
\hline Cyclotella choctawhacheeana & B & $P$ & 4.33 & 0.66 & 3.67 & 4.64 \\
\hline Melosira moniliformis & B & $P$ & 0.33 & 0.00 & 0.00 & 0.33 \\
\hline
\end{tabular}


Paralia sulcata

Skeletonema marinoi

Thalassiosira levanderi

Thalassiosira proschkinae

Thalassionema nitzschioides

Porosira glacialis

Proboscia alata

Pseudosolenia calcar-avis

Rhizosolenia pungens

Thalassiosira cf. angulata

Thalassiosira eccentrica

Shionodiscus oestrupii

Stauroneis radissonii

Melosira varians

\begin{tabular}{ll|}
$B$ & $P$ \\
$B$ & $P$ \\
$B$ & $P$ \\
$B$ & $P$ \\
$B M$ & $P$ \\
$M$ & $P$ \\
$M$ & $P$ \\
$M$ & $P$ \\
$M$ & $P$ \\
$M$ & $P$ \\
$M$ & $P$ \\
$M$ & $P$ \\
$S I$ & $P$ \\
$S I$ & $P$
\end{tabular}

11.65

0.00

7.99

3.99

12.65

3.33

0.33

0.33

1.33

0.67

3.99

7.65

0.00

0.00

$$
5.31
$$

8.67

10.61

0.00

0.00

0.00

2.99

4.33

0.33

41.46

12.00

0.00

3.65

15.50

17.58

\subsection{6}

3.00

2.32

0.00

0.00

0.00

0.00

0.00

0.00

0.33

0.00

1.66

1.33

0.00

0.00

0.00

0.00

7.33

0.66

6.30

0.00

3.32

0.00

0.00

0.00

0.33

0.00 


\begin{tabular}{|c|c|c|c|c|c|c|c|c|}
\hline 0.82 & 1.04 & 1.78 & 1.98 & 2.1 & 2.18 & 2.38 & 2.58 & 2.78 \\
\hline 75 & 113 & 237 & 271 & 291 & 305 & 339 & 373 & 406 \\
\hline 0.65 & 1.65 & 1.33 & 1.67 & 1.66 & 1.66 & 0.00 & 1.33 & 0.33 \\
\hline 1.95 & 3.30 & 0.67 & 2.67 & 1.99 & 0.83 & 0.66 & 0.67 & 1.33 \\
\hline 0.65 & 0.99 & 1.00 & 0.33 & 1.99 & 0.00 & 1.65 & 1.33 & 2.67 \\
\hline 0.00 & 0.00 & 0.50 & 0.00 & 0.00 & 0.67 & 1.32 & 2.00 & 0.67 \\
\hline 0.00 & 0.00 & 0.33 & 0.33 & 0.00 & 0.00 & 0.00 & 0.00 & 0.00 \\
\hline 0.00 & 0.00 & 0.00 & 0.00 & 0.00 & 0.00 & 0.00 & 0.00 & 0.00 \\
\hline 0.00 & 0.66 & 1.67 & 1.00 & 0.33 & 2.33 & 0.00 & 1.33 & 0.00 \\
\hline 0.16 & 0.00 & 0.00 & 0.00 & 0.00 & 0.17 & 0.00 & 0.33 & 0.00 \\
\hline 0.00 & 0.00 & 0.00 & 0.00 & 0.00 & 0.00 & 0.00 & 0.00 & 0.00 \\
\hline 0.16 & 1.32 & 0.17 & 0.83 & 1.66 & 0.83 & 1.32 & 0.50 & 1.00 \\
\hline 0.33 & 0.00 & 0.17 & 0.17 & 0.33 & 0.33 & 0.00 & 0.00 & 0.00 \\
\hline 0.00 & 0.00 & 0.67 & 0.33 & 0.00 & 1.00 & 0.99 & 0.67 & 0.67 \\
\hline 0.00 & 0.00 & 0.00 & 0.00 & 0.00 & 0.00 & 0.00 & 0.00 & 0.00 \\
\hline 0.00 & 0.00 & 0.00 & 0.67 & 0.00 & 0.00 & 0.00 & 0.00 & 0.00 \\
\hline 0.00 & 0.33 & 0.00 & 2.00 & 0.66 & 0.67 & 0.00 & 1.67 & 1.17 \\
\hline 0.00 & 0.66 & 0.67 & 0.33 & 0.33 & 0.67 & 0.99 & 1.83 & 1.00 \\
\hline 0.33 & 0.99 & 0.33 & 0.67 & 0.66 & 0.50 & 0.00 & 0.33 & 1.00 \\
\hline 5.20 & 3.63 & 5.17 & 2.17 & 3.81 & 5.16 & 4.61 & 6.17 & 4.83 \\
\hline 2.60 & 5.28 & 4.00 & 3.00 & 1.32 & 4.66 & 6.26 & 5.00 & 5.00 \\
\hline 0.00 & 0.00 & 0.00 & 0.00 & 0.00 & 0.00 & 0.00 & 0.00 & 0.00 \\
\hline 1.30 & 0.99 & 0.33 & 0.50 & 0.00 & 2.66 & 0.00 & 0.33 & 0.67 \\
\hline 0.00 & 0.00 & 0.00 & 0.00 & 0.00 & 0.00 & 0.00 & 0.00 & 0.00 \\
\hline 1.30 & 1.65 & 2.00 & 0.67 & 0.00 & 2.33 & 1.32 & 1.67 & 0.67 \\
\hline 0.00 & 0.00 & 0.33 & 0.00 & 0.00 & 0.67 & 0.16 & 0.00 & 0.00 \\
\hline 5.69 & 0.66 & 0.00 & 0.33 & 0.00 & 0.17 & 0.00 & 2.33 & 0.67 \\
\hline 4.55 & 3.14 & 1.83 & 2.67 & 0.83 & 2.33 & 2.97 & 2.83 & 2.17 \\
\hline 0.00 & 0.00 & 0.00 & 0.00 & 0.00 & 0.00 & 0.00 & 0.00 & 0.00 \\
\hline 0.49 & 1.49 & 2.00 & 0.67 & 0.50 & 0.50 & 0.33 & 1.33 & 2.50 \\
\hline 3.90 & 2.97 & 4.83 & 1.50 & 1.99 & 6.49 & 2.64 & 6.17 & 4.67 \\
\hline 1.95 & 0.99 & 2.67 & 1.67 & 0.00 & 1.66 & 0.99 & 2.33 & 1.00 \\
\hline 0.00 & 0.00 & 0.00 & 0.00 & 0.00 & 0.00 & 0.00 & 0.33 & 0.00 \\
\hline 0.98 & 1.32 & 1.00 & 2.33 & 0.00 & 1.50 & 0.66 & 0.17 & 0.33 \\
\hline 0.33 & 0.00 & 0.33 & 1.17 & 0.66 & 0.67 & 1.65 & 0.67 & 1.00 \\
\hline 0.49 & 0.00 & 0.50 & 0.83 & 0.00 & 1.16 & 1.81 & 0.67 & 0.17 \\
\hline 0.00 & 0.00 & 0.00 & 0.00 & 0.00 & 0.00 & 0.00 & 0.00 & 0.00 \\
\hline 0.00 & 0.00 & 0.00 & 0.00 & 0.66 & 0.00 & 0.00 & 0.00 & 0.00 \\
\hline 0.00 & 0.00 & 0.00 & 0.00 & 0.00 & 0.00 & 0.00 & 0.00 & 0.00 \\
\hline 0.00 & 0.00 & 0.00 & 0.00 & 0.33 & 0.00 & 0.00 & 0.00 & 0.00 \\
\hline 2.93 & 3.63 & 1.33 & 0.67 & 4.30 & 1.33 & 0.66 & 1.00 & 0.33 \\
\hline 0.00 & 0.00 & 0.00 & 0.00 & 0.33 & 0.00 & 0.00 & 0.00 & 0.00 \\
\hline 0.00 & 0.00 & 0.00 & 0.00 & 1.66 & 0.00 & 0.00 & 0.00 & 0.00 \\
\hline 0.00 & 0.00 & 0.00 & 0.00 & 0.00 & 0.00 & 0.00 & 0.00 & 0.00 \\
\hline 0.00 & 0.00 & 0.00 & 0.00 & 0.00 & 0.00 & 0.00 & 0.00 & 0.00 \\
\hline 0.00 & 0.00 & 0.33 & 0.00 & 0.00 & 0.00 & 0.00 & 0.00 & 0.00 \\
\hline 0.00 & 0.00 & 0.00 & 0.00 & 0.00 & 0.00 & 0.00 & 0.00 & 0.00 \\
\hline 0.98 & 0.00 & 0.00 & 0.00 & 0.99 & 0.00 & 0.00 & 0.33 & 0.67 \\
\hline 18.86 & 1.98 & 1.33 & 0.33 & 3.97 & 0.67 & 0.33 & 5.67 & 1.33 \\
\hline 0.00 & 0.00 & 0.00 & 0.00 & 0.00 & 0.00 & 0.00 & 0.00 & 0.00 \\
\hline
\end{tabular}




$\begin{array}{rrrrrrrrr}17.24 & 10.23 & 31.67 & 36.33 & 21.52 & 28.29 & 33.61 & 16.00 & 30.67 \\ 0.00 & 0.00 & 0.00 & 0.33 & 0.00 & 0.00 & 0.00 & 0.00 & 0.00 \\ 0.33 & 12.21 & 0.00 & 0.33 & 0.00 & 0.00 & 0.00 & 0.00 & 0.33 \\ 0.00 & 0.99 & 0.00 & 0.00 & 0.00 & 0.00 & 0.33 & 1.00 & 0.67 \\ 6.02 & 16.83 & 13.17 & 17.33 & 19.37 & 8.82 & 8.40 & 16.50 & 9.50 \\ 0.65 & 0.66 & 0.33 & 0.00 & 8.61 & 0.33 & 0.33 & 0.00 & 0.00 \\ 0.00 & 0.00 & 0.00 & 0.00 & 0.00 & 0.00 & 0.33 & 1.33 & 0.00 \\ 0.00 & 0.00 & 0.00 & 0.00 & 0.99 & 0.00 & 0.33 & 0.00 & 0.00 \\ 0.00 & 0.00 & 0.00 & 0.00 & 0.00 & 0.00 & 0.99 & 1.33 & 0.00 \\ 0.33 & 0.00 & 4.00 & 0.67 & 0.33 & 1.33 & 2.31 & 0.33 & 4.67 \\ 0.65 & 1.32 & 0.00 & 0.00 & 0.00 & 0.00 & 0.33 & 0.00 & 0.00 \\ 2.93 & 9.90 & 3.33 & 1.00 & 2.65 & 1.33 & 1.98 & 1.00 & 3.33 \\ 0.65 & 0.00 & 0.00 & 0.00 & 0.00 & 0.00 & 0.00 & 0.00 & 0.00 \\ 0.00 & 0.00 & 0.00 & 0.00 & 0.00 & 0.00 & 0.00 & 0.00 & 0.00\end{array}$




\begin{tabular}{|c|c|c|c|c|c|c|c|c|}
\hline 3.18 & 3.75 & 3.95 & 4.11 & 4.15 & 4.26 & 4.38 & 4.81 & 4.96 \\
\hline 493 & 622 & 667 & 703 & 712 & 737 & 764 & 862 & 895 \\
\hline 0.66 & 1.65 & 0.33 & 1.97 & 0.00 & 2.00 & 0.00 & 1.00 & 1.63 \\
\hline 1.48 & 0.66 & 0.66 & 1.64 & 0.00 & 0.50 & 1.83 & 0.83 & 0.65 \\
\hline 0.66 & 1.98 & 0.00 & 4.61 & 1.61 & 0.00 & 1.00 & 0.66 & 0.33 \\
\hline 0.49 & 0.50 & 0.00 & 0.00 & 0.00 & 4.50 & 0.00 & 3.32 & 0.00 \\
\hline 0.33 & 0.00 & 0.00 & 0.00 & 0.00 & 0.00 & 0.00 & 0.00 & 0.00 \\
\hline 0.00 & 0.00 & 0.00 & 0.00 & 0.00 & 0.00 & 0.00 & 0.00 & 0.00 \\
\hline 4.93 & 1.98 & 0.00 & 0.66 & 0.32 & 0.00 & 0.67 & 0.33 & 2.29 \\
\hline 0.16 & 0.50 & 0.00 & 0.00 & 0.00 & 0.00 & 0.00 & 0.33 & 0.00 \\
\hline 0.00 & 0.00 & 0.00 & 0.00 & 0.00 & 0.00 & 0.00 & 0.00 & 0.00 \\
\hline 0.82 & 0.33 & 0.33 & 1.64 & 1.61 & 1.33 & 0.50 & 0.33 & 0.49 \\
\hline 0.16 & 0.66 & 0.00 & 0.00 & 0.00 & 0.17 & 0.17 & 0.66 & 0.00 \\
\hline 0.99 & 0.66 & 0.00 & 1.64 & 0.00 & 0.00 & 0.00 & 0.00 & 0.00 \\
\hline 0.00 & 0.00 & 0.00 & 0.00 & 0.00 & 0.00 & 0.00 & 0.00 & 0.00 \\
\hline 0.00 & 0.00 & 0.00 & 0.00 & 0.00 & 0.00 & 0.00 & 0.00 & 0.00 \\
\hline 0.99 & 1.32 & 1.99 & 0.00 & 2.42 & 1.83 & 0.33 & 2.65 & 3.92 \\
\hline 1.32 & 2.97 & 0.00 & 1.97 & 1.61 & 0.67 & 1.00 & 0.66 & 1.63 \\
\hline 0.49 & 1.65 & 0.33 & 0.00 & 0.65 & 1.00 & 0.00 & 0.00 & 0.65 \\
\hline 2.47 & 4.29 & 1.66 & 2.47 & 2.42 & 3.50 & 4.17 & 1.99 & 3.10 \\
\hline 4.61 & 5.28 & 1.99 & 1.64 & 5.48 & 4.67 & 3.67 & 0.33 & 6.21 \\
\hline 0.00 & 0.00 & 0.00 & 0.00 & 0.00 & 0.00 & 0.00 & 0.00 & 0.00 \\
\hline 1.81 & 0.33 & 0.33 & 0.00 & 1.29 & 2.00 & 0.50 & 0.66 & 4.58 \\
\hline 0.00 & 0.00 & 0.00 & 0.00 & 0.00 & 0.00 & 0.00 & 0.00 & 0.00 \\
\hline 0.99 & 1.98 & 1.00 & 0.00 & 2.58 & 5.00 & 4.33 & 2.32 & 2.29 \\
\hline 0.00 & 0.00 & 0.00 & 0.00 & 0.32 & 0.00 & 0.00 & 0.00 & 0.16 \\
\hline 0.00 & 1.65 & 0.00 & 0.00 & 1.29 & 1.00 & 0.67 & 0.50 & 0.82 \\
\hline 0.66 & 2.31 & 1.00 & 4.93 & 1.61 & 3.00 & 2.33 & 6.97 & 6.70 \\
\hline 0.00 & 0.00 & 0.00 & 0.00 & 0.00 & 0.00 & 0.00 & 0.00 & 0.00 \\
\hline 1.15 & 1.49 & 1.00 & 2.80 & 2.26 & 1.17 & 1.50 & 1.49 & 0.98 \\
\hline 3.29 & 3.14 & 7.14 & 2.96 & 3.55 & 5.00 & 3.33 & 5.80 & 3.27 \\
\hline 1.97 & 0.00 & 0.00 & 0.00 & 2.58 & 2.00 & 0.00 & 3.65 & 2.29 \\
\hline 0.33 & 0.00 & 0.00 & 0.00 & 0.00 & 0.00 & 0.00 & 0.00 & 0.00 \\
\hline 0.66 & 2.97 & 0.33 & 0.00 & 0.16 & 1.83 & 0.33 & 1.00 & 1.96 \\
\hline 0.99 & 4.13 & 1.33 & 0.99 & 0.00 & 0.67 & 0.67 & 0.66 & 2.12 \\
\hline 0.49 & 2.15 & 1.16 & 3.45 & 1.94 & 2.67 & 0.00 & 0.66 & 1.31 \\
\hline 0.00 & 0.00 & 0.00 & 0.00 & 0.00 & 0.00 & 0.00 & 0.00 & 0.00 \\
\hline 0.00 & 0.00 & 0.00 & 0.00 & 0.00 & 0.00 & 0.00 & 0.00 & 0.00 \\
\hline 0.00 & 0.00 & 0.00 & 0.00 & 0.00 & 0.00 & 0.33 & 0.33 & 0.00 \\
\hline 0.00 & 0.00 & 0.00 & 0.00 & 0.00 & 0.00 & 0.00 & 0.00 & 0.00 \\
\hline 2.63 & 1.98 & 0.66 & 0.00 & 4.84 & 4.33 & 2.67 & 0.00 & 0.98 \\
\hline 0.00 & 0.00 & 0.00 & 0.00 & 0.00 & 0.00 & 0.00 & 0.00 & 0.00 \\
\hline 0.00 & 0.00 & 0.00 & 0.66 & 0.00 & 0.00 & 0.00 & 0.00 & 0.00 \\
\hline 0.00 & 0.00 & 0.00 & 0.00 & 0.00 & 0.00 & 0.00 & 0.00 & 0.00 \\
\hline 0.00 & 0.00 & 0.00 & 0.00 & 0.00 & 0.00 & 0.00 & 0.00 & 0.00 \\
\hline 0.00 & 0.00 & 0.00 & 0.00 & 0.00 & 0.00 & 0.00 & 0.00 & 0.00 \\
\hline 0.00 & 0.00 & 0.00 & 0.00 & 0.00 & 0.00 & 0.00 & 0.00 & 0.00 \\
\hline 0.00 & 0.00 & 0.00 & 0.00 & 0.00 & 0.00 & 0.00 & 0.00 & 0.00 \\
\hline 2.96 & 0.99 & 0.00 & 0.33 & 1.61 & 1.00 & 0.33 & 2.32 & 1.31 \\
\hline 0.33 & 0.00 & 0.00 & 0.00 & 0.00 & 0.00 & 0.00 & 0.00 & 0.00 \\
\hline
\end{tabular}




$\begin{array}{rrrrrrrrr}25.00 & 19.47 & 51.50 & 14.80 & 26.13 & 13.33 & 20.00 & 21.89 & 20.26 \\ 0.00 & 0.00 & 0.00 & 0.00 & 0.00 & 0.00 & 0.00 & 0.00 & 0.00 \\ 0.66 & 0.66 & 0.00 & 0.33 & 0.00 & 0.33 & 0.67 & 0.00 & 0.33 \\ 0.33 & 0.33 & 0.00 & 1.64 & 0.00 & 0.00 & 0.33 & 0.00 & 0.65 \\ 11.18 & 9.57 & 10.47 & 18.09 & 12.10 & 9.67 & 21.33 & 8.29 & 7.35 \\ 0.00 & 3.63 & 2.99 & 2.96 & 0.65 & 1.33 & 2.67 & 0.00 & 0.00 \\ 0.00 & 0.00 & 0.00 & 0.00 & 0.97 & 0.00 & 1.00 & 0.00 & 0.98 \\ 0.99 & 0.33 & 1.33 & 0.33 & 0.97 & 2.67 & 1.67 & 1.00 & 0.98 \\ 0.33 & 0.00 & 0.00 & 0.33 & 0.32 & 0.67 & 0.33 & 3.65 & 1.63 \\ 0.33 & 2.64 & 0.00 & 0.00 & 4.84 & 0.00 & 0.00 & 0.66 & 0.00 \\ 0.00 & 0.00 & 0.33 & 0.33 & 0.32 & 0.67 & 2.00 & 1.33 & 1.63 \\ 3.62 & 0.66 & 1.33 & 5.26 & 2.26 & 1.33 & 4.67 & 3.32 & 3.92 \\ 0.00 & 0.00 & 0.33 & 0.66 & 0.00 & 0.00 & 0.00 & 0.00 & 0.00 \\ 0.99 & 0.00 & 0.00 & 0.00 & 0.00 & 1.00 & 0.00 & 0.00 & 0.00\end{array}$




\begin{tabular}{|c|c|c|c|c|c|c|c|c|}
\hline 5.16 & 5.38 & 5.61 & 5.77 & 5.78 & 5.96 & 5.97 & 5.98 & 6.17 \\
\hline 914 & 933 & 953 & 966 & 967 & 983 & 983 & 984 & 1000 \\
\hline 0.99 & 0.00 & 1.98 & 0.33 & 0.00 & 3.00 & 0.00 & 1.00 & 1.32 \\
\hline 0.99 & 0.00 & 0.33 & 0.66 & 0.33 & 1.00 & 0.50 & 0.00 & 0.99 \\
\hline 0.66 & 0.00 & 0.99 & 1.97 & 0.00 & 0.67 & 0.00 & 0.33 & 1.32 \\
\hline 2.98 & 0.00 & 0.17 & 0.49 & 0.65 & 2.00 & 0.33 & 0.00 & 0.00 \\
\hline 0.00 & 0.00 & 0.00 & 1.31 & 1.30 & 0.00 & 0.33 & 0.33 & 0.00 \\
\hline 0.00 & 0.00 & 0.00 & 0.00 & 0.00 & 0.00 & 0.00 & 0.00 & 0.00 \\
\hline 0.00 & 1.00 & 0.00 & 0.00 & 0.65 & 2.00 & 1.66 & 0.33 & 0.66 \\
\hline 0.00 & 0.00 & 0.66 & 0.00 & 0.00 & 0.00 & 0.00 & 0.00 & 0.33 \\
\hline 0.00 & 0.00 & 0.00 & 0.00 & 0.00 & 0.00 & 0.00 & 0.00 & 0.00 \\
\hline 1.16 & 1.16 & 0.17 & 1.15 & 1.95 & 1.33 & 1.33 & 0.83 & 0.99 \\
\hline 0.00 & 0.33 & 0.17 & 0.00 & 0.00 & 0.17 & 0.00 & 0.17 & 0.00 \\
\hline 0.00 & 1.33 & 0.66 & 0.00 & 0.00 & 0.00 & 0.00 & 0.00 & 0.00 \\
\hline 0.00 & 0.00 & 0.00 & 0.00 & 0.00 & 0.00 & 0.00 & 0.00 & 0.00 \\
\hline 0.00 & 0.00 & 0.00 & 0.00 & 0.65 & 0.00 & 0.00 & 0.33 & 0.00 \\
\hline 1.99 & 0.17 & 3.31 & 0.98 & 2.28 & 0.00 & 0.50 & 1.67 & 2.31 \\
\hline 1.99 & 3.32 & 0.66 & 1.31 & 0.00 & 1.00 & 0.00 & 0.33 & 0.99 \\
\hline 0.33 & 1.16 & 0.33 & 0.00 & 0.33 & 0.67 & 0.00 & 0.67 & 0.33 \\
\hline 4.14 & 4.48 & 1.16 & 0.66 & 4.23 & 5.67 & 1.83 & 2.17 & 2.48 \\
\hline 2.65 & 10.28 & 9.59 & 0.98 & 4.89 & 7.00 & 5.66 & 6.33 & 4.63 \\
\hline 0.00 & 0.00 & 0.00 & 0.00 & 0.00 & 0.00 & 0.00 & 0.00 & 0.00 \\
\hline 0.66 & 1.00 & 1.49 & 0.33 & 2.28 & 0.00 & 0.33 & 0.67 & 3.14 \\
\hline 0.00 & 0.00 & 0.00 & 0.00 & 0.00 & 0.00 & 0.00 & 0.00 & 0.00 \\
\hline 7.95 & 0.33 & 7.27 & 0.00 & 2.61 & 0.00 & 2.66 & 4.67 & 6.28 \\
\hline 0.00 & 0.66 & 0.33 & 0.66 & 0.16 & 0.00 & 0.83 & 0.00 & 0.00 \\
\hline 0.66 & 1.00 & 1.49 & 0.33 & 0.00 & 0.00 & 0.00 & 0.00 & 0.00 \\
\hline 5.30 & 2.32 & 0.83 & 1.97 & 2.12 & 1.00 & 2.83 & 1.17 & 3.97 \\
\hline 0.00 & 0.00 & 0.00 & 0.00 & 0.00 & 0.00 & 0.00 & 0.00 & 0.00 \\
\hline 3.81 & 1.66 & 2.31 & 2.13 & 1.79 & 0.00 & 1.00 & 1.67 & 0.99 \\
\hline 2.98 & 6.63 & 6.78 & 3.61 & 6.19 & 3.17 & 4.49 & 5.33 & 5.95 \\
\hline 1.66 & 2.65 & 0.66 & 2.30 & 3.26 & 0.00 & 2.00 & 2.33 & 3.97 \\
\hline 0.33 & 0.00 & 0.00 & 0.00 & 0.00 & 0.00 & 0.67 & 0.00 & 0.00 \\
\hline 0.33 & 0.83 & 2.81 & 0.00 & 0.65 & 1.67 & 0.67 & 1.00 & 2.15 \\
\hline 0.66 & 0.00 & 0.66 & 0.66 & 0.98 & 3.00 & 3.16 & 1.67 & 1.16 \\
\hline 1.16 & 0.50 & 0.33 & 0.33 & 0.33 & 0.33 & 0.17 & 1.67 & 1.65 \\
\hline 0.00 & 0.00 & 0.00 & 0.00 & 0.00 & 0.00 & 0.00 & 0.00 & 0.00 \\
\hline 0.00 & 0.00 & 0.33 & 0.00 & 0.00 & 0.00 & 0.00 & 0.00 & 0.00 \\
\hline 0.00 & 0.00 & 0.00 & 0.00 & 0.00 & 0.00 & 0.00 & 0.00 & 0.00 \\
\hline 0.00 & 0.00 & 0.00 & 0.00 & 0.00 & 0.00 & 0.00 & 0.00 & 0.00 \\
\hline 1.99 & 0.00 & 0.33 & 0.33 & 0.65 & 0.00 & 0.33 & 1.67 & 0.66 \\
\hline 0.00 & 0.00 & 0.00 & 0.00 & 0.00 & 0.00 & 0.00 & 0.00 & 0.00 \\
\hline 0.00 & 0.00 & 0.00 & 0.00 & 0.00 & 0.00 & 0.33 & 0.00 & 0.00 \\
\hline 0.00 & 0.00 & 0.00 & 0.00 & 0.00 & 0.00 & 0.00 & 0.00 & 0.00 \\
\hline 0.00 & 0.00 & 0.00 & 0.00 & 0.00 & 0.00 & 0.00 & 0.00 & 0.00 \\
\hline 0.00 & 0.00 & 0.00 & 0.00 & 0.00 & 0.00 & 0.00 & 0.00 & 0.00 \\
\hline 0.00 & 0.00 & 0.00 & 0.00 & 0.00 & 0.00 & 0.00 & 0.00 & 0.00 \\
\hline 0.00 & 0.00 & 0.00 & 0.00 & 0.00 & 0.00 & 0.00 & 0.00 & 0.00 \\
\hline 1.66 & 1.00 & 1.32 & 0.00 & 0.65 & 5.00 & 0.67 & 1.67 & 4.30 \\
\hline 0.00 & 0.00 & 0.00 & 0.00 & 0.00 & 0.00 & 0.00 & 0.00 & 0.00 \\
\hline
\end{tabular}




$\begin{array}{rrrrrrrrr}15.89 & 27.53 & 7.60 & 12.79 & 21.82 & 14.67 & 32.95 & 9.00 & 12.56 \\ 0.00 & 0.00 & 0.00 & 0.00 & 2.28 & 0.00 & 0.00 & 0.33 & 0.00 \\ 0.99 & 0.00 & 0.00 & 0.00 & 0.33 & 0.00 & 0.67 & 0.67 & 0.00 \\ 0.00 & 0.33 & 0.00 & 0.00 & 0.00 & 0.00 & 0.00 & 0.00 & 0.00 \\ 14.07 & 9.78 & 22.98 & 41.48 & 8.63 & 12.33 & 5.82 & 36.00 & 10.08 \\ 0.00 & 0.00 & 0.00 & 0.66 & 1.95 & 2.67 & 0.67 & 0.00 & 4.63 \\ 0.00 & 0.00 & 0.66 & 0.66 & 0.00 & 0.00 & 0.00 & 0.00 & 0.66 \\ 0.33 & 0.33 & 1.98 & 1.64 & 0.98 & 1.33 & 2.00 & 0.33 & 1.65 \\ 0.00 & 0.66 & 1.32 & 0.33 & 0.65 & 1.00 & 0.33 & 1.00 & 1.98 \\ 0.33 & 0.00 & 0.33 & 0.98 & 1.30 & 0.00 & 1.66 & 0.00 & 0.33 \\ 1.32 & 0.66 & 0.00 & 0.33 & 0.33 & 4.00 & 0.67 & 0.33 & 0.66 \\ 4.64 & 6.30 & 1.98 & 6.56 & 1.95 & 6.33 & 2.33 & 1.33 & 1.65 \\ 0.00 & 0.00 & 0.00 & 0.00 & 0.00 & 0.00 & 0.00 & 0.00 & 0.00 \\ 0.00 & 0.00 & 0.00 & 0.00 & 0.00 & 0.00 & 0.00 & 0.33 & 0.00\end{array}$




\begin{tabular}{|c|c|c|c|c|c|c|c|c|}
\hline 6.19 & 6.39 & 6.59 & 6.79 & 6.99 & 7.19 & 7.21 & 7.39 & 7.59 \\
\hline 1002 & 1019 & 1036 & 1054 & 1071 & 1088 & 1090 & 1105 & 1122 \\
\hline 1.33 & 2.66 & 0.65 & 1.99 & 1.66 & 1.33 & 2.31 & 0.33 & 0.33 \\
\hline 1.00 & 0.66 & 0.00 & 0.17 & 1.33 & 0.33 & 0.99 & 0.33 & 1.00 \\
\hline 0.00 & 0.33 & 0.65 & 0.00 & 0.33 & 0.00 & 0.00 & 0.33 & 0.00 \\
\hline 0.00 & 1.33 & 1.14 & 0.66 & 0.33 & 0.67 & 0.99 & 0.83 & 2.51 \\
\hline 1.67 & 4.32 & 2.28 & 0.00 & 5.66 & 2.00 & 0.00 & 3.33 & 5.35 \\
\hline 0.00 & 0.00 & 0.00 & 0.00 & 0.00 & 0.00 & 0.00 & 0.00 & 0.00 \\
\hline 1.67 & 1.33 & 2.28 & 1.66 & 1.00 & 0.00 & 1.32 & 0.33 & 0.00 \\
\hline 0.00 & 0.33 & 0.00 & 0.33 & 0.00 & 0.00 & 0.00 & 0.33 & 0.33 \\
\hline 0.00 & 0.00 & 0.00 & 0.00 & 0.00 & 0.00 & 0.00 & 0.00 & 0.00 \\
\hline 1.00 & 0.50 & 1.14 & 1.00 & 0.50 & 1.17 & 0.50 & 0.83 & 0.00 \\
\hline 0.00 & 0.17 & 0.16 & 0.00 & 0.17 & 0.33 & 0.99 & 0.33 & 0.33 \\
\hline 0.00 & 1.00 & 3.92 & 0.66 & 0.33 & 0.00 & 0.00 & 0.00 & 0.00 \\
\hline 0.33 & 0.00 & 0.00 & 0.00 & 0.00 & 0.00 & 0.00 & 0.00 & 0.00 \\
\hline 1.50 & 0.66 & 0.00 & 0.00 & 0.33 & 1.33 & 1.65 & 0.67 & 0.33 \\
\hline 2.00 & 1.83 & 1.31 & 0.66 & 1.83 & 2.33 & 2.31 & 2.33 & 1.00 \\
\hline 0.00 & 0.00 & 0.65 & 0.33 & 0.33 & 0.00 & 0.00 & 0.00 & 0.33 \\
\hline 0.33 & 0.00 & 0.98 & 0.33 & 0.00 & 0.00 & 0.33 & 0.17 & 0.00 \\
\hline 4.50 & 3.49 & 3.26 & 3.82 & 1.66 & 2.33 & 3.80 & 5.83 & 3.34 \\
\hline 6.67 & 1.00 & 8.81 & 9.30 & 5.99 & 4.00 & 3.31 & 0.33 & 4.35 \\
\hline 0.00 & 0.00 & 0.00 & 0.00 & 0.00 & 0.00 & 0.66 & 0.00 & 0.00 \\
\hline 4.33 & 0.66 & 3.43 & 0.00 & 1.00 & 1.00 & 0.66 & 3.00 & 1.34 \\
\hline 0.00 & 0.00 & 0.00 & 0.33 & 0.00 & 0.33 & 0.33 & 0.00 & 0.00 \\
\hline 3.67 & 2.99 & 2.28 & 4.32 & 2.33 & 2.00 & 1.98 & 1.33 & 2.68 \\
\hline 0.00 & 0.83 & 0.00 & 0.00 & 0.00 & 0.00 & 0.00 & 0.83 & 0.67 \\
\hline 0.17 & 0.00 & 0.16 & 0.17 & 1.16 & 0.17 & 0.83 & 0.00 & 0.00 \\
\hline 0.00 & 1.00 & 2.61 & 2.49 & 1.50 & 2.50 & 2.31 & 0.50 & 0.84 \\
\hline 0.00 & 0.00 & 0.00 & 0.00 & 0.00 & 0.00 & 0.00 & 0.00 & 0.00 \\
\hline 2.83 & 1.33 & 0.98 & 0.50 & 1.33 & 1.00 & 1.65 & 1.17 & 1.51 \\
\hline 4.83 & 1.66 & 4.73 & 2.99 & 4.33 & 5.33 & 5.29 & 2.00 & 9.03 \\
\hline 4.67 & 1.99 & 4.24 & 2.33 & 2.00 & 3.67 & 2.64 & 2.67 & 2.01 \\
\hline 0.00 & 0.00 & 0.16 & 0.00 & 0.50 & 0.00 & 0.33 & 0.00 & 0.17 \\
\hline 1.17 & 1.00 & 2.28 & 0.66 & 0.33 & 0.00 & 0.50 & 1.83 & 1.67 \\
\hline 3.67 & 0.66 & 0.98 & 0.00 & 2.66 & 1.33 & 4.63 & 0.67 & 1.51 \\
\hline 1.83 & 0.00 & 2.28 & 2.66 & 0.67 & 1.50 & 0.50 & 0.67 & 2.68 \\
\hline 0.00 & 0.00 & 0.00 & 0.00 & 0.00 & 0.00 & 0.00 & 0.00 & 0.00 \\
\hline 0.00 & 0.00 & 0.00 & 0.00 & 0.00 & 0.00 & 0.00 & 0.00 & 0.33 \\
\hline 0.00 & 0.00 & 0.00 & 0.00 & 0.00 & 0.00 & 0.00 & 0.00 & 0.00 \\
\hline 0.00 & 0.00 & 0.00 & 0.00 & 0.00 & 0.00 & 0.00 & 0.00 & 0.00 \\
\hline 0.33 & 0.66 & 0.98 & 3.32 & 0.33 & 1.00 & 0.99 & 2.00 & 0.00 \\
\hline 0.00 & 0.00 & 0.00 & 0.00 & 0.00 & 0.00 & 0.00 & 0.00 & 0.00 \\
\hline 0.00 & 0.00 & 0.00 & 0.00 & 0.00 & 0.00 & 0.00 & 0.00 & 0.00 \\
\hline 0.00 & 0.00 & 0.00 & 0.00 & 0.00 & 0.00 & 0.00 & 0.67 & 0.00 \\
\hline 0.00 & 0.00 & 0.00 & 0.00 & 0.00 & 0.00 & 0.00 & 0.00 & 0.00 \\
\hline 0.00 & 0.00 & 0.00 & 0.00 & 0.00 & 0.00 & 0.00 & 0.00 & 0.00 \\
\hline 0.00 & 0.00 & 0.00 & 0.00 & 0.00 & 0.00 & 0.00 & 0.00 & 0.00 \\
\hline 0.33 & 0.33 & 0.00 & 0.00 & 0.00 & 0.67 & 0.00 & 1.00 & 0.00 \\
\hline 0.67 & 1.99 & 0.33 & 1.33 & 0.67 & 2.00 & 1.65 & 2.67 & 1.67 \\
\hline 0.00 & 0.00 & 0.00 & 1.00 & 0.33 & 0.00 & 0.00 & 0.00 & 0.00 \\
\hline
\end{tabular}




$\begin{array}{rrrrrrrrr}10.33 & 6.64 & 4.89 & 20.27 & 13.64 & 12.67 & 11.57 & 14.67 & 13.38 \\ 0.33 & 0.33 & 0.00 & 0.33 & 1.33 & 0.00 & 1.98 & 0.00 & 1.00 \\ 0.33 & 0.00 & 0.00 & 0.33 & 2.00 & 0.00 & 0.00 & 0.00 & 0.33 \\ 0.00 & 0.00 & 0.00 & 0.00 & 0.33 & 0.00 & 0.00 & 0.00 & 0.33 \\ 16.50 & 37.38 & 12.40 & 10.47 & 16.31 & 15.33 & 16.53 & 18.00 & 10.70 \\ 0.00 & 0.33 & 0.33 & 0.00 & 0.00 & 1.33 & 0.00 & 0.67 & 1.67 \\ 0.00 & 0.33 & 0.33 & 0.00 & 0.67 & 0.00 & 0.00 & 0.33 & 0.00 \\ 1.33 & 1.99 & 3.59 & 1.33 & 0.67 & 2.00 & 0.33 & 3.00 & 2.68 \\ 0.67 & 0.00 & 2.28 & 0.66 & 1.33 & 0.67 & 0.00 & 3.00 & 0.67 \\ 0.33 & 0.33 & 0.33 & 2.33 & 0.67 & 1.00 & 0.00 & 0.00 & 0.00 \\ 0.00 & 0.33 & 0.00 & 1.66 & 0.33 & 2.00 & 0.00 & 0.33 & 1.67 \\ 2.00 & 1.99 & 2.28 & 2.66 & 6.66 & 1.67 & 5.29 & 9.00 & 2.68 \\ 1.00 & 0.66 & 0.00 & 0.00 & 0.00 & 0.33 & 2.98 & 0.67 & 0.00 \\ 1.33 & 0.66 & 0.00 & 0.00 & 0.67 & 1.00 & 2.31 & 0.00 & 0.33\end{array}$




\begin{tabular}{|c|c|c|c|c|c|c|c|c|}
\hline 7.79 & 7.81 & 7.94 & 7.98 & 8.12 & 8.19 & 8.33 & 8.52 & 8.71 \\
\hline 1139 & 1141 & 1152 & 1156 & 1168 & 1174 & 1186 & 1203 & 1218 \\
\hline 1.00 & 0.33 & 0.33 & 2.29 & 1.00 & 2.30 & 1.00 & 0.67 & 1.98 \\
\hline 1.16 & 0.00 & 1.83 & 1.15 & 0.67 & 0.00 & 1.17 & 0.33 & 1.16 \\
\hline 0.00 & 0.00 & 0.00 & 0.33 & 0.00 & 0.33 & 0.67 & 0.00 & 0.00 \\
\hline 0.00 & 0.00 & 0.00 & 1.31 & 1.00 & 0.33 & 0.00 & 2.83 & 0.00 \\
\hline 1.00 & 0.66 & 1.00 & 4.26 & 1.00 & 2.96 & 1.33 & 0.67 & 1.98 \\
\hline 0.00 & 0.00 & 0.00 & 0.00 & 0.00 & 0.00 & 0.00 & 0.00 & 0.00 \\
\hline 1.00 & 1.31 & 0.67 & 1.64 & 2.00 & 0.00 & 1.33 & 1.33 & 1.32 \\
\hline 0.66 & 0.66 & 0.00 & 0.33 & 0.00 & 0.66 & 0.17 & 0.00 & 0.00 \\
\hline 0.00 & 0.00 & 0.00 & 0.00 & 0.00 & 0.00 & 0.00 & 0.00 & 0.00 \\
\hline 0.66 & 0.49 & 0.50 & 1.47 & 0.50 & 0.82 & 1.50 & 2.17 & 0.33 \\
\hline 0.33 & 0.00 & 0.17 & 0.00 & 0.00 & 0.00 & 0.00 & 0.17 & 0.00 \\
\hline 0.00 & 0.00 & 0.67 & 0.00 & 0.00 & 0.00 & 2.50 & 0.00 & 0.00 \\
\hline 0.00 & 0.00 & 0.00 & 0.00 & 0.00 & 0.00 & 0.00 & 0.00 & 0.00 \\
\hline 0.66 & 1.31 & 0.33 & 1.96 & 0.50 & 0.49 & 0.00 & 0.00 & 0.99 \\
\hline 3.99 & 1.64 & 0.00 & 1.31 & 2.67 & 0.00 & 2.67 & 1.17 & 3.47 \\
\hline 0.66 & 0.00 & 0.00 & 0.00 & 0.00 & 0.66 & 0.83 & 0.00 & 0.33 \\
\hline 0.33 & 0.00 & 0.33 & 0.65 & 0.00 & 0.33 & 0.00 & 0.33 & 0.66 \\
\hline 3.32 & 2.13 & 4.33 & 2.78 & 4.33 & 4.43 & 1.33 & 3.83 & 3.47 \\
\hline 5.98 & 1.97 & 2.33 & 3.93 & 2.33 & 2.96 & 9.00 & 0.67 & 3.97 \\
\hline 0.00 & 0.00 & 0.00 & 0.00 & 0.00 & 0.00 & 0.00 & 0.00 & 0.00 \\
\hline 1.99 & 0.66 & 1.00 & 3.11 & 4.33 & 1.48 & 2.83 & 1.00 & 2.15 \\
\hline 0.33 & 0.99 & 0.00 & 0.00 & 0.00 & 0.00 & 0.00 & 0.00 & 0.00 \\
\hline 4.65 & 1.64 & 1.00 & 5.07 & 9.67 & 1.31 & 2.67 & 3.83 & 3.14 \\
\hline 0.17 & 0.33 & 0.00 & 0.00 & 1.00 & 0.00 & 1.33 & 0.00 & 0.66 \\
\hline 1.66 & 0.66 & 0.00 & 0.00 & 0.67 & 0.00 & 0.33 & 0.00 & 0.00 \\
\hline 2.33 & 1.15 & 3.00 & 1.15 & 0.33 & 1.15 & 0.33 & 3.00 & 0.99 \\
\hline 0.00 & 0.00 & 0.00 & 0.00 & 0.00 & 0.00 & 0.00 & 0.00 & 0.00 \\
\hline 0.83 & 0.66 & 0.50 & 1.15 & 3.00 & 0.00 & 1.50 & 2.00 & 2.48 \\
\hline 4.82 & 1.97 & 9.32 & 4.91 & 8.50 & 1.97 & 7.00 & 6.33 & 3.80 \\
\hline 3.32 & 2.30 & 4.66 & 1.96 & 3.00 & 1.97 & 2.67 & 4.00 & 3.64 \\
\hline 0.00 & 0.66 & 0.17 & 0.00 & 0.00 & 0.00 & 0.00 & 0.00 & 0.00 \\
\hline 0.33 & 0.00 & 0.00 & 1.31 & 2.17 & 0.00 & 0.50 & 1.67 & 0.66 \\
\hline 1.66 & 2.63 & 3.00 & 4.91 & 4.00 & 1.31 & 2.83 & 1.67 & 2.64 \\
\hline 1.83 & 0.00 & 2.00 & 0.65 & 1.17 & 0.00 & 1.83 & 1.00 & 0.83 \\
\hline 0.00 & 0.00 & 0.00 & 0.00 & 0.00 & 0.00 & 0.00 & 0.00 & 0.00 \\
\hline 0.00 & 0.00 & 0.00 & 0.00 & 0.00 & 0.00 & 0.00 & 0.00 & 0.00 \\
\hline 0.00 & 0.00 & 0.00 & 0.00 & 0.00 & 0.00 & 0.00 & 0.00 & 0.00 \\
\hline 0.00 & 0.00 & 0.00 & 0.00 & 0.00 & 0.00 & 0.00 & 0.00 & 0.00 \\
\hline 1.00 & 2.63 & 0.67 & 0.33 & 0.00 & 1.31 & 0.00 & 1.33 & 1.65 \\
\hline 0.00 & 0.00 & 0.00 & 0.00 & 0.00 & 0.00 & 0.00 & 0.00 & 0.00 \\
\hline 0.00 & 0.00 & 0.00 & 0.00 & 0.00 & 0.00 & 0.00 & 0.00 & 0.00 \\
\hline 0.00 & 0.00 & 0.00 & 0.00 & 0.00 & 0.00 & 0.00 & 0.33 & 0.00 \\
\hline 0.00 & 0.00 & 0.00 & 0.00 & 0.00 & 0.00 & 0.00 & 0.00 & 0.00 \\
\hline 0.00 & 0.00 & 0.00 & 0.00 & 0.00 & 0.00 & 0.00 & 0.00 & 0.00 \\
\hline 0.00 & 0.00 & 0.00 & 0.00 & 0.00 & 0.00 & 0.00 & 0.00 & 0.00 \\
\hline 0.00 & 0.00 & 0.00 & 0.00 & 0.00 & 0.00 & 0.00 & 0.00 & 0.00 \\
\hline 2.33 & 0.99 & 0.00 & 0.98 & 0.33 & 7.88 & 2.00 & 0.00 & 2.98 \\
\hline 0.00 & 0.00 & 0 & 0.00 & 0.33 & 0.00 & 0.00 & 0.00 & 0.00 \\
\hline
\end{tabular}




$\begin{array}{rrrrrrrrr}16.61 & 7.22 & 12.65 & 15.06 & 9.33 & 3.61 & 11.33 & 14.00 & 18.51 \\ 2.99 & 35.47 & 0.33 & 0.65 & 1.33 & 3.94 & 2.33 & 1.00 & 1.32 \\ 0.33 & 0.00 & 0.33 & 0.00 & 0.00 & 0.00 & 0.00 & 0.00 & 0.00 \\ 0.33 & 0.33 & 0.00 & 0.33 & 0.00 & 0.00 & 0.00 & 0.00 & 0.00 \\ 13.62 & 9.03 & 16.47 & 8.84 & 9.67 & 37.93 & 14.33 & 21.00 & 10.08 \\ 1.00 & 0.00 & 0.67 & 1.64 & 0.00 & 0.33 & 0.33 & 0.67 & 1.32 \\ 0.00 & 0.00 & 0.00 & 0.00 & 0.00 & 0.00 & 0.00 & 0.00 & 0.00 \\ 2.66 & 2.30 & 3.33 & 0.33 & 2.00 & 1.97 & 2.00 & 0.67 & 0.99 \\ 1.00 & 0.66 & 1.00 & 0.65 & 0.00 & 0.66 & 0.33 & 0.33 & 0.33 \\ 0.33 & 0.33 & 0.00 & 1.96 & 0.67 & 0.00 & 0.00 & 0.33 & 0.00 \\ 0.33 & 0.00 & 0.00 & 0.98 & 0.67 & 0.00 & 0.33 & 0.67 & 0.66 \\ 1.33 & 2.30 & 4.66 & 8.18 & 5.00 & 4.93 & 3.33 & 4.00 & 3.31 \\ 0.00 & 0.16 & 1.00 & 0.33 & 0.33 & 0.00 & 0.00 & 0.00 & 0.00 \\ 1.00 & 0.33 & 0.33 & 0.33 & 0.33 & 0.66 & 0.33 & 1.67 & 0.33\end{array}$




\begin{tabular}{|c|c|c|c|c|c|c|c|c|}
\hline 8.91 & 9.06 & 9.11 & 9.25 & 9.31 & 9.44 & 9.51 & 9.65 & 9.81 \\
\hline 1254 & 1291 & 1304 & 1338 & 1353 & 1385 & 1402 & 1437 & 1476 \\
\hline 2.32 & 0.32 & 0.66 & 0.33 & 0.67 & 1.33 & 1.31 & 1.32 & 0.00 \\
\hline 0.66 & 0.64 & 0.33 & 0.00 & 0.33 & 0.33 & 0.33 & 0.33 & 0.33 \\
\hline 0.00 & 0.00 & 0.00 & 0.00 & 1.33 & 0.00 & 0.00 & 0.33 & 0.00 \\
\hline 0.66 & 0.00 & 0.00 & 0.33 & 0.33 & 0.00 & 0.00 & 0.00 & 0.00 \\
\hline 0.66 & 1.28 & 0.66 & 0.00 & 0.33 & 1.99 & 0.33 & 2.32 & 3.33 \\
\hline 0.00 & 0.00 & 0.00 & 0.00 & 0.00 & 0.00 & 0.00 & 0.00 & 0.00 \\
\hline 3.31 & 0.96 & 1.66 & 0.67 & 3.00 & 1.00 & 1.64 & 0.33 & 2.00 \\
\hline 0.17 & 0.00 & 0.00 & 0.00 & 0.00 & 0.50 & 0.00 & 0.00 & 0.50 \\
\hline 0.00 & 0.00 & 0.00 & 0.00 & 0.00 & 0.00 & 0.00 & 0.00 & 0.00 \\
\hline 1.16 & 1.12 & 1.33 & 1.16 & 0.17 & 0.50 & 0.49 & 1.49 & 1.67 \\
\hline 0.33 & 0.32 & 0.33 & 0.17 & 0.17 & 0.00 & 0.00 & 0.00 & 0.17 \\
\hline 0.00 & 0.00 & 0.00 & 0.00 & 1.33 & 0.00 & 0.00 & 0.00 & 0.00 \\
\hline 0.00 & 0.00 & 0.66 & 0.67 & 0.00 & 0.00 & 0.00 & 0.00 & 0.00 \\
\hline 1.16 & 1.28 & 3.99 & 0.67 & 0.00 & 2.32 & 1.47 & 0.33 & 1.67 \\
\hline 1.99 & 1.93 & 0.83 & 1.00 & 1.50 & 1.99 & 2.62 & 1.49 & 1.50 \\
\hline 0.00 & 0.00 & 0.00 & 0.00 & 1.33 & 0.00 & 0.00 & 0.00 & 0.00 \\
\hline 0.33 & 0.00 & 0.00 & 1.33 & 0.17 & 0.33 & 0.00 & 0.66 & 0.00 \\
\hline 1.66 & 3.69 & 4.15 & 2.50 & 5.17 & 3.98 & 2.95 & 3.97 & 3.33 \\
\hline 4.30 & 3.21 & 2.99 & 4.33 & 11.33 & 5.31 & 2.62 & 1.66 & 4.00 \\
\hline 0.00 & 0.00 & 0.00 & 0.00 & 0.00 & 0.33 & 0.00 & 0.00 & 0.00 \\
\hline 2.32 & 0.64 & 1.00 & 2.66 & 2.00 & 3.65 & 1.64 & 0.50 & 0.67 \\
\hline 0.00 & 0.00 & 0.66 & 0.00 & 0.00 & 0.33 & 0.33 & 0.33 & 0.00 \\
\hline 4.64 & 1.93 & 3.65 & 4.33 & 0.33 & 5.97 & 7.20 & 3.64 & 2.33 \\
\hline 0.00 & 0.64 & 0.00 & 0.00 & 0.17 & 0.50 & 0.00 & 0.00 & 0.67 \\
\hline 0.00 & 0.00 & 1.00 & 0.00 & 0.17 & 0.00 & 0.00 & 0.00 & 0.00 \\
\hline 2.48 & 4.17 & 2.16 & 1.50 & 1.67 & 0.66 & 1.15 & 0.00 & 2.83 \\
\hline 0.00 & 0.00 & 0.00 & 0.00 & 0.00 & 0.00 & 0.00 & 0.00 & 0.00 \\
\hline 1.99 & 1.93 & 1.16 & 0.83 & 1.50 & 1.66 & 4.58 & 2.98 & 2.50 \\
\hline 5.96 & 2.89 & 4.82 & 8.65 & 7.00 & 2.99 & 10.80 & 7.78 & 7.50 \\
\hline 5.96 & 2.25 & 5.65 & 4.33 & 4.33 & 4.31 & 1.64 & 2.98 & 2.33 \\
\hline 0.00 & 0.32 & 0.00 & 0.00 & 0.00 & 0.17 & 0.00 & 0.00 & 0.00 \\
\hline 0.99 & 0.96 & 2.49 & 0.50 & 1.33 & 0.66 & 0.33 & 0.83 & 1.33 \\
\hline 1.99 & 1.93 & 0.17 & 3.00 & 0.67 & 1.16 & 1.64 & 2.32 & 3.67 \\
\hline 0.33 & 1.12 & 0.00 & 1.33 & 0.83 & 2.32 & 1.64 & 0.66 & 1.50 \\
\hline 0.00 & 0.00 & 0.00 & 0.00 & 0.00 & 0.00 & 0.00 & 0.00 & 0.00 \\
\hline 0.00 & 0.00 & 0.00 & 0.00 & 0.00 & 0.00 & 0.00 & 0.00 & 0.00 \\
\hline 0.33 & 0.00 & 0.00 & 0.00 & 0.00 & 0.00 & 0.00 & 0.00 & 0.00 \\
\hline 0.00 & 0.00 & 0.00 & 0.00 & 0.00 & 0.00 & 0.00 & 0.00 & 0.00 \\
\hline 2.32 & 2.57 & 1.66 & 2.00 & 0.67 & 1.66 & 0.65 & 3.64 & 0.33 \\
\hline 0.00 & 0.00 & 0.00 & 0.00 & 0.00 & 0.00 & 0.00 & 0.00 & 0.00 \\
\hline 0.00 & 0.00 & 0.00 & 0.00 & 0.00 & 0.00 & 0.00 & 0.00 & 0.00 \\
\hline 0.00 & 0.00 & 0.00 & 0.00 & 0.00 & 0.00 & 0.00 & 0.33 & 0.00 \\
\hline 0.00 & 0.00 & 0.00 & 0.00 & 0.00 & 0.00 & 0.00 & 0.00 & 0.00 \\
\hline 0.00 & 0.00 & 0.00 & 0.00 & 0.00 & 0.00 & 0.00 & 0.00 & 0.00 \\
\hline 0.00 & 0.00 & 0.00 & 0.00 & 0.00 & 0.00 & 0.00 & 0.00 & 0.00 \\
\hline 0.00 & 0.00 & 0.00 & 0.33 & 0.00 & 0.33 & 0.00 & 0.00 & 0.00 \\
\hline 0.66 & 4.49 & 1.33 & 2.00 & 1.67 & 4.98 & 1.31 & 1.66 & 0.67 \\
\hline 0.00 & 0.00 & 0.00 & 0.00 & 0.00 & 0.00 & 0.00 & 0.00 & 0.00 \\
\hline
\end{tabular}




$\begin{array}{rrrrrrrrr}11.59 & 15.41 & 18.94 & 7.99 & 9.00 & 8.62 & 19.64 & 20.20 & 14.00 \\ 1.99 & 3.85 & 1.33 & 3.33 & 4.33 & 5.64 & 3.93 & 2.32 & 1.33 \\ 0.00 & 0.64 & 0.33 & 0.67 & 0.33 & 0.00 & 0.33 & 0.00 & 0.00 \\ 0.33 & 0.00 & 0.00 & 0.33 & 0.00 & 0.66 & 0.00 & 0.00 & 0.00 \\ 14.57 & 19.58 & 6.15 & 17.80 & 9.83 & 14.43 & 7.53 & 10.43 & 14.00 \\ 0.99 & 0.32 & 0.66 & 1.33 & 1.33 & 0.66 & 1.31 & 0.00 & 0.67 \\ 0.00 & 0.00 & 0.33 & 0.33 & 0.00 & 0.00 & 0.00 & 0.00 & 0.33 \\ 1.66 & 1.93 & 1.00 & 0.33 & 1.00 & 1.00 & 1.31 & 1.66 & 3.33 \\ 0.33 & 0.00 & 0.00 & 0.00 & 0.67 & 0.00 & 0.00 & 0.00 & 0.33 \\ 1.99 & 0.64 & 0.33 & 1.00 & 1.00 & 0.33 & 0.00 & 0.00 & 2.67 \\ 0.99 & 0.00 & 0.00 & 0.67 & 0.33 & 0.66 & 0.65 & 0.00 & 0.00 \\ 3.64 & 5.46 & 5.65 & 4.66 & 1.33 & 1.33 & 2.62 & 3.31 & 2.33 \\ 0.00 & 0.00 & 1.33 & 0.00 & 0.00 & 0.00 & 0.00 & 3.31 & 0.00 \\ 0.00 & 0.00 & 1.33 & 0.00 & 0.33 & 0.33 & 0.98 & 1.99 & 0.00\end{array}$




\begin{tabular}{|c|c|c|c|c|c|c|c|c|}
\hline 9.85 & 10.05 & 10.15 & 10.21 & 10.245 & 10.45 & 11.05 & 11.15 & 11.25 \\
\hline 1486 & 1535 & 1560 & 1575 & 1585 & 1634 & 1782 & 1806 & 1831 \\
\hline 0.33 & 0.33 & 0.33 & 0.66 & 1.66 & 1.33 & 0.33 & 1.66 & 2.33 \\
\hline 2.30 & 1.00 & 0.83 & 0.00 & 0.33 & 0.33 & 0.66 & 0.33 & 0.33 \\
\hline 0.00 & 0.33 & 0.00 & 0.66 & 0.00 & 0.67 & 0.00 & 0.33 & 0.00 \\
\hline 0.00 & 0.00 & 0.83 & 0.00 & 1.99 & 0.00 & 0.00 & 0.33 & 0.00 \\
\hline 1.64 & 0.00 & 0.00 & 0.66 & 1.00 & 0.33 & 0.66 & 0.67 & 1.66 \\
\hline 0.00 & 0.00 & 0.00 & 0.00 & 0.00 & 0.00 & 0.00 & 0.00 & 0.00 \\
\hline 0.66 & 1.33 & 0.33 & 2.30 & 3.65 & 1.67 & 0.33 & 1.66 & 1.33 \\
\hline 0.00 & 0.00 & 0.50 & 0.66 & 0.33 & 0.00 & 0.33 & 0.00 & 0.00 \\
\hline 0.00 & 0.00 & 0.00 & 0.00 & 0.00 & 0.00 & 0.00 & 0.00 & 0.00 \\
\hline 0.16 & 1.00 & 0.99 & 0.66 & 0.83 & 1.00 & 0.99 & 0.33 & 1.00 \\
\hline 0.33 & 0.33 & 0.00 & 0.00 & 0.17 & 0.00 & 1.32 & 0.00 & 0.17 \\
\hline 0.00 & 0.00 & 0.00 & 0.00 & 0.00 & 0.00 & 0.00 & 1.33 & 0.00 \\
\hline 0.00 & 0.00 & 0.33 & 0.00 & 0.00 & 0.00 & 0.00 & 0.00 & 0.67 \\
\hline 0.00 & 0.00 & 0.66 & 0.66 & 1.33 & 0.33 & 0.99 & 0.00 & 2.00 \\
\hline 4.60 & 2.00 & 2.98 & 7.55 & 6.64 & 1.33 & 1.81 & 0.67 & 3.99 \\
\hline 0.00 & 0.00 & 0.00 & 0.66 & 0.00 & 0.00 & 0.00 & 0.33 & 0.00 \\
\hline 0.00 & 1.00 & 0.00 & 0.00 & 0.66 & 0.67 & 1.98 & 0.33 & 0.00 \\
\hline 2.30 & 4.16 & 5.12 & 3.12 & 3.32 & 4.67 & 1.48 & 2.50 & 2.16 \\
\hline 5.58 & 0.67 & 2.98 & 4.93 & 2.66 & 4.67 & 2.31 & 10.32 & 8.99 \\
\hline 0.00 & 0.00 & 0.33 & 0.16 & 0.00 & 0.00 & 0.00 & 0.00 & 0.00 \\
\hline 0.66 & 2.00 & 1.49 & 2.30 & 1.00 & 2.67 & 3.62 & 1.50 & 3.33 \\
\hline 0.66 & 0.00 & 0.00 & 0.00 & 0.33 & 1.67 & 0.33 & 0.00 & 0.00 \\
\hline 2.63 & 5.99 & 1.98 & 1.64 & 0.66 & 1.33 & 2.31 & 4.83 & 3.33 \\
\hline 0.33 & 0.17 & 0.00 & 0.00 & 0.00 & 0.00 & 0.00 & 0.00 & 0.00 \\
\hline 0.16 & 0.00 & 0.00 & 0.33 & 0.33 & 0.00 & 0.00 & 0.00 & 0.33 \\
\hline 1.97 & 0.33 & 0.99 & 0.49 & 0.66 & 2.33 & 1.32 & 0.50 & 0.83 \\
\hline 0.00 & 0.00 & 0.00 & 0.00 & 0.00 & 0.00 & 0.00 & 0.00 & 0.00 \\
\hline 1.48 & 1.66 & 0.83 & 0.99 & 2.49 & 1.33 & 2.80 & 1.16 & 2.66 \\
\hline 12.48 & 9.65 & 2.98 & 4.11 & 2.49 & 6.50 & 5.93 & 4.33 & 7.32 \\
\hline 1.64 & 4.33 & 1.65 & 2.96 & 3.65 & 2.00 & 6.59 & 1.00 & 3.00 \\
\hline 0.00 & 0.00 & 0.17 & 0.00 & 0.00 & 0.00 & 0.00 & 0.33 & 0.00 \\
\hline 1.31 & 0.67 & 0.99 & 0.66 & 0.83 & 0.33 & 1.81 & 0.67 & 1.33 \\
\hline 0.99 & 1.33 & 0.00 & 2.63 & 2.49 & 1.83 & 1.32 & 1.66 & 3.99 \\
\hline 0.99 & 1.66 & 0.66 & 0.99 & 1.16 & 1.50 & 1.32 & 1.00 & 0.00 \\
\hline 0.00 & 0.00 & 0.00 & 0.00 & 0.00 & 0.00 & 0.00 & 0.00 & 0.00 \\
\hline 0.00 & 0.00 & 0.00 & 0.00 & 0.00 & 0.00 & 0.00 & 0.00 & 0.00 \\
\hline 0.00 & 0.00 & 0.00 & 0.00 & 0.00 & 0.00 & 0.00 & 0.00 & 0.00 \\
\hline 0.00 & 0.00 & 0.33 & 0.00 & 0.00 & 0.00 & 0.00 & 0.00 & 0.00 \\
\hline 0.33 & 1.66 & 2.31 & 0.66 & 0.66 & 0.67 & 1.98 & 0.67 & 1.00 \\
\hline 0.00 & 0.00 & 0.00 & 0.00 & 0.00 & 0.00 & 0.00 & 0.00 & 0.00 \\
\hline 0.00 & 0.00 & 0.00 & 0.00 & 0.00 & 0.00 & 0.00 & 0.00 & 0.00 \\
\hline 0.33 & 0.00 & 0.00 & 0.00 & 0.00 & 0.00 & 0.00 & 0.00 & 0.00 \\
\hline 0.00 & 0.00 & 0.00 & 0.00 & 0.00 & 0.00 & 0.00 & 0.00 & 0.00 \\
\hline 0.00 & 0.00 & 0.00 & 0.00 & 0.00 & 0.00 & 0.00 & 0.00 & 0.00 \\
\hline 0.00 & 0.00 & 0.00 & 0.00 & 0.00 & 0.00 & 0.00 & 0.00 & 0.00 \\
\hline 0.00 & 0.67 & 0.00 & 0.00 & 0.33 & 0.00 & 0.00 & 0.00 & 0.67 \\
\hline 2.30 & 0.00 & 1.65 & 3.94 & 2.66 & 0.33 & 0.99 & 1.66 & 2.00 \\
\hline 0.00 & 0.00 & 0.33 & 0.33 & 0.00 & 0.00 & 0.00 & 0.00 & 0.00 \\
\hline
\end{tabular}




$\begin{array}{rrrrrrrrr}22.00 & 7.32 & 6.61 & 9.20 & 12.29 & 15.67 & 16.14 & 12.98 & 5.32 \\ 2.30 & 1.00 & 4.30 & 4.93 & 0.66 & 1.00 & 0.33 & 2.00 & 4.33 \\ 0.33 & 0.00 & 0.00 & 0.00 & 0.00 & 1.00 & 0.00 & 0.00 & 0.33 \\ 0.00 & 0.33 & 0.33 & 0.00 & 0.00 & 0.00 & 0.00 & 0.00 & 0.00 \\ 10.51 & 23.29 & 27.11 & 18.06 & 14.45 & 16.67 & 8.73 & 20.47 & 9.32 \\ 0.66 & 0.67 & 0.00 & 0.00 & 0.00 & 0.33 & 0.00 & 0.33 & 0.67 \\ 0.00 & 0.00 & 0.33 & 0.00 & 0.00 & 0.00 & 0.33 & 0.00 & 0.00 \\ 0.99 & 2.33 & 0.66 & 1.64 & 3.65 & 1.33 & 2.31 & 0.67 & 3.33 \\ 0.00 & 0.33 & 2.31 & 0.33 & 0.66 & 0.33 & 0.00 & 1.00 & 0.00 \\ 2.63 & 0.00 & 0.33 & 3.28 & 0.00 & 0.33 & 2.97 & 1.00 & 1.00 \\ 0.99 & 1.33 & 0.33 & 0.00 & 0.66 & 0.67 & 0.66 & 1.66 & 1.33 \\ 2.96 & 3.99 & 3.97 & 3.28 & 1.99 & 3.00 & 4.28 & 3.33 & 2.33 \\ 0.00 & 0.00 & 1.32 & 0.00 & 0.66 & 0.67 & 0.66 & 0.00 & 0.00 \\ 0.33 & 1.00 & 0.66 & 0.00 & 0.00 & 0.67 & 0.99 & 0.00 & 0.33\end{array}$




\begin{tabular}{|c|c|c|c|c|c|c|c|c|}
\hline 11.45 & 11.65 & 11.77 & 11.8 & 12.06 & 12.26 & 12.46 & 12.66 & $\begin{array}{r}12.86 \\
2228\end{array}$ \\
\hline 1880 & 1930 & 1959 & 1966 & 2031 & 2080 & 2129 & 2178 & \\
\hline 1.33 & 1.00 & 0.67 & 0.00 & 2.31 & 1.99 & 1.32 & 0.67 & 0.33 \\
\hline 0.17 & 0.33 & 0.33 & 0.00 & 0.66 & 0.17 & 0.00 & 0.17 & 0.50 \\
\hline 0.00 & 0.00 & 0.00 & 0.00 & 0.00 & 0.00 & 0.00 & 0.00 & 0.00 \\
\hline 0.00 & 0.00 & 0.00 & 0.00 & 0.00 & 0.00 & 0.00 & 0.00 & 0.00 \\
\hline 1.33 & 0.67 & 0.33 & 1.00 & 0.00 & 0.33 & 0.00 & 1.67 & 0.67 \\
\hline 0.00 & 0.00 & 0.00 & 0.00 & 0.00 & 0.00 & 0.00 & 0.00 & 0.00 \\
\hline 0.00 & 0.00 & 0.33 & 3.00 & 1.65 & 1.33 & 0.00 & 1.33 & 0.33 \\
\hline 0.33 & 0.83 & 0.17 & 1.00 & 0.16 & 0.33 & 0.99 & 0.50 & 1.16 \\
\hline 0.00 & 0.00 & 0.00 & 0.00 & 0.00 & 0.00 & 0.00 & 0.00 & 0.00 \\
\hline 0.33 & 1.00 & 1.67 & 1.00 & 1.65 & 0.33 & 0.82 & 0.33 & 0.83 \\
\hline 0.50 & 0.00 & 0.00 & 0.00 & 0.00 & 0.00 & 0.00 & 0.00 & 0.00 \\
\hline 0.00 & 0.00 & 0.00 & 0.67 & 0.00 & 0.00 & 0.00 & 0.67 & 0.00 \\
\hline 0.00 & 0.67 & 0.00 & 0.00 & 0.00 & 0.66 & 0.00 & 0.00 & 1.00 \\
\hline 0.67 & 1.33 & 0.33 & 2.50 & 1.65 & 1.66 & 0.66 & 1.67 & 2.33 \\
\hline 1.16 & 1.33 & 0.67 & 0.33 & 0.66 & 0.33 & 0.00 & 0.67 & 1.00 \\
\hline 0.00 & 0.00 & 0.00 & 0.00 & 0.00 & 0.00 & 0.00 & 0.00 & 0.00 \\
\hline 0.67 & 0.00 & 0.33 & 0.00 & 0.00 & 0.66 & 0.00 & 0.33 & 0.33 \\
\hline 2.00 & 4.17 & 3.33 & 3.33 & 2.97 & 3.32 & 3.13 & 3.17 & 2.00 \\
\hline 4.66 & 8.33 & 4.33 & 1.00 & 5.27 & 2.65 & 1.97 & 2.67 & 3.66 \\
\hline 0.00 & 0.00 & 0.00 & 0.17 & 0.16 & 0.00 & 0.33 & 0.00 & 0.67 \\
\hline 2.16 & 0.67 & 2.17 & 2.00 & 4.61 & 2.32 & 2.14 & 3.00 & 1.00 \\
\hline 0.33 & 0.00 & 0.00 & 0.67 & 0.33 & 0.00 & 0.33 & 0.00 & 0.67 \\
\hline 4.99 & 0.33 & 1.00 & 3.00 & 4.94 & 2.32 & 2.30 & 4.33 & 4.33 \\
\hline 0.67 & 0.00 & 0.50 & 0.00 & 0.16 & 0.00 & 0.00 & 0.67 & 0.17 \\
\hline 0.00 & 0.33 & 0.67 & 0.00 & 0.16 & 0.00 & 0.00 & 0.00 & 0.00 \\
\hline 1.66 & 1.83 & 1.17 & 3.00 & 1.65 & 0.17 & 0.00 & 0.67 & 0.33 \\
\hline 1.66 & 0.67 & 0.00 & 0.33 & 0.99 & 0.00 & 0.00 & 0.33 & 3.49 \\
\hline 2.00 & 1.50 & 0.67 & 1.17 & 1.48 & 0.50 & 0.99 & 1.83 & 1.00 \\
\hline 5.99 & 3.33 & 3.67 & 4.33 & 2.80 & 5.64 & 2.80 & 5.33 & 2.50 \\
\hline 4.33 & 5.33 & 2.33 & 3.00 & 2.97 & 1.33 & 4.28 & 4.67 & 2.00 \\
\hline 0.00 & 0.00 & 0.33 & 0.00 & 0.00 & 0.33 & 0.33 & 0.00 & 0.0 \\
\hline 0.67 & 1.83 & 2.00 & 1.33 & 0.99 & 1.16 & 0.99 & 2.50 & 2.33 \\
\hline 2.50 & 2.00 & 1.67 & 0.67 & 1.48 & 1.33 & 3.29 & 1.67 & 2.33 \\
\hline 0.33 & 0.67 & 0.17 & 0.67 & 0.33 & 0.50 & 0.66 & 1.17 & 0.67 \\
\hline 0.00 & 0.00 & 0.00 & 0.00 & 0.00 & 0.00 & 0.00 & 0.00 & 0.00 \\
\hline 0.00 & 0.00 & 0.00 & 0.00 & 0.00 & 0.00 & 0.00 & 0.00 & 0.00 \\
\hline 0.00 & 0.00 & 0.00 & 0.00 & 0.00 & 0.00 & 0.00 & 0.00 & 0.00 \\
\hline 0.00 & 0.00 & 0.00 & 0.00 & 0.33 & 0.00 & 0.00 & 0.00 & 0.00 \\
\hline 1.33 & 0.33 & 0.67 & 2.00 & 1.32 & 1.66 & 1.97 & 0.67 & 0.67 \\
\hline 0.00 & 0.00 & 0.00 & 0.00 & 0.00 & 0.00 & 0.00 & 0.00 & 0.00 \\
\hline 0.00 & 0.00 & 0.00 & 0.00 & 0.00 & 0.00 & 0.00 & 0.00 & 0.00 \\
\hline 0.00 & 0.00 & 0.00 & 0.00 & 0.00 & 0.00 & 0.00 & 0.00 & 0.00 \\
\hline 0.00 & 0.00 & 0.00 & 0.00 & 0.00 & 0.00 & 0.00 & 0.00 & 0.00 \\
\hline 0.00 & 0.00 & 0.00 & 0.00 & 0.00 & 0.33 & 0.00 & 0.00 & \\
\hline 0.00 & 0.00 & 0.00 & 0.00 & 0.00 & 0.00 & 0.00 & 0.00 & 0.00 \\
\hline 0.00 & 0.67 & 0.33 & 0.67 & 0.00 & 0.00 & 0.99 & 0.33 & \\
\hline 1.00 & 1.33 & 3.67 & 2.33 & 2.97 & 1.00 & 6.25 & 3.67 & \\
\hline 0.00 & 0.00 & 0.00 & 0.00 & 0.00 & 0.00 & 0.00 & 0.00 & \\
\hline
\end{tabular}




$\begin{array}{rrrrrrrrr}20.30 & 12.00 & 4.33 & 8.33 & 7.91 & 8.29 & 7.24 & 17.33 & 7.99 \\ 3.33 & 4.67 & 23.00 & 6.00 & 14.17 & 13.93 & 24.34 & 6.33 & 2.66 \\ 1.00 & 0.33 & 0.33 & 0.00 & 0.33 & 0.00 & 0.00 & 0.00 & 0.33 \\ 0.33 & 0.00 & 0.00 & 0.00 & 0.00 & 0.00 & 1.64 & 0.00 & 1.33 \\ 15.31 & 20.83 & 17.67 & 22.67 & 9.39 & 14.26 & 15.13 & 15.17 & 28.95 \\ 0.00 & 0.33 & 0.00 & 1.00 & 0.00 & 0.33 & 0.33 & 0.00 & 0.00 \\ 0.00 & 0.67 & 0.00 & 1.00 & 0.99 & 0.66 & 0.00 & 0.00 & 0.67 \\ 1.00 & 0.67 & 2.00 & 2.00 & 0.66 & 1.66 & 0.99 & 1.33 & 0.33 \\ 0.67 & 0.33 & 0.00 & 0.00 & 0.66 & 0.00 & 0.00 & 0.67 & 0.33 \\ 0.67 & 2.00 & 2.00 & 0.33 & 1.32 & 2.99 & 0.00 & 0.00 & 0.00 \\ 0.00 & 1.33 & 0.33 & 1.33 & 0.00 & 0.33 & 0.00 & 0.00 & 0.33 \\ 2.33 & 4.67 & 2.33 & 3.00 & 1.65 & 4.98 & 3.29 & 3.33 & 2.00 \\ 0.50 & 0.00 & 0.00 & 0.00 & 0.99 & 0.50 & 0.66 & 0.33 & 0.67 \\ 0.00 & 0.33 & 0.67 & 0.33 & 0.00 & 1.66 & 0.33 & 0.00 & 0.00\end{array}$




\begin{tabular}{|c|c|c|c|c|c|c|c|c|}
\hline 13.06 & 13.21 & 13.27 & 13.41 & 13.46 & 13.61 & 13.78 & 14.01 & 14.21 \\
\hline 2277 & 2314 & 2329 & 2363 & 2375 & 2412 & 2454 & 2511 & 2560 \\
\hline 0.99 & 0.33 & 0.66 & 0.33 & 0.00 & 1.67 & 1.67 & 0.33 & 0.33 \\
\hline 0.17 & 0.33 & 0.33 & 0.00 & 0.00 & 0.33 & 0.67 & 0.33 & 0.00 \\
\hline 0.00 & 0.00 & 0.33 & 0.00 & 0.17 & 1.00 & 0.00 & 0.00 & 0.33 \\
\hline 0.00 & 0.00 & 0.00 & 0.33 & 0.00 & 0.50 & 0.67 & 0.33 & 1.00 \\
\hline 0.99 & 1.33 & 0.00 & 0.00 & 1.66 & 0.33 & 1.33 & 0.33 & 1.00 \\
\hline 0.00 & 0.00 & 0.00 & 0.00 & 0.00 & 0.00 & 0.00 & 0.00 & 0.00 \\
\hline 1.32 & 1.67 & 2.64 & 0.00 & 0.33 & 1.67 & 1.00 & 0.00 & 1.33 \\
\hline 0.33 & 0.83 & 0.00 & 0.33 & 0.33 & 0.00 & 0.67 & 0.67 & 0.66 \\
\hline 0.00 & 0.00 & 0.00 & 0.00 & 0.00 & 0.00 & 0.00 & 0.00 & 0.00 \\
\hline 0.50 & 0.17 & 0.50 & 0.16 & 0.33 & 0.33 & 0.50 & 0.00 & 0.83 \\
\hline 0.00 & 0.00 & 0.00 & 0.00 & 0.00 & 0.17 & 0.00 & 0.00 & 0.00 \\
\hline 0.00 & 0.00 & 0.00 & 0.00 & 0.00 & 2.33 & 0.67 & 0.00 & 0.00 \\
\hline 0.66 & 0.00 & 0.00 & 0.00 & 0.00 & 0.00 & 0.00 & 0.00 & 0.00 \\
\hline 0.66 & 0.67 & 1.16 & 0.33 & 0.50 & 0.00 & 0.33 & 1.66 & 0.66 \\
\hline 3.48 & 1.00 & 1.98 & 0.00 & 1.00 & 0.50 & 0.83 & 1.66 & 3.32 \\
\hline 0.00 & 0.00 & 0.00 & 0.00 & 0.00 & 0.50 & 0.00 & 0.00 & 0.00 \\
\hline 0.00 & 0.33 & 0.00 & 0.00 & 0.00 & 0.33 & 0.67 & 0.00 & 0.00 \\
\hline 1.32 & 1.00 & 2.64 & 2.30 & 1.00 & 2.33 & 2.83 & 3.00 & 2.82 \\
\hline 3.31 & 3.67 & 2.31 & 4.93 & 4.66 & 6.67 & 0.33 & 2.33 & 2.65 \\
\hline 0.00 & 0.33 & 0.50 & 0.16 & 0.00 & 0.00 & 1.00 & 0.33 & 0.00 \\
\hline 1.16 & 1.50 & 4.30 & 0.00 & 2.00 & 1.33 & 0.33 & 1.33 & 2.99 \\
\hline 0.00 & 0.33 & 0.00 & 0.00 & 0.33 & 0.00 & 0.00 & 0.33 & 0.00 \\
\hline 3.31 & 4.00 & 4.30 & 1.64 & 2.66 & 0.00 & 3.67 & 1.66 & 0.00 \\
\hline 0.83 & 0.67 & 0.17 & 0.00 & 0.00 & 0.67 & 0.67 & 0.00 & 0.00 \\
\hline 0.00 & 0.00 & 0.00 & 0.00 & 0.00 & 0.67 & 0.00 & 0.00 & 0.33 \\
\hline 0.17 & 0.67 & 0.66 & 0.66 & 1.33 & 2.00 & 1.50 & 0.17 & 0.50 \\
\hline 0.33 & 0.00 & 0.33 & 0.00 & 1.00 & 0.00 & 0.00 & 0.00 & 0.00 \\
\hline 0.33 & 0.50 & 0.17 & 0.33 & 0.00 & 1.67 & 1.83 & 2.33 & 1.33 \\
\hline 2.15 & 3.67 & 4.46 & 3.95 & 0.50 & 4.67 & 3.33 & 3.00 & 3.98 \\
\hline 3.64 & 2.00 & 2.98 & 0.66 & 2.00 & 3.00 & 2.67 & 2.66 & 2.99 \\
\hline 0.00 & 0.00 & 0.66 & 0.00 & 0.33 & 0.00 & 0.00 & 0.00 & 0.00 \\
\hline 2.65 & 2.67 & 1.32 & 0.00 & 1.33 & 1.00 & 1.17 & 0.83 & 0.83 \\
\hline 1.99 & 2.67 & 0.99 & 0.99 & 1.66 & 2.33 & 1.00 & 0.33 & 0.83 \\
\hline 0.66 & 0.17 & 1.65 & 0.00 & 1.33 & 0.83 & 0.50 & 2.33 & 0.83 \\
\hline 0.00 & 0.00 & 0.00 & 0.00 & 0.00 & 0.00 & 0.00 & 0.00 & 0.00 \\
\hline 0.00 & 0.00 & 0.00 & 0.00 & 0.00 & 0.00 & 0.00 & 0.00 & 0.00 \\
\hline 0.00 & 0.00 & 0.00 & 0.00 & 0.00 & 0.00 & 0.00 & 0.00 & 0.00 \\
\hline 0.00 & 0.00 & 0.00 & 0.00 & 0.00 & 0.00 & 0.00 & 0.00 & 0.00 \\
\hline 1.32 & 1.67 & 3.64 & 0.33 & 0.00 & 0.67 & 2.00 & 2.00 & 1.95 \\
\hline 0.00 & 0.00 & 0.00 & 0.00 & 0.00 & 0.00 & 0.00 & 0.00 & 0.00 \\
\hline 0.00 & 0.00 & 0.00 & 0.00 & 0.00 & 0.00 & 0.00 & 0.67 & 0.00 \\
\hline 0.00 & 0.33 & 0.00 & 0.00 & 0.00 & 0.00 & 0.00 & 0.00 & 0.00 \\
\hline 0.00 & 0.00 & 0.00 & 0.00 & 0.00 & 0.00 & 0.00 & 0.00 & 0.00 \\
\hline 0.00 & 0.00 & 0.00 & 0.00 & 0.00 & 0.00 & 0.00 & 0.33 & 0.00 \\
\hline 0.00 & 0.00 & 0.00 & 0.00 & 0.00 & 0.00 & 0.00 & 0.00 & 0.00 \\
\hline 0.00 & 0.00 & 0.33 & 0.00 & 1.00 & 0.00 & 0.67 & 0.67 & 3.32 \\
\hline 1.99 & 2.33 & 4.96 & 0.66 & 2.00 & 2.33 & 0.67 & 5.32 & 1.66 \\
\hline 0.00 & 0.00 & .00 & 0.00 & 0.00 & 0.00 & 0.00 & 0.00 & 0.00 \\
\hline
\end{tabular}




$\begin{array}{rrrrrrrrr}9.27 & 4.00 & 6.94 & 5.59 & 5.32 & 17.00 & 21.00 & 4.99 & 5.64 \\ 10.93 & 14.67 & 12.89 & 31.58 & 8.99 & 8.00 & 16.33 & 6.66 & 2.99 \\ 0.00 & 0.00 & 0.00 & 0.33 & 0.00 & 0.00 & 0.33 & 0.00 & 0.00 \\ 0.66 & 0.00 & 0.66 & 0.33 & 0.67 & 0.00 & 0.67 & 0.33 & 0.00 \\ 19.87 & 20.83 & 8.10 & 28.95 & 30.28 & 12.67 & 5.67 & 23.29 & 27.53 \\ 0.33 & 0.67 & 1.32 & 0.00 & 0.00 & 0.33 & 0.00 & 0.00 & 0.66 \\ 0.00 & 0.33 & 0.99 & 0.00 & 0.00 & 0.00 & 0.00 & 1.66 & 0.00 \\ 1.66 & 1.67 & 0.66 & 0.66 & 0.33 & 2.00 & 1.67 & 0.33 & 1.66 \\ 0.00 & 0.33 & 0.00 & 0.00 & 0.00 & 0.33 & 0.00 & 0.33 & 0.66 \\ 0.99 & 0.67 & 0.00 & 0.33 & 0.67 & 0.33 & 1.00 & 0.00 & 0.33 \\ 0.00 & 0.00 & 0.00 & 0.00 & 0.00 & 1.00 & 0.00 & 0.00 & 0.00 \\ 3.31 & 4.67 & 3.97 & 2.30 & 7.32 & 2.00 & 2.67 & 9.32 & 3.65 \\ 1.32 & 0.00 & 0.33 & 0.00 & 0.00 & 0.00 & 1.00 & 0.67 & 1.00 \\ 0.66 & 1.67 & 0.66 & 0.66 & 0.33 & 0.33 & 0.33 & 0.67 & 3.32\end{array}$




\begin{tabular}{|c|c|c|c|c|c|c|c|c|}
\hline 14.56 & 14.61 & 14.75 & 14.95 & 15.16 & 15.36 & 15.56 & 15.85 & $\begin{array}{r}16.06 \\
2900\end{array}$ \\
\hline 2626 & 2636 & 2661 & 2698 & 2737 & 2774 & 2810 & 2864 & 2902 \\
\hline 0.00 & 0.33 & 0.00 & 0.33 & 0.33 & 2.33 & 0.99 & 0.67 & 1.33 \\
\hline 0.00 & 0.66 & 0.67 & 0.33 & 1.32 & 1.00 & 0.66 & 0.00 & 0.17 \\
\hline 0.00 & 0.00 & 0.00 & 0.00 & 0.00 & 1.67 & 0.00 & 0.00 & 0.00 \\
\hline 0.00 & 0.00 & 0.00 & 0.00 & 0.00 & 1.33 & 0.00 & 0.00 & 0.00 \\
\hline 0.00 & 0.99 & 0.67 & 1.32 & 0.00 & 0.00 & 1.98 & 0.00 & 0.00 \\
\hline 0.00 & 0.00 & 0.00 & 0.00 & 0.00 & 0.00 & 0.00 & 0.00 & 0.00 \\
\hline 1.66 & 0.00 & 1.66 & 0.66 & 1.32 & 4.33 & 1.32 & 1.00 & 0.67 \\
\hline 1.00 & 0.00 & 0.33 & 0.00 & 0.83 & 0.00 & 1.32 & 0.00 & 0.00 \\
\hline 0.00 & 0.00 & 0.00 & 0.00 & 0.00 & 0.00 & 0.00 & 0.00 & 0.00 \\
\hline 0.83 & 0.16 & 0.17 & 0.99 & 0.17 & 0.50 & 0.83 & 0.00 & 1.33 \\
\hline 0.00 & 0.00 & 0.00 & 0.00 & 0.00 & 0.00 & 0.00 & 0.33 & 0.00 \\
\hline 0.33 & 0.00 & 0.00 & 0.17 & 0.00 & 1.33 & 0.00 & 0.00 & 0.67 \\
\hline 0.00 & 0.00 & 0.00 & 0.00 & 0.00 & 0.00 & 0.00 & 0.00 & 0.17 \\
\hline 0.50 & 0.33 & 0.67 & 1.32 & 0.99 & 0.00 & 0.66 & 0.33 & 0.83 \\
\hline 2.33 & 3.62 & 2.66 & 0.33 & 2.31 & 1.33 & 0.99 & 2.50 & 0.67 \\
\hline 0.00 & 0.00 & 0.00 & 0.00 & 0.00 & 0.67 & 0.00 & 0.00 & 0.00 \\
\hline 0.33 & 0.66 & 0.33 & 0.00 & 0.00 & 0.67 & 0.66 & 1.33 & 0.33 \\
\hline 1.16 & 3.62 & 2.66 & 1.49 & 1.82 & 3.50 & 3.80 & 1.00 & 2.83 \\
\hline 2.99 & 4.94 & 3.00 & 1.32 & 3.31 & 3.67 & 4.30 & 0.67 & 2.33 \\
\hline 0.00 & 0.00 & 0.00 & 0.00 & 0.00 & 0.00 & 0.00 & 0.00 & 0.50 \\
\hline 4.15 & 2.31 & 3.66 & 0.99 & 2.64 & 2.67 & 2.31 & 1.16 & 3.50 \\
\hline 0.33 & 0.33 & 0.00 & 0.33 & 0.00 & 0.00 & 0.00 & 0.33 & 0.33 \\
\hline 3.65 & 6.92 & 1.00 & 4.30 & 6.61 & 2.00 & 4.63 & 6.66 & 5.17 \\
\hline 1.00 & 0.16 & 0.67 & 0.33 & 0.00 & 0.33 & 0.66 & 0.00 & 0.17 \\
\hline 0.33 & 0.00 & 0.00 & 0.00 & 0.17 & 0.00 & 0.99 & 0.33 & 0.00 \\
\hline 0.83 & 0.82 & 2.33 & 1.82 & 1.82 & 0.50 & 1.65 & 1.50 & 0.83 \\
\hline 0.00 & 0.00 & 0.00 & 0.00 & 0.00 & 0.00 & 0.00 & 0.00 & 0.67 \\
\hline 1.50 & 1.98 & 1.83 & 4.30 & 1.98 & 0.33 & 1.49 & 2.16 & 2.50 \\
\hline 8.80 & 5.44 & 4.99 & 3.47 & 2.98 & 8.00 & 9.09 & 8.49 & 7.83 \\
\hline 0.33 & 2.97 & 1.66 & 4.30 & 1.65 & 2.00 & 3.64 & 2.66 & 4.67 \\
\hline 0.00 & 0.33 & 0.00 & 0.00 & 0.00 & 0.00 & 0.00 & 0.00 & 0.33 \\
\hline 0.00 & 0.99 & 1.66 & 1.49 & 1.82 & 2.00 & 2.15 & 3.00 & 3.33 \\
\hline 5.65 & 0.33 & 2.33 & 0.99 & 1.32 & 1.00 & 2.98 & 3.33 & 1.33 \\
\hline 2.16 & 1.32 & 0.00 & 0.33 & 1.98 & 1.33 & 1.65 & 1.83 & 1.17 \\
\hline 0.00 & 0.00 & 0.00 & 0.00 & 0.00 & 0.00 & 0.00 & 0.00 & 0.00 \\
\hline 0.00 & 0.00 & 0.00 & 0.00 & 0.00 & 0.00 & 0.00 & 0.00 & 0.00 \\
\hline 0.00 & 0.00 & 0.00 & 0.00 & 0.00 & 0.00 & 0.00 & 0.00 & 0.00 \\
\hline 0.00 & 0.00 & 0.00 & 0.00 & 0.00 & 0.00 & 0.00 & 0.00 & 0.00 \\
\hline 1.99 & 2.64 & 0.33 & 1.65 & 1.65 & 2.00 & 0.66 & 0.33 & 0.33 \\
\hline 0.00 & 0.00 & 0.00 & 0.00 & 0.00 & 0.00 & 0.00 & 0.00 & 0.00 \\
\hline 0.00 & 0.00 & 0.00 & 0.00 & 0.00 & 0.00 & 0.00 & 0.00 & 0.00 \\
\hline 0.00 & 0.00 & 0.00 & 0.00 & 0.00 & 0.00 & 0.00 & 0.00 & 0.00 \\
\hline 0.00 & 0.00 & 0.00 & 0.00 & 0.00 & 0.00 & 0.00 & 0.00 & 0.00 \\
\hline 0.00 & 0.00 & 0.00 & 0.00 & 0.00 & 0.00 & 0.00 & 0.00 & 0.00 \\
\hline 0.00 & 0.00 & 0.00 & 0.00 & 0.00 & 0.00 & 0.00 & 0.00 & 0.00 \\
\hline 0.00 & 0.33 & 0.00 & 0.00 & 0.33 & 0.00 & 0.00 & 0.00 & 1.67 \\
\hline 1.00 & 0.99 & 3.00 & 0.99 & 3.97 & 2.67 & 0.99 & 1.33 & 2.67 \\
\hline 0.00 & 0.00 & 0.00 & 0.00 & 0.00 & 0.00 & 0.00 & 0.00 & 0.00 \\
\hline
\end{tabular}




$\begin{array}{rrrrrrrrr}9.63 & 13.84 & 6.66 & 14.55 & 6.28 & 18.00 & 8.93 & 17.97 & 12.67 \\ 1.33 & 4.61 & 3.00 & 2.64 & 15.54 & 0.00 & 1.98 & 3.66 & 0.33 \\ 0.00 & 0.00 & 0.33 & 0.00 & 0.00 & 0.00 & 0.00 & 0.33 & 0.67 \\ 0.33 & 0.66 & 0.00 & 0.00 & 0.33 & 0.00 & 0.00 & 0.00 & 0.67 \\ 14.95 & 16.97 & 26.12 & 24.46 & 11.74 & 12.67 & 11.40 & 9.98 & 7.67 \\ 0.00 & 0.33 & 0.00 & 0.33 & 0.00 & 0.00 & 0.00 & 0.67 & 1.00 \\ 0.33 & 0.00 & 0.00 & 0.00 & 0.66 & 0.00 & 0.33 & 0.00 & 0.00 \\ 1.33 & 0.66 & 2.66 & 1.32 & 0.99 & 0.33 & 2.64 & 1.66 & 1.67 \\ 0.00 & 0.00 & 1.33 & 0.99 & 0.33 & 0.67 & 0.99 & 0.33 & 0.33 \\ 0.00 & 0.33 & 0.00 & 0.00 & 0.00 & 0.33 & 0.00 & 0.00 & 1.67 \\ 0.00 & 0.00 & 0.33 & 0.33 & 0.33 & 1.33 & 0.00 & 0.00 & 0.00 \\ 7.97 & 4.61 & 5.32 & 6.61 & 4.63 & 3.33 & 3.97 & 3.66 & 3.33 \\ 1.00 & 1.32 & 0.00 & 0.00 & 1.65 & 0.00 & 0.00 & 0.00 & 1.00 \\ 0.33 & 0.66 & 1.00 & 0.66 & 1.98 & 0.00 & 1.65 & 3.00 & 3.00\end{array}$




\begin{tabular}{|c|c|c|c|c|c|c|c|c|}
\hline 16.49 & 16.64 & 16.68 & 16.84 & 16.91 & 17.04 & 17.26 & 17.44 & $\begin{array}{r}17.64 \\
3193\end{array}$ \\
\hline 2981 & 3009 & 3016 & 3046 & 3058 & 3082 & 3123 & 3156 & 3193 \\
\hline 0.00 & 0.32 & 2.97 & 0.65 & 1.31 & 0.33 & 2.99 & 0.00 & 0.00 \\
\hline 0.67 & 0.65 & 0.00 & 0.00 & 0.98 & 0.16 & 0.00 & 0.33 & 0.00 \\
\hline 0.00 & 0.65 & 0.00 & 0.00 & 0.00 & 0.00 & 0.00 & 0.00 & 0.00 \\
\hline 0.00 & 0.65 & 0.00 & 0.00 & 0.65 & 0.00 & 0.33 & 0.00 & 0.00 \\
\hline 0.00 & 2.27 & 0.66 & 0.00 & 0.00 & 0.00 & 1.00 & 0.00 & 0.00 \\
\hline 0.00 & 0.00 & 0.00 & 0.00 & 0.00 & 0.00 & 0.00 & 0.00 & 0.00 \\
\hline 0.67 & 1.46 & 0.66 & 0.65 & 0.98 & 0.00 & 2.33 & 3.65 & 0.00 \\
\hline 0.00 & 0.00 & 0.83 & 0.00 & 0.98 & 0.00 & 0.66 & 0.00 & 0.67 \\
\hline 0.00 & 0.00 & 0.00 & 0.00 & 0.00 & 0.00 & 0.00 & 0.00 & 0.00 \\
\hline 0.67 & 0.16 & 0.17 & 0.65 & 0.00 & 0.33 & 0.50 & 0.50 & 0.33 \\
\hline 0.17 & 0.00 & 0.17 & 0.16 & 0.00 & 0.00 & 0.00 & 0.00 & 0.00 \\
\hline 0.00 & 1.30 & 0.00 & 0.65 & 0.00 & 0.00 & 0.00 & 0.00 & 0.00 \\
\hline 0.17 & 0.00 & 0.00 & 0.00 & 0.65 & 0.00 & 0.00 & 0.00 & 0.00 \\
\hline 0.67 & 0.00 & 0.66 & 1.30 & 0.65 & 1.31 & 2.16 & 0.33 & 3.00 \\
\hline 3.67 & 4.06 & 1.98 & 0.81 & 0.33 & 6.86 & 1.33 & 1.00 & 3.00 \\
\hline 0.00 & 2.60 & 0.00 & 0.00 & 0.00 & 0.00 & 0.00 & 0.00 & 0.00 \\
\hline 0.00 & 0.00 & 0.00 & 0.00 & 0.00 & 0.33 & 0.33 & 0.00 & 0.67 \\
\hline 2.17 & 3.90 & 2.31 & 2.11 & 3.27 & 1.47 & 3.32 & 2.16 & 3.16 \\
\hline 3.33 & 5.19 & 7.26 & 4.55 & 2.62 & 4.58 & 5.32 & 7.96 & 1.66 \\
\hline 0.00 & 0.00 & 0.00 & 0.00 & 0.00 & 0.49 & 0.00 & 1.00 & 0.17 \\
\hline 1.00 & 1.30 & 2.64 & 0.32 & 2.13 & 0.98 & 2.33 & 2.99 & 2.83 \\
\hline 0.67 & 0.00 & 0.00 & 0.00 & 0.49 & 0.00 & 0.33 & 0.00 & 0.33 \\
\hline 2.00 & 1.62 & 2.97 & 3.90 & 2.62 & 2.29 & 6.64 & 2.99 & 8.99 \\
\hline 0.17 & 0.00 & 0.00 & 0.00 & 0.00 & 0.16 & 0.17 & 0.00 & 0.00 \\
\hline 2.00 & 0.65 & 0.66 & 0.32 & 0.65 & 0.00 & 0.33 & 0.33 & 1.33 \\
\hline 1.33 & 0.49 & 0.99 & 0.49 & 0.65 & 0.65 & 1.33 & 0.83 & 2.50 \\
\hline 0.00 & 0.00 & 0.66 & 0.32 & 0.00 & 0.00 & 1.00 & 0.00 & 0.00 \\
\hline 1.17 & 1.46 & 1.49 & 1.62 & 1.47 & 0.65 & 1.00 & 2.82 & 1.16 \\
\hline 6.00 & 3.57 & 4.13 & 5.84 & 5.89 & 5.72 & 5.48 & 9.29 & 4.33 \\
\hline 0.67 & 2.27 & 3.63 & 3.57 & 1.96 & 2.29 & 2.66 & 4.31 & 3.00 \\
\hline 0.00 & 0.00 & 0.00 & 0.00 & 0.16 & 0.00 & 0.66 & 0.00 & 0.00 \\
\hline 1.33 & 1.30 & 0.50 & 0.81 & 0.49 & 0.98 & 0.33 & 1.16 & 1.66 \\
\hline 1.33 & 1.30 & 2.31 & 1.30 & 5.56 & 0.65 & 4.32 & 1.99 & 2.66 \\
\hline 1.33 & 1.62 & 0.83 & 0.65 & 0.00 & 0.00 & 0.33 & 1.00 & 1.33 \\
\hline 0.00 & 0.00 & 0.00 & 0.00 & 0.00 & 0.00 & 0.00 & 0.00 & 0.00 \\
\hline 0.00 & 0.00 & 0.00 & 0.00 & 0.00 & 0.00 & 0.00 & 0.00 & 0.00 \\
\hline 0.00 & 0.00 & 0.00 & 0.00 & 0.00 & 0.33 & 0.00 & 0.00 & 0.00 \\
\hline 0.00 & 0.00 & 0.00 & 0.00 & 0.00 & 0.00 & 0.00 & 0.00 & 0.00 \\
\hline 1.00 & 1.62 & 0.33 & 3.57 & 0.65 & 0.33 & 1.99 & 2.99 & 1.33 \\
\hline 0.00 & 0.00 & 0.00 & 0.00 & 0.00 & 0.00 & 0.00 & 0.00 & 0.00 \\
\hline 0.00 & 0.00 & 0.00 & 0.00 & 0.00 & 0.00 & 0.00 & 0.00 & 0.00 \\
\hline 0.00 & 0.00 & 0.00 & 0.00 & 0.00 & 0.00 & 0.33 & 0.00 & 0.00 \\
\hline 0.00 & 0.00 & 0.00 & 0.00 & 0.00 & 0.00 & 0.00 & 0.00 & 0.00 \\
\hline 0.00 & 0.00 & 0.00 & 0.00 & 0.00 & 0.00 & 0.00 & 0.00 & 0.00 \\
\hline 0.00 & 0.00 & 0.00 & 0.00 & 0.00 & 0.33 & 0.00 & 0.00 & 0.00 \\
\hline 1.00 & 0.00 & 0.99 & 0.32 & 0.65 & 0.00 & 0.33 & 0.00 & 1.00 \\
\hline 1.33 & 3.57 & 0.33 & 2.27 & 5.56 & 1.96 & 1.33 & 1.99 & 1.66 \\
\hline 0.00 & 0.00 & 0.00 & 0.00 & 0.00 & 0.00 & 0.00 & 0.00 & 0.00 \\
\hline
\end{tabular}




$\begin{array}{rrrrrrrrr}16.00 & 24.03 & 15.51 & 21.43 & 19.97 & 29.74 & 14.95 & 23.55 & 20.63 \\ 1.00 & 0.00 & 10.89 & 14.94 & 7.20 & 2.94 & 4.65 & 2.65 & 4.66 \\ 0.67 & 0.32 & 0.33 & 0.00 & 0.00 & 0.33 & 0.33 & 0.00 & 0.00 \\ 0.67 & 0.00 & 0.33 & 0.00 & 0.00 & 0.00 & 1.99 & 0.00 & 0.33 \\ 16.67 & 8.77 & 11.88 & 7.47 & 12.44 & 11.76 & 2.99 & 8.46 & 9.65 \\ 0.00 & 0.32 & 0.33 & 0.00 & 0.33 & 0.33 & 0.00 & 0.00 & 0.00 \\ 0.33 & 0.32 & 0.99 & 0.00 & 0.65 & 0.33 & 6.64 & 0.00 & 0.00 \\ 0.00 & 1.95 & 2.31 & 0.65 & 1.31 & 1.31 & 0.66 & 3.32 & 0.67 \\ 0.67 & 0.32 & 1.98 & 0.32 & 0.65 & 0.65 & 1.00 & 1.00 & 2.00 \\ 2.67 & 0.00 & 0.00 & 0.65 & 1.31 & 0.00 & 0.33 & 0.33 & 1.00 \\ 1.00 & 0.00 & 0.33 & 0.00 & 0.00 & 0.00 & 0.33 & 0.33 & 0.33 \\ 5.67 & 3.25 & 4.95 & 4.22 & 1.96 & 3.59 & 0.66 & 2.32 & 3.33 \\ 0.00 & 0.00 & 0.00 & 0.00 & 0.00 & 0.00 & 0.00 & 0.00 & 0.67 \\ 0.33 & 0.00 & 0.66 & 0.32 & 0.65 & 0.00 & 0.66 & 0.00 & 0.00\end{array}$




\begin{tabular}{|c|c|c|c|c|c|c|c|c|}
\hline 17.84 & 18.06 & 18.22 & 18.28 & 18.38 & 18.42 & $\begin{array}{r}18.62 \\
2372\end{array}$ & 18.82 & $\begin{array}{r}19.02 \\
3446\end{array}$ \\
\hline 3229 & 3270 & 3299 & 3310 & 3329 & 3336 & 3373 & 3410 & \\
\hline 0.33 & 0.00 & 1.67 & 2.66 & 1.33 & 0.00 & 0.33 & 0.65 & 0.00 \\
\hline 0.00 & 0.00 & 0.00 & 1.00 & 0.33 & 0.67 & 0.00 & 0.32 & 0.00 \\
\hline 0.00 & 0.00 & 0.00 & 0.00 & 0.00 & 0.00 & 0.33 & 0.65 & 0.00 \\
\hline 0.00 & 0.00 & 0.00 & 0.00 & 0.00 & 0.00 & 0.33 & 0.00 & 0.00 \\
\hline 0.00 & 0.66 & 0.00 & 0.00 & 1.66 & 1.33 & 0.00 & 0.00 & 1.00 \\
\hline 0.00 & 0.00 & 0.00 & 0.00 & 0.00 & 0.00 & 0.00 & 0.00 & 0.00 \\
\hline 0.33 & 0.33 & 2.00 & 3.65 & 1.66 & 1.33 & 1.33 & 0.65 & 1.33 \\
\hline 0.17 & 0.33 & 0.33 & 0.66 & 1.00 & 0.67 & 0.66 & 0.32 & 0.00 \\
\hline 0.00 & 0.00 & 0.00 & 0.00 & 0.00 & 0.00 & 0.00 & 0.00 & 0.00 \\
\hline 0.83 & 0.83 & 1.33 & 1.16 & 0.50 & 0.33 & 1.33 & 0.65 & 0.00 \\
\hline 0.00 & 0.00 & 0.33 & 0.00 & 0.17 & 0.00 & 0.00 & 0.00 & 0.67 \\
\hline 0.00 & 0.00 & 0.00 & 0.00 & 0.00 & 0.00 & 0.66 & 0.00 & 0.00 \\
\hline 0.00 & 0.66 & 0.00 & 0.00 & 0.00 & 0.00 & 0.00 & 0.00 & 0.00 \\
\hline 1.00 & 0.66 & 1.33 & 0.00 & 0.00 & 0.00 & 0.00 & 0.00 & 2.67 \\
\hline 1.33 & 1.33 & 0.50 & 0.33 & 2.00 & 0.67 & 0.66 & 0.65 & 2.67 \\
\hline 0.00 & 0.00 & 0.00 & 0.00 & 0.00 & 0.00 & 0.33 & 0.00 & 0.00 \\
\hline 0.00 & 0.33 & 0.00 & 0.33 & 0.33 & 0.33 & 0.00 & 0.00 & 0.00 \\
\hline 1.50 & 4.48 & 2.17 & 1.66 & 2.66 & 2.83 & 3.82 & 2.27 & 2.83 \\
\hline 0.67 & 5.97 & 4.67 & 6.98 & 1.66 & 1.00 & 5.65 & 2.91 & 2.33 \\
\hline 0.00 & 0.00 & 0.33 & 0.66 & 0.17 & 1.00 & 0.00 & 0.81 & 0.33 \\
\hline 1.33 & 1.49 & 4.17 & 2.33 & 0.33 & 1.16 & 1.99 & 3.07 & 3.33 \\
\hline 0.33 & 0.66 & 0.00 & 0.33 & 0.67 & 0.33 & 0.00 & 0.65 & 0.17 \\
\hline 4.99 & 2.32 & 1.67 & 5.65 & 4.99 & 1.00 & 2.33 & 1.94 & 2.67 \\
\hline 0.00 & 0.33 & 0.00 & 0.00 & 0.33 & 0.00 & 0.00 & 0.00 & 0.00 \\
\hline 0.67 & 0.00 & 0.67 & 0.17 & 0.00 & 0.67 & 0.00 & 0.49 & 0.00 \\
\hline 1.16 & 1.99 & 1.17 & 1.16 & 0.67 & 0.50 & 1.16 & 0.81 & 1.83 \\
\hline 0.00 & 1.66 & 0.67 & 0.00 & 0.00 & 0.00 & 0.00 & 0.00 & 0.67 \\
\hline 2.83 & 1.16 & 0.83 & 1.66 & 1.16 & 2.66 & 1.33 & 1.29 & 1.17 \\
\hline 3.66 & 5.47 & 4.33 & 9.63 & 5.49 & 11.31 & 4.49 & 5.34 & 9.00 \\
\hline 2.66 & 3.98 & 2.33 & 3.99 & 3.33 & 3.66 & 6.31 & 3.56 & 2.33 \\
\hline 0.00 & 0.00 & 0.00 & 0.00 & 0.00 & 0.00 & 0.00 & 0.00 & 0.00 \\
\hline 1.83 & 0.17 & 0.83 & 1.33 & 0.83 & 0.33 & 2.16 & 1.78 & 2.17 \\
\hline 2.66 & 2.16 & 4.83 & 3.32 & 0.33 & 0.00 & 0.33 & 1.62 & 0.67 \\
\hline 0.67 & 1.33 & 0.67 & 0.66 & 1.66 & 1.16 & 1.00 & 0.97 & 1.67 \\
\hline 0.00 & 0.00 & 0.00 & 0.00 & 0.00 & 0.00 & 0.00 & 0.00 & 0.00 \\
\hline 0.00 & 0.00 & 0.00 & 0.00 & 0.00 & 0.00 & 0.00 & 0.00 & 0.00 \\
\hline 0.00 & 0.00 & 0.00 & 0.00 & 0.00 & 0.00 & 0.00 & 0.00 & 0.00 \\
\hline 0.00 & 0.00 & 0.00 & 0.00 & 0.00 & 0.00 & 0.00 & 0.00 & 0.00 \\
\hline 2.00 & 1.33 & 1.33 & 0.66 & 2.00 & 2.33 & 1.33 & 1.62 & 0.67 \\
\hline 0.00 & 0.00 & 0.00 & 0.00 & 0.00 & 0.00 & 0.00 & 0.00 & 0.00 \\
\hline 0.00 & 0.00 & 0.00 & 0.00 & 0.33 & 0.00 & 0.00 & 0.00 & 0.00 \\
\hline 0.00 & 0.00 & 0.00 & 0.00 & 0.00 & 0.00 & 0.00 & 0.00 & 0.00 \\
\hline 0.00 & 0.00 & 0.00 & 0.00 & 0.00 & 0.00 & 0.00 & 0.00 & 0.00 \\
\hline 0.00 & 0.00 & 0.00 & 0.00 & 0.00 & 0.00 & 0.00 & 0.00 & 0.00 \\
\hline 0.00 & 0.00 & 0.00 & 0.00 & 0.00 & 0.00 & 0.00 & 0.00 & 0.00 \\
\hline 0.33 & 0.00 & 0.33 & 0.00 & 0.67 & 0.33 & 0.00 & 0.32 & 0.67 \\
\hline 2.00 & 2.32 & 2.67 & 0.33 & 4.66 & 1.66 & 1.66 & 2.59 & 1.67 \\
\hline 0.00 & 0.00 & 0.00 & 0.00 & 0.00 & 0.00 & 0.00 & 0.00 & 0.00 \\
\hline
\end{tabular}




$\begin{array}{rrrrrrrrr}40.93 & 25.21 & 19.33 & 21.26 & 33.28 & 37.60 & 30.90 & 27.18 & 29.00 \\ 3.33 & 5.64 & 7.67 & 1.66 & 4.33 & 0.67 & 0.66 & 1.29 & 3.33 \\ 0.67 & 0.00 & 0.67 & 0.00 & 0.33 & 0.00 & 0.00 & 0.00 & 0.33 \\ 0.00 & 0.33 & 0.00 & 0.33 & 0.33 & 0.00 & 0.00 & 0.00 & 0.00 \\ 9.98 & 6.97 & 12.83 & 5.15 & 5.66 & 5.99 & 9.80 & 12.30 & 7.67 \\ 0.00 & 0.00 & 0.00 & 0.00 & 0.00 & 0.00 & 0.00 & 0.00 & 0.00 \\ 0.00 & 0.00 & 1.00 & 0.00 & 0.00 & 0.33 & 0.00 & 0.00 & 0.67 \\ 0.33 & 0.66 & 0.33 & 0.66 & 0.67 & 0.33 & 1.99 & 0.65 & 0.67 \\ 0.00 & 1.00 & 0.33 & 0.33 & 1.00 & 0.00 & 0.00 & 0.00 & 0.00 \\ 0.00 & 0.00 & 0.33 & 1.33 & 0.00 & 0.00 & 1.00 & 6.47 & 0.00 \\ 0.33 & 0.00 & 0.00 & 0.66 & 0.00 & 0.00 & 0.66 & 0.00 & 0.67 \\ 3.33 & 3.65 & 3.00 & 3.65 & 3.00 & 3.99 & 3.32 & 0.97 & 2.67 \\ 0.00 & 0.33 & 0.00 & 0.17 & 0.00 & 0.67 & 0.00 & 0.00 & 0.00 \\ 0.00 & 0.33 & 0.67 & 0.00 & 0.00 & 1.00 & 0.00 & 0.32 & 0.00\end{array}$




\begin{tabular}{|c|c|c|c|c|c|c|c|c|}
\hline 19.28 & 19.48 & 19.68 & 19.87 & 20.03 & 20.07 & 20.22 & 20.27 & 20.47 \\
\hline 3494 & 3531 & 3568 & 3603 & 3632 & 3639 & 3667 & 3676 & 3713 \\
\hline 1.33 & 1.31 & 0.67 & 1.98 & 0.00 & 2.00 & 0.00 & 0.33 & 0.00 \\
\hline 1.00 & 0.16 & 0.00 & 0.00 & 0.33 & 0.00 & 0.17 & 0.00 & 0.67 \\
\hline 0.33 & 0.00 & 0.00 & 0.00 & 0.00 & 0.00 & 0.00 & 0.00 & 0.00 \\
\hline 0.00 & 0.00 & 0.00 & 0.00 & 0.00 & 0.00 & 0.33 & 0.00 & 0.00 \\
\hline 3.33 & 0.00 & 0.33 & 0.00 & 2.00 & 0.00 & 1.00 & 0.00 & 1.00 \\
\hline 0.00 & 0.00 & 0.00 & 0.00 & 0.00 & 0.00 & 0.00 & 0.00 & 0.00 \\
\hline 1.00 & 1.31 & 4.00 & 1.65 & 1.00 & 1.00 & 0.67 & 2.33 & 2.00 \\
\hline 0.33 & 0.00 & 0.00 & 0.33 & 0.33 & 0.17 & 0.00 & 0.17 & 1.33 \\
\hline 0.00 & 0.00 & 0.00 & 0.00 & 0.00 & 0.00 & 0.00 & 0.00 & 0.00 \\
\hline 0.83 & 0.82 & 0.33 & 0.49 & 0.67 & 0.83 & 0.17 & 1.00 & 1.33 \\
\hline 0.00 & 0.16 & 0.00 & 0.33 & 0.00 & 0.17 & 0.00 & 0.00 & 0.00 \\
\hline 0.67 & 0.00 & 0.00 & 0.00 & 0.00 & 0.00 & 0.67 & 0.00 & 0.00 \\
\hline 0.00 & 0.00 & 0.00 & 0.00 & 0.00 & 0.00 & 0.00 & 0.00 & 0.00 \\
\hline 0.00 & 0.65 & 1.00 & 0.99 & 1.33 & 0.33 & 0.00 & 0.66 & 1.00 \\
\hline 2.67 & 1.15 & 2.33 & 3.46 & 2.00 & 2.33 & 1.00 & 1.99 & 1.67 \\
\hline 0.00 & 0.00 & 0.00 & 0.00 & 0.00 & 0.00 & 1.00 & 0.00 & 0.00 \\
\hline 0.00 & 0.33 & 0.33 & 0.33 & 0.00 & 0.00 & 0.33 & 0.00 & 0.00 \\
\hline 1.83 & 1.31 & 1.50 & 3.13 & 4.16 & 1.83 & 2.66 & 2.99 & 2.83 \\
\hline 3.00 & 0.98 & 2.33 & 4.94 & 4.66 & 5.33 & 2.66 & 6.31 & 1.67 \\
\hline 0.00 & 0.16 & 0.00 & 1.15 & 0.17 & 0.50 & 0.00 & 0.50 & 0.50 \\
\hline 1.67 & 1.31 & 0.67 & 2.14 & 1.50 & 1.00 & 1.00 & 1.00 & 4.00 \\
\hline 0.00 & 0.00 & 0.00 & 0.00 & 1.00 & 0.67 & 0.00 & 0.00 & 0.33 \\
\hline 1.33 & 2.95 & 3.00 & 3.62 & 1.33 & 4.83 & 0.67 & 1.33 & 0.67 \\
\hline 1.00 & 0.00 & 0.17 & 0.16 & 0.33 & 0.67 & 0.33 & 0.00 & 0.17 \\
\hline 0.00 & 0.00 & 0.33 & 0.00 & 0.00 & 0.50 & 0.00 & 0.66 & 0.17 \\
\hline 0.83 & 0.16 & 0.50 & 0.16 & 1.83 & 0.33 & 0.67 & 0.66 & 0.50 \\
\hline 0.00 & 0.33 & 0.00 & 0.99 & 0.00 & 0.67 & 0.00 & 0.00 & 0.00 \\
\hline 0.67 & 0.65 & 1.00 & 0.16 & 1.16 & 0.33 & 1.83 & 0.33 & 1.33 \\
\hline 7.17 & 6.55 & 8.50 & 10.21 & 6.99 & 4.83 & 9.48 & 6.31 & 5.83 \\
\hline 1.67 & 1.64 & 5.33 & 3.29 & 3.99 & 2.67 & 1.00 & 1.00 & 4.00 \\
\hline 0.00 & 0.00 & 0.00 & 0.00 & 0.00 & 0.33 & 0.00 & 0.00 & 0.00 \\
\hline 0.50 & 2.29 & 1.17 & 0.82 & 1.00 & 1.00 & 1.00 & 0.00 & 1.33 \\
\hline 1.50 & 1.47 & 0.33 & 1.32 & 1.00 & 0.83 & 2.33 & 3.32 & 2.67 \\
\hline 2.50 & 0.98 & 0.67 & 2.64 & 1.16 & 1.83 & 1.16 & 1.33 & 0.67 \\
\hline 0.00 & 0.00 & 0.00 & 0.00 & 0.00 & 0.00 & 0.00 & 0.00 & 0.00 \\
\hline 0.00 & 0.00 & 0.00 & 0.00 & 0.00 & 0.00 & 0.00 & 0.00 & 0.00 \\
\hline 0.00 & 0.00 & 0.00 & 0.00 & 0.00 & 0.00 & 0.00 & 0.00 & 0.00 \\
\hline 0.00 & 0.00 & 0.00 & 0.00 & 0.00 & 0.00 & 0.00 & 0.00 & 0.00 \\
\hline 1.00 & 0.33 & 2.33 & 1.98 & 1.33 & 1.67 & 2.33 & 1.33 & 0.67 \\
\hline 0.00 & 0.00 & 0.00 & 0.00 & 0.00 & 0.00 & 0.00 & 0.00 & 0.00 \\
\hline 0.00 & 0.00 & 0.00 & 0.00 & 0.00 & 0.00 & 0.00 & 0.00 & 0.00 \\
\hline 0.00 & 0.00 & 0.00 & 0.00 & 0.00 & 0.00 & 0.00 & 0.00 & 0.00 \\
\hline 0.00 & 0.00 & 0.00 & 0.00 & 0.00 & 0.00 & 0.00 & 0.00 & 0.00 \\
\hline 0.00 & 0.00 & 0.00 & 0.00 & 0.00 & 0.00 & 0.00 & 0.00 & 0.00 \\
\hline 0.00 & 0.00 & 0.00 & 0.00 & 0.00 & 0.00 & 0.00 & 0.00 & 0.00 \\
\hline 0.00 & 0.65 & 0.33 & 0.99 & 1.33 & 0.67 & 0.00 & 0.00 & 0.00 \\
\hline 2.67 & 0.98 & 2.67 & 1.98 & 2.00 & 9.33 & 1.33 & 2.99 & 1.33 \\
\hline 0.00 & 0.00 & 0.00 & 0.00 & 0.00 & 0.00 & 0.00 & 0.00 & 0.67 \\
\hline
\end{tabular}




$\begin{array}{rrrrrrrrr}36.00 & 31.42 & 32.00 & 25.37 & 30.28 & 20.33 & 39.93 & 27.57 & 33.00 \\ 0.33 & 19.64 & 4.00 & 1.98 & 2.00 & 1.67 & 1.33 & 8.97 & 0.00 \\ 0.33 & 0.00 & 0.00 & 0.00 & 0.00 & 0.33 & 0.33 & 0.33 & 0.33 \\ 0.00 & 0.33 & 0.33 & 0.00 & 0.00 & 0.00 & 0.00 & 0.00 & 0.33 \\ 7.83 & 5.89 & 16.17 & 9.23 & 5.66 & 14.33 & 6.99 & 13.12 & 8.17 \\ 0.00 & 0.00 & 0.00 & 0.00 & 0.33 & 0.00 & 0.00 & 0.33 & 0.00 \\ 0.33 & 0.00 & 0.00 & 0.66 & 1.00 & 0.33 & 0.00 & 0.00 & 0.00 \\ 0.00 & 1.31 & 0.33 & 0.66 & 1.33 & 0.33 & 0.00 & 0.66 & 0.67 \\ 0.00 & 0.00 & 0.00 & 0.00 & 0.67 & 0.00 & 0.00 & 0.00 & 0.00 \\ 0.33 & 0.00 & 0.33 & 0.00 & 0.33 & 0.00 & 0.67 & 2.33 & 3.00 \\ 0.33 & 0.00 & 0.00 & 0.33 & 0.33 & 0.00 & 1.33 & 0.00 & 0.33 \\ 2.67 & 2.95 & 1.33 & 2.64 & 2.33 & 2.00 & 3.99 & 0.66 & 2.00 \\ 0.00 & 0.00 & 0.00 & 0.00 & 0.00 & 0.00 & 0.00 & 0.00 & 0.00 \\ 0.33 & 0.00 & 0.00 & 0.00 & 0.67 & 0.00 & 0.67 & 0.00 & 0.00\end{array}$




\begin{tabular}{|c|c|c|c|c|c|c|c|c|}
\hline 20.67 & 20.87 & 21.07 & 21.27 & 21.46 & 21.5 & 21.66 & 21.67 & 21.7 \\
\hline 3750 & 3786 & 3823 & 3856 & 3884 & 3890 & 3914 & 3916 & 3920 \\
\hline 0.33 & 4.60 & 0.33 & 0.33 & 0.00 & 0.00 & 0.00 & 0.00 & 0.33 \\
\hline 0.00 & 0.16 & 0.17 & 0.66 & 0.00 & 0.33 & 0.00 & 0.00 & 0.00 \\
\hline 0.00 & 0.00 & 0.00 & 0.00 & 0.00 & 0.00 & 0.00 & 0.00 & 0.00 \\
\hline 0.33 & 0.00 & 0.00 & 0.00 & 0.00 & 0.00 & 0.00 & 0.00 & 0.33 \\
\hline 0.00 & 0.00 & 0.00 & 0.00 & 0.00 & 0.33 & 1.32 & 0.32 & 0.00 \\
\hline 0.00 & 0.00 & 0.00 & 0.00 & 0.00 & 0.00 & 0.00 & 0.00 & 0.00 \\
\hline 0.00 & 2.30 & 1.00 & 0.99 & 0.33 & 1.67 & 0.99 & 0.00 & 1.33 \\
\hline 0.00 & 0.33 & 0.00 & 0.00 & 0.00 & 0.00 & 0.00 & 0.00 & 0.00 \\
\hline 0.00 & 0.00 & 0.00 & 0.00 & 0.00 & 0.00 & 0.00 & 0.00 & 0.00 \\
\hline 0.83 & 0.00 & 0.50 & 0.50 & 1.33 & 0.17 & 1.32 & 0.81 & 0.66 \\
\hline 0.00 & 0.00 & 0.00 & 0.00 & 0.00 & 0.33 & 0.17 & 0.00 & 0.00 \\
\hline 0.00 & 0.00 & 0.00 & 0.00 & 0.00 & 0.00 & 0.00 & 0.00 & 0.00 \\
\hline 0.00 & 0.00 & 0.33 & 0.17 & 0.00 & 0.00 & 0.00 & 0.00 & 0.00 \\
\hline 1.00 & 0.99 & 0.00 & 0.99 & 0.33 & 0.00 & 0.00 & 0.00 & 0.00 \\
\hline 0.33 & 1.81 & 1.00 & 0.66 & 1.00 & 0.83 & 2.48 & 0.00 & 0.33 \\
\hline 0.00 & 0.00 & 0.00 & 0.00 & 0.00 & 0.00 & 0.00 & 0.00 & 0.00 \\
\hline 0.33 & 0.00 & 0.00 & 0.00 & 0.67 & 0.33 & 0.33 & 0.32 & 0.00 \\
\hline 1.16 & 1.64 & 1.16 & 0.99 & 3.33 & 1.00 & 3.48 & 1.13 & 2.33 \\
\hline 4.64 & 2.96 & 3.32 & 2.98 & 5.66 & 1.67 & 2.98 & 2.58 & 3.99 \\
\hline 0.50 & 0.00 & 0.33 & 0.00 & 0.00 & 0.00 & 0.17 & 0.16 & 1.00 \\
\hline 2.82 & 1.97 & 1.33 & 1.99 & 1.33 & 2.33 & 1.99 & 1.61 & 1.33 \\
\hline 0.33 & 0.00 & 0.00 & 0.00 & 0.00 & 0.17 & 0.00 & 0.00 & 0.33 \\
\hline 2.32 & 3.28 & 4.98 & 6.29 & 0.33 & 2.00 & 0.00 & 0.64 & 2.99 \\
\hline 0.00 & 0.00 & 0.50 & 0.00 & 0.00 & 0.00 & 0.00 & 0.00 & 0.00 \\
\hline 0.00 & 0.49 & 0.33 & 0.33 & 0.33 & 0.50 & 0.00 & 0.00 & 0.17 \\
\hline 0.66 & 0.16 & 0.00 & 2.15 & 1.00 & 0.17 & 0.00 & 0.00 & 1.33 \\
\hline 0.00 & 0.00 & 0.66 & 0.00 & 1.00 & 0.00 & 0.00 & 0.32 & 0.00 \\
\hline 0.83 & 1.31 & 0.50 & 0.83 & 2.00 & 0.50 & 0.99 & 0.81 & 1.00 \\
\hline 5.97 & 8.70 & 4.81 & 7.78 & 7.49 & 9.33 & 4.30 & 6.76 & 5.48 \\
\hline 2.99 & 2.30 & 0.33 & 2.98 & 2.00 & 2.67 & 3.31 & 0.97 & 2.99 \\
\hline 0.33 & 0.00 & 0.00 & 0.00 & 0.00 & 0.00 & 0.00 & 0.32 & 0.00 \\
\hline 0.66 & 0.82 & 1.82 & 1.16 & 1.00 & 0.17 & 0.17 & 0.00 & 0.17 \\
\hline 0.66 & 1.31 & 1.00 & 1.99 & 0.50 & 2.67 & 1.32 & 0.64 & 0.66 \\
\hline 2.16 & 1.48 & 0.00 & 1.32 & 0.50 & 1.00 & 0.17 & 0.48 & 1.00 \\
\hline 0.00 & 0.00 & 0.00 & 0.00 & 0.00 & 0.00 & 0.00 & 0.00 & 0.00 \\
\hline 0.00 & 0.00 & 0.00 & 0.00 & 0.00 & 0.00 & 0.00 & 0.00 & 0.00 \\
\hline 0.00 & 0.00 & 0.00 & 0.00 & 0.00 & 0.00 & 0.00 & 0.00 & 0.00 \\
\hline 0.00 & 0.00 & 0.00 & 0.00 & 0.00 & 0.00 & 0.00 & 0.00 & 0.00 \\
\hline 1.99 & 0.99 & 0.66 & 0.33 & 0.67 & 0.33 & 2.65 & 2.58 & 4.32 \\
\hline 0.00 & 0.00 & 0.00 & 0.00 & 0.00 & 0.00 & 0.00 & 0.00 & 0.00 \\
\hline 0.00 & 0.00 & 0.00 & 0.00 & 0.00 & 0.00 & 0.00 & 0.00 & 0.00 \\
\hline 0.00 & 0.00 & 0.00 & 0.00 & 0.00 & 0.00 & 0.00 & 0.00 & 0.00 \\
\hline 0.00 & 0.00 & 0.00 & 0.00 & 0.00 & 0.00 & 0.00 & 0.00 & 0.00 \\
\hline 0.00 & 0.00 & 0.00 & 0.33 & 0.00 & 0.00 & 0.00 & 0.00 & 0.33 \\
\hline 0.00 & 0.00 & 0.00 & 0.33 & 0.00 & 0.00 & 0.00 & 0.00 & 0.00 \\
\hline 0.33 & 0.33 & 0.66 & 0.33 & 0.33 & 0.33 & 0.33 & 0.00 & 0.6 \\
\hline 1.66 & 0.99 & 5.64 & 0.66 & 1.33 & 0.33 & 3.97 & 3.22 & 1.33 \\
\hline 0.00 & 0.00 & 0.00 & 0.00 & 0.00 & 0.00 & 0.00 & 0.00 & \\
\hline
\end{tabular}




$\begin{array}{rrrrrrrrr}43.78 & 38.75 & 17.25 & 37.42 & 45.59 & 52.33 & 50.99 & 58.94 & 41.20 \\ 1.00 & 2.63 & 34.83 & 2.98 & 1.00 & 0.67 & 0.00 & 1.93 & 0.33 \\ 0.00 & 0.00 & 0.33 & 0.00 & 0.00 & 0.00 & 0.33 & 0.00 & 0.00 \\ 0.00 & 0.00 & 0.00 & 0.00 & 0.00 & 0.00 & 0.00 & 0.00 & 0.33 \\ 5.97 & 4.43 & 3.65 & 5.13 & 5.16 & 4.50 & 5.30 & 5.64 & 7.97 \\ 0.66 & 0.00 & 0.00 & 0.00 & 0.67 & 0.00 & 0.00 & 0.00 & 0.00 \\ 0.00 & 0.00 & 0.00 & 0.33 & 0.00 & 0.00 & 0.33 & 0.00 & 0.00 \\ 1.99 & 0.33 & 0.33 & 0.00 & 0.67 & 0.33 & 0.00 & 0.00 & 0.00 \\ 0.66 & 0.00 & 0.00 & 0.00 & 0.33 & 0.00 & 0.00 & 0.00 & 0.66 \\ 0.66 & 0.99 & 0.66 & 0.00 & 0.00 & 0.33 & 0.00 & 0.00 & 1.33 \\ 0.00 & 0.00 & 0.00 & 0.00 & 0.00 & 0.00 & 0.00 & 0.00 & 0.00 \\ 1.00 & 1.31 & 1.33 & 1.66 & 4.33 & 1.00 & 2.32 & 2.25 & 1.99 \\ 0.66 & 0.00 & 0.00 & 0.00 & 0.67 & 1.33 & 0.00 & 0.00 & 0.00 \\ 0.66 & 0.33 & 0.33 & 0.00 & 0.33 & 0.33 & 0.00 & 0.00 & 1.00\end{array}$




\begin{tabular}{|c|c|c|c|c|c|c|c|c|}
\hline 21.86 & 21.93 & 22.06 & 22.14 & 22.18 & 22.25 & 22.28 & 22.47 & $\begin{array}{r}22.505 \\
4042\end{array}$ \\
\hline 3944 & 3955 & 3974 & 3986 & 3992 & 4003 & 4007 & 4036 & 4042 \\
\hline 0.00 & 0.33 & 0.34 & 0.00 & 0.00 & 0.00 & 0.98 & 0.33 & 0.00 \\
\hline 0.33 & 0.33 & 1.34 & 0.00 & 0.00 & 0.33 & 0.00 & 0.00 & 0.33 \\
\hline 0.00 & 0.33 & 0.00 & 0.00 & 0.00 & 0.00 & 0.00 & 0.33 & 0.00 \\
\hline 0.00 & 0.83 & 0.00 & 0.00 & 0.33 & 0.33 & 0.33 & 0.00 & 0.33 \\
\hline 0.33 & 0.33 & 0.00 & 0.00 & 0.33 & 0.66 & 0.00 & 0.99 & 0.00 \\
\hline 0.00 & 0.00 & 0.00 & 0.00 & 0.00 & 0.00 & 0.00 & 0.00 & 0.00 \\
\hline 1.33 & 0.00 & 1.01 & 0.00 & 0.67 & 8.31 & 0.65 & 0.66 & 0.00 \\
\hline 0.66 & 0.00 & 0.34 & 1.00 & 0.00 & 0.00 & 0.00 & 0.00 & 0.33 \\
\hline 0.00 & 0.00 & 0.00 & 0.00 & 0.00 & 0.00 & 0.00 & 0.00 & 0.00 \\
\hline 0.17 & 0.50 & 2.18 & 1.33 & 0.83 & 0.83 & 0.16 & 0.33 & 0.50 \\
\hline 0.00 & 0.00 & 0.00 & 0.00 & 0.00 & 0.00 & 0.00 & 0.00 & 0.00 \\
\hline 0.00 & 0.00 & 0.00 & 0.00 & 0.00 & 0.00 & 0.00 & 0.00 & 0.00 \\
\hline 0.00 & 0.00 & 0.00 & 0.00 & 0.17 & 0.00 & 0.00 & 0.00 & 0.00 \\
\hline 0.66 & 0.00 & 0.00 & 0.00 & 0.33 & 0.00 & 0.82 & 0.33 & 6.66 \\
\hline 2.82 & 0.67 & 0.50 & 0.00 & 0.83 & 1.16 & 0.98 & 0.66 & 1.00 \\
\hline 0.00 & 1.33 & 0.00 & 0.00 & 0.00 & 0.00 & 0.00 & 0.00 & 0.00 \\
\hline 0.00 & 0.00 & 0.00 & 0.00 & 0.00 & 0.00 & 0.00 & 0.00 & 0.00 \\
\hline 2.49 & 1.16 & 2.51 & 2.00 & 1.83 & 1.00 & 2.12 & 1.64 & 0.50 \\
\hline 4.32 & 1.66 & 3.02 & 0.00 & 3.00 & 1.33 & 3.59 & 3.62 & 4.33 \\
\hline 1.00 & 0.00 & 1.01 & 0.33 & 0.17 & 0.66 & 0.00 & 0.33 & 0.67 \\
\hline 1.66 & 1.66 & 1.34 & 0.67 & 1.50 & 1.33 & 1.63 & 2.63 & 1.00 \\
\hline 0.00 & 0.00 & 0.00 & 0.00 & 0.33 & 0.00 & 0.00 & 0.66 & 0.00 \\
\hline 1.99 & 0.67 & 1.01 & 1.33 & 1.00 & 0.00 & 1.63 & 3.29 & 0.67 \\
\hline 0.00 & 0.00 & 0.00 & 0.00 & 0.00 & 0.00 & 0.00 & 0.00 & 0.00 \\
\hline 0.00 & 0.67 & 0.34 & 0.00 & 0.00 & 0.00 & 0.16 & 0.00 & 0.00 \\
\hline 0.00 & 1.00 & 0.00 & 0.83 & 1.00 & 0.33 & 0.98 & 1.15 & 0.67 \\
\hline 0.00 & 0.00 & 0.00 & 0.67 & 0.00 & 1.50 & 0.82 & 0.00 & 0.00 \\
\hline 0.33 & 0.83 & 0.50 & 0.00 & 0.33 & 0.83 & 0.65 & 0.82 & 0.33 \\
\hline 10.13 & 8.32 & 9.05 & 6.32 & 11.65 & 5.32 & 6.36 & 8.72 & 5.49 \\
\hline 1.33 & 3.33 & 0.34 & 2.00 & 1.66 & 1.99 & 1.96 & 1.97 & 3.00 \\
\hline 0.00 & 0.00 & 0.00 & 0.00 & 0.00 & 0.00 & 0.16 & 0.00 & 0.00 \\
\hline 0.00 & 0.83 & 0.00 & 0.33 & 1.33 & 0.33 & 1.14 & 2.47 & 0.33 \\
\hline 0.00 & 0.33 & 1.34 & 0.00 & 1.83 & 0.00 & 0.33 & 0.66 & 0.67 \\
\hline 1.33 & 0.67 & 0.50 & 0.67 & 0.83 & 2.99 & 0.98 & 0.82 & 0.00 \\
\hline 0.00 & 0.00 & 0.00 & 0.00 & 0.00 & 0.00 & 0.00 & 0.00 & 0.0 \\
\hline 0.00 & 0.00 & 0.00 & 0.00 & 0.00 & 0.00 & 0.00 & 0.00 & 0.00 \\
\hline 0.00 & 0.00 & 0.00 & 0.00 & 0.00 & 0.00 & 0.00 & 0.00 & 0.00 \\
\hline 0.00 & 0.00 & 0.00 & 0.00 & 0.00 & 0.00 & 0.00 & 0.00 & 0.00 \\
\hline 0.66 & 0.33 & 1.34 & 1.00 & 0.00 & 0.33 & 1.31 & 0.33 & 0.33 \\
\hline 0.00 & 0.00 & 0.00 & 0.00 & 0.00 & 0.00 & 0.00 & 0.00 & 0.00 \\
\hline 0.00 & 0.00 & 0.00 & 0.00 & 0.00 & 0.00 & 0.00 & 0.00 & 0.00 \\
\hline 0.00 & 0.00 & 0.00 & 0.00 & 0.00 & 0.00 & 0.00 & 0.00 & 0.0 \\
\hline 0.00 & 0.00 & 0.00 & 0.00 & 0.00 & 0.00 & 0.00 & 0.00 & 0.00 \\
\hline 0.00 & 0.00 & 0.00 & 0.00 & 0.00 & 0.33 & 0.00 & 0.00 & 0.00 \\
\hline 0.00 & 0.00 & 0.34 & 0.00 & 0.00 & 0.00 & 0.00 & 0.00 & 0.00 \\
\hline 0.66 & 0.33 & 0.67 & 0.33 & 0.00 & 0.00 & 0.00 & 0.00 & 0.00 \\
\hline 2.33 & 3.66 & 2.35 & 1.66 & 1.33 & 1.66 & 3.26 & 1.32 & 1.66 \\
\hline 0.00 & 0.00 & 0.00 & 0.00 & 0.00 & 0.00 & 0.00 & 0.00 & 0.0 \\
\hline
\end{tabular}




$\begin{array}{rrrrrrrrr}43.52 & 39.93 & 44.89 & 48.92 & 52.58 & 49.17 & 41.44 & 32.89 & 57.90 \\ 1.00 & 0.00 & 1.34 & 3.00 & 1.00 & 1.33 & 0.33 & 16.45 & 0.00 \\ 0.00 & 0.33 & 0.34 & 0.33 & 0.33 & 0.00 & 0.33 & 0.00 & 0.00 \\ 0.00 & 0.33 & 0.67 & 0.33 & 0.00 & 0.33 & 0.33 & 0.00 & 0.00 \\ 8.64 & 17.64 & 7.71 & 10.15 & 3.00 & 4.65 & 15.17 & 5.26 & 4.99 \\ 0.00 & 0.00 & 0.00 & 0.00 & 0.33 & 0.00 & 0.00 & 0.00 & 0.00 \\ 0.00 & 0.00 & 0.34 & 1.66 & 0.00 & 0.00 & 0.00 & 0.33 & 0.00 \\ 0.33 & 0.67 & 0.34 & 1.33 & 0.67 & 1.33 & 1.31 & 0.33 & 1.33 \\ 0.33 & 0.33 & 0.00 & 0.67 & 0.00 & 0.33 & 0.00 & 0.00 & 0.00 \\ 0.66 & 0.00 & 0.00 & 0.00 & 0.00 & 0.66 & 0.00 & 0.00 & 0.00 \\ 0.33 & 0.00 & 0.34 & 0.00 & 0.00 & 0.33 & 0.00 & 0.33 & 0.33 \\ 1.33 & 3.00 & 0.67 & 2.00 & 1.33 & 3.32 & 2.28 & 1.97 & 0.67 \\ 0.00 & 0.00 & 0.67 & 0.00 & 0.00 & 0.00 & 0.00 & 0.00 & 0.00 \\ 0.00 & 0.00 & 0.34 & 0.33 & 0.33 & 0.33 & 0.00 & 0.66 & 0.00\end{array}$




\begin{tabular}{|c|c|c|c|c|c|c|c|c|}
\hline 22.59 & 22.65 & 22.7 & 22.705 & 22.77 & 22.81 & 22.86 & 23 & 23.06 \\
\hline 4054 & 4063 & 4070 & 4072 & 4081 & 4087 & 4094 & 4115 & 4124 \\
\hline 0.00 & 0.00 & 0.67 & 0.00 & 0.00 & 1.00 & 0.00 & 0.67 & 0.00 \\
\hline 0.33 & 0.33 & 0.33 & 0.82 & 0.00 & 0.00 & 0.00 & 0.00 & 0.00 \\
\hline 0.00 & 0.00 & 0.33 & 0.00 & 0.00 & 0.00 & 0.00 & 0.00 & 0.00 \\
\hline 0.00 & 0.00 & 0.00 & 0.33 & 0.00 & 0.00 & 0.33 & 0.00 & 0.00 \\
\hline 0.00 & 0.00 & 0.33 & 0.66 & 1.31 & 0.67 & 1.99 & 0.00 & 0.00 \\
\hline 0.00 & 0.00 & 0.00 & 0.00 & 0.00 & 0.00 & 0.00 & 0.00 & 0.00 \\
\hline 0.00 & 0.66 & 0.67 & 0.33 & 0.66 & 0.67 & 0.00 & 0.00 & 0.00 \\
\hline 0.00 & 0.00 & 0.50 & 0.33 & 0.33 & 0.50 & 0.00 & 0.17 & 0.00 \\
\hline 0.00 & 0.00 & 0.00 & 0.00 & 0.00 & 0.00 & 0.00 & 0.00 & 0.00 \\
\hline 1.66 & 1.16 & 1.17 & 0.66 & 1.15 & 2.16 & 1.99 & 0.67 & 0.65 \\
\hline 0.00 & 0.00 & 0.00 & 0.00 & 0.00 & 0.00 & 0.00 & 0.00 & 0.16 \\
\hline 0.00 & 0.00 & 0.00 & 0.00 & 0.00 & 0.00 & 0.00 & 0.00 & 0.00 \\
\hline 0.00 & 0.00 & 0.00 & 0.00 & 0.00 & 0.00 & 0.00 & 0.33 & 0.00 \\
\hline 0.00 & 0.66 & 1.00 & 0.66 & 0.00 & 0.33 & 0.33 & 0.33 & 0.65 \\
\hline 1.00 & 1.32 & 3.67 & 0.33 & 1.64 & 0.67 & 0.33 & 1.00 & 1.31 \\
\hline 0.00 & 0.00 & 0.00 & 0.00 & 0.00 & 0.00 & 0.00 & 0.00 & 0.00 \\
\hline 0.00 & 0.00 & 0.00 & 0.00 & 0.66 & 0.00 & 0.00 & 0.00 & 0.00 \\
\hline 1.66 & 0.99 & 1.33 & 1.97 & 2.13 & 3.00 & 1.99 & 1.83 & 1.47 \\
\hline 0.66 & 3.97 & 6.00 & 2.63 & 1.97 & 2.00 & 5.30 & 0.67 & 0.00 \\
\hline 0.50 & 0.33 & 0.83 & 0.66 & 0.33 & 0.00 & 0.00 & 0.33 & 1.31 \\
\hline 1.33 & 1.98 & 1.67 & 0.16 & 2.96 & 2.00 & 2.98 & 3.00 & 1.64 \\
\hline 0.00 & 0.00 & 0.67 & 0.00 & 0.00 & 0.33 & 0.00 & 0.00 & 0.33 \\
\hline 0.66 & 0.33 & 3.33 & 2.96 & 0.33 & 3.00 & 0.66 & 0.33 & 1.31 \\
\hline 0.00 & 0.00 & 0.00 & 0.00 & 0.00 & 0.17 & 0.00 & 0.00 & 0.00 \\
\hline 0.00 & 0.00 & 0.00 & 0.16 & 0.66 & 0.17 & 0.33 & 0.17 & 0.33 \\
\hline 0.33 & 1.65 & 0.17 & 0.66 & 1.81 & 0.67 & 0.00 & 1.00 & 1.31 \\
\hline 0.00 & 0.33 & 2.67 & 0.00 & 0.33 & 0.00 & 0.00 & 0.33 & 0.00 \\
\hline 0.50 & 2.48 & 0.00 & 1.97 & 2.13 & 0.17 & 0.00 & 0.83 & 2.29 \\
\hline 11.77 & 9.09 & 6.67 & 9.38 & 11.66 & 7.82 & 7.45 & 8.00 & 8.18 \\
\hline 2.32 & 2.64 & 2.67 & 2.30 & 1.64 & 2.00 & 1.99 & 2.33 & 2.62 \\
\hline 0.00 & 0.00 & 0.33 & 0.00 & 0.00 & 0.00 & 0.00 & 0.00 & 0.00 \\
\hline 0.33 & 0.00 & 0.50 & 1.81 & 0.99 & 0.67 & 1.32 & 0.50 & 0.65 \\
\hline 0.66 & 0.00 & 1.33 & 1.81 & 0.00 & 0.00 & 0.66 & 2.33 & 0.65 \\
\hline 0.50 & 0.00 & 0.33 & 0.66 & 1.48 & 1.16 & 1.66 & 1.67 & 1.64 \\
\hline 0.00 & 0.00 & 0.00 & 0.00 & 0.00 & 0.00 & 0.00 & 0.00 & 0.00 \\
\hline 0.33 & 0.00 & 0.00 & 0.00 & 0.00 & 0.00 & 0.00 & 0.00 & 0.00 \\
\hline 0.00 & 0.00 & 0.00 & 0.00 & 0.00 & 0.00 & 0.00 & 0.00 & 0.00 \\
\hline 0.00 & 0.00 & 0.00 & 0.33 & 0.00 & 0.00 & 0.00 & 0.00 & 0.00 \\
\hline 0.00 & 0.00 & 0.33 & 0.99 & 0.00 & 1.00 & 0.66 & 1.33 & 0.98 \\
\hline 0.00 & 0.00 & 0.00 & 0.00 & 0.00 & 0.00 & 0.00 & 0.00 & 0.00 \\
\hline 0.00 & 0.00 & 0.00 & 0.00 & 0.00 & 0.00 & 0.00 & 0.00 & 0.00 \\
\hline 0.00 & 0.00 & 0.00 & 0.00 & 0.00 & 0.00 & 0.00 & 0.00 & 0.00 \\
\hline 0.00 & 0.00 & 0.00 & 0.00 & 0.00 & 0.00 & 0.00 & 0.00 & 0.00 \\
\hline 0.00 & 0.33 & 0.00 & 0.00 & 0.00 & 0.00 & 0.00 & 0.00 & 0.00 \\
\hline 0.00 & 0.00 & 0.00 & 0.00 & 0.00 & 0.00 & 0.00 & 0.00 & 0.00 \\
\hline 0.00 & 0.33 & 0.00 & 0.33 & 0.33 & 0.33 & 0.66 & 0.33 & 0.33 \\
\hline 1.33 & 0.99 & 1.33 & 1.64 & 0.99 & 4.66 & 1.32 & 3.00 & 1.96 \\
\hline 0.00 & 0.00 & 0.00 & 0.00 & 0.00 & 0.00 & 0.00 & 0.00 & 0.00 \\
\hline
\end{tabular}




$\begin{array}{rrrrrrrrr}64.68 & 58.84 & 35.00 & 47.04 & 54.19 & 35.94 & 47.02 & 46.67 & 51.06 \\ 0.66 & 0.00 & 17.33 & 0.00 & 0.00 & 1.66 & 0.33 & 2.67 & 1.31 \\ 0.00 & 0.00 & 0.00 & 0.00 & 0.00 & 0.00 & 0.00 & 0.00 & 0.33 \\ 0.00 & 0.33 & 0.00 & 0.00 & 0.00 & 0.00 & 0.00 & 0.33 & 0.33 \\ 2.32 & 3.14 & 2.33 & 5.43 & 2.96 & 12.65 & 5.13 & 8.67 & 5.40 \\ 0.33 & 0.00 & 0.00 & 0.00 & 0.33 & 0.00 & 0.00 & 0.33 & 0.00 \\ 0.00 & 0.00 & 0.00 & 0.00 & 0.00 & 0.00 & 0.00 & 0.33 & 0.00 \\ 0.00 & 0.99 & 0.33 & 0.66 & 0.66 & 1.00 & 0.33 & 0.67 & 0.65 \\ 0.00 & 0.00 & 0.00 & 0.00 & 0.00 & 0.00 & 0.00 & 0.00 & 0.33 \\ 0.00 & 0.33 & 0.00 & 0.00 & 0.33 & 0.00 & 0.00 & 0.00 & 0.00 \\ 0.00 & 0.00 & 0.00 & 0.00 & 0.00 & 0.00 & 0.00 & 0.00 & 0.00 \\ 1.99 & 1.65 & 0.33 & 2.63 & 0.33 & 1.66 & 2.98 & 2.33 & 2.95 \\ 0.00 & 0.00 & 0.00 & 0.00 & 0.00 & 0.00 & 0.00 & 0.00 & 0.00 \\ 0.00 & 0.00 & 0.00 & 0.33 & 0.00 & 0.00 & 0.00 & 0.33 & 0.98\end{array}$




\begin{tabular}{|c|c|c|c|c|c|c|c|c|}
\hline 23.2 & 23.35 & 23.43 & 23.69 & 25.99 & 26.19 & 26.38 & 26.59 & 26.79 \\
\hline 4145 & 4168 & 4180 & 4220 & 4574 & 4605 & 4634 & 4667 & 4726 \\
\hline 0.00 & 0.00 & 0.00 & 0.00 & 0.00 & 0.00 & 0.00 & 0.00 & 0.00 \\
\hline 0.00 & 0.00 & 0.00 & 0.33 & 0.00 & 0.00 & 0.00 & 0.33 & 0.00 \\
\hline 0.00 & 1.00 & 0.33 & 0.33 & 0.00 & 0.00 & 0.00 & 0.00 & 0.00 \\
\hline 0.00 & 0.00 & 0.00 & 0.00 & 0.00 & 0.00 & 0.66 & 0.67 & 0.00 \\
\hline 0.00 & 0.66 & 0.00 & 0.33 & 0.00 & 0.00 & 0.00 & 0.00 & 0.00 \\
\hline 0.00 & 0.00 & 0.00 & 0.00 & 0.00 & 0.00 & 0.00 & 0.00 & 0.00 \\
\hline 0.65 & 0.00 & 0.00 & 2.33 & 0.33 & 0.66 & 2.63 & 0.67 & 0.00 \\
\hline 0.00 & 0.00 & 0.00 & 0.00 & 0.33 & 0.00 & 0.33 & 0.00 & 0.33 \\
\hline 0.00 & 0.00 & 0.00 & 0.00 & 0.00 & 0.00 & 0.00 & 0.00 & 0.00 \\
\hline 0.97 & 1.00 & 0.16 & 0.67 & 0.99 & 1.98 & 0.82 & 1.00 & 0.83 \\
\hline 0.00 & 0.17 & 0.00 & 0.17 & 0.00 & 0.00 & 0.00 & 0.00 & 0.00 \\
\hline 0.00 & 0.66 & 0.00 & 0.00 & 0.00 & 0.00 & 0.00 & 0.00 & 0.00 \\
\hline 0.00 & 0.00 & 0.00 & 0.00 & 0.00 & 0.00 & 0.00 & 0.00 & 0.00 \\
\hline 0.00 & 0.00 & 0.00 & 0.00 & 0.00 & 0.33 & 0.00 & 0.17 & 0.00 \\
\hline 0.65 & 0.66 & 1.32 & 2.00 & 0.00 & 0.99 & 0.99 & 0.33 & 1.98 \\
\hline 0.00 & 0.00 & 0.00 & 0.33 & 0.00 & 0.00 & 0.00 & 0.00 & 0.00 \\
\hline 0.00 & 0.00 & 0.00 & 0.33 & 0.00 & 0.33 & 0.00 & 0.33 & 0.00 \\
\hline 0.48 & 1.00 & 2.31 & 1.83 & 1.82 & 1.65 & 2.79 & 1.67 & 1.82 \\
\hline 2.90 & 2.99 & 2.64 & 1.33 & 3.96 & 2.64 & 3.61 & 0.67 & 2.9 \\
\hline 0.00 & 0.00 & 0.00 & 0.00 & 0.17 & 0.00 & 0.16 & 1.00 & 0.17 \\
\hline 1.94 & 0.00 & 2.64 & 1.83 & 0.99 & 1.49 & 2.96 & 7.17 & 0.66 \\
\hline 0.00 & 0.00 & 0.00 & 0.00 & 0.00 & 0.00 & 0.33 & 0.00 & 0.00 \\
\hline 0.32 & 0.00 & 2.31 & 1.00 & 3.30 & 0.00 & 1.97 & 0.67 & 0.00 \\
\hline 0.00 & 0.00 & 0.00 & 0.00 & 0.00 & 0.33 & 0.00 & 0.00 & 0.00 \\
\hline 0.00 & 0.33 & 0.16 & 0.00 & 0.00 & 0.00 & 0.00 & 0.33 & 0.00 \\
\hline 1.13 & 0.66 & 0.49 & 0.33 & 0.33 & 0.33 & 0.66 & 0.00 & 0.33 \\
\hline 0.00 & 0.00 & 0.00 & 0.00 & 1.32 & 0.66 & 0.16 & 0.33 & 0.33 \\
\hline 1.29 & 1.50 & 0.49 & 1.50 & 0.33 & 0.66 & 0.99 & 0.83 & 0.66 \\
\hline 6.13 & 6.15 & 11.86 & 7.50 & 7.43 & 9.57 & 8.54 & 4.17 & 7.10 \\
\hline 0.65 & 2.33 & 1.98 & 1.00 & 1.98 & 3.96 & 2.96 & 2.33 & 2.97 \\
\hline 0.00 & 0.00 & 0.00 & 0.00 & 0.00 & 0.00 & 0.00 & 0.00 & 0.00 \\
\hline 0.32 & 1.16 & 0.66 & 0.00 & 0.99 & 0.33 & 1.64 & 0.33 & 0.00 \\
\hline 0.32 & 0.66 & 0.16 & 0.67 & 2.64 & 2.31 & 1.81 & 0.33 & 0.33 \\
\hline 1.13 & 0.50 & 1.65 & 0.33 & 2.15 & 0.83 & 1.15 & 0.67 & 1.65 \\
\hline 0.00 & 0.00 & 0.00 & 0.00 & 0.00 & 0.00 & 0.00 & 0.00 & 0.0 \\
\hline 0.00 & 0.00 & 0.00 & 0.00 & 0.00 & 0.00 & 0.00 & 0.00 & 0.00 \\
\hline 0.00 & 0.00 & 0.00 & 0.33 & 0.00 & 0.00 & 0.00 & 0.00 & 0.00 \\
\hline 0.32 & 0.00 & 0.00 & 0.00 & 0.00 & 0.00 & 0.00 & 0.00 & 0.00 \\
\hline 0.65 & 1.66 & 2.31 & 2.67 & 0.33 & 0.00 & 2.63 & 0.67 & 0.33 \\
\hline 0.00 & 0.00 & 0.00 & 0.00 & 0.00 & 0.00 & 0.00 & 0.00 & 0.00 \\
\hline 0.00 & 0.33 & 0.00 & 0.00 & 0.00 & 0.00 & 0.00 & 0.00 & 0.66 \\
\hline 0.00 & 0.00 & 0.00 & 0.00 & 0.00 & 0.00 & 0.00 & 0.00 & 0.0 \\
\hline 0.00 & 0.00 & 0.00 & 0.00 & 0.00 & 0.00 & 0.00 & 0.00 & 0.00 \\
\hline 0.00 & 0.00 & 0.00 & 0.00 & 0.00 & 0.00 & 0.00 & 0.00 & 0.0 \\
\hline 0.00 & 0.00 & 0.00 & 0.00 & 0.00 & 0.00 & 0.00 & 0.00 & 0.33 \\
\hline 0.00 & 0.00 & 0.00 & 0.00 & 0.66 & 0.00 & 0.00 & 0.00 & 0.00 \\
\hline 0.97 & 1.00 & 1.98 & 1.33 & 0.00 & 1.32 & 2.30 & 2.00 & 1.98 \\
\hline 0.00 & 0.00 & 0.00 & 0.00 & 0.00 & 0.00 & 0.00 & 0.00 & 0.0 \\
\hline
\end{tabular}




$\begin{array}{rrrrrrrrr}67.74 & 56.48 & 51.40 & 45.00 & 45.21 & 44.88 & 28.90 & 52.00 & 61.72 \\ 0.32 & 3.99 & 0.33 & 0.33 & 0.66 & 1.65 & 1.64 & 0.00 & 0.00 \\ 0.00 & 0.00 & 0.00 & 0.00 & 0.33 & 0.33 & 0.00 & 0.33 & 0.00 \\ 0.00 & 0.00 & 0.00 & 0.00 & 0.00 & 0.00 & 0.66 & 0.67 & 0.00 \\ 3.55 & 1.66 & 6.59 & 9.67 & 8.91 & 9.74 & 9.36 & 5.67 & 1.49 \\ 0.00 & 1.00 & 0.00 & 0.33 & 0.00 & 0.00 & 0.00 & 0.00 & 0.33 \\ 0.32 & 0.00 & 0.00 & 0.00 & 0.33 & 0.33 & 0.00 & 0.00 & 0.00 \\ 0.00 & 0.00 & 0.66 & 2.00 & 0.33 & 0.99 & 1.64 & 0.67 & 0.99 \\ 0.00 & 0.00 & 0.00 & 0.00 & 0.00 & 0.33 & 0.00 & 0.33 & 0.00 \\ 0.00 & 0.66 & 0.00 & 0.00 & 0.00 & 0.00 & 1.31 & 0.00 & 0.00 \\ 0.00 & 0.66 & 0.66 & 0.00 & 0.00 & 0.00 & 0.33 & 0.33 & 0.00 \\ 1.61 & 3.65 & 0.99 & 2.33 & 1.32 & 1.98 & 4.60 & 4.00 & 1.65 \\ 0.32 & 0.00 & 0.00 & 0.00 & 0.00 & 0.00 & 0.00 & 0.00 & 0.00 \\ 0.65 & 0.00 & 0.00 & 0.00 & 0.66 & 0.99 & 0.33 & 0.00 & 0.33\end{array}$




\begin{tabular}{|c|c|c|c|c|c|c|c|c|}
\hline 26.81 & 26.99 & 27.01 & 27.21 & 27.41 & 27.61 & 27.81 & 28.01 & $\begin{array}{r}28.21 \\
4865\end{array}$ \\
\hline 4732 & 4787 & 4793 & 4809 & 4819 & 4830 & 4841 & 4852 & 4865 \\
\hline 0.00 & 0.33 & 0.00 & 0.00 & 0.00 & 0.00 & 0.00 & 0.00 & 0.00 \\
\hline 0.00 & 0.33 & 0.33 & 0.00 & 0.00 & 0.00 & 0.00 & 0.00 & 0.00 \\
\hline 0.00 & 0.67 & 0.00 & 0.00 & 0.00 & 0.00 & 0.00 & 0.00 & 0.00 \\
\hline 0.00 & 0.00 & 0.00 & 0.65 & 0.00 & 0.00 & 0.00 & 0.00 & 0.00 \\
\hline 0.00 & 0.00 & 0.00 & 0.65 & 0.33 & 0.00 & 0.67 & 0.00 & 1.98 \\
\hline 0.00 & 0.00 & 0.00 & 0.00 & 0.00 & 0.00 & 0.00 & 0.00 & 0.00 \\
\hline 0.00 & 0.00 & 0.00 & 0.65 & 0.99 & 0.00 & 0.00 & 0.66 & 0.33 \\
\hline 0.00 & 0.00 & 0.00 & 0.00 & 0.66 & 0.33 & 0.00 & 0.00 & 0.33 \\
\hline 0.00 & 0.00 & 0.00 & 0.00 & 0.00 & 0.00 & 0.00 & 0.00 & 0.00 \\
\hline 1.98 & 1.33 & 1.33 & 1.31 & 1.81 & 1.00 & 1.67 & 1.31 & 2.31 \\
\hline 0.00 & 0.00 & 0.00 & 0.00 & 0.00 & 0.00 & 0.00 & 0.00 & 0.00 \\
\hline 0.00 & 0.00 & 0.00 & 0.00 & 0.00 & 0.00 & 0.00 & 0.00 & 0.00 \\
\hline 0.00 & 0.00 & 0.00 & 0.00 & 0.00 & 0.00 & 0.00 & 0.00 & 0.33 \\
\hline 0.33 & 0.00 & 0.00 & 0.00 & 0.00 & 0.17 & 0.00 & 0.00 & 0.00 \\
\hline 0.00 & 1.33 & 0.67 & 1.14 & 0.66 & 0.00 & 11.50 & 0.33 & 0.33 \\
\hline 0.00 & 0.33 & 0.00 & 0.00 & 0.00 & 0.00 & 0.00 & 0.00 & 0.00 \\
\hline 0.00 & 0.33 & 0.00 & 0.65 & 0.00 & 0.00 & 0.00 & 0.00 & 0.00 \\
\hline 1.82 & 1.67 & 1.00 & 1.80 & 1.32 & 1.50 & 1.67 & 4.11 & 0.49 \\
\hline 1.98 & 2.33 & 1.00 & 2.61 & 2.63 & 3.00 & 0.00 & 1.31 & 0.33 \\
\hline 0.83 & 0.00 & 2.00 & 0.16 & 1.32 & 1.33 & 0.50 & 0.00 & 1.98 \\
\hline 0.33 & 1.00 & 1.00 & 2.45 & 1.32 & 1.50 & 1.00 & 1.64 & 0.99 \\
\hline 0.00 & 0.00 & 0.00 & 0.00 & 0.00 & 0.00 & 0.33 & 0.00 & 0.00 \\
\hline 1.32 & 1.33 & 0.33 & 0.00 & 1.32 & 2.00 & 2.33 & 1.97 & 3.29 \\
\hline 0.00 & 0.17 & 0.00 & 0.16 & 0.00 & 0.00 & 0.00 & 0.00 & 0.00 \\
\hline 0.00 & 0.00 & 0.17 & 0.16 & 0.00 & 0.00 & 0.00 & 0.00 & 0.00 \\
\hline 0.66 & 0.67 & 0.67 & 0.00 & 0.16 & 0.17 & 0.00 & 1.15 & 0.82 \\
\hline 0.00 & 0.00 & 0.00 & 0.00 & 1.48 & 0.67 & 0.00 & 0.82 & 0.33 \\
\hline 0.00 & 0.67 & 0.33 & 0.65 & 0.16 & 0.67 & 0.17 & 0.66 & 0.49 \\
\hline 2.64 & 4.67 & 2.83 & 6.86 & 6.91 & 7.17 & 8.00 & 4.11 & 7.08 \\
\hline 2.64 & 2.00 & 2.00 & 1.96 & 1.97 & 2.00 & 1.00 & 3.28 & 1.65 \\
\hline 0.00 & 0.00 & 0.00 & 0.00 & 0.00 & 0.00 & 0.00 & 0.00 & 0.00 \\
\hline 0.33 & 0.50 & 0.00 & 0.00 & 0.00 & 0.50 & 0.00 & 0.16 & 0.33 \\
\hline 0.00 & 1.67 & 0.00 & 0.98 & 1.32 & 0.67 & 0.00 & 0.33 & 0.99 \\
\hline 0.33 & 0.83 & 0.83 & 0.16 & 1.81 & 1.33 & 1.83 & 1.81 & 0.99 \\
\hline 0.00 & 0.00 & 0.00 & 0.00 & 0.00 & 0.00 & 0.00 & 0.00 & 0.0 \\
\hline 0.00 & 0.00 & 0.00 & 0.00 & 0.00 & 0.00 & 0.00 & 0.00 & 0.00 \\
\hline 0.00 & 0.00 & 0.00 & 0.00 & 0.00 & 0.00 & 0.00 & 0.00 & 0.00 \\
\hline 0.00 & 0.00 & 0.00 & 0.00 & 0.00 & 0.00 & 0.33 & 0.00 & 0.00 \\
\hline 1.32 & 0.67 & 1.67 & 0.00 & 0.66 & 2.00 & 0.00 & 0.33 & 0.99 \\
\hline 0.00 & 0.00 & 0.00 & 0.00 & 0.00 & 0.00 & 0.00 & 0.00 & 0.00 \\
\hline 0.00 & 0.00 & 0.00 & 0.00 & 0.00 & 0.00 & 0.00 & 0.00 & 0.00 \\
\hline 0.00 & 0.00 & 0.00 & 0.00 & 0.00 & 0.00 & 0.00 & 0.00 & 0.00 \\
\hline 0.00 & 0.00 & 0.00 & 0.00 & 0.00 & 0.00 & 0.00 & 0.00 & 0.00 \\
\hline 0.00 & 0.00 & 0.00 & 0.00 & 0.00 & 0.00 & 0.00 & 0.00 & 0.00 \\
\hline 0.00 & 0.00 & 0.00 & 0.00 & 0.00 & 0.00 & 0.00 & 0.00 & 0.00 \\
\hline 0.00 & 0.00 & 0.00 & 0.65 & 0.00 & 0.00 & 0.00 & 0.00 & 0.00 \\
\hline 3.31 & 1.00 & 3.00 & 0.65 & 1.64 & 2.33 & 0.67 & 0.66 & 1.65 \\
\hline 0.00 & 0.00 & 0.00 & 0.00 & 0.00 & 0.00 & 0.00 & 0.00 & 0.0 \\
\hline
\end{tabular}




$\begin{array}{rrrrrrrrr}64.79 & 61.67 & 62.00 & 57.84 & 48.68 & 49.67 & 47.33 & 55.17 & 56.34 \\ 0.00 & 0.00 & 0.00 & 0.33 & 4.93 & 0.00 & 0.67 & 0.66 & 0.00 \\ 0.00 & 0.33 & 0.00 & 0.00 & 0.00 & 0.67 & 0.33 & 0.00 & 0.00 \\ 0.00 & 0.00 & 0.33 & 0.33 & 0.00 & 0.33 & 0.00 & 0.33 & 0.00 \\ 0.99 & 2.50 & 6.17 & 3.76 & 3.29 & 5.00 & 2.33 & 5.58 & 1.15 \\ 0.00 & 0.00 & 0.00 & 0.00 & 0.00 & 0.00 & 0.00 & 0.00 & 0.00 \\ 0.00 & 0.00 & 0.00 & 0.00 & 0.00 & 0.00 & 0.00 & 0.00 & 0.00 \\ 1.98 & 0.67 & 1.33 & 1.96 & 0.66 & 2.67 & 1.00 & 1.31 & 1.32 \\ 0.00 & 0.00 & 0.00 & 0.33 & 0.00 & 0.67 & 0.00 & 0.33 & 0.00 \\ 0.00 & 0.00 & 0.00 & 0.00 & 0.00 & 0.00 & 0.00 & 0.66 & 0.00 \\ 0.00 & 0.00 & 0.67 & 0.33 & 0.33 & 0.00 & 0.00 & 0.00 & 0.00 \\ 3.31 & 3.33 & 3.33 & 3.92 & 1.97 & 4.00 & 4.33 & 1.64 & 3.95 \\ 0.00 & 0.00 & 0.00 & 0.00 & 0.00 & 0.00 & 0.00 & 0.00 & 0.00 \\ 1.98 & 0.00 & 1.67 & 0.33 & 0.00 & 0.67 & 0.00 & 0.00 & 0.00\end{array}$




\begin{tabular}{|c|c|c|c|c|c|c|c|c|}
\hline 28.415 & 28.615 & 28.81 & 29.01 & 29.22 & 29.415 & 29.615 & 29.75 & $\begin{array}{r}29.805 \\
5184\end{array}$ \\
\hline 4913 & 4959 & 5002 & 5048 & 5096 & 5141 & 5170 & 5180 & 5184 \\
\hline 0.00 & 0.00 & 0.33 & 0.00 & 0.00 & 1.00 & 0.64 & 0.67 & 0.00 \\
\hline 0.33 & 0.00 & 0.00 & 0.00 & 0.00 & 0.33 & 0.16 & 0.00 & 0.00 \\
\hline 0.00 & 0.00 & 0.67 & 0.00 & 0.00 & 0.00 & 0.00 & 0.00 & 0.00 \\
\hline 0.00 & 0.00 & 0.00 & 0.00 & 1.64 & 0.33 & 0.00 & 0.00 & 0.00 \\
\hline 0.33 & 0.00 & 0.00 & 0.33 & 0.00 & 1.00 & 0.00 & 0.00 & 0.33 \\
\hline 0.00 & 0.00 & 0.00 & 0.00 & 0.00 & 0.00 & 0.00 & 0.17 & 0.00 \\
\hline 1.33 & 0.00 & 1.67 & 0.00 & 0.99 & 0.00 & 10.53 & 0.67 & 0.00 \\
\hline 0.00 & 0.16 & 0.00 & 0.17 & 0.00 & 0.00 & 0.32 & 0.33 & 0.00 \\
\hline 0.00 & 0.00 & 0.00 & 0.00 & 0.00 & 0.00 & 0.00 & 0.00 & 0.00 \\
\hline 1.00 & 1.15 & 0.50 & 0.33 & 1.32 & 2.49 & 1.28 & 2.00 & 2.15 \\
\hline 0.00 & 0.00 & 0.17 & 0.00 & 0.16 & 0.00 & 0.00 & 0.50 & 0.00 \\
\hline 0.00 & 0.00 & 0.00 & 0.00 & 0.00 & 0.00 & 0.00 & 0.00 & 0.00 \\
\hline 0.00 & 0.00 & 0.00 & 0.00 & 0.00 & 0.00 & 0.00 & 0.00 & 0.00 \\
\hline 0.00 & 0.00 & 0.00 & 0.00 & 0.00 & 0.00 & 0.32 & 0.33 & 0.00 \\
\hline 1.00 & 0.98 & 0.00 & 7.28 & 0.33 & 1.00 & 0.32 & 1.00 & 2.64 \\
\hline 0.00 & 0.00 & 0.33 & 0.00 & 0.00 & 0.00 & 0.00 & 0.00 & 0.00 \\
\hline 0.00 & 0.00 & 0.00 & 0.00 & 0.33 & 0.00 & 0.00 & 0.33 & 0.00 \\
\hline 1.67 & 2.29 & 1.17 & 1.32 & 3.29 & 2.99 & 2.07 & 2.16 & 0.99 \\
\hline 1.67 & 0.65 & 7.33 & 3.31 & 4.61 & 1.99 & 6.06 & 1.33 & 2.64 \\
\hline 0.00 & 0.00 & 0.00 & 0.00 & 0.00 & 0.66 & 0.32 & 0.17 & 0.33 \\
\hline 2.83 & 2.62 & 1.00 & 1.32 & 2.80 & 3.48 & 2.23 & 1.83 & 2.15 \\
\hline 0.00 & 0.00 & 0.00 & 0.00 & 0.00 & 0.00 & 0.00 & 0.67 & 0.00 \\
\hline 2.00 & 0.65 & 0.67 & 1.66 & 2.96 & 0.00 & 1.91 & 0.33 & 1.98 \\
\hline 0.67 & 0.00 & 0.00 & 0.00 & 0.00 & 0.00 & 0.32 & 0.50 & 0.00 \\
\hline 0.00 & 0.00 & 0.00 & 0.00 & 0.00 & 0.17 & 0.00 & 0.00 & 0.00 \\
\hline 1.67 & 1.15 & 0.33 & 0.50 & 0.33 & 0.00 & 0.64 & 1.50 & 1.32 \\
\hline 0.00 & 0.00 & 0.00 & 0.00 & 0.00 & 0.00 & 0.32 & 0.00 & 0.00 \\
\hline 0.67 & 0.16 & 0.33 & 0.17 & 0.99 & 0.33 & 0.96 & 0.67 & 0.50 \\
\hline 4.83 & 5.07 & 14.67 & 11.09 & 8.39 & 12.77 & 11.80 & 10.98 & 8.43 \\
\hline 3.67 & 1.96 & 3.00 & 3.31 & 2.63 & 4.98 & 0.32 & 4.99 & 3.31 \\
\hline 0.00 & 0.16 & 0.00 & 0.00 & 0.00 & 0.17 & 0.00 & 0.00 & 0.00 \\
\hline 0.17 & 0.16 & 0.00 & 0.33 & 0.99 & 0.66 & 0.32 & 0.67 & 0.50 \\
\hline 0.00 & 0.65 & 1.17 & 0.33 & 1.64 & 0.33 & 0.16 & 2.33 & 0.66 \\
\hline 1.67 & 0.49 & 0.83 & 0.99 & 1.64 & 0.00 & 0.64 & 0.50 & 0.99 \\
\hline 0.00 & 0.00 & 0.00 & 0.00 & 0.00 & 0.00 & 0.00 & 0.00 & 0.00 \\
\hline 0.00 & 0.00 & 0.00 & 0.00 & 0.00 & 0.00 & 0.00 & 0.00 & 0.00 \\
\hline 0.00 & 0.00 & 0.00 & 0.00 & 0.00 & 0.00 & 0.00 & 0.00 & 0.00 \\
\hline 0.33 & 0.00 & 0.00 & 0.00 & 0.00 & 0.00 & 0.00 & 0.00 & 0.00 \\
\hline 1.33 & 0.00 & 0.33 & 0.99 & 0.00 & 0.66 & 2.23 & 1.00 & 0.66 \\
\hline 0.00 & 0.00 & 0.00 & 0.00 & 0.00 & 0.00 & 0.00 & 0.00 & 0.00 \\
\hline 0.00 & 0.00 & 0.00 & 0.00 & 0.00 & 0.00 & 0.32 & 0.00 & 0.33 \\
\hline 0.00 & 0.00 & 0.00 & 0.00 & 0.00 & 0.00 & 0.00 & 0.00 & 0.00 \\
\hline 0.00 & 0.00 & 0.00 & 0.00 & 0.00 & 0.00 & 0.00 & 0.00 & 0.00 \\
\hline 0.00 & 0.00 & 0.00 & 0.00 & 0.00 & 0.00 & 0.32 & 0.00 & 0.00 \\
\hline 0.00 & 0.00 & 0.00 & 0.00 & 0.00 & 0.00 & 0.00 & 0.00 & 0.00 \\
\hline 0.00 & 0.65 & 0.00 & 0.00 & 0.99 & 0.33 & 0.00 & 0.67 & 0.33 \\
\hline 2.00 & 2.95 & 0.33 & 0.66 & 0.99 & 1.99 & 1.28 & 1.00 & 1.32 \\
\hline 0.00 & 0.00 & 0.00 & 0.00 & 0.00 & 0.00 & 0.00 & 0.00 & 0.00 \\
\hline
\end{tabular}




$\begin{array}{rrrrrrrrr}53.33 & 57.28 & 46.67 & 42.05 & 44.41 & 41.79 & 38.28 & 37.60 & 48.60 \\ 0.00 & 0.00 & 0.00 & 0.00 & 0.33 & 0.00 & 0.00 & 3.66 & 0.99 \\ 0.33 & 0.00 & 0.33 & 0.00 & 0.00 & 0.00 & 0.32 & 0.33 & 0.00 \\ 0.00 & 0.33 & 0.00 & 0.00 & 0.66 & 0.00 & 0.32 & 1.00 & 0.00 \\ 3.17 & 2.78 & 3.83 & 7.28 & 3.45 & 8.13 & 4.47 & 7.65 & 3.97 \\ 0.00 & 0.00 & 1.00 & 0.00 & 0.00 & 0.00 & 0.00 & 0.00 & 0.00 \\ 0.00 & 0.00 & 0.00 & 0.33 & 0.66 & 0.00 & 0.00 & 0.00 & 0.00 \\ 1.67 & 0.33 & 0.00 & 1.66 & 0.99 & 2.32 & 0.96 & 1.00 & 0.99 \\ 0.67 & 0.00 & 0.00 & 0.00 & 0.00 & 0.33 & 0.32 & 0.33 & 0.33 \\ 0.00 & 0.00 & 1.00 & 0.33 & 0.66 & 0.00 & 0.32 & 0.00 & 0.00 \\ 0.00 & 0.00 & 0.00 & 0.33 & 0.00 & 0.00 & 0.00 & 0.00 & 0.00 \\ 3.33 & 8.84 & 0.33 & 7.28 & 2.63 & 1.66 & 1.59 & 3.00 & 6.28 \\ 0.00 & 0.00 & 0.67 & 0.00 & 0.00 & 0.00 & 0.00 & 0.00 & 0.00 \\ 0.00 & 0.00 & 0.00 & 0.00 & 1.32 & 0.00 & 0.00 & 0.00 & 0.00\end{array}$




\begin{tabular}{|c|c|c|c|c|c|c|c|c|}
\hline 29.945 & 30.01 & 30.16 & 30.31 & 30.53 & 30.74 & 30.93 & 31.13 & 31.255 \\
\hline 5194 & 5199 & 5209 & 5220 & 5236 & 5252 & 5266 & 5280 & 5290 \\
\hline 0.00 & 0.00 & 0.00 & 0.00 & 0.00 & 0.00 & 0.33 & 0.00 & 0.00 \\
\hline 0.00 & 0.00 & 0.33 & 1.66 & 0.00 & 0.00 & 0.66 & 0.00 & 0.00 \\
\hline 0.00 & 0.00 & 0.00 & 0.00 & 0.00 & 0.00 & 0.00 & 0.00 & 0.00 \\
\hline 0.66 & 0.00 & 0.00 & 0.00 & 0.00 & 0.00 & 1.33 & 0.00 & 0.00 \\
\hline 0.16 & 0.00 & 0.00 & 0.00 & 0.97 & 0.00 & 0.00 & 0.00 & 0.00 \\
\hline 0.00 & 0.00 & 0.00 & 0.00 & 0.00 & 0.00 & 0.00 & 0.00 & 0.00 \\
\hline 1.65 & 0.00 & 0.99 & 0.33 & 0.65 & 0.33 & 0.00 & 2.00 & 0.00 \\
\hline 0.33 & 0.67 & 0.00 & 0.00 & 0.00 & 0.00 & 0.00 & 0.00 & 0.00 \\
\hline 0.00 & 0.00 & 0.00 & 0.00 & 0.00 & 0.00 & 0.00 & 0.00 & 0.00 \\
\hline 1.15 & 1.83 & 1.32 & 0.83 & 1.13 & 0.17 & 0.66 & 0.33 & 2.00 \\
\hline 0.00 & 0.00 & 0.16 & 0.00 & 0.00 & 0.00 & 0.00 & 0.00 & 0.00 \\
\hline 0.00 & 0.00 & 0.00 & 0.00 & 0.00 & 0.00 & 0.00 & 0.00 & 0.00 \\
\hline 0.00 & 0.00 & 0.00 & 0.00 & 0.00 & 0.00 & 0.00 & 0.00 & 0.00 \\
\hline 0.99 & 0.00 & 0.00 & 0.00 & 0.00 & 0.00 & 0.00 & 0.00 & 0.00 \\
\hline 0.00 & 3.00 & 0.66 & 0.83 & 1.29 & 0.67 & 1.66 & 1.34 & 0.00 \\
\hline 0.00 & 0.00 & 0.00 & 0.33 & 0.00 & 0.00 & 0.00 & 0.00 & 0.00 \\
\hline 0.00 & 0.33 & 0.00 & 0.00 & 0.00 & 0.00 & 0.33 & 0.00 & 0.00 \\
\hline 0.99 & 1.50 & 0.66 & 0.66 & 1.13 & 0.67 & 2.66 & 1.34 & 1.33 \\
\hline 2.31 & 4.33 & 1.32 & 2.65 & 1.29 & 1.66 & 4.65 & 3.01 & 1.67 \\
\hline 0.00 & 0.50 & 0.66 & 0.00 & 0.81 & 0.00 & 0.33 & 0.00 & 0.17 \\
\hline 0.82 & 1.33 & 0.99 & 0.66 & 0.00 & 0.67 & 1.33 & 1.00 & 1.33 \\
\hline 0.33 & 0.00 & 0.00 & 0.00 & 0.00 & 0.00 & 0.00 & 0.00 & 0.00 \\
\hline 2.14 & 1.00 & 1.32 & 0.00 & 0.32 & 0.33 & 0.00 & 1.00 & 0.67 \\
\hline 0.00 & 0.33 & 0.00 & 0.00 & 0.00 & 0.00 & 0.33 & 0.00 & 0.33 \\
\hline 0.00 & 0.33 & 0.00 & 0.66 & 0.16 & 0.00 & 0.33 & 0.00 & 0.00 \\
\hline 1.65 & 0.00 & 0.16 & 0.66 & 0.16 & 1.00 & 0.33 & 1.00 & 0.50 \\
\hline 0.00 & 0.67 & 0.00 & 0.00 & 0.00 & 0.00 & 0.00 & 0.00 & 0.33 \\
\hline 0.49 & 1.00 & 0.33 & 0.50 & 0.81 & 0.33 & 0.17 & 1.17 & 0.33 \\
\hline 10.87 & 9.65 & 9.54 & 8.79 & 4.84 & 8.49 & 12.29 & 8.51 & 11.83 \\
\hline 5.93 & 1.66 & 4.61 & 2.32 & 2.58 & 2.00 & 3.32 & 2.00 & 3.67 \\
\hline 0.33 & 0.00 & 0.33 & 0.00 & 0.00 & 0.00 & 0.00 & 0.33 & 0.00 \\
\hline 0.00 & 0.50 & 0.66 & 1.33 & 0.00 & 0.33 & 0.17 & 0.67 & 0.00 \\
\hline 2.97 & 0.67 & 1.32 & 0.66 & 0.97 & 1.00 & 0.00 & 2.00 & 0.67 \\
\hline 0.66 & 0.67 & 1.15 & 1.00 & 0.32 & 1.50 & 0.66 & 0.17 & 0.50 \\
\hline 0.00 & 0.00 & 0.00 & 0.00 & 0.00 & 0.00 & 0.00 & 0.00 & 0.00 \\
\hline 0.00 & 0.00 & 0.00 & 0.00 & 0.00 & 0.00 & 0.00 & 0.00 & 0.00 \\
\hline 0.00 & 0.00 & 0.00 & 0.33 & 0.00 & 0.00 & 0.00 & 0.00 & 0.00 \\
\hline 0.00 & 0.00 & 0.33 & 0.00 & 0.00 & 0.33 & 0.00 & 0.00 & 0.00 \\
\hline 0.66 & 1.66 & 1.97 & 2.32 & 0.00 & 2.66 & 0.66 & 1.34 & 0.33 \\
\hline 0.00 & 0.00 & 0.00 & 0.00 & 0.00 & 0.00 & 0.00 & 0.00 & 0.00 \\
\hline 0.00 & 0.00 & 0.00 & 0.33 & 0.00 & 0.00 & 0.00 & 0.00 & 0.00 \\
\hline 0.00 & 0.00 & 0.00 & 0.00 & 0.00 & 0.00 & 0.00 & 0.00 & 0.00 \\
\hline 0.00 & 0.00 & 0.00 & 0.00 & 0.00 & 0.00 & 0.00 & 0.00 & 0.00 \\
\hline 0.00 & 0.00 & 0.00 & 0.00 & 0.00 & 0.00 & 0.00 & 0.00 & 0.00 \\
\hline 0.00 & 0.00 & 0.00 & 0.00 & 0.00 & 0.00 & 0.00 & 0.00 & 0.00 \\
\hline 0.00 & 2.00 & 0.66 & 1.00 & 0.00 & 0.67 & 0.00 & 0.00 & 0.67 \\
\hline 0.66 & 5.66 & 5.59 & 1.33 & 0.65 & 2.00 & 2.66 & 1.34 & 1.33 \\
\hline 0.00 & 0.00 & 0.00 & 0.00 & 0.00 & 0.00 & 0.00 & 0.00 & 0.00 \\
\hline
\end{tabular}




$\begin{array}{rrrrrrrrr}35.26 & 31.95 & 46.05 & 48.76 & 72.26 & 49.92 & 35.55 & 42.40 & 51.67 \\ 0.66 & 3.99 & 0.33 & 0.00 & 0.32 & 0.00 & 0.33 & 0.67 & 0.00 \\ 0.00 & 0.33 & 0.00 & 0.00 & 0.00 & 0.00 & 0.33 & 0.33 & 0.00 \\ 0.66 & 0.00 & 0.00 & 0.00 & 0.32 & 0.00 & 0.66 & 0.33 & 0.33 \\ 11.70 & 7.32 & 4.77 & 9.78 & 2.10 & 15.97 & 7.64 & 13.52 & 9.83 \\ 0.00 & 0.00 & 0.00 & 0.00 & 0.00 & 0.00 & 0.00 & 0.00 & 0.00 \\ 0.00 & 0.33 & 0.00 & 0.00 & 0.00 & 0.00 & 0.00 & 0.00 & 0.00 \\ 1.32 & 0.33 & 1.32 & 1.00 & 0.00 & 0.33 & 0.33 & 0.33 & 0.67 \\ 0.33 & 0.33 & 0.00 & 0.00 & 0.32 & 0.00 & 0.00 & 0.67 & 0.00 \\ 0.33 & 0.00 & 0.00 & 0.00 & 0.00 & 0.00 & 5.32 & 0.00 & 0.00 \\ 0.33 & 0.33 & 0.33 & 0.00 & 0.32 & 0.00 & 0.00 & 0.00 & 0.33 \\ 3.95 & 2.33 & 3.95 & 4.64 & 1.61 & 2.00 & 2.33 & 6.01 & 1.00 \\ 0.00 & 0.00 & 0.00 & 0.00 & 0.00 & 0.00 & 0.00 & 0.00 & 0.00 \\ 0.00 & 0.33 & 0.00 & 0.00 & 0.00 & 0.00 & 0.00 & 0.00 & 0.00\end{array}$




\begin{tabular}{|c|c|c|c|c|c|c|c|c|}
\hline 31.75 & 31.97 & 32.17 & 32.37 & 32.57 & 32.77 & 32.92 & 32.97 & 33.09 \\
\hline 5325 & 5350 & 5375 & 5388 & 5425 & 5450 & 5496 & 5475 & 5490 \\
\hline 0.00 & 0.00 & 0.00 & 0.00 & 0.00 & 0.00 & 0.33 & 0.00 & 0.00 \\
\hline 0.00 & 0.00 & 0.00 & 0.67 & 0.33 & 0.00 & 0.83 & 0.33 & 0.00 \\
\hline 0.00 & 0.00 & 0.00 & 0.00 & 0.00 & 0.00 & 0.00 & 0.00 & 0.00 \\
\hline 0.65 & 0.65 & 0.00 & 1.00 & 0.00 & 0.00 & 0.83 & 0.00 & 0.00 \\
\hline 0.00 & 0.00 & 0.00 & 0.00 & 0.00 & 0.00 & 1.33 & 0.00 & 0.66 \\
\hline 0.00 & 0.00 & 0.00 & 0.00 & 0.00 & 0.00 & 0.00 & 0.00 & 0.00 \\
\hline 0.00 & 0.00 & 0.65 & 0.67 & 0.66 & 1.32 & 0.00 & 0.33 & 0.33 \\
\hline 0.00 & 0.33 & 0.00 & 0.00 & 0.00 & 0.00 & 0.33 & 0.33 & 0.00 \\
\hline 0.00 & 0.00 & 0.00 & 0.00 & 0.00 & 0.00 & 0.00 & 0.00 & 0.00 \\
\hline 1.14 & 0.82 & 0.16 & 0.33 & 1.49 & 0.99 & 1.17 & 1.16 & 1.48 \\
\hline 0.00 & 0.16 & 0.00 & 0.00 & 0.00 & 0.00 & 0.00 & 0.00 & 0.00 \\
\hline 0.00 & 0.00 & 0.00 & 0.00 & 0.00 & 0.00 & 1.33 & 0.00 & 0.00 \\
\hline 0.00 & 0.00 & 0.00 & 0.00 & 0.00 & 0.00 & 0.00 & 0.00 & 0.00 \\
\hline 0.00 & 0.00 & 0.00 & 0.00 & 0.00 & 0.33 & 0.00 & 0.00 & 0.33 \\
\hline 0.33 & 0.65 & 0.00 & 0.67 & 2.97 & 1.66 & 1.17 & 0.66 & 0.33 \\
\hline 0.00 & 0.00 & 0.00 & 0.00 & 0.00 & 0.00 & 0.00 & 0.00 & 0.00 \\
\hline 0.00 & 0.16 & 0.00 & 0.00 & 0.00 & 0.66 & 0.33 & 0.00 & 0.00 \\
\hline 1.31 & 1.96 & 0.65 & 2.17 & 1.32 & 1.82 & 0.83 & 1.49 & 0.99 \\
\hline 0.98 & 3.92 & 1.63 & 2.01 & 1.65 & 1.32 & 6.33 & 0.33 & 1.98 \\
\hline 0.00 & 0.16 & 0.00 & 1.00 & 0.00 & 0.50 & 0.00 & 0.00 & 0.33 \\
\hline 0.00 & 0.98 & 0.49 & 0.67 & 1.98 & 2.32 & 0.33 & 1.99 & 0.33 \\
\hline 0.00 & 0.00 & 0.00 & 0.00 & 0.00 & 0.00 & 0.00 & 0.00 & 0.00 \\
\hline 1.63 & 3.92 & 5.54 & 3.68 & 1.65 & 0.00 & 2.50 & 0.66 & 0.00 \\
\hline 0.00 & 0.16 & 0.00 & 0.00 & 0.17 & 0.33 & 0.00 & 0.00 & 0.00 \\
\hline 0.00 & 0.82 & 0.00 & 0.00 & 0.33 & 0.33 & 0.50 & 0.17 & 0.33 \\
\hline 0.33 & 0.16 & 0.33 & 1.34 & 1.32 & 1.16 & 0.50 & 0.33 & 0.99 \\
\hline 0.00 & 0.00 & 0.00 & 0.50 & 0.00 & 0.00 & 0.00 & 2.65 & 0.66 \\
\hline 1.14 & 0.98 & 1.63 & 0.84 & 0.33 & 0.66 & 1.17 & 0.50 & 0.49 \\
\hline 7.34 & 6.04 & 8.79 & 10.03 & 9.57 & 8.28 & 7.50 & 5.63 & 9.39 \\
\hline 2.28 & 3.59 & 1.95 & 3.01 & 2.97 & 2.65 & 4.00 & 2.98 & 2.31 \\
\hline 0.00 & 0.00 & 0.00 & 0.00 & 0.00 & 0.00 & 0.00 & 0.00 & 0.00 \\
\hline 0.00 & 0.33 & 1.63 & 2.01 & 0.33 & 0.33 & 0.33 & 0.00 & 0.99 \\
\hline 0.00 & 0.65 & 1.30 & 0.00 & 0.66 & 4.97 & 0.33 & 0.00 & 0.66 \\
\hline 0.33 & 0.33 & 0.98 & 0.84 & 1.49 & 0.99 & 0.00 & 0.83 & 0.99 \\
\hline 0.00 & 0.00 & 0.00 & 0.00 & 0.00 & 0.00 & 0.00 & 0.00 & 0.00 \\
\hline 0.00 & 0.00 & 0.00 & 0.00 & 0.00 & 0.00 & 0.00 & 0.00 & 0.00 \\
\hline 0.00 & 0.00 & 0.00 & 0.00 & 0.00 & 0.00 & 0.00 & 0.00 & 0.00 \\
\hline 0.00 & 0.65 & 0.00 & 0.00 & 0.00 & 0.00 & 0.00 & 0.00 & 0.00 \\
\hline 1.31 & 0.65 & 1.63 & 2.01 & 0.00 & 0.00 & 1.00 & 0.66 & 0.00 \\
\hline 0.00 & 0.00 & 0.00 & 0.00 & 0.00 & 0.00 & 0.00 & 0.00 & 0.00 \\
\hline 0.00 & 0.00 & 0.00 & 0.00 & 0.00 & 0.00 & 0.00 & 0.00 & 0.00 \\
\hline 0.00 & 0.00 & 0.00 & 0.00 & 0.00 & 0.00 & 0.00 & 0.00 & 0.00 \\
\hline 0.00 & 0.00 & 0.00 & 0.00 & 0.00 & 0.00 & 0.00 & 0.00 & 0.00 \\
\hline 0.00 & 0.00 & 0.00 & 0.00 & 0.00 & 0.00 & 0.00 & 0.00 & 0.00 \\
\hline 0.00 & 0.00 & 0.00 & 0.00 & 0.00 & 0.00 & 0.00 & 0.00 & 0.00 \\
\hline 0.33 & 0.33 & 0.33 & 0.00 & 0.66 & 0.99 & 0.67 & 0.66 & 0.00 \\
\hline 0.33 & 1.96 & 1.30 & 2.01 & 2.64 & 0.00 & 3.00 & 0.00 & 1.65 \\
\hline 0 & 0.00 & DO & 0.00 & 0.00 & 0.00 & 0.00 & 0.33 & 0 \\
\hline
\end{tabular}




$\begin{array}{rrrrrrrrr}64.60 & 44.37 & 44.95 & 34.45 & 45.87 & 42.72 & 31.00 & 51.32 & 40.53 \\ 0.00 & 0.33 & 0.33 & 0.67 & 0.33 & 0.33 & 1.33 & 0.00 & 0.33 \\ 0.00 & 0.00 & 0.00 & 0.00 & 0.33 & 0.33 & 0.00 & 0.33 & 0.00 \\ 0.00 & 0.65 & 0.00 & 0.33 & 0.00 & 0.00 & 0.00 & 0.00 & 0.00 \\ 2.61 & 10.11 & 11.73 & 8.03 & 5.45 & 1.49 & 16.50 & 6.79 & 6.59 \\ 0.00 & 0.00 & 0.00 & 0.00 & 0.00 & 0.00 & 0.00 & 0.00 & 0.00 \\ 0.00 & 0.00 & 0.00 & 0.00 & 0.33 & 0.00 & 0.00 & 0.00 & 0.00 \\ 2.28 & 0.65 & 0.33 & 1.34 & 1.32 & 0.99 & 1.00 & 0.99 & 0.33 \\ 0.33 & 0.00 & 0.65 & 0.00 & 0.33 & 0.33 & 0.00 & 0.00 & 0.66 \\ 0.65 & 0.00 & 0.33 & 0.67 & 0.99 & 2.32 & 0.33 & 1.66 & 0.00 \\ 0.00 & 0.00 & 0.00 & 1.00 & 0.00 & 0.00 & 0.33 & 0.00 & 0.00 \\ 3.59 & 4.89 & 4.23 & 6.02 & 4.29 & 9.60 & 3.00 & 8.61 & 16.47 \\ 0.00 & 0.00 & 0.00 & 0.00 & 0.00 & 0.00 & 0.00 & 0.00 & 0.00 \\ 0.33 & 0.00 & 0.00 & 0.00 & 0.33 & 0.00 & 0.00 & 0.00 & 0.00\end{array}$




\begin{tabular}{|c|c|c|c|c|c|c|c|c|}
\hline $\begin{array}{r}33.32 \\
5519\end{array}$ & $\begin{array}{r}33.52 \\
5544\end{array}$ & $\begin{array}{r}33.72 \\
5569\end{array}$ & $\begin{array}{r}33.92 \\
5594\end{array}$ & $\begin{array}{r}34.12 \\
5624\end{array}$ & $\begin{array}{r}34.31 \\
5663\end{array}$ & $\begin{array}{r}34.5 \\
5701\end{array}$ & $\begin{array}{r}34.65 \\
5731\end{array}$ & $\begin{array}{r}34.7 \\
5742\end{array}$ \\
\hline 0.00 & 0.00 & 0.00 & 0.00 & 0.00 & 0.00 & 0.00 & 0.00 & 0.00 \\
\hline 0.33 & 0.00 & 0.33 & 0.00 & 0.33 & 0.33 & 0.64 & 0.33 & 0.00 \\
\hline 0.00 & 0.00 & 0.00 & 0.00 & 0.00 & 0.00 & 0.00 & 0.00 & 0.00 \\
\hline 0.65 & 0.33 & 0.00 & 0.00 & 0.00 & 0.00 & 0.00 & 0.00 & 0.00 \\
\hline 0.00 & 0.00 & 0.00 & 0.00 & 0.00 & 0.33 & 0.00 & 0.33 & 0.00 \\
\hline 0.00 & 0.00 & 0.00 & 0.00 & 0.00 & 0.00 & 0.00 & 0.00 & 0.00 \\
\hline 0.00 & 0.00 & 0.33 & 0.66 & 0.33 & 0.00 & 1.28 & 0.33 & 0.00 \\
\hline 0.00 & 0.00 & 0.00 & 0.00 & 0.00 & 0.00 & 0.64 & 0.00 & 0.00 \\
\hline 0.00 & 0.00 & 0.00 & 0.00 & 0.00 & 0.00 & 0.00 & 0.00 & 0.00 \\
\hline 1.47 & 1.66 & 0.33 & 2.80 & 0.16 & 1.50 & 0.64 & 1.15 & 0.98 \\
\hline 0.00 & 0.00 & 0.00 & 0.00 & 0.00 & 0.00 & 0.00 & 0.00 & 0.00 \\
\hline 0.00 & 0.00 & 0.00 & 0.00 & 0.00 & 0.00 & 0.00 & 0.00 & 0.00 \\
\hline 0.00 & 0.00 & 0.00 & 0.00 & 0.00 & 0.00 & 0.00 & 0.00 & 0.00 \\
\hline 0.33 & 0.00 & 0.00 & 0.66 & 0.00 & 0.33 & 0.64 & 0.33 & 0.00 \\
\hline 1.31 & 1.32 & 0.66 & 0.00 & 0.99 & 1.00 & 0.32 & 0.00 & 0.33 \\
\hline 0.00 & 0.00 & 0.00 & 0.00 & 0.00 & 0.00 & 0.00 & 0.00 & 0.00 \\
\hline 0.00 & 0.00 & 0.00 & 0.00 & 0.00 & 0.00 & 0.00 & 0.00 & 0.00 \\
\hline 2.29 & 2.65 & 0.66 & 1.15 & 1.48 & 2.33 & 1.93 & 0.66 & 1.64 \\
\hline 2.61 & 2.32 & 7.24 & 0.00 & 2.30 & 1.00 & 2.25 & 1.32 & 0.33 \\
\hline 0.16 & 0.00 & 0.00 & 0.16 & 1.81 & 1.00 & 0.80 & 0.99 & 0.00 \\
\hline 0.98 & 2.32 & 0.99 & 0.66 & 1.97 & 2.00 & 2.57 & 0.33 & 0.82 \\
\hline 0.00 & 0.00 & 0.00 & 0.00 & 0.00 & 0.00 & 0.00 & 0.00 & 0.00 \\
\hline 0.98 & 0.99 & 1.32 & 0.00 & 2.63 & 2.67 & 0.64 & 0.00 & 0.33 \\
\hline 0.98 & 0.00 & 0.49 & 0.00 & 0.82 & 0.00 & 0.16 & 0.16 & 0.00 \\
\hline 0.00 & 0.33 & 0.00 & 0.00 & 0.00 & 0.33 & 0.00 & 0.33 & 0.33 \\
\hline 0.65 & 0.99 & 1.15 & 0.00 & 0.66 & 0.33 & 0.16 & 1.48 & 0.98 \\
\hline 0.00 & 0.00 & 0.33 & 0.33 & 0.00 & 0.00 & 0.00 & 0.66 & 0.00 \\
\hline 0.00 & 0.50 & 0.82 & 0.66 & 1.32 & 0.33 & 0.32 & 0.66 & 0.98 \\
\hline 6.70 & 5.63 & 11.02 & 9.56 & 13.16 & 8.17 & 7.06 & 8.24 & 6.55 \\
\hline 2.94 & 0.99 & 2.96 & 1.32 & 3.95 & 1.00 & 3.85 & 2.31 & 4.91 \\
\hline 0.00 & 0.00 & 0.00 & 0.00 & 0.00 & 0.00 & 0.00 & 0.00 & 0.00 \\
\hline 0.98 & 0.66 & 0.33 & 0.00 & 0.33 & 0.33 & 0.64 & 0.00 & 0.33 \\
\hline 0.00 & 0.66 & 0.00 & 0.00 & 0.00 & 0.00 & 0.00 & 0.00 & 0.00 \\
\hline 1.14 & 1.32 & 0.49 & 0.33 & 1.97 & 1.67 & 1.44 & 2.14 & 0.33 \\
\hline 0.00 & 0.00 & 0.00 & 0.00 & 0.00 & 0.00 & 0.00 & 0.00 & 0.00 \\
\hline 0.00 & 0.00 & 0.00 & 0.00 & 0.00 & 0.00 & 0.00 & 0.00 & 0.65 \\
\hline 0.00 & 0.00 & 0.00 & 0.00 & 0.00 & 0.00 & 0.00 & 0.00 & 0.00 \\
\hline 0.00 & 0.00 & 0.00 & 0.00 & 0.00 & 0.00 & 0.00 & 0.00 & 0.00 \\
\hline 0.98 & 0.99 & 0.00 & 1.65 & 1.32 & 0.33 & 0.64 & 1.65 & 0.98 \\
\hline 0.00 & 0.00 & 0.00 & 0.00 & 0.00 & 0.00 & 0.00 & 0.00 & 0.00 \\
\hline 0.00 & 0.00 & 0.00 & 0.00 & 0.00 & 0.00 & 0.00 & 0.00 & 0.00 \\
\hline 0.00 & 0.00 & 0.00 & 0.00 & 0.00 & 0.00 & 0.00 & 0.00 & 0.00 \\
\hline 0.00 & 0.00 & 0.00 & 0.00 & 0.00 & 0.00 & 0.00 & 0.00 & 0.00 \\
\hline 0.33 & 0.00 & 0.00 & 0.00 & 0.00 & 0.00 & 0.00 & 0.00 & 0.00 \\
\hline 0.00 & 0.00 & 0.00 & 0.00 & 0.00 & 0.00 & 0.00 & 0.00 & 0.00 \\
\hline 2.29 & 1.66 & 0.99 & 1.32 & 1.32 & 2.00 & 1.61 & 2.97 & 1.31 \\
\hline 0.33 & 0.00 & 1.97 & 4.61 & 0.99 & 0.33 & 1.61 & 0.99 & 1.64 \\
\hline 0 & 0.00 & 0 & 0.00 & 00 & 0.00 & 0.00 & 0 & 0.00 \\
\hline
\end{tabular}




$\begin{array}{rrrrrrrrr}40.20 & 43.38 & 45.07 & 40.86 & 37.17 & 44.33 & 37.24 & 41.85 & 46.81 \\ 0.65 & 1.99 & 0.33 & 0.99 & 0.33 & 3.00 & 0.00 & 0.33 & 0.65 \\ 0.00 & 0.00 & 0.00 & 0.00 & 0.00 & 0.00 & 0.00 & 0.00 & 0.00 \\ 0.00 & 0.00 & 0.00 & 0.00 & 0.00 & 0.00 & 0.32 & 0.00 & 0.00 \\ 15.20 & 11.59 & 6.41 & 18.12 & 4.61 & 4.83 & 8.35 & 3.46 & 6.22 \\ 0.00 & 0.00 & 0.00 & 0.00 & 0.33 & 0.00 & 0.00 & 0.00 & 0.33 \\ 0.00 & 0.00 & 0.00 & 0.00 & 0.00 & 0.00 & 0.00 & 0.00 & 0.00 \\ 0.98 & 0.66 & 0.99 & 0.66 & 0.66 & 2.67 & 4.49 & 2.31 & 1.31 \\ 0.00 & 0.00 & 0.00 & 0.00 & 0.00 & 2.67 & 0.00 & 0.33 & 0.33 \\ 1.96 & 0.00 & 0.00 & 0.00 & 2.30 & 0.33 & 0.00 & 0.33 & 0.98 \\ 0.33 & 0.33 & 0.00 & 0.00 & 1.32 & 0.33 & 0.00 & 0.00 & 0.33 \\ 3.92 & 7.28 & 7.89 & 2.97 & 5.59 & 5.33 & 9.95 & 8.24 & 10.80 \\ 0.00 & 0.00 & 0.00 & 0.00 & 0.00 & 0.00 & 0.00 & 0.00 & 0.00 \\ 0.00 & 0.00 & 0.00 & 0.00 & 0.00 & 0.00 & 0.32 & 0.00 & 0.00\end{array}$




\begin{tabular}{|c|c|c|c|c|c|c|c|c|}
\hline 35.05 & 35.25 & 35.29 & 36.16 & 36.35 & 36.55 & 36.93 & 37.11 & 37.15 \\
\hline 5812 & 5853 & 5861 & 5997 & 6026 & 6056 & 6114 & 6141 & 6147 \\
\hline 0.00 & 0.00 & 0.00 & 0.00 & 0.00 & 0.00 & 0.33 & 0.00 & 0.33 \\
\hline 1.50 & 0.00 & 0.00 & 0.33 & 0.00 & 0.32 & 0.33 & 0.00 & 0.17 \\
\hline 0.00 & 0.00 & 0.00 & 0.00 & 0.00 & 0.00 & 0.00 & 0.00 & 0.00 \\
\hline 0.33 & 0.00 & 0.33 & 0.00 & 0.00 & 0.00 & 0.00 & 0.00 & 0.17 \\
\hline 2.66 & 0.33 & 0.00 & 0.66 & 0.00 & 0.00 & 0.00 & 0.67 & 1.32 \\
\hline 0.00 & 0.00 & 0.00 & 0.00 & 0.00 & 0.00 & 0.00 & 0.00 & 0.17 \\
\hline 0.33 & 0.33 & 0.00 & 0.33 & 0.00 & 0.64 & 0.67 & 0.00 & 2.31 \\
\hline 0.83 & 0.00 & 0.00 & 0.00 & 0.00 & 0.32 & 0.33 & 0.00 & 0.00 \\
\hline 0.00 & 0.00 & 0.00 & 0.00 & 0.00 & 0.00 & 0.00 & 0.00 & 0.00 \\
\hline 0.50 & 1.32 & 1.96 & 1.33 & 0.99 & 0.64 & 1.00 & 1.50 & 0.66 \\
\hline 0.00 & 0.17 & 0.00 & 0.00 & 0.00 & 0.00 & 0.00 & 0.00 & 0.17 \\
\hline 0.00 & 0.00 & 0.00 & 0.00 & 0.00 & 0.00 & 0.00 & 0.00 & 0.00 \\
\hline 0.00 & 0.00 & 0.00 & 0.00 & 0.00 & 0.00 & 0.00 & 0.00 & 0.00 \\
\hline 0.00 & 0.00 & 0.00 & 0.33 & 0.00 & 0.00 & 0.00 & 0.00 & 0.00 \\
\hline 1.00 & 2.48 & 0.00 & 0.00 & 0.00 & 1.28 & 1.00 & 0.33 & 0.00 \\
\hline 0.66 & 0.00 & 0.00 & 0.00 & 0.00 & 0.00 & 0.00 & 0.00 & 0.99 \\
\hline 0.33 & 0.00 & 0.65 & 0.00 & 0.00 & 0.00 & 0.00 & 0.33 & 0.00 \\
\hline 1.50 & 1.66 & 2.45 & 1.16 & 1.16 & 0.80 & 1.67 & 1.50 & 1.65 \\
\hline 1.99 & 3.31 & 0.98 & 1.66 & 1.99 & 2.57 & 0.67 & 1.00 & 1.65 \\
\hline 0.00 & 1.16 & 0.16 & 0.33 & 0.33 & 0.32 & 0.00 & 0.50 & 0.00 \\
\hline 0.33 & 0.99 & 1.63 & 3.98 & 2.32 & 1.77 & 2.33 & 1.33 & 2.15 \\
\hline 0.00 & 0.00 & 0.00 & 0.00 & 0.00 & 0.00 & 0.33 & 0.00 & 0.00 \\
\hline 0.66 & 0.00 & 0.00 & 0.00 & 2.32 & 1.93 & 1.67 & 0.00 & 0.00 \\
\hline 0.00 & 0.00 & 0.00 & 0.00 & 0.00 & 0.16 & 0.00 & 0.00 & 0.00 \\
\hline 0.00 & 0.00 & 0.00 & 0.17 & 0.17 & 0.00 & 0.67 & 0.00 & 0.33 \\
\hline 0.17 & 0.33 & 0.82 & 0.17 & 1.16 & 0.80 & 0.33 & 0.00 & 0.00 \\
\hline 0.00 & 0.00 & 0.00 & 0.00 & 0.00 & 0.00 & 0.00 & 0.00 & 0.00 \\
\hline 0.33 & 0.66 & 1.47 & 0.83 & 0.17 & 0.64 & 1.67 & 0.83 & 0.50 \\
\hline 12.46 & 9.93 & 10.29 & 12.11 & 8.28 & 7.38 & 11.17 & 13.67 & 6.60 \\
\hline 3.32 & 2.32 & 8.17 & 2.65 & 3.31 & 3.21 & 1.33 & 0.00 & 3.30 \\
\hline 0.33 & 0.00 & 0.00 & 0.00 & 0.00 & 0.00 & 0.00 & 0.00 & 0.00 \\
\hline 0.33 & 0.33 & 0.00 & 0.33 & 0.00 & 0.00 & 0.00 & 0.33 & 0.50 \\
\hline 1.16 & 0.66 & 0.65 & 1.66 & 1.32 & 1.61 & 0.00 & 2.50 & 0.66 \\
\hline 0.66 & 0.00 & 0.65 & 2.65 & 1.82 & 1.77 & 0.67 & 0.67 & 0.66 \\
\hline 0.00 & 0.00 & 0.00 & 0.00 & 0.00 & 0.00 & 0.00 & 0.00 & 0.00 \\
\hline 0.00 & 0.00 & 0.00 & 0.00 & 0.33 & 0.00 & 0.00 & 0.33 & 0.00 \\
\hline 0.33 & 0.00 & 0.00 & 0.00 & 0.00 & 0.00 & 0.00 & 0.00 & 0.00 \\
\hline 0.00 & 0.00 & 0.33 & 0.00 & 0.00 & 0.00 & 0.33 & 0.33 & 0.00 \\
\hline 1.66 & 0.33 & 0.33 & 0.00 & 0.00 & 0.64 & 0.00 & 0.33 & 0.00 \\
\hline 0.00 & 0.00 & 0.33 & 0.00 & 0.00 & 0.00 & 0.00 & 0.00 & 0.00 \\
\hline 0.00 & 0.00 & 0.00 & 0.00 & 0.00 & 0.00 & 0.00 & 0.00 & 0.00 \\
\hline 0.00 & 0.00 & 0.00 & 0.00 & 0.00 & 0.00 & 0.00 & 0.00 & 0.00 \\
\hline 0.00 & 0.00 & 0.00 & 0.00 & 0.00 & 0.00 & 0.00 & 0.00 & 0.00 \\
\hline 0.33 & 0.00 & 0.00 & 0.00 & 0.00 & 0.00 & 0.00 & 0.00 & 0.00 \\
\hline 0.00 & 0.00 & 0.00 & 0.00 & 0.00 & 0.00 & 0.00 & 0.00 & 0.00 \\
\hline 3.99 & 3.97 & 4.90 & 3.65 & 2.98 & 2.57 & 4.00 & 2.67 & 0.99 \\
\hline 1.66 & 0.00 & 0.33 & 0.33 & 0.99 & 1.28 & 0.00 & 0.67 & 2.9 \\
\hline 0.00 & 0.00 & 0.00 & 0.00 & 0.00 & 0.00 & 0.00 & 0.00 & 0.0 \\
\hline
\end{tabular}




$\begin{array}{rrrrrrrrr}28.24 & 30.79 & 36.93 & 34.49 & 50.00 & 30.82 & 50.00 & 34.67 & 42.57 \\ 0.66 & 0.00 & 0.00 & 0.33 & 0.33 & 0.00 & 0.00 & 0.33 & 0.00 \\ 0.00 & 0.33 & 0.00 & 0.00 & 0.00 & 0.00 & 0.00 & 0.00 & 0.00 \\ 0.33 & 0.00 & 0.00 & 0.00 & 0.00 & 0.32 & 0.00 & 0.33 & 0.00 \\ 13.12 & 21.69 & 3.10 & 12.60 & 4.47 & 17.98 & 8.00 & 10.83 & 10.89 \\ 0.00 & 0.66 & 0.33 & 0.00 & 0.00 & 0.00 & 0.00 & 0.00 & 0.33 \\ 0.00 & 0.00 & 0.98 & 0.00 & 0.00 & 0.00 & 0.00 & 0.00 & 0.33 \\ 1.66 & 0.33 & 3.92 & 1.33 & 0.99 & 1.93 & 0.33 & 1.67 & 0.33 \\ 0.00 & 0.00 & 1.31 & 0.33 & 0.66 & 0.32 & 0.00 & 0.33 & 1.32 \\ 2.99 & 0.00 & 0.00 & 0.00 & 0.00 & 0.64 & 0.00 & 0.00 & 0.33 \\ 0.00 & 0.66 & 0.33 & 0.00 & 0.00 & 0.64 & 0.00 & 0.00 & 0.66 \\ 4.65 & 4.64 & 6.21 & 7.30 & 2.65 & 10.27 & 3.33 & 8.00 & 7.26 \\ 0.00 & 0.00 & 0.00 & 0.66 & 0.00 & 0.00 & 0.00 & 0.00 & 0.00 \\ 0.00 & 0.00 & 0.00 & 0.33 & 0.00 & 0.00 & 0.00 & 0.00 & 0.00\end{array}$




\begin{tabular}{|c|c|c|c|c|c|c|c|c|}
\hline 37.34 & 37.51 & 37.54 & 37.71 & 37.74 & 37.86 & 37.91 & 37.95 & $\begin{array}{r}38.01 \\
6276\end{array}$ \\
\hline 6175 & 6201 & 6206 & 6231 & 6236 & 6255 & 6261 & 6267 & 6276 \\
\hline 0.00 & 0.00 & 0.00 & 0.00 & 1.33 & 0.00 & 0.00 & 0.00 & 0.00 \\
\hline 0.33 & 0.00 & 0.17 & 0.00 & 0.67 & 1.00 & 0.17 & 0.00 & 0.33 \\
\hline 0.00 & 0.00 & 0.00 & 0.00 & 0.00 & 0.33 & 0.00 & 0.00 & 0.00 \\
\hline 0.67 & 0.00 & 0.00 & 0.00 & 0.00 & 0.17 & 0.00 & 0.00 & 0.00 \\
\hline 0.33 & 0.00 & 0.33 & 3.53 & 0.00 & 0.33 & 0.66 & 0.33 & 0.00 \\
\hline 0.00 & 0.00 & 0.00 & 0.00 & 0.00 & 0.00 & 0.00 & 0.00 & 0.17 \\
\hline 0.00 & 0.66 & 1.00 & 0.64 & 1.33 & 0.00 & 0.99 & 1.63 & 0.00 \\
\hline 0.33 & 0.00 & 0.17 & 0.00 & 0.33 & 0.00 & 0.00 & 0.00 & 0.00 \\
\hline 0.00 & 0.00 & 0.00 & 0.00 & 0.00 & 0.00 & 0.00 & 0.00 & 0.00 \\
\hline 1.50 & 0.83 & 1.00 & 0.64 & 0.50 & 0.67 & 0.66 & 1.79 & 0.83 \\
\hline 0.00 & 0.17 & 0.00 & 0.00 & 0.00 & 0.00 & 0.00 & 0.16 & 0.00 \\
\hline 0.00 & 0.00 & 0.00 & 0.00 & 0.33 & 0.00 & 0.00 & 0.00 & 0.00 \\
\hline 0.00 & 0.00 & 0.00 & 0.00 & 0.00 & 0.00 & 0.00 & 0.00 & 0.00 \\
\hline 0.67 & 0.33 & 0.00 & 0.00 & 0.00 & 0.00 & 0.00 & 0.65 & 0.00 \\
\hline 0.67 & 0.99 & 0.67 & 1.92 & 1.00 & 0.33 & 0.66 & 2.60 & 1.33 \\
\hline 0.00 & 0.00 & 0.00 & 0.00 & 0.00 & 0.00 & 0.00 & 0.00 & 0.00 \\
\hline 0.33 & 0.00 & 0.67 & 0.00 & 0.00 & 0.67 & 0.00 & 0.00 & 0.00 \\
\hline 2.00 & 0.99 & 1.00 & 0.48 & 1.50 & 1.00 & 0.99 & 0.98 & 2.17 \\
\hline 3.67 & 0.66 & 1.33 & 0.00 & 4.99 & 1.66 & 0.33 & 1.30 & 2.00 \\
\hline 1.17 & 0.33 & 0.00 & 0.00 & 0.17 & 0.00 & 0.33 & 0.16 & 0.83 \\
\hline 4.67 & 1.82 & 1.00 & 1.28 & 1.66 & 1.00 & 2.98 & 2.60 & 1.17 \\
\hline 0.00 & 0.00 & 0.33 & 0.00 & 0.33 & 0.00 & 0.00 & 0.00 & 0.00 \\
\hline 1.33 & 0.33 & 0.33 & 2.24 & 0.67 & 0.00 & 0.00 & 0.00 & 0.00 \\
\hline 0.17 & 0.00 & 0.00 & 0.16 & 0.00 & 0.00 & 0.00 & 0.00 & 0.00 \\
\hline 0.00 & 0.17 & 1.83 & 0.32 & 0.83 & 0.67 & 0.00 & 0.33 & 0.00 \\
\hline 0.67 & 0.00 & 0.50 & 1.28 & 1.50 & 0.33 & 0.17 & 0.81 & 0.83 \\
\hline 0.00 & 0.00 & 0.00 & 0.64 & 0.00 & 0.00 & 0.66 & 0.65 & 0.00 \\
\hline 0.83 & 0.66 & 0.33 & 0.32 & 0.50 & 0.00 & 0.66 & 0.98 & 0.00 \\
\hline 9.00 & 6.95 & 6.32 & 8.81 & 10.82 & 12.31 & 6.61 & 8.78 & 10.17 \\
\hline 5.67 & 0.99 & 3.33 & 2.24 & 5.32 & 2.66 & 1.98 & 1.95 & 1.67 \\
\hline 0.00 & 0.33 & 0.00 & 0.00 & 0.00 & 0.00 & 0.00 & 0.00 & 0.00 \\
\hline 0.50 & 0.33 & 0.17 & 0.96 & 0.00 & 0.17 & 0.99 & 0.00 & 0.50 \\
\hline 0.67 & 0.66 & 0.00 & 0.00 & 0.00 & 0.67 & 1.32 & 0.00 & 1.33 \\
\hline 0.83 & 0.50 & 0.17 & 0.64 & 0.83 & 0.50 & 0.33 & 0.65 & 0.33 \\
\hline 0.00 & 0.00 & 0.00 & 0.00 & 0.00 & 0.00 & 0.00 & 0.00 & 0.00 \\
\hline 0.00 & 0.00 & 0.00 & 0.00 & 0.00 & 0.00 & 0.00 & 0.00 & 0.00 \\
\hline 0.00 & 0.00 & 0.00 & 0.00 & 0.00 & 0.00 & 0.00 & 0.00 & 0.00 \\
\hline 0.00 & 0.00 & 0.33 & 0.32 & 0.33 & 0.33 & 0.00 & 0.00 & 0.00 \\
\hline 0.33 & 0.00 & 13.31 & 0.32 & 3.00 & 0.33 & 0.00 & 0.98 & 2.00 \\
\hline 0.00 & 0.00 & 0.00 & 0.00 & 0.00 & 0.00 & 0.00 & 0.00 & 0.00 \\
\hline 0.00 & 0.00 & 0.00 & 0.00 & 0.00 & 0.00 & 0.00 & 0.00 & 0.00 \\
\hline 0.00 & 0.00 & 0.00 & 0.00 & 0.00 & 0.00 & 0.00 & 0.00 & 0.00 \\
\hline 0.00 & 0.00 & 0.00 & 0.00 & 0.00 & 0.00 & 0.00 & 0.00 & 0.00 \\
\hline 0.00 & 0.00 & 0.00 & 0.00 & 0.00 & 0.00 & 0.00 & 0.00 & 0.00 \\
\hline 0.00 & 0.00 & 0.00 & 0.00 & 0.00 & 0.00 & 0.00 & 0.00 & 0.33 \\
\hline 0.67 & 3.97 & 1.66 & 2.24 & 3.33 & 3.33 & 3.31 & 1.95 & 5.00 \\
\hline 1.33 & 0.00 & 1.66 & 0.96 & 0.67 & 0.00 & 0.00 & 1.30 & 0.67 \\
\hline 0.00 & 0.00 & 0.33 & 0.00 & 0.00 & 0.00 & 0.00 & 0.00 & 0.00 \\
\hline
\end{tabular}




$\begin{array}{rrrrrrrrr}38.67 & 49.67 & 36.27 & 34.62 & 33.94 & 42.26 & 54.55 & 41.30 & 37.33 \\ 0.67 & 0.00 & 0.33 & 0.64 & 1.00 & 0.00 & 0.00 & 0.98 & 1.00 \\ 0.00 & 0.00 & 0.00 & 0.00 & 0.00 & 0.00 & 0.00 & 0.33 & 0.00 \\ 0.00 & 0.00 & 0.33 & 0.00 & 0.00 & 0.00 & 0.00 & 0.33 & 0.00 \\ 6.17 & 14.24 & 10.32 & 16.35 & 3.49 & 11.81 & 3.97 & 11.06 & 11.33 \\ 0.00 & 0.00 & 0.00 & 0.00 & 0.00 & 0.00 & 0.00 & 0.00 & 0.00 \\ 0.00 & 0.00 & 0.00 & 0.00 & 0.00 & 0.00 & 0.00 & 0.00 & 0.00 \\ 4.67 & 0.33 & 1.66 & 0.32 & 3.00 & 1.00 & 0.66 & 2.60 & 1.33 \\ 0.33 & 0.99 & 1.66 & 0.64 & 1.66 & 0.33 & 0.33 & 0.00 & 0.67 \\ 0.00 & 0.00 & 0.00 & 0.00 & 0.00 & 0.00 & 0.33 & 0.33 & 0.00 \\ 0.00 & 0.00 & 0.00 & 0.00 & 0.00 & 0.00 & 0.66 & 0.00 & 0.00 \\ 4.17 & 4.30 & 2.66 & 7.69 & 5.32 & 3.99 & 5.95 & 3.25 & 7.67 \\ 0.00 & 0.00 & 0.00 & 0.00 & 0.00 & 0.00 & 0.00 & 0.00 & 0.00 \\ 0.00 & 0.00 & 0.00 & 0.32 & 0.00 & 0.00 & 0.33 & 0.33 & 0.33\end{array}$




\begin{tabular}{|c|c|c|c|c|c|c|c|c|}
\hline $\begin{array}{r}38.11 \\
6297\end{array}$ & $\begin{array}{r}38.21 \\
6319\end{array}$ & $\begin{array}{r}38.52 \\
6390\end{array}$ & $\begin{array}{r}38.63 \\
6415\end{array}$ & $\begin{array}{r}38.71 \\
6433\end{array}$ & $\begin{array}{r}38.91 \\
6478\end{array}$ & $\begin{array}{r}39.11 \\
6523\end{array}$ & $\begin{array}{r}39.31 \\
6568\end{array}$ & $\begin{array}{r}39.51 \\
6614\end{array}$ \\
\hline 0.00 & 0.00 & 0.00 & 0.00 & 0.00 & 0.00 & 0.33 & 0.00 & 0.00 \\
\hline 0.00 & 0.33 & 0.33 & 0.00 & 0.33 & 0.99 & 0.00 & 0.00 & 0.00 \\
\hline 0.00 & 0.00 & 0.00 & 0.00 & 0.00 & 0.66 & 0.00 & 0.00 & 0.00 \\
\hline 0.00 & 0.00 & 0.00 & 0.66 & 0.00 & 0.00 & 0.33 & 0.00 & 0.00 \\
\hline 0.00 & 0.33 & 1.33 & 0.00 & 0.00 & 0.00 & 0.33 & 0.00 & 0.66 \\
\hline 0.00 & 0.00 & 0.00 & 0.00 & 0.00 & 0.00 & 0.00 & 0.00 & 0.00 \\
\hline 1.67 & 1.65 & 0.00 & 2.81 & 0.65 & 1.99 & 0.00 & 0.00 & 0.00 \\
\hline 0.00 & 0.33 & 0.00 & 0.33 & 0.00 & 0.00 & 0.00 & 0.00 & 0.00 \\
\hline 0.00 & 0.00 & 0.00 & 0.00 & 0.00 & 0.00 & 0.00 & 0.00 & 0.00 \\
\hline 0.83 & 1.81 & 1.99 & 1.49 & 1.15 & 2.98 & 1.16 & 1.65 & 2.31 \\
\hline 0.00 & 0.49 & 0.00 & 0.50 & 0.00 & 0.00 & 0.33 & 0.00 & 0.00 \\
\hline 0.00 & 0.00 & 0.00 & 0.00 & 0.00 & 0.00 & 0.33 & 0.00 & 0.66 \\
\hline 0.00 & 0.00 & 0.00 & 0.00 & 0.00 & 0.66 & 0.00 & 0.00 & 0.33 \\
\hline 0.00 & 0.00 & 0.00 & 0.33 & 0.33 & 0.99 & 0.00 & 0.00 & 0.00 \\
\hline 0.00 & 0.00 & 0.83 & 1.32 & 0.33 & 0.17 & 0.33 & 0.00 & 0.00 \\
\hline 0.00 & 0.00 & 0.00 & 0.00 & 0.00 & 0.00 & 0.00 & 0.00 & 0.00 \\
\hline 0.00 & 0.16 & 0.00 & 0.00 & 0.00 & 0.00 & 0.50 & 0.00 & 0.00 \\
\hline 3.00 & 1.32 & 2.99 & 3.48 & 2.13 & 2.48 & 1.66 & 1.81 & 0.99 \\
\hline 3.33 & 2.31 & 0.00 & 0.66 & 0.00 & 0.33 & 1.66 & 3.95 & 1.32 \\
\hline 0.67 & 0.66 & 0.00 & 0.00 & 0.00 & 0.17 & 0.00 & 0.00 & 0.66 \\
\hline 0.67 & 1.65 & 1.33 & 1.32 & 2.78 & 3.15 & 1.00 & 1.32 & 1.98 \\
\hline 0.00 & 0.00 & 0.00 & 0.99 & 0.33 & 0.33 & 0.00 & 0.00 & 0.00 \\
\hline 3.33 & 2.64 & 4.31 & 1.32 & 3.60 & 0.99 & 0.67 & 0.00 & 1.98 \\
\hline 0.17 & 0.00 & 0.00 & 0.00 & 0.00 & 0.00 & 0.00 & 0.00 & 0.99 \\
\hline 0.33 & 0.00 & 0.00 & 0.66 & 0.65 & 0.00 & 0.00 & 0.00 & 0.33 \\
\hline 0.67 & 0.16 & 0.33 & 0.17 & 0.33 & 0.83 & 1.16 & 1.15 & 1.32 \\
\hline 1.33 & 0.00 & 0.33 & 0.00 & 0.00 & 0.66 & 0.00 & 0.00 & 0.00 \\
\hline 0.67 & 0.82 & 0.33 & 2.32 & 3.44 & 0.33 & 1.00 & 0.33 & 0.83 \\
\hline 9.50 & 5.60 & 7.30 & 12.91 & 6.55 & 13.41 & 8.32 & 10.87 & 9.41 \\
\hline 3.00 & 5.27 & 2.32 & 3.31 & 2.62 & 3.97 & 10.65 & 3.95 & 5.28 \\
\hline 0.00 & 0.00 & 0.00 & 0.00 & 0.33 & 0.00 & 0.33 & 0.00 & 0.00 \\
\hline 0.33 & 0.82 & 1.16 & 0.33 & 0.49 & 1.16 & 0.33 & 0.82 & 0.17 \\
\hline 0.00 & 0.66 & 0.33 & 0.00 & 0.98 & 0.99 & 0.00 & 0.66 & 0.00 \\
\hline 0.00 & 0.66 & 0.83 & 0.66 & 1.80 & 0.50 & 0.17 & 0.66 & 0.66 \\
\hline 0.00 & 0.00 & 0.00 & 0.00 & 0.00 & 0.00 & 0.00 & 0.00 & 0.00 \\
\hline 0.00 & 0.66 & 0.00 & 0.00 & 0.00 & 0.00 & 0.00 & 0.66 & 0.00 \\
\hline 0.00 & 0.00 & 0.00 & 0.00 & 0.00 & 0.00 & 0.00 & 0.00 & 0.00 \\
\hline 0.33 & 0.00 & 0.00 & 0.00 & 0.00 & 0.00 & 0.00 & 0.00 & 0.00 \\
\hline 1.67 & 0.99 & 1.66 & 2.65 & 0.33 & 3.97 & 2.00 & 0.66 & 1.98 \\
\hline 0.00 & 0.00 & 0.00 & 0.00 & 0.00 & 0.00 & 0.00 & 0.00 & 0.00 \\
\hline 0.00 & 0.00 & 0.00 & 0.00 & 0.00 & 0.33 & 0.00 & 0.00 & 0.00 \\
\hline 0.00 & 0.00 & 0.00 & 0.00 & 0.00 & 0.00 & 0.00 & 0.00 & 0.00 \\
\hline 0.00 & 0.00 & 0.00 & 0.00 & 0.00 & 0.00 & 0.00 & 0.00 & 0.00 \\
\hline 0.00 & 0.00 & 0.00 & 0.00 & 0.00 & 0.00 & 0.00 & 0.33 & 0.00 \\
\hline 0.00 & 0.00 & 0.00 & 0.00 & 0.00 & 0.00 & 0.00 & 0.00 & 0.00 \\
\hline 3.33 & 2.31 & 3.32 & 4.30 & 3.60 & 2.98 & 4.99 & 1.65 & 2.31 \\
\hline 0.00 & 0.99 & 1.00 & 0.00 & 0.00 & 0.00 & 3.99 & 0.00 & 0.99 \\
\hline 0.00 & 0.00 & 0.00 & 0.00 & 0.00 & 0.00 & 0.33 & 0.00 & 0.00 \\
\hline
\end{tabular}




$\begin{array}{rrrrrrrrr}39.00 & 42.17 & 45.44 & 35.76 & 41.90 & 22.52 & 29.62 & 46.79 & 29.37 \\ 1.00 & 0.99 & 0.00 & 0.00 & 0.00 & 1.32 & 0.33 & 0.00 & 1.32 \\ 0.00 & 0.00 & 0.00 & 0.00 & 0.00 & 0.66 & 0.67 & 0.33 & 0.33 \\ 0.00 & 0.33 & 0.00 & 0.00 & 0.33 & 0.99 & 0.00 & 0.00 & 0.00 \\ 7.17 & 3.95 & 5.97 & 2.32 & 6.38 & 3.81 & 2.50 & 6.75 & 6.60 \\ 0.33 & 0.00 & 0.00 & 0.00 & 0.00 & 0.00 & 0.00 & 0.00 & 0.00 \\ 0.33 & 0.00 & 0.00 & 0.00 & 0.00 & 0.00 & 0.00 & 0.00 & 0.00 \\ 1.67 & 1.65 & 1.66 & 1.99 & 1.64 & 2.98 & 1.33 & 0.66 & 2.31 \\ 1.33 & 0.66 & 0.66 & 1.66 & 0.00 & 1.99 & 1.66 & 0.99 & 0.66 \\ 0.00 & 3.95 & 0.00 & 0.00 & 0.00 & 0.33 & 0.00 & 0.33 & 0.00 \\ 0.00 & 0.00 & 0.00 & 0.66 & 0.00 & 0.33 & 1.00 & 0.00 & 0.00 \\ 4.67 & 6.26 & 2.32 & 3.97 & 7.20 & 3.31 & 7.32 & 3.62 & 13.20 \\ 0.00 & 0.00 & 0.00 & 0.00 & 0.00 & 0.00 & 0.00 & 0.00 & 0.00 \\ 0.00 & 0.00 & 0.00 & 0.00 & 0.33 & 0.00 & 0.00 & 0.00 & 0.00\end{array}$




\begin{tabular}{|c|c|c|c|c|c|c|c|c|}
\hline $\begin{array}{r}39.71 \\
6659\end{array}$ & $\begin{array}{r}39.91 \\
6682\end{array}$ & $\begin{array}{r}40.11 \\
6699\end{array}$ & $\begin{array}{r}40.31 \\
6717\end{array}$ & $\begin{array}{r}40.51 \\
6734\end{array}$ & $\begin{array}{r}40.71 \\
6751\end{array}$ & $\begin{array}{r}40.91 \\
6768\end{array}$ & $\begin{array}{r}41.13 \\
6787\end{array}$ & $\begin{array}{r}41.26 \\
6799\end{array}$ \\
\hline 0.00 & 0.00 & 0.00 & 0.00 & 0.00 & 0.00 & 0.00 & 0.00 & 0.00 \\
\hline 0.66 & 0.33 & 0.81 & 0.00 & 0.17 & 0.00 & 0.00 & 0.00 & 0.66 \\
\hline 0.00 & 0.00 & 0.00 & 0.00 & 0.00 & 0.00 & 0.00 & 0.00 & 0.00 \\
\hline 0.00 & 0.00 & 0.65 & 0.33 & 0.99 & 0.00 & 0.00 & 0.00 & 0.00 \\
\hline 0.66 & 0.00 & 0.00 & 0.66 & 0.99 & 1.98 & 0.00 & 0.00 & 1.32 \\
\hline 0.00 & 0.00 & 0.00 & 0.00 & 0.00 & 0.00 & 0.00 & 0.00 & 0.00 \\
\hline 0.33 & 0.00 & 1.29 & 1.99 & 0.99 & 0.33 & 0.00 & 0.00 & 1.32 \\
\hline 0.00 & 0.00 & 0.00 & 0.00 & 0.00 & 0.00 & 0.00 & 0.00 & 0.00 \\
\hline 0.00 & 0.00 & 0.00 & 0.00 & 0.00 & 0.00 & 0.00 & 0.00 & 0.00 \\
\hline 1.65 & 2.67 & 1.45 & 0.66 & 0.66 & 1.32 & 0.67 & 2.25 & 1.16 \\
\hline 0.00 & 0.00 & 0.32 & 0.00 & 0.00 & 0.00 & 0.00 & 0.00 & 0.00 \\
\hline 0.00 & 0.00 & 0.00 & 0.00 & 0.00 & 0.00 & 0.00 & 0.00 & 0.00 \\
\hline 0.00 & 0.00 & 0.00 & 0.00 & 0.00 & 0.00 & 0.67 & 0.00 & 0.00 \\
\hline 0.00 & 0.00 & 0.97 & 0.00 & 0.33 & 0.00 & 0.00 & 0.97 & 0.33 \\
\hline 0.00 & 3.33 & 0.00 & 0.00 & 1.65 & 1.49 & 0.33 & 0.00 & 0.99 \\
\hline 0.00 & 0.00 & 0.00 & 0.00 & 0.00 & 0.00 & 0.00 & 0.00 & 0.00 \\
\hline 0.00 & 0.00 & 0.00 & 0.00 & 0.00 & 0.00 & 0.00 & 0.00 & 0.00 \\
\hline 1.98 & 1.67 & 0.81 & 0.99 & 0.66 & 0.99 & 1.17 & 0.97 & 1.16 \\
\hline 2.64 & 0.67 & 1.94 & 3.64 & 5.95 & 0.33 & 3.00 & 0.00 & 2.31 \\
\hline 0.33 & 0.83 & 0.00 & 0.00 & 0.17 & 0.50 & 0.17 & 0.00 & 0.50 \\
\hline 0.49 & 0.33 & 0.65 & 0.83 & 3.80 & 2.97 & 1.00 & 1.77 & 1.65 \\
\hline 0.33 & 0.33 & 0.00 & 0.00 & 0.00 & 0.00 & 0.00 & 0.32 & 0.33 \\
\hline 1.32 & 1.67 & 0.00 & 0.00 & 0.33 & 1.65 & 0.33 & 0.64 & 0.33 \\
\hline 0.00 & 0.00 & 0.00 & 0.00 & 0.00 & 0.00 & 0.00 & 0.16 & 0.00 \\
\hline 0.99 & 0.17 & 0.81 & 0.00 & 0.99 & 0.17 & 0.00 & 0.32 & 0.00 \\
\hline 0.33 & 0.17 & 0.97 & 0.66 & 0.17 & 0.17 & 0.67 & 0.64 & 1.32 \\
\hline 0.33 & 0.33 & 0.00 & 0.00 & 0.00 & 1.32 & 0.67 & 0.00 & 0.50 \\
\hline 0.82 & 0.50 & 1.13 & 0.33 & 1.32 & 0.83 & 1.67 & 0.48 & 1.16 \\
\hline 13.51 & 15.17 & 13.41 & 9.11 & 8.76 & 7.43 & 5.00 & 11.43 & 7.43 \\
\hline 4.28 & 3.67 & 3.88 & 1.99 & 1.65 & 2.97 & 4.67 & 3.22 & 4.29 \\
\hline 0.00 & 0.00 & 0.32 & 0.00 & 0.00 & 0.00 & 0.33 & 0.32 & 0.17 \\
\hline 0.82 & 1.00 & 0.32 & 0.66 & 0.33 & 0.66 & 0.50 & 0.64 & 0.33 \\
\hline 0.33 & 0.67 & 0.97 & 0.17 & 0.66 & 0.66 & 1.00 & 0.32 & 1.82 \\
\hline 0.49 & 1.33 & 0.48 & 0.66 & 1.16 & 1.32 & 0.50 & 1.61 & 1.49 \\
\hline 0.00 & 0.00 & 0.00 & 0.00 & 0.00 & 0.00 & 0.00 & 0.00 & 0.0 \\
\hline 0.00 & 0.00 & 0.00 & 0.00 & 0.00 & 0.00 & 0.33 & 0.00 & 0.00 \\
\hline 0.00 & 0.00 & 0.00 & 0.00 & 0.00 & 0.33 & 0.00 & 0.00 & 0.00 \\
\hline 0.33 & 0.00 & 0.32 & 0.00 & 0.33 & 0.00 & 0.33 & 0.00 & 0.00 \\
\hline 1.98 & 1.33 & 1.29 & 4.97 & 2.31 & 0.33 & 4.00 & 13.85 & 3.63 \\
\hline 0.00 & 0.00 & 0.00 & 0.00 & 0.00 & 0.00 & 0.00 & 0.00 & 0.00 \\
\hline 0.00 & 0.00 & 0.00 & 0.00 & 0.00 & 0.00 & 0.00 & 0.00 & 0.00 \\
\hline 0.00 & 0.00 & 0.00 & 0.00 & 0.00 & 0.00 & 0.00 & 0.00 & 0.00 \\
\hline 0.00 & 0.00 & 0.00 & 0.00 & 0.00 & 0.00 & 0.00 & 0.00 & 0.00 \\
\hline 0.00 & 0.00 & 0.00 & 0.00 & 0.33 & 0.00 & 0.00 & 0.00 & 0.00 \\
\hline 0.00 & 0.00 & 0.32 & 0.00 & 0.00 & 0.00 & 0.00 & 0.00 & 0.33 \\
\hline 1.98 & 3.33 & 2.26 & 2.65 & 2.31 & 3.63 & 1.67 & 0.64 & 4.29 \\
\hline 0.66 & 0.00 & 1.29 & 2.32 & 1.32 & 0.99 & 0.33 & 4.83 & 1.32 \\
\hline 0.00 & 0.00 & 0.00 & 0.00 & 0.00 & 0.00 & 0.00 & 0.00 & 0.0 \\
\hline
\end{tabular}




$\begin{array}{rrrrrrrrr}29.65 & 34.67 & 35.22 & 41.06 & 39.01 & 41.58 & 39.67 & 30.27 & 31.35 \\ 0.00 & 0.00 & 0.65 & 0.33 & 0.00 & 0.00 & 0.00 & 0.32 & 0.66 \\ 0.66 & 0.33 & 0.00 & 0.00 & 0.00 & 0.00 & 0.00 & 0.32 & 0.33 \\ 0.00 & 0.67 & 0.32 & 0.00 & 0.33 & 0.00 & 0.00 & 0.32 & 1.98 \\ 9.39 & 8.83 & 6.79 & 8.11 & 8.26 & 8.58 & 5.67 & 10.31 & 7.43 \\ 0.00 & 0.00 & 0.00 & 0.00 & 0.00 & 0.00 & 0.00 & 0.00 & 0.00 \\ 0.00 & 0.00 & 0.65 & 0.00 & 0.00 & 0.00 & 0.33 & 0.00 & 0.33 \\ 3.62 & 0.67 & 1.62 & 1.66 & 0.33 & 0.99 & 1.33 & 0.32 & 0.66 \\ 0.99 & 1.33 & 0.97 & 1.32 & 1.65 & 1.32 & 1.00 & 0.00 & 1.32 \\ 0.33 & 0.00 & 0.32 & 0.33 & 1.65 & 0.33 & 0.00 & 0.00 & 0.00 \\ 0.00 & 0.33 & 0.00 & 0.00 & 0.00 & 0.00 & 0.67 & 0.00 & 0.33 \\ 5.27 & 3.33 & 5.82 & 5.30 & 6.61 & 6.60 & 10.00 & 5.80 & 5.94 \\ 0.00 & 0.00 & 0.00 & 0.00 & 0.00 & 0.00 & 0.00 & 0.00 & 0.00 \\ 0.33 & 0.33 & 0.00 & 0.00 & 0.00 & 0.00 & 0.00 & 0.00 & 0.00\end{array}$




\begin{tabular}{|c|c|c|c|c|c|c|c|c|}
\hline 41.6 & 41.76 & 41.8 & 41.96 & 42.03 & 42.165 & 42.24 & 42.36 & 42.56 \\
\hline 6828 & 6842 & 6845 & 6859 & 6865 & 6877 & 6883 & 6894 & 6911 \\
\hline 0.00 & 0.00 & 0.00 & 0.00 & 0.33 & 1.63 & 0.95 & 0.64 & 0.00 \\
\hline 0.00 & 0.67 & 0.00 & 0.00 & 0.33 & 0.65 & 0.32 & 1.28 & 0.00 \\
\hline 0.00 & 0.00 & 0.00 & 0.00 & 0.00 & 0.00 & 0.00 & 1.28 & 0.00 \\
\hline 0.00 & 0.00 & 0.00 & 0.00 & 0.00 & 0.00 & 0.00 & 0.00 & 0.00 \\
\hline 0.00 & 0.00 & 0.00 & 0.00 & 0.66 & 0.00 & 0.32 & 0.00 & 0.00 \\
\hline 0.33 & 0.00 & 0.00 & 0.00 & 0.00 & 0.00 & 0.00 & 0.00 & 0.00 \\
\hline 0.00 & 0.00 & 0.00 & 0.67 & 0.99 & 2.12 & 0.95 & 0.00 & 0.32 \\
\hline 0.00 & 0.00 & 0.00 & 0.00 & 0.00 & 0.00 & 0.32 & 0.00 & 0.00 \\
\hline 0.00 & 0.00 & 0.00 & 0.00 & 0.00 & 0.00 & 0.00 & 0.00 & 0.00 \\
\hline 0.33 & 1.50 & 0.63 & 1.00 & 1.32 & 1.63 & 0.79 & 0.80 & 0.32 \\
\hline 0.00 & 0.00 & 0.00 & 0.00 & 0.00 & 0.00 & 0.16 & 0.32 & 0.00 \\
\hline 0.00 & 0.00 & 0.00 & 0.00 & 0.00 & 0.00 & 0.00 & 0.00 & 0.00 \\
\hline 0.00 & 0.00 & 0.00 & 0.00 & 0.00 & 0.00 & 0.00 & 0.00 & 0.00 \\
\hline 0.00 & 0.00 & 0.00 & 0.00 & 0.66 & 0.33 & 0.63 & 0.00 & 0.00 \\
\hline 1.00 & 0.00 & 0.00 & 0.67 & 0.00 & 0.98 & 2.86 & 0.00 & 0.97 \\
\hline 0.00 & 0.00 & 0.00 & 0.00 & 0.00 & 0.00 & 0.00 & 0.96 & 0.00 \\
\hline 0.00 & 0.00 & 0.00 & 1.00 & 0.00 & 0.00 & 0.00 & 0.32 & 0.00 \\
\hline 0.00 & 0.50 & 1.11 & 1.17 & 0.83 & 1.31 & 0.95 & 0.64 & 0.48 \\
\hline 0.33 & 1.33 & 0.63 & 0.00 & 1.32 & 2.61 & 1.27 & 0.00 & 0.65 \\
\hline 0.17 & 0.00 & 0.32 & 0.00 & 0.66 & 0.00 & 0.63 & 0.00 & 0.00 \\
\hline 2.33 & 1.00 & 1.58 & 0.33 & 0.99 & 4.73 & 2.70 & 0.32 & 0.65 \\
\hline 0.00 & 0.33 & 0.00 & 0.67 & 0.00 & 0.33 & 0.00 & 0.00 & 0.00 \\
\hline 0.00 & 0.67 & 0.63 & 0.00 & 1.98 & 1.31 & 0.63 & 0.00 & 0.65 \\
\hline 0.33 & 0.17 & 0.00 & 0.00 & 0.00 & 0.00 & 0.16 & 0.00 & 0.16 \\
\hline 0.50 & 0.67 & 0.00 & 0.33 & 1.16 & 0.00 & 0.16 & 0.00 & 0.32 \\
\hline 0.67 & 0.50 & 0.32 & 0.00 & 0.99 & 0.65 & 0.32 & 0.32 & 0.97 \\
\hline 0.00 & 0.00 & 0.00 & 0.00 & 0.00 & 0.33 & 0.00 & 0.00 & 0.65 \\
\hline 0.17 & 0.00 & 0.63 & 0.50 & 1.16 & 0.00 & 0.16 & 0.96 & 0.65 \\
\hline 9.50 & 5.50 & 5.06 & 7.33 & 5.29 & 6.69 & 7.30 & 7.67 & 3.87 \\
\hline 7.00 & 7.67 & 1.58 & 3.00 & 3.97 & 2.94 & 2.86 & 2.72 & 3.23 \\
\hline 0.33 & 0.00 & 0.00 & 0.00 & 0.00 & 0.00 & 0.00 & 0.00 & 0.00 \\
\hline 0.00 & 0.33 & 0.32 & 0.17 & 0.33 & 0.00 & 0.32 & 0.00 & 0.32 \\
\hline 1.17 & 0.33 & 0.95 & 1.17 & 0.00 & 0.82 & 0.32 & 0.00 & 0.32 \\
\hline 0.50 & 0.83 & 0.79 & 1.00 & 0.33 & 0.33 & 0.63 & 0.48 & 0.00 \\
\hline 0.00 & 0.00 & 0.00 & 0.00 & 0.00 & 0.00 & 0.00 & 0.00 & 0.00 \\
\hline 0.00 & 0.00 & 0.63 & 0.00 & 0.00 & 0.00 & 0.00 & 0.00 & 0.00 \\
\hline 0.00 & 0.00 & 0.00 & 0.00 & 0.00 & 0.00 & 0.00 & 0.00 & 0.00 \\
\hline 0.00 & 0.33 & 0.00 & 0.00 & 0.00 & 0.00 & 0.00 & 0.00 & 0.00 \\
\hline 4.00 & 3.67 & 5.38 & 3.00 & 0.99 & 3.59 & 1.27 & 1.60 & 6.13 \\
\hline 0.00 & 0.00 & 0.00 & 0.00 & 0.00 & 0.00 & 0.00 & 0.00 & 0.00 \\
\hline 0.00 & 0.00 & 0.00 & 0.00 & 0.00 & 0.00 & 0.00 & 0.00 & 0.00 \\
\hline 0.00 & 0.33 & 0.00 & 0.00 & 0.00 & 0.00 & 0.32 & 0.00 & 0.00 \\
\hline 0.00 & 0.00 & 0.00 & 0.00 & 0.00 & 0.00 & 0.00 & 0.00 & 0.00 \\
\hline 0.00 & 0.00 & 0.00 & 0.00 & 0.00 & 0.00 & 0.00 & 0.00 & 0.00 \\
\hline 0.00 & 0.00 & 0.32 & 0.00 & 0.00 & 0.00 & 0.00 & 0.00 & 0.00 \\
\hline 0.67 & 2.00 & 0.95 & 0.00 & 0.99 & 0.98 & 1.27 & 1.60 & 1.61 \\
\hline 1.33 & 0.67 & 0.63 & 0.67 & 0.00 & 1.63 & 1.27 & 0.00 & 0.00 \\
\hline 0.00 & 0.00 & 0.00 & 0.00 & 0.00 & 0.00 & 0.00 & 0.00 & 0.00 \\
\hline
\end{tabular}




$\begin{array}{rrrrrrrrr}40.00 & 42.33 & 46.20 & 41.00 & 41.98 & 34.91 & 37.14 & 46.33 & 37.42 \\ 0.00 & 0.33 & 0.00 & 0.33 & 0.00 & 0.00 & 0.63 & 0.00 & 0.00 \\ 0.00 & 0.00 & 0.00 & 0.00 & 0.00 & 0.33 & 0.00 & 0.00 & 0.00 \\ 0.00 & 0.00 & 0.00 & 0.33 & 0.66 & 1.31 & 0.95 & 0.00 & 0.97 \\ 12.00 & 11.17 & 14.24 & 9.17 & 17.52 & 8.32 & 12.70 & 19.49 & 11.94 \\ 0.00 & 0.33 & 0.00 & 0.00 & 0.00 & 0.00 & 0.00 & 0.00 & 0.00 \\ 0.00 & 0.00 & 0.00 & 0.00 & 0.00 & 0.00 & 0.63 & 0.00 & 0.00 \\ 1.67 & 1.00 & 1.90 & 1.67 & 0.33 & 3.59 & 1.59 & 0.96 & 5.81 \\ 3.00 & 0.33 & 0.00 & 1.00 & 1.32 & 1.31 & 1.90 & 0.32 & 9.68 \\ 0.00 & 0.33 & 0.95 & 0.00 & 0.00 & 0.00 & 0.00 & 0.00 & 0.00 \\ 0.00 & 1.33 & 0.32 & 0.00 & 0.33 & 0.33 & 0.00 & 0.00 & 0.00 \\ 6.67 & 7.00 & 6.01 & 15.00 & 5.62 & 2.61 & 6.03 & 1.28 & 3.87 \\ 0.00 & 0.00 & 0.00 & 0.00 & 0.00 & 0.00 & 0.00 & 0.00 & 0.00 \\ 0.00 & 0.00 & 0.00 & 0.00 & 0.00 & 0.00 & 0.00 & 0.00 & 0.00\end{array}$




\begin{tabular}{|c|c|c|c|c|c|c|c|c|}
\hline 42.76 & 42.96 & 43.16 & 43.36 & 43.56 & 43.76 & 43.88 & 43.96 & $\begin{array}{r}44.16 \\
7050\end{array}$ \\
\hline 6928 & 6946 & 6963 & 6980 & 6998 & 7015 & 7025 & 7032 & 7050 \\
\hline 0.00 & 0.00 & 0.32 & 0.00 & 0.32 & 0.00 & 0.00 & 0.32 & 0.00 \\
\hline 0.48 & 0.00 & 0.00 & 0.00 & 0.32 & 0.81 & 0.33 & 0.00 & 0.99 \\
\hline 0.00 & 0.00 & 0.00 & 0.00 & 0.00 & 0.00 & 0.00 & 0.00 & 0.00 \\
\hline 0.00 & 0.00 & 0.00 & 0.00 & 0.00 & 0.32 & 0.65 & 0.32 & 0.66 \\
\hline 0.00 & 0.00 & 0.00 & 0.00 & 0.32 & 0.97 & 0.00 & 0.00 & 0.00 \\
\hline 0.00 & 0.00 & 0.00 & 0.00 & 0.00 & 0.00 & 0.00 & 0.00 & 0.00 \\
\hline 0.97 & 1.27 & 0.32 & 0.65 & 0.96 & 0.32 & 0.00 & 0.32 & 0.00 \\
\hline 0.00 & 0.00 & 0.00 & 0.33 & 0.00 & 0.32 & 0.33 & 0.32 & 0.33 \\
\hline 0.00 & 0.00 & 0.00 & 0.00 & 0.00 & 0.00 & 0.00 & 0.00 & 0.00 \\
\hline 1.29 & 0.95 & 2.27 & 1.15 & 0.16 & 0.32 & 1.31 & 2.25 & 1.82 \\
\hline 0.00 & 0.00 & 0.00 & 0.00 & 0.00 & 0.48 & 0.00 & 0.16 & 0.00 \\
\hline 0.00 & 0.00 & 0.00 & 0.00 & 0.00 & 0.00 & 0.00 & 0.00 & 0.00 \\
\hline 0.00 & 0.00 & 0.00 & 0.00 & 0.32 & 0.00 & 0.00 & 0.00 & 0.00 \\
\hline 0.00 & 0.00 & 0.00 & 0.33 & 0.96 & 0.00 & 0.00 & 0.32 & 0.33 \\
\hline 0.00 & 1.58 & 0.97 & 0.00 & 0.32 & 0.00 & 1.31 & 0.00 & 0.66 \\
\hline 0.00 & 0.00 & 0.00 & 0.00 & 0.00 & 0.16 & 0.00 & 0.00 & 0.00 \\
\hline 0.32 & 0.00 & 0.00 & 0.33 & 0.00 & 0.00 & 0.00 & 0.00 & 0.00 \\
\hline 1.78 & 0.79 & 0.32 & 0.65 & 0.48 & 0.48 & 1.31 & 1.44 & 0.50 \\
\hline 0.00 & 0.32 & 0.65 & 1.64 & 1.60 & 2.58 & 2.29 & 0.32 & 1.65 \\
\hline 0.00 & 0.16 & 0.16 & 0.16 & 0.00 & 0.00 & 0.16 & 0.00 & 0.00 \\
\hline 1.94 & 1.58 & 0.97 & 2.78 & 1.60 & 0.64 & 1.47 & 1.44 & 4.13 \\
\hline 0.00 & 0.32 & 0.00 & 0.00 & 0.32 & 0.00 & 0.00 & 0.00 & 0.00 \\
\hline 0.97 & 0.32 & 0.32 & 1.64 & 0.00 & 0.00 & 1.31 & 0.00 & 0.00 \\
\hline 0.00 & 0.00 & 0.00 & 0.00 & 0.32 & 0.00 & 0.00 & 0.00 & 0.00 \\
\hline 0.65 & 0.32 & 0.00 & 0.16 & 0.80 & 0.00 & 0.00 & 0.00 & 0.33 \\
\hline 0.81 & 1.58 & 0.16 & 0.33 & 1.92 & 0.16 & 0.65 & 0.00 & 0.17 \\
\hline 0.00 & 0.32 & 0.00 & 0.33 & 0.32 & 0.00 & 0.65 & 0.00 & 0.00 \\
\hline 0.32 & 1.27 & 0.32 & 0.82 & 0.32 & 0.48 & 0.16 & 0.48 & 0.17 \\
\hline 7.59 & 4.75 & 6.16 & 8.84 & 4.16 & 5.96 & 9.48 & 5.14 & 4.46 \\
\hline 3.55 & 4.43 & 7.46 & 3.93 & 2.88 & 3.54 & 1.63 & 7.38 & 3.30 \\
\hline 0.00 & 0.00 & 0.00 & 0.00 & 0.32 & 0.32 & 0.00 & 0.00 & 0.00 \\
\hline 0.00 & 0.95 & 0.97 & 0.49 & 1.12 & 0.16 & 0.00 & 0.64 & 0.00 \\
\hline 0.97 & 0.32 & 0.00 & 0.98 & 0.32 & 0.97 & 1.96 & 0.00 & 0.33 \\
\hline 1.62 & 0.79 & 0.97 & 0.98 & 0.64 & 0.32 & 0.98 & 0.80 & 0.66 \\
\hline 0.00 & 0.00 & 0.00 & 0.00 & 0.00 & 0.00 & 0.00 & 0.00 & 0.00 \\
\hline 0.00 & 0.00 & 0.00 & 0.00 & 0.00 & 0.00 & 0.00 & 0.00 & 0.00 \\
\hline 0.00 & 0.00 & 0.32 & 0.00 & 0.32 & 0.00 & 0.00 & 0.00 & 0.00 \\
\hline 0.32 & 0.00 & 0.00 & 0.00 & 0.32 & 0.00 & 0.00 & 0.00 & 0.00 \\
\hline 0.97 & 1.90 & 0.97 & 2.62 & 3.20 & 2.25 & 1.63 & 1.61 & 0.99 \\
\hline 0.00 & 0.00 & 0.00 & 0.00 & 0.00 & 0.00 & 0.00 & 0.00 & 0.00 \\
\hline 0.00 & 0.00 & 0.00 & 0.65 & 0.00 & 0.00 & 0.00 & 0.00 & 0.00 \\
\hline 0.65 & 0.00 & 0.00 & 0.00 & 0.00 & 0.00 & 0.00 & 0.00 & 0.00 \\
\hline 0.00 & 0.00 & 0.00 & 0.00 & 0.00 & 0.00 & 0.00 & 0.00 & 0.00 \\
\hline 0.00 & 0.32 & 0.00 & 0.00 & 0.00 & 0.32 & 0.00 & 0.00 & 0.33 \\
\hline 0.00 & 0.00 & 0.00 & 0.00 & 0.00 & 0.00 & 0.00 & 0.00 & 0.00 \\
\hline 0.32 & 0.95 & 0.32 & 0.98 & 0.00 & 0.64 & 0.98 & 0.96 & 2.64 \\
\hline 0.97 & 0.95 & 0.65 & 0.00 & 1.92 & 1.61 & 0.65 & 0.64 & 0.66 \\
\hline 0.00 & 0.00 & 0.00 & 0.00 & 0.00 & 0.00 & 0.00 & 0.00 & 0.00 \\
\hline
\end{tabular}




$\begin{array}{rrrrrrrrr}46.53 & 41.46 & 49.92 & 41.90 & 45.12 & 59.90 & 41.83 & 58.43 & 46.86 \\ 0.00 & 1.90 & 0.65 & 0.00 & 1.60 & 0.00 & 0.00 & 0.00 & 2.97 \\ 0.00 & 0.32 & 0.00 & 0.65 & 0.00 & 0.32 & 0.33 & 0.00 & 0.00 \\ 0.00 & 0.95 & 0.32 & 0.98 & 0.00 & 0.00 & 0.00 & 0.00 & 0.33 \\ 9.85 & 18.35 & 14.42 & 9.66 & 9.44 & 2.25 & 18.30 & 2.41 & 5.78 \\ 0.00 & 0.00 & 0.00 & 0.00 & 0.00 & 0.64 & 0.00 & 0.00 & 0.00 \\ 0.00 & 0.00 & 0.32 & 0.00 & 0.00 & 0.00 & 0.00 & 0.00 & 0.00 \\ 0.32 & 0.95 & 1.62 & 1.64 & 1.28 & 0.97 & 0.33 & 2.25 & 2.31 \\ 1.94 & 1.27 & 2.59 & 0.00 & 0.64 & 0.64 & 0.65 & 0.96 & 0.99 \\ 0.00 & 0.00 & 0.00 & 0.00 & 1.28 & 0.00 & 0.00 & 0.00 & 0.00 \\ 0.00 & 0.95 & 0.00 & 0.00 & 0.00 & 0.00 & 0.00 & 0.00 & 0.66 \\ 9.37 & 2.53 & 1.62 & 2.95 & 4.48 & 5.15 & 3.59 & 4.17 & 7.26 \\ 0.00 & 0.00 & 0.00 & 0.00 & 0.00 & 0.00 & 0.00 & 0.00 & 0.00 \\ 0.32 & 0.32 & 0.65 & 0.33 & 0.00 & 0.00 & 0.00 & 0.00 & 0.00\end{array}$




\begin{tabular}{|c|c|c|c|c|c|c|c|c|}
\hline 44.36 & 44.56 & 44.63 & 44.83 & 45.02 & 45.23 & 45.47 & 45.67 & $\begin{array}{r}45.87 \\
7198\end{array}$ \\
\hline 7067 & 7084 & 7090 & 7108 & 7124 & 7142 & 7163 & 7180 & 7198 \\
\hline 0.00 & 0.00 & 0.00 & 0.00 & 0.00 & 0.00 & 0.00 & 0.33 & 0.00 \\
\hline 0.67 & 0.00 & 0.31 & 0.00 & 0.00 & 0.00 & 0.00 & 0.33 & 0.00 \\
\hline 0.00 & 0.33 & 0.00 & 0.00 & 0.00 & 0.00 & 0.00 & 0.67 & 0.00 \\
\hline 0.00 & 0.00 & 0.00 & 0.00 & 0.00 & 0.00 & 0.33 & 0.33 & 0.00 \\
\hline 0.00 & 0.00 & 0.00 & 0.00 & 0.00 & 0.00 & 0.00 & 0.00 & 0.00 \\
\hline 0.00 & 0.00 & 0.00 & 0.00 & 0.00 & 0.00 & 0.00 & 0.00 & 0.00 \\
\hline 0.33 & 0.00 & 0.31 & 0.33 & 0.00 & 0.00 & 0.83 & 0.00 & 0.00 \\
\hline 0.00 & 0.00 & 0.15 & 0.00 & 0.66 & 0.17 & 0.00 & 0.17 & 0.33 \\
\hline 0.00 & 0.00 & 0.00 & 0.00 & 0.00 & 0.00 & 0.00 & 0.00 & 0.00 \\
\hline 0.17 & 1.16 & 0.61 & 1.82 & 0.66 & 1.83 & 1.17 & 1.00 & 1.33 \\
\hline 0.17 & 0.00 & 0.00 & 0.00 & 0.17 & 0.00 & 0.83 & 0.33 & 1.17 \\
\hline 0.00 & 0.00 & 0.00 & 0.00 & 0.00 & 0.00 & 0.00 & 0.00 & 0.00 \\
\hline 0.00 & 0.00 & 0.00 & 0.00 & 0.00 & 0.00 & 0.00 & 0.00 & 0.00 \\
\hline 0.00 & 0.00 & 0.61 & 0.00 & 0.00 & 0.00 & 0.67 & 0.00 & 0.00 \\
\hline 0.33 & 0.99 & 0.31 & 1.33 & 0.00 & 1.33 & 0.00 & 0.00 & 0.00 \\
\hline 0.00 & 0.00 & 0.00 & 0.00 & 0.00 & 0.00 & 0.00 & 0.50 & 0.00 \\
\hline 0.00 & 0.00 & 0.00 & 0.00 & 0.00 & 0.00 & 0.00 & 0.00 & 0.00 \\
\hline 0.33 & 0.50 & 0.76 & 0.33 & 1.99 & 1.33 & 1.67 & 1.00 & 4.50 \\
\hline 0.33 & 0.00 & 1.22 & 0.33 & 0.99 & 1.33 & 4.00 & 2.33 & 0.67 \\
\hline 0.67 & 0.00 & 0.31 & 0.00 & 0.33 & 0.83 & 0.00 & 0.00 & 0.67 \\
\hline 1.17 & 3.64 & 3.06 & 1.33 & 1.66 & 0.67 & 0.00 & 1.00 & 0.00 \\
\hline 0.00 & 0.66 & 0.00 & 0.00 & 0.33 & 0.00 & 0.00 & 0.00 & 0.00 \\
\hline 0.67 & 1.99 & 3.36 & 0.00 & 0.00 & 0.00 & 0.00 & 0.00 & 0.00 \\
\hline 0.00 & 0.00 & 0.00 & 0.00 & 0.00 & 0.17 & 0.00 & 0.00 & 0.00 \\
\hline 0.17 & 0.00 & 0.31 & 0.00 & 0.33 & 0.00 & 0.00 & 0.00 & 0.00 \\
\hline 0.67 & 0.66 & 0.15 & 0.17 & 0.00 & 0.67 & 1.00 & 0.00 & 0.50 \\
\hline 0.33 & 0.00 & 0.61 & 0.66 & 0.33 & 0.50 & 0.00 & 0.00 & 0.00 \\
\hline 1.17 & 0.17 & 0.76 & 0.66 & 0.33 & 0.00 & 0.67 & 0.33 & 0.50 \\
\hline 7.17 & 4.14 & 4.74 & 1.99 & 2.32 & 7.15 & 3.50 & 2.00 & 3.50 \\
\hline 4.00 & 4.64 & 4.59 & 5.64 & 6.62 & 7.32 & 7.33 & 7.65 & 12.33 \\
\hline 0.00 & 0.00 & 0.00 & 0.00 & 0.00 & 0.00 & 0.00 & 0.00 & 0.00 \\
\hline 0.00 & 0.00 & 0.15 & 0.00 & 0.00 & 0.33 & 0.00 & 0.33 & 0.00 \\
\hline 0.00 & 0.00 & 0.00 & 0.00 & 0.00 & 0.00 & 0.00 & 0.00 & 0.00 \\
\hline 0.83 & 0.00 & 0.61 & 0.00 & 0.00 & 1.66 & 0.00 & 0.00 & 0.00 \\
\hline 0.00 & 0.00 & 0.00 & 0.00 & 0.00 & 0.00 & 0.00 & 0.00 & 0.00 \\
\hline 0.00 & 0.33 & 0.00 & 0.00 & 0.00 & 0.00 & 0.00 & 0.00 & 0.00 \\
\hline 0.00 & 0.00 & 0.00 & 0.00 & 0.00 & 0.00 & 0.00 & 0.00 & 0.00 \\
\hline 0.00 & 0.00 & 0.31 & 0.00 & 0.00 & 0.00 & 0.00 & 0.00 & 0.33 \\
\hline 0.33 & 1.32 & 1.22 & 4.31 & 3.97 & 3.00 & 2.67 & 1.66 & 3.00 \\
\hline 0.00 & 0.00 & 0.00 & 0.00 & 0.00 & 0.00 & 0.00 & 0.00 & 0.00 \\
\hline 0.00 & 0.00 & 0.00 & 0.00 & 0.00 & 0.00 & 0.00 & 0.00 & 0.00 \\
\hline 0.00 & 0.00 & 0.00 & 0.00 & 0.33 & 0.00 & 0.33 & 0.00 & 0.33 \\
\hline 0.00 & 0.00 & 0.00 & 0.00 & 0.00 & 0.00 & 0.00 & 0.00 & 0.00 \\
\hline 0.00 & 0.00 & 0.00 & 0.00 & 0.33 & 0.33 & 0.00 & 0.00 & 0.00 \\
\hline 0.00 & 0.00 & 0.00 & 0.00 & 0.00 & 0.00 & 0.00 & 0.00 & 0.00 \\
\hline 1.33 & 1.99 & 1.22 & 1.66 & 0.99 & 1.66 & 0.67 & 1.00 & 6.00 \\
\hline 0.33 & 0.33 & 3.36 & 0.66 & 3.64 & 1.33 & 1.33 & 3.66 & 2.33 \\
\hline 0.00 & 0.00 & 0.00 & 0.00 & 0.00 & 0.67 & 0.67 & 0.33 & 0.67 \\
\hline
\end{tabular}




$\begin{array}{rrrrrrrrr}59.67 & 59.27 & 44.95 & 38.47 & 40.73 & 42.93 & 33.33 & 35.94 & 36.33 \\ 0.00 & 0.00 & 0.61 & 8.62 & 0.00 & 0.00 & 0.00 & 0.00 & 0.00 \\ 0.00 & 0.00 & 0.31 & 0.00 & 0.00 & 0.00 & 0.00 & 0.33 & 0.00 \\ 0.00 & 0.66 & 0.00 & 0.66 & 0.33 & 0.00 & 0.33 & 0.00 & 0.00 \\ 6.17 & 7.62 & 8.10 & 9.95 & 5.63 & 13.31 & 19.67 & 17.64 & 3.17 \\ 0.00 & 0.00 & 0.00 & 0.33 & 0.00 & 1.00 & 0.00 & 0.33 & 0.00 \\ 0.33 & 0.00 & 0.00 & 0.00 & 0.33 & 0.00 & 0.00 & 0.00 & 0.00 \\ 0.67 & 0.99 & 2.45 & 2.65 & 2.98 & 1.66 & 2.67 & 1.00 & 2.00 \\ 4.00 & 1.66 & 3.36 & 5.64 & 14.24 & 1.66 & 5.67 & 1.66 & 10.00 \\ 0.00 & 0.00 & 0.00 & 0.00 & 0.00 & 0.00 & 0.00 & 0.00 & 0.00 \\ 0.33 & 0.33 & 0.00 & 0.33 & 0.33 & 0.00 & 0.00 & 0.67 & 0.67 \\ 2.00 & 1.99 & 3.36 & 4.64 & 2.98 & 0.67 & 2.67 & 3.33 & 1.67 \\ 0.00 & 0.00 & 0.00 & 0.00 & 0.00 & 0.00 & 0.00 & 0.00 & 0.00 \\ 0.00 & 0.00 & 0.00 & 0.00 & 0.00 & 0.00 & 0.00 & 0.33 & 0.00\end{array}$




\begin{tabular}{|c|c|c|c|c|c|c|c|c|}
\hline 46.07 & 46.27 & 46.36 & 46.66 & 46.86 & 47.07 & 47.27 & 47.4 & 47.6 \\
\hline 7215 & 7232 & 7240 & 7266 & 7283 & 7301 & 7319 & 7330 & 7347 \\
\hline 0.00 & 0.00 & 0.00 & 0.00 & 0.00 & 0.00 & 0.00 & 0.00 & 0.00 \\
\hline 0.00 & 0.67 & 0.00 & 0.50 & 0.00 & 0.17 & 0.17 & 0.00 & 0.00 \\
\hline 0.00 & 0.00 & 0.00 & 0.00 & 0.00 & 0.00 & 0.00 & 0.00 & 0.00 \\
\hline 0.00 & 0.00 & 0.50 & 0.33 & 0.67 & 1.66 & 0.00 & 0.00 & 0.33 \\
\hline 0.33 & 0.67 & 0.33 & 0.00 & 2.50 & 2.66 & 0.33 & 1.66 & 0.66 \\
\hline 0.17 & 0.00 & 0.00 & 0.00 & 0.00 & 0.00 & 0.00 & 0.00 & 0.00 \\
\hline 0.33 & 0.00 & 0.00 & 0.67 & 1.00 & 0.50 & 0.33 & 0.66 & 1.65 \\
\hline 0.33 & 0.33 & 1.33 & 0.00 & 0.00 & 0.83 & 0.50 & 0.00 & 0.66 \\
\hline 0.00 & 0.00 & 0.00 & 0.00 & 0.00 & 0.00 & 0.00 & 0.00 & 0.00 \\
\hline 0.83 & 1.16 & 2.00 & 3.00 & 1.83 & 1.33 & 2.50 & 2.82 & 2.81 \\
\hline 2.33 & 2.00 & 0.83 & 2.50 & 0.83 & 2.16 & 3.50 & 2.49 & 5.12 \\
\hline 0.00 & 0.00 & 0.00 & 0.00 & 0.00 & 0.00 & 0.00 & 0.00 & 0.00 \\
\hline 0.00 & 0.00 & 0.00 & 0.00 & 0.00 & 0.00 & 0.00 & 0.00 & 0.00 \\
\hline 0.00 & 0.00 & 0.00 & 0.00 & 0.33 & 0.67 & 0.33 & 0.00 & 0.33 \\
\hline 1.33 & 1.00 & 0.00 & 1.00 & 0.33 & 0.33 & 0.67 & 0.00 & 0.66 \\
\hline 0.33 & 0.00 & 0.33 & 0.00 & 0.00 & 0.00 & 0.00 & 0.00 & 0.00 \\
\hline 0.00 & 0.00 & 0.00 & 0.33 & 0.17 & 0.33 & 0.33 & 0.00 & 0.00 \\
\hline 2.50 & 2.16 & 2.50 & 5.16 & 2.66 & 3.83 & 5.00 & 4.15 & 2.64 \\
\hline 1.33 & 3.33 & 4.66 & 3.00 & 1.00 & 2.00 & 1.33 & 4.32 & 1.32 \\
\hline 0.50 & 0.33 & 0.50 & 0.33 & 0.00 & 0.33 & 0.00 & 0.00 & 0.00 \\
\hline 0.33 & 1.00 & 0.00 & 0.33 & 0.00 & 0.67 & 0.00 & 1.00 & 0.66 \\
\hline 0.33 & 0.67 & 0.00 & 0.00 & 1.33 & 0.00 & 0.17 & 0.00 & 0.00 \\
\hline 0.67 & 0.00 & 0.00 & 0.00 & 1.00 & 0.00 & 0.67 & 0.66 & 0.00 \\
\hline 0.00 & 0.00 & 0.00 & 0.17 & 0.00 & 0.00 & 0.00 & 0.00 & 0.00 \\
\hline 0.17 & 0.50 & 0.00 & 0.33 & 0.33 & 1.16 & 1.00 & 0.17 & 1.65 \\
\hline 1.00 & 0.67 & 1.50 & 0.00 & 0.17 & 0.33 & 0.50 & 0.00 & 0.00 \\
\hline 0.00 & 0.00 & 0.00 & 0.00 & 0.00 & 0.33 & 0.00 & 0.00 & 0.50 \\
\hline 0.00 & 0.33 & 0.50 & 0.00 & 0.17 & 0.00 & 0.17 & 0.33 & 0.00 \\
\hline 3.00 & 2.83 & 1.66 & 2.66 & 1.16 & 1.50 & 2.33 & 0.50 & 3.14 \\
\hline 13.00 & 17.97 & 8.32 & 13.31 & 9.65 & 19.30 & 18.00 & 18.94 & 20.13 \\
\hline 0.00 & 0.67 & 0.00 & 0.33 & 0.00 & 0.00 & 0.00 & 0.00 & 0.33 \\
\hline 0.00 & 0.00 & 0.00 & 0.00 & 0.33 & 0.00 & 0.33 & 0.33 & 0.00 \\
\hline 0.67 & 0.00 & 0.67 & 0.00 & 0.00 & 0.00 & 0.00 & 0.00 & 0.00 \\
\hline 0.00 & 0.00 & 0.00 & 0.33 & 0.00 & 0.00 & 0.00 & 0.00 & 0.00 \\
\hline 0.00 & 0.00 & 0.00 & 0.00 & 0.00 & 0.00 & 0.00 & 0.00 & 0.00 \\
\hline 0.33 & 0.00 & 0.00 & 0.33 & 0.00 & 0.00 & 0.33 & 0.00 & 1.65 \\
\hline 0.00 & 0.00 & 0.33 & 0.33 & 0.00 & 0.33 & 0.00 & 0.00 & 0.33 \\
\hline 0.00 & 0.67 & 0.33 & 1.00 & 0.00 & 0.33 & 0.33 & 0.00 & 1.32 \\
\hline 2.00 & 5.99 & 3.00 & 3.00 & 7.65 & 4.33 & 4.67 & 4.32 & 5.28 \\
\hline 0.00 & 0.00 & 0.00 & 0.00 & 0.00 & 0.00 & 0.00 & 0.00 & 0.00 \\
\hline 0.00 & 0.00 & 0.00 & 0.67 & 0.00 & 0.33 & 0.67 & 0.00 & 0.33 \\
\hline 0.67 & 0.00 & 0.00 & 0.00 & 0.00 & 0.33 & 0.00 & 0.00 & 0.66 \\
\hline 0.00 & 0.00 & 0.00 & 0.00 & 0.00 & 0.00 & 0.00 & 0.00 & 0.33 \\
\hline 0.00 & 0.33 & 0.33 & 0.00 & 0.33 & 0.00 & 0.00 & 0.33 & 0.00 \\
\hline 0.00 & 0.00 & 0.00 & 0.00 & 0.67 & 0.33 & 0.33 & 0.66 & 0.33 \\
\hline 3.00 & 1.66 & 1.66 & 3.33 & 4.66 & 2.00 & 2.00 & 0.66 & 0.33 \\
\hline 1.00 & 0.67 & 2.00 & 2.00 & 1.33 & 6.66 & 2.67 & 6.98 & 3.30 \\
\hline 4.67 & 2.00 & 0.67 & 2.33 & 0.00 & 3.33 & 4.33 & 2.99 & 0.99 \\
\hline
\end{tabular}




$\begin{array}{rrrrrrrrr}16.00 & 26.62 & 24.29 & 19.30 & 13.98 & 8.65 & 26.33 & 13.95 & 11.88 \\ 0.00 & 0.33 & 2.00 & 0.00 & 0.00 & 0.00 & 0.00 & 0.00 & 0.00 \\ 0.00 & 0.00 & 0.00 & 0.00 & 0.00 & 0.00 & 0.00 & 0.33 & 0.00 \\ 0.00 & 0.00 & 0.00 & 0.00 & 0.00 & 0.33 & 0.33 & 0.00 & 0.00 \\ 16.83 & 8.82 & 19.80 & 5.66 & 24.96 & 13.98 & 5.33 & 14.45 & 2.81 \\ 0.00 & 0.00 & 0.00 & 0.00 & 0.67 & 0.00 & 0.00 & 0.00 & 3.96 \\ 0.00 & 0.00 & 0.00 & 0.00 & 0.00 & 0.00 & 0.00 & 0.33 & 0.00 \\ 5.67 & 0.67 & 4.99 & 3.99 & 3.00 & 3.99 & 3.00 & 5.65 & 1.98 \\ 9.33 & 0.33 & 3.66 & 3.00 & 1.33 & 1.00 & 0.33 & 1.33 & 0.66 \\ 0.00 & 0.00 & 0.00 & 0.00 & 0.33 & 0.00 & 0.00 & 0.33 & 0.00 \\ 0.33 & 0.00 & 0.33 & 0.00 & 0.00 & 0.33 & 0.67 & 0.00 & 0.66 \\ 2.00 & 2.33 & 2.66 & 6.66 & 2.33 & 0.67 & 0.33 & 1.00 & 1.65 \\ 0.00 & 0.00 & 0.33 & 0.00 & 0.00 & 0.00 & 0.00 & 0.00 & 2.64 \\ 0.00 & 0.00 & 0.00 & 0.00 & 0.33 & 0.00 & 1.00 & 0.00 & 0.33\end{array}$




\begin{tabular}{|c|c|c|c|c|c|c|c|c|}
\hline 47.71 & 47.91 & 48.11 & 48.31 & 48.46 & 48.55 & 48.72 & 48.99 & $\begin{array}{r}49.2 \\
7485.887\end{array}$ \\
\hline 7357 & 7374 & 7391 & 7409 & 7422 & 7429 & 7444.24 & 7467.666 & 7485.887 \\
\hline 0.00 & 0.00 & 0.00 & 0.00 & 0.00 & 0.00 & 0.00 & 0.00 & 0.00 \\
\hline 0.83 & 0.00 & 0.50 & 1.17 & 0.33 & 0.33 & 0.00 & 0.00 & 0.33 \\
\hline 0.00 & 0.00 & 0.00 & 0.00 & 0.66 & 0.00 & 0.00 & 0.00 & 0.00 \\
\hline 1.33 & 0.00 & 0.00 & 0.00 & 0.00 & 0.17 & 0.00 & 0.00 & 0.33 \\
\hline 1.67 & 0.33 & 0.00 & 2.33 & 0.33 & 0.66 & 0.00 & 0.00 & 0.00 \\
\hline 0.00 & 0.00 & 0.33 & 0.00 & 0.00 & 0.00 & 0.00 & 0.00 & 0.00 \\
\hline 0.00 & 1.00 & 1.00 & 0.33 & 1.32 & 1.00 & 0.00 & 11.65 & 7.65 \\
\hline 1.67 & 4.49 & 4.49 & 3.83 & 0.99 & 1.83 & 8.65 & 11.98 & 12.65 \\
\hline 0.00 & 0.00 & 0.33 & 0.00 & 0.00 & 0.00 & 0.33 & 0.00 & 1.00 \\
\hline 3.00 & 2.83 & 2.33 & 1.00 & 1.32 & 1.33 & 1.33 & 3.33 & 2.33 \\
\hline 6.00 & 6.16 & 3.33 & 7.00 & 1.98 & 3.82 & 2.16 & 3.66 & 2.66 \\
\hline 0.00 & 0.00 & 0.00 & 0.00 & 0.00 & 0.00 & 0.00 & 0.33 & 0.00 \\
\hline 0.00 & 0.00 & 0.33 & 0.00 & 0.00 & 0.00 & 5.32 & 3.00 & 1.33 \\
\hline 0.00 & 1.33 & 0.33 & 0.00 & 0.00 & 0.00 & 0.33 & 2.00 & 0.00 \\
\hline 0.00 & 1.33 & 0.33 & 0.83 & 0.66 & 1.66 & 2.16 & 2.16 & 7.49 \\
\hline 0.67 & 0.00 & 0.00 & 0.00 & 0.00 & 0.00 & 1.00 & 0.00 & 0.00 \\
\hline 0.00 & 0.00 & 0.00 & 0.33 & 0.33 & 0.00 & 0.33 & 4.66 & 1.33 \\
\hline 1.33 & 2.16 & 0.83 & 0.17 & 0.99 & 0.50 & 0.33 & 0.17 & 0.17 \\
\hline 1.33 & 4.99 & 2.33 & 3.33 & 0.33 & 2.66 & 0.00 & 0.67 & 0.67 \\
\hline 0.33 & 1.16 & 0.00 & 0.00 & 0.00 & 0.00 & 0.50 & 0.00 & 0.00 \\
\hline 2.33 & 1.50 & 1.00 & 0.67 & 0.00 & 4.32 & 0.83 & 3.33 & 0.83 \\
\hline 0.33 & 0.00 & 0.33 & 0.00 & 0.00 & 0.00 & 0.00 & 1.00 & 2.50 \\
\hline 0.00 & 0.67 & 0.00 & 0.00 & 0.33 & 1.33 & 0.00 & 1.33 & 0.00 \\
\hline 0.00 & 0.00 & 1.66 & 0.67 & 0.00 & 0.17 & 3.00 & 0.83 & 1.83 \\
\hline 0.00 & 2.00 & 0.67 & 0.67 & 0.33 & 2.33 & 0.00 & 0.00 & 0.00 \\
\hline 0.17 & 0.67 & 0.17 & 2.17 & 1.82 & 1.99 & 0.00 & 0.33 & 0.17 \\
\hline 0.33 & 0.00 & 1.66 & 2.33 & 0.00 & 1.66 & 2.83 & 2.66 & 1.00 \\
\hline 0.17 & 0.83 & 0.50 & 0.33 & 0.83 & 0.00 & 0.50 & 0.17 & 0.17 \\
\hline 0.67 & 0.50 & 0.00 & 0.33 & 1.98 & 1.16 & 0.00 & 0.33 & 0.83 \\
\hline 9.00 & 7.65 & 0.00 & 1.67 & 7.93 & 2.33 & 0.00 & 1.33 & 0.33 \\
\hline 0.00 & 0.00 & 0.00 & 0.00 & 0.00 & 0.00 & 3.00 & 0.00 & 0.17 \\
\hline 0.00 & 0.00 & 0.33 & 0.00 & 0.00 & 0.00 & 0.00 & 0.00 & 0.00 \\
\hline 0.00 & 0.33 & 0.00 & 0.00 & 0.66 & 0.66 & 0.00 & 0.00 & 0.67 \\
\hline 0.00 & 0.00 & 0.00 & 0.00 & 0.00 & 0.33 & 0.00 & 0.00 & 0.00 \\
\hline 0.00 & 0.00 & 0.00 & 0.00 & 0.00 & 0.00 & 0.00 & 0.00 & 0.00 \\
\hline 0.00 & 0.00 & 0.33 & 0.00 & 0.33 & 0.00 & 0.00 & 0.33 & 0.00 \\
\hline 0.33 & 0.00 & 0.00 & 0.67 & 0.00 & 0.00 & 0.33 & 0.00 & 0.00 \\
\hline 0.67 & 1.00 & 0.67 & 3.00 & 0.33 & 0.66 & 1.33 & 0.67 & 0.33 \\
\hline 9.67 & 4.66 & 17.30 & 8.33 & 2.31 & 9.30 & 12.31 & 5.66 & 2.00 \\
\hline 0.00 & 0.00 & 0.00 & 0.00 & 0.00 & 0.00 & 0.00 & 0.00 & 3.00 \\
\hline 0.33 & 0.00 & 0.00 & 0.00 & 0.00 & 0.33 & 0.67 & 1.66 & 6.32 \\
\hline 0.67 & 0.33 & 1.00 & 1.00 & 0.00 & 0.33 & 0.00 & 0.00 & 2.66 \\
\hline 0.00 & 0.00 & 0.00 & 0.00 & 0.00 & 0.00 & 0.00 & 0.00 & 0.00 \\
\hline 0.00 & 0.67 & 0.33 & 0.00 & 0.33 & 0.33 & 0.67 & 0.67 & 0.00 \\
\hline 0.33 & 0.00 & 0.00 & 1.33 & 0.00 & 0.00 & 0.33 & 0.00 & 0.00 \\
\hline 0.67 & 2.33 & 1.33 & 0.67 & 1.32 & 1.33 & 1.00 & 2.66 & 0.00 \\
\hline 7.33 & 6.32 & 26.29 & 22.67 & 5.29 & 11.96 & 12.65 & 0.33 & 2.66 \\
\hline 9.67 & 4.99 & 4.33 & 2.67 & 0.33 & 1.99 & 2.00 & 0.33 & 0.33 \\
\hline
\end{tabular}




$\begin{array}{rrrrrrrrr}22.67 & 12.98 & 1.33 & 3.67 & 40.00 & 16.61 & 4.66 & 9.65 & 7.65 \\ 0.00 & 0.00 & 0.33 & 0.00 & 0.00 & 0.33 & 0.67 & 0.00 & 0.00 \\ 0.00 & 0.00 & 0.00 & 0.00 & 0.00 & 0.00 & 0.00 & 0.00 & 0.00 \\ 0.00 & 0.00 & 0.33 & 0.00 & 0.00 & 0.33 & 0.00 & 0.00 & 0.00 \\ 2.50 & 0.50 & 0.17 & 0.00 & 4.30 & 8.97 & 0.33 & 1.50 & 1.50 \\ 0.00 & 0.33 & 0.00 & 0.00 & 0.66 & 0.00 & 0.00 & 0.00 & 0.00 \\ 0.00 & 0.00 & 0.00 & 0.00 & 0.33 & 0.00 & 0.00 & 0.00 & 0.00 \\ 1.33 & 1.00 & 0.33 & 2.33 & 1.65 & 0.66 & 0.67 & 0.00 & 0.33 \\ 1.33 & 1.00 & 0.33 & 0.33 & 0.66 & 0.00 & 0.00 & 0.00 & 0.00 \\ 0.00 & 0.00 & 0.00 & 0.00 & 0.66 & 0.00 & 0.33 & 0.00 & 0.00 \\ 0.00 & 0.00 & 0.33 & 0.33 & 0.00 & 0.66 & 0.00 & 0.00 & 0.00 \\ 1.33 & 0.00 & 0.00 & 0.00 & 4.63 & 0.33 & 0.33 & 1.00 & 0.00 \\ 0.00 & 0.67 & 0.00 & 2.33 & 0.00 & 0.00 & 1.00 & 0.00 & 1.66 \\ 0.00 & 0.33 & 0.00 & 0.00 & 2.64 & 0.00 & 0.00 & 0.00 & 0.33\end{array}$




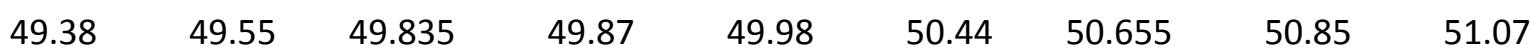
\begin{tabular}{rrrrrrrrr}
7501.505 & 7516.255 & 7540.984 & 7544.02 & 7553.565 & 7593.477 & 7612.132 & 7629.051 & 7648.14 \\
\hline 0.00 & 0.00 & 1.96 & 0.00 & 0.00 & 0.00 & 0.00 & 0.00 & 0.83
\end{tabular}

\begin{tabular}{|c|c|c|c|c|c|c|c|c|}
\hline 0.00 & 0.00 & 1.96 & 0.00 & 0.00 & 0.00 & 0.00 & 0.00 & 0.83 \\
\hline 0.65 & 0.83 & 0.82 & 1.15 & 0.82 & 0.00 & 0.00 & 0.00 & 0.00 \\
\hline 0.00 & 0.00 & 0.65 & 0.00 & 0.00 & 0.00 & 0.00 & 0.00 & 0.00 \\
\hline 0.00 & 0.33 & 0.00 & 0.33 & 0.00 & 2.83 & 3.83 & 0.67 & 0.99 \\
\hline 1.30 & 0.99 & 0.00 & 0.99 & 0.99 & 0.00 & 4.67 & 1.33 & 0.99 \\
\hline 0.16 & 0.17 & 2.29 & 2.80 & 0.82 & 6.16 & 6.00 & 2.83 & 1.49 \\
\hline 7.97 & 5.45 & 5.24 & 2.80 & 1.15 & 0.67 & 2.67 & 1.33 & 4.14 \\
\hline 1.95 & 0.99 & 0.16 & 0.33 & 0.00 & 0.00 & 0.33 & 0.50 & 0.17 \\
\hline 0.33 & 0.33 & 0.16 & 8.57 & 1.98 & 0.00 & 3.33 & 0.00 & 0.00 \\
\hline 2.76 & 0.33 & 0.16 & 0.00 & 0.00 & 0.00 & 1.00 & 0.00 & 0.17 \\
\hline 0.81 & 0.66 & 0.49 & 0.99 & 0.00 & 0.33 & 0.50 & 0.00 & 0.00 \\
\hline 0.00 & 0.00 & 1.31 & 0.00 & 0.00 & 0.00 & 0.00 & 0.00 & 0.99 \\
\hline 0.49 & 0.00 & 0.00 & 0.00 & 0.16 & 0.67 & 0.00 & 0.00 & 0.00 \\
\hline 0.65 & 1.82 & 0.49 & 0.16 & 0.33 & 1.33 & 2.33 & 0.33 & 0.50 \\
\hline 13.17 & 7.77 & 3.44 & 3.29 & 5.60 & 6.99 & 4.67 & 1.00 & 2.15 \\
\hline 0.33 & 0.66 & 1.15 & 0.00 & 0.33 & 0.00 & 0.00 & 0.00 & 0.00 \\
\hline 2.60 & 0.33 & 0.33 & 0.00 & 0.00 & 0.33 & 0.00 & 0.00 & 0.00 \\
\hline 0.00 & 0.00 & 0.33 & 0.00 & 0.00 & 0.00 & 0.00 & 0.00 & 0.00 \\
\hline 1.63 & 0.99 & 2.62 & 0.00 & 0.00 & 0.00 & 0.00 & 0.00 & 0.00 \\
\hline 0.00 & 0.00 & 2.45 & 0.00 & 0.00 & 0.00 & 0.00 & 0.00 & 0.00 \\
\hline 0.33 & 0.00 & 0.00 & 0.33 & 0.00 & 0.00 & 0.00 & 0.00 & 0.00 \\
\hline 7.80 & 1.32 & 0.00 & 0.99 & 2.31 & 1.00 & 0.83 & 3.00 & 1.16 \\
\hline 0.00 & 1.98 & 0.00 & 0.99 & 0.99 & 2.66 & 1.33 & 1.66 & 0.99 \\
\hline 3.74 & 0.83 & 0.00 & 0.16 & 0.00 & 0.50 & 0.00 & 0.00 & 0.00 \\
\hline 0.00 & 0.00 & 0.00 & 0.00 & 0.00 & 0.00 & 0.00 & 0.00 & 0.00 \\
\hline 0.00 & 0.00 & 0.00 & 0.00 & 0.00 & 0.00 & 0.00 & 0.00 & 0.00 \\
\hline 1.63 & 0.00 & 0.00 & 0.00 & 0.00 & 0.00 & 0.00 & 0.00 & 0.00 \\
\hline 0.00 & 0.00 & 0.00 & 0.00 & 0.00 & 0.00 & 0.00 & 0.00 & 0.00 \\
\hline 0.00 & 0.33 & 0.00 & 0.00 & 0.00 & 0.00 & 0.00 & 0.00 & 0.00 \\
\hline 0.00 & 0.33 & 0.33 & 0.33 & 0.00 & 0.00 & 0.00 & 0.00 & 0.00 \\
\hline 0.00 & 0.00 & 0.33 & 0.00 & 0.00 & 0.00 & 0.00 & 0.00 & 0.00 \\
\hline 0.00 & 0.00 & 0.00 & 0.00 & 0.00 & 0.00 & 0.00 & 0.00 & 0.00 \\
\hline 0.00 & 0.00 & 0.65 & 0.00 & 0.00 & 0.00 & 0.00 & 0.00 & 0.00 \\
\hline 0.33 & 0.00 & 0.00 & 0.00 & 0.00 & 0.00 & 0.00 & 0.00 & 0.00 \\
\hline 0.00 & 0.00 & 0.00 & 0.00 & 0.33 & 0.00 & 0.00 & 0.00 & 0.00 \\
\hline 0.33 & 13.88 & 1.96 & 0.99 & 4.28 & 3.66 & 6.33 & 2.00 & 3.97 \\
\hline 0.00 & 5.62 & 2.62 & 3.29 & 5.60 & 2.33 & 3.33 & 2.00 & 5.30 \\
\hline 0.65 & 20.17 & 1.64 & 19.11 & 25.70 & 23.29 & 5.33 & 57.90 & 43.38 \\
\hline 4.55 & 0.99 & 5.24 & 0.33 & 0.33 & 0.67 & 0.00 & 1.33 & 0.66 \\
\hline 2.60 & 2.64 & 0.33 & 1.32 & 2.31 & 2.00 & 4.67 & 1.66 & 0.99 \\
\hline 0.98 & 5.62 & 6.87 & 8.57 & 5.27 & 7.65 & 5.67 & 1.33 & 1.99 \\
\hline 1.95 & 5.29 & 7.20 & 4.28 & 5.60 & 4.33 & 4.00 & 7.65 & 3.31 \\
\hline 3.58 & 0.66 & 1.96 & 1.65 & 1.98 & 0.33 & 0.33 & 1.66 & 1.99 \\
\hline 0.65 & 3.97 & 20.62 & 23.39 & 20.76 & 17.64 & 27.00 & 3.99 & 7.28 \\
\hline 4.23 & 1.98 & 7.86 & 1.98 & 5.60 & 2.66 & 0.00 & 3.00 & 3.64 \\
\hline 0.00 & 0.00 & 0.00 & 0.00 & 0.00 & 0.00 & 0.33 & 0.00 & 0.00 \\
\hline 0.00 & 0.66 & 0.98 & 0.66 & 0.00 & 0.00 & 0.00 & 0.00 & 0.00 \\
\hline 0.00 & 0.00 & 0.00 & 0.00 & 0.00 & 0.00 & 0.00 & 0.00 & 0.0 \\
\hline
\end{tabular}




$\begin{array}{lllllllll}1.63 & 3.31 & 1.64 & 1.65 & 0.00 & 0.67 & 0.33 & 0.33 & 1.66 \\ 0.00 & 0.00 & 0.00 & 0.00 & 0.00 & 0.00 & 0.00 & 0.00 & 0.00 \\ 0.00 & 0.00 & 0.00 & 0.00 & 0.00 & 0.00 & 0.00 & 0.00 & 0.00 \\ 0.00 & 0.00 & 0.00 & 0.00 & 0.00 & 0.00 & 0.00 & 0.00 & 0.00 \\ 0.00 & 0.17 & 0.65 & 0.33 & 0.00 & 0.00 & 0.17 & 0.17 & 0.00 \\ 0.00 & 0.00 & 0.00 & 0.00 & 0.00 & 0.00 & 0.00 & 0.00 & 0.00 \\ 0.00 & 0.00 & 0.00 & 0.00 & 0.00 & 0.00 & 0.00 & 0.00 & 0.00 \\ 0.00 & 0.00 & 0.00 & 0.00 & 0.00 & 0.00 & 0.00 & 0.00 & 0.00 \\ 0.00 & 0.00 & 0.00 & 0.00 & 0.00 & 0.00 & 0.00 & 0.00 & 0.00 \\ 0.00 & 0.00 & 0.00 & 0.00 & 0.00 & 0.00 & 0.00 & 0.00 & 0.00 \\ 0.00 & 0.00 & 0.00 & 0.00 & 0.00 & 0.00 & 0.00 & 0.00 & 0.00 \\ 0.00 & 0.00 & 0.33 & 0.00 & 0.00 & 0.00 & 0.00 & 0.00 & 0.00 \\ 0.49 & 0.00 & 0.00 & 0.00 & 0.00 & 0.00 & 0.00 & 0.00 & 0.00 \\ 0.00 & 0.00 & 0.00 & 0.00 & 0.00 & 0.00 & 0.00 & 0.00 & 0.00\end{array}$




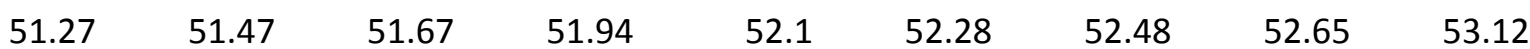

\begin{tabular}{rrrrrrrrr}
7665.493 & 7682.846 & 7700.199 & 7723.626 & 7737.509 & 7753.126 & 7770.48 & 7785.23 & 7826.01 \\
\hline
\end{tabular}

$0.00 \quad 1.33$

$0.50 \quad 0.00$

0.00

0.00

0.66

1.66

0.00

0.33

0.67

$0.00 \quad 0.00$

0.00

0.83

0.33

0.99

1.33

0.33

0.00

2.66

1.00

0.00

0.00

0.00

0.00

0.00

0.00

0.65

0.33

2.33

0.65

1.82

2.49

1.98

0.83

0.00

0.00

$2.66 \quad 0.83$

1.31

0.99

2.49

0.99

0.66

0.33

1.80

$\begin{array}{ll}0.83 & 2.00\end{array}$

1.63

0.66

0.83

0.49

2.66

4.17

0.00

$1.33 \quad 1.17$

0.00

3.31

3.98

6.59

1.99

6.17

3.76

$3.00 \quad 0.00$

0.00

0.33

1.49

0.33

0.66

0.00

1.31

$0.00 \quad 0.33$

0.00

0.00

0.00

0.00

0.00

0.00

0.00

$1.00 \quad 1.83$

0.33

$1.33 \quad 0.00$

0.00

0.17

0.33

0.00

0.00

0.00

0.00

$0.00 \quad 0.00$

0.65

0.17

0.00

0.00

0.33

0.00

0.00

0.33

0.33

0.00

0.66

0.66

0.00

0.00

0.00

$4.83 \quad 3.00$

2.12

0.50

0.17

0.00

0.00

0.00

0.00

$0.00 \quad 0.00$

0.00

1.32

0.33

0.33

0.00

0.00

0.00

$0.00 \quad 0.00$

0.00

0.99

8.79

5.60

10.13

1.17

0.33

$0.00 \quad 0.33$

0.33

2.66

0.00

0.00

0.66

1.32

1.00

0.67

12.93

$0.00 \quad 0.00$

3.27

$0.00 \quad 0.00$

0.00

$1.66 \quad 2.33$

4.25

$3.66 \quad 1.00$

0.00

0.00

0.67

0.00

0.00

0.00

$0.00 \quad 0.33$

0.00

$0.00 \quad 0.00$

0.00

0.00

$0.00 \quad 0.00$

0.00

0.00

0.00

1.31

0.33

0.00

0.33

$0.00 \quad 0.00$

0.00

$0.00 \quad 0.00$

$0.00 \quad 1.33$

0.00

0.00

$0.00 \quad 0.00$

0.00

0.00

0.33

0.16

0.00

0.00

0.00

1.32

0.00

0.00

0.00

0.00

0.00

0.00

1.99

0.99

0.66

0.33

0.00

$$
0.00
$$

0.00

0.00

0.00

4.50

0.00

2.32

2.65

0.00

0.66

0.33

0.00

\subsection{6}

2.99

4.12

1.50

2.33

0.00

0.00

0.00

5.77

3.99

0.00

2.29

\subsection{0}

0.00

0.00

0.00

0.17

0.33

$0.00 \quad 0.00$

0.00

0.00

0.00

0.00

0.00

0.00

0.00

$2.33 \quad 2.33$

0.33

0.00

0.66

0.00

0.00

0.00

0.00

$3.99 \quad 4.00$

8.17

0.00

0.00

2.31

1.00

0.00

0.00

$39.93 \quad 34.33$

40.52

0.00

0.00

0.00

0.00

0.00

0.00

\subsection{0}

0.00

0.00

0.00

0.33

0.00

$$
0.00
$$

0.00

0.66

0.00

0.00

0.00

0.00

0.00

0.00

0.00

0.00

0.00

0.00

0.00

0.00

0.00

0.00

0.00

0.00

0.00

0.00

0.00

0.00

0.00

0.00

0.67

0.00

0.00
2.98

0.00

0.00

0.00

1.00

3.29

2.33 


$\begin{array}{lllllllll}0.33 & 1.67 & 2.61 & 0.66 & 1.33 & 1.32 & 1.99 & 2.00 & 0.00 \\ 0.00 & 0.00 & 0.00 & 0.00 & 0.00 & 0.00 & 0.00 & 0.00 & 0.00 \\ 0.00 & 0.00 & 0.00 & 0.00 & 0.00 & 0.00 & 0.00 & 0.00 & 0.00 \\ 0.00 & 0.00 & 0.00 & 0.00 & 0.00 & 0.00 & 0.00 & 0.00 & 0.00 \\ 0.00 & 0.00 & 0.33 & 0.00 & 0.00 & 0.49 & 0.00 & 2.17 & 0.00 \\ 0.00 & 0.00 & 0.00 & 0.00 & 0.00 & 0.00 & 0.00 & 0.00 & 0.00 \\ 0.00 & 0.00 & 0.00 & 0.00 & 0.00 & 0.00 & 0.00 & 0.00 & 0.00 \\ 0.00 & 0.67 & 0.00 & 0.00 & 0.00 & 0.00 & 0.00 & 1.00 & 0.00 \\ 0.00 & 0.00 & 0.00 & 0.00 & 0.00 & 0.00 & 0.00 & 0.00 & 0.00 \\ 0.00 & 0.00 & 0.00 & 0.00 & 0.00 & 0.00 & 0.00 & 0.00 & 0.00 \\ 0.00 & 0.00 & 0.00 & 0.00 & 0.00 & 0.00 & 0.00 & 0.00 & 0.00 \\ 0.00 & 0.00 & 0.00 & 0.00 & 0.00 & 0.00 & 0.00 & 0.33 & 0.00 \\ 0.00 & 1.33 & 0.00 & 0.00 & 0.00 & 0.66 & 0.00 & 0.00 & 0.00 \\ 0.00 & 0.00 & 0.00 & 0.00 & 0.00 & 0.00 & 0.00 & 0.00 & 0.00\end{array}$


